\title{
EMERGING VOICES: \\ An Analysis of Subarctic Aboriginal Basketry
}

\author{
by
}

Olivia Thornburn, B.A. Hons.

\author{
A thesis submitted to \\ the Faculty of Graduate Studies and Research \\ in partial fulfillment of \\ the requirements for the degree of
}

Master of Arts

Department of Sociology and Anthropology

Carleton University

Ottawa, Ontario

May 12, 2003

Copyright $\odot$ Olivia Thornburn May 12, 2003 


\author{
National Library \\ of Canada \\ Acquisitions and \\ Bibliographic Services \\ 395 Wellington Street \\ Ottawa ON K1A ON4 \\ Canada
}

Bibliothèque nationale

du Canada

Acquisisitons et services bibliographiques

395 , rue Wellington Ottawa ON K1A 0N4 Canada
Your file Votre référence ISBN: 0-612-89065-1 Our file Notre référence ISBN: 0-612-89065-1
The author has granted a nonexclusive licence allowing the National Library of Canada to reproduce, loan, distribute or sell copies of this thesis in microform, paper or electronic formats.

The author retains ownership of the copyright in this thesis. Neither the thesis nor substantial extracts from it may be printed or otherwise reproduced without the author's permission.
L'auteur a accordé une licence non exclusive permettant à la Bibliothèque nationale du Canada de reproduire, prêter, distribuer ou vendre des copies de cette thèse sous la forme de microfiche/film, de reproduction sur papier ou sur format électronique.

L'auteur conserve la propriété du droit d'auteur qui protège cette thèse. $\mathrm{Ni}$ la thèse ni des extraits substantiels de celle-ci ne doivent être imprimés ou aturement reproduits sans son autorisation.
In compliance with the Canadian Privacy Act some supporting forms may have been removed from this dissertation.

While these forms may be included in the document page count, their removal does not represent any loss of content from the dissertation.
Conformément à la loi canadienne sur la protection de la vie privée, quelques formulaires secondaires ont été enlevés de ce manuscrit.

Bien que ces formulaires aient inclus dans la pagination, il n'y aura aucun contenu manquant. 


\begin{abstract}
This thesis presents an empirical comparison and formal stylistic analysis of subarctic Carrier, Algonquin and Montagnais peoples' birch bark basketry collected in the late nineteenth and early twentieth centuries. At the same time, it places the traditional basketry of subarctic aboriginal peoples in the context of its ethnographic history and, in so doing, considers the impacts on this traditional practice as subarctic peoples were forced to adapt from living on the land to post-European economic, social and cultural practices.

To supplement the limited archival and other historical records of the basketry and their makers, the thesis examines the stories of two remaining subarctic basket makers in order to understand how the traditional knowledge of their basketry has so far survived. In addition to capturing these stories and providing a formal classification and stylistic analysis of the basketry contained in the collections of the Canadian Museum of Civilization and the Royal British Columbia Museum, this document extends the knowledge of a form of material culture that was of great importance to the subarctic peoples, and for the first time makes it available to the communities concerned, museums and others.
\end{abstract}




\section{Acknowledgements}

Appreciation and respect is extended to the following British Columbia First Nation basket makers for the honour of speaking with them and for the contribution they have made to the thesis: Madeline Johnny, Central Carrier Sai'k'uz Ts'eke, and Elder, Stony Creek; Bernie McQuary, Central Carrier Nadleh Whuten, Nautley Reserve; Mary Thomas, Interior Salish Secwepemic Neskonlith, and Elder, Salmon Arm; Rena Bolton, Coast Salish Sto:Lo, Terrace; Pauline Joe, Coast Salish Washington State, Duncan; and, Stella Johnny, Nuu-chah-nulth Dididat, Duncan.

Sincere gratitude is extended to my husband, Geoffrey, for his endless support; to my thesis supervisors, Dr. Andrea Laforet and Professor Derek G. Smith for their interest and guidance; and to my friend, Shelagh M'Gonigle for her accommodation. Also acknowledged is Dr. Martha Black of the Royal British Columbia Museum, and the library and archival staff at the Canadian Museum of Civilization, the British Columbia Provincial Archives, and First Nations cultural centres in British Columbia for their cooperation.

This thesis is dedicated to the unnamed Carrier, Algonquin and Montagnais basket makers of the over two hundred baskets studied. 


\section{Table of Contents}

Abstract

Acknowledgements

List of Tables

List of Figures, Maps, and Illustrations

iv

Chapter One Introduction $\quad 1$

Chapter Two Anthropological Approaches to the Study of Basketry 3

$\begin{array}{lll}\text { Chapter Three } & \text { Transitions for Subarctic Aboriginal Basket Makers } & 14\end{array}$

Chapter Four Stylistic Analysis of Birch Bark Basketry $\quad 57$

$\begin{array}{lll}\text { Chapter Five } & \text { Emerging Voices of Basket Makers } & 104\end{array}$

$\begin{array}{lll}\text { Chapter Six } & \text { Conclusion } & 126\end{array}$

Appendix One Tables $\quad 130$

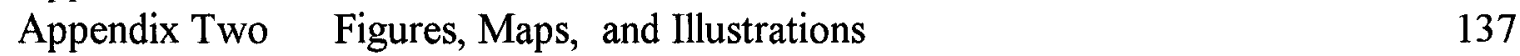

Appendix Three Catalogue of Carrier and Algonquin/Montagnais Basketry 154

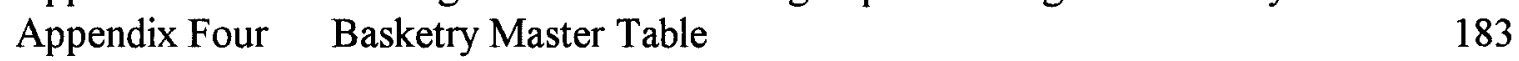

$\begin{array}{ll}\text { Appendix Five } & 201\end{array}$

$\begin{array}{ll}\text { Endnotes } & 212\end{array}$

$\begin{array}{ll}\text { Bibliography } & 221\end{array}$ 


\section{List of Tables}

ONE Number of aboriginal people in Quebec counties

TwO Main Forms and Variations of Algonquin/Montagnais Basketry

THREE Carrier Basketry According to Collector

FouR Carrier Basketry According to Location Collected

FIVE

Acquisition Record for Carrier Basketry

SIX

Algonquin and Montagnais Basketry by Collector, Location and Acquisition Date

SEVEN Forms of Carrier Basketry in the RBCM (RBCM)

EIGHT

Forms of Carrier Basketry in the CMC (VI B)

NINE

Forms of Algonquin/Montagnais Basketry in the CMC (III L, III C) 
List of Figures, Maps, and Illustrations

\section{FIGURES}

$\begin{array}{lll}\text { FIG. } 1 & \text { Beading } & 67\end{array}$

FIG. 2 Carrier. Form A.1. CMC VI B 63. Hazelton. C.M. Barbeau. 70 1920-21.

FIG. 3 Carrier. Form A.2. CMC VI B 138. Stuart Lake. Rev. A.G.

Morice. 1892.

FIG. 4 Carrier. Form A.3. RBCM 11072. Mrs. Melba Menzie Coll'n.

FIG. 5 Carrier Form B.1. CMC VI B 61. Stuart Lake. Rev. A.G..

Morice. 1892.

FIG. 6 Carrier. Form B.2. CMC VI B 116. Hazelton. H.I. Smith. 1925.

FIG. 7 Carrier. Innovation 1. CMC VI B 71. Fort Fraser. Diamond Jenness. 1924.

FIG. 8 Carrier. Innovation 2. RBCM 10530c. Stikine. C.F. Newcombe. Before 1961

FIG. 9 Carrier. Innovation 3. RBCM 14525. Fort Fraser. P.L.MacNair purchase for Museum at K'San Sales, Hazelton. 1974.

FIG. 10 Carrier. Innovation 4. RBCM 18242. Masset. Gift of Henry Edenshaw to Mrs. Dorothy Sherwood. 1919

FIG. 11 Algonquin/ Montagnais. Form C.1. CMC III L 57. Maniwaki. E. Sapir. 1912.

FIG 12 Algonquin/ Montagnais. Form C.2. CMC III L 28-30. Maniwaki. E. Sapir. 1912.

FIG. 13 Algonquin/ Montagnais. Form D. . CMC III L 38. Maniwaki. E. Sapir. 1912. 
FIG. 14 Algonquin/Montagnais. Form D.2 CMC III L 11 and

CMC III L 12. Maniwaki. E. Sapir. 1912

FIG. 15

Algonquin/ Montagnais. Form D.3. CMC III L 117. Lake

88 Temiscaming, and CMC III C 449. Lac St. Jean. F.G. Speck. 1913.

FIG. 16 Algonquin/ Montagnais. Form E.1. CMC III C 17. Pointe Bleue. 1912

FIG. 18

Algonquin. Innovation 2. CMC III L 33. Maniwaki. E. Sapir. 1912.

FIG. 19

Personal choice of decoration by basket maker.

96

FIG. 20

Personal style of Agnes George, and regional identity of salient rim feature.

$\underline{\text { MAPS }}$

MAP $1 \quad$ First Nations of Subarctic Canada

MAP 2 Trading Posts in the Cordillera with approximate dates when they were established and abandoned, when known.

MAP 3

Gitxsan Territories

MAP 4 Dakelh Territories; Central Carrier Communities

MAP 5 Indians of British Columbia: Linguistic Subdivisions

MAP 6

First Nations of British Columbia, 1996.

MAP 7

Bands of the Ottawa valley in the early $17^{\text {th }}$ century and Algonquin reserves in 1970.

MAP $8 \quad$ Montagnais Communities. 


\section{$\underline{\text { ILLUSTRATIONS }}$}

Plate $1 \quad$ Indian Girls at Nulki Lake, 1908. 144

$\begin{array}{lll}\text { Plate } 2 & \text { Indians cleaning salmon at Stuart Lake. }\end{array}$

Plate $3 \quad$ Stoney Creek Indian Church, 1908.

Plate $4 \quad$ Fort St. James Indians at Dominion Day celebrations, 1912.

Plate $5 \quad$ Frank Swannell surveying in Nechako Valley, 1910.

PLATE $6 \quad$ Group photograph of Swannell survey party at Fraser Lake 146 1908.

$\begin{array}{lll}\text { Plate } 7 & \text { Hazelton, R.S. Sargent store and post office. } & 147\end{array}$

$\begin{array}{lll}\text { Plate } 8 & \text { Dr. William Fraser Tolmie and family. } & 147\end{array}$

$\begin{array}{lll}\text { Plate } 9 & \text { Mary of the Incarnation. } & 148\end{array}$

Plate $10 \quad$ The Second Ursuline Order Monastery, Quebec. 148

Plate $11 \quad$ Immaculate Conception. Central medallion embroidered 148 with pure gold, silver and silk thread, by the Ursulines of Quebec XVIIth C.

Plate 12 Examples of end stitching and incised designs on wall fields of baskets: (a) Fig. 202, front and rim. (b) Fig. 202b, short side.

(c) Fig. 203b, short side. (d) Figure 204, birch bark basket.

(e) Fig. 205, birch bark basket.

PLATE 13 (a) Pattern for bark pail and container for berries and women's work materials. (b) Pattern for dish. (c) Pattern for seamless pail or boiler.

PLATE $14 \quad$ Neskolinth Secwepemc Mary Thomas giving birch bark basketry demonstration, 2001.

Plate $15 \quad$ Neskolinth Secwepemc Mary Thomas, 2001.

Plate $16 \quad$ Neskolinth Secwepemc Mary Thomas, Middle Years. 151

Plate $17 \quad$ Neskolinth Secwepemc Mary Thomas, Early Years. 151 
Plate 18 Round Lake Tommy, a Hagwilget Indian

Plate 19 Carrier Wet'suwet'en Adele, Hagwilget ca.1920-21

Plate 20 Carrier Wet'suwet'en Adele, and, Merchant, R.S. Sargent,

153 Hazelton, ca.1920-21 


\section{Chapter One}

\section{INTRODUCTION}

This thesis analyses and compares the formal characteristics of birch bark basketry collected in the early twentieth century from the Carrier, Algonquin and Montagnais peoples of the subarctic region of Canada. Very little information is available in the historical record about the birch bark basketry or the basket makers from these regions. This thesis augments the record and places the basketry more securely in a historical context. Coupled with stylistic analysis, this enables unattributed baskets to be placed with some assurance in their proper historical ethnographic context. Assisted by the perspectives and accounts of certain contemporary basket makers, this analysis allows a richer narrative to be told than has been available to the present.

The primary materials available for the research are 221 subarctic birch bark baskets. They include 148 Carrier baskets, 78 now in the Canadian Museum of Civilization collection and 70 now in the Royal British Columbia Museum collection, and 73 Algonquin/Montagnais baskets now in the Canadian Museum of Civilization.

Ethnographic literature, government records and archival sources provided additional materials. Personal conversations and interviews with aboriginal basket makers, cultural center and museum staff were recorded through field research in British Columbia and Quebec. 
Chapter Two, Approaches to Aboriginal Basketry, discusses anthropological approaches, historical research, regional considerations, and methodologies historically used in the study of basketry. Chapter Three, Transitions for Subarctic Aboriginal Basket Makers, considers the subarctic basket makers' way of life in a sociohistorical context during pre-European and historic times. Aspects of the ethnography and history of each region that have affected basket makers' roles and work are discussed, including issues such as the impact of the European fur trade on traditional trading practices and resulting economic dependencies, loss of lands and resources, and modified social relationships. Chapter Four, Stylistic Analysis of Subarctic Basketry, forms the core of the thesis. It begins with a discussion of the collectors of the birch bark basketry under consideration. Next, the chapter presents a formal stylistic analysis utilizing criteria for primary research in museum collections proposed by Sally McLendon, and the methodology for the study of basketry developed by J.M. Adovasio. The background of stylistic analysis and the scope and criteria of the analysis are explained, leading to a discussion of the results of the analysis, including regional identity and links in basketry.

Chapter Five, Emerging Voices of Aboriginal Basket Makers, considers the importance and meaning of basketry to aboriginal people. Chapter Six, Conclusion, summarizes the goals, themes and results of the thesis, considers some gaps in existing research and offers some suggestions for future research in Canadian aboriginal basketry. Anthropologists have been studying aboriginal basketry for well over a century. The chapter which follows explores this history and the various methodologies employed. 


\section{Chapter Two}

\section{ANTHROPOLOGICAL APPROACHES TO THE STUDY OF BASKETRY}

Between 1884 and 1904, there was a substantial amount of comparative analysis of aboriginal basketry. J.M. Adovasio, (1977: 2-3) provides a complete list. Early writers were Otis Tufton Mason (1838-1908) who wrote Aboriginal Indian Basketry (1904), Samuel A. Barrett (1879-1965) who wrote Pomo Indian Basketry (1908: 133-308) and the collector and popular writer of aboriginal people's material culture, George Wharton James (1858-1923) who wrote Indian Basketry (1909). In their work, these writers focused on basketry as objects. They provided extensive details concerning technique, design, material and uses of basketry. As Berlo noted (1992: 7), James was a student of Mason who helped to fuel the popular passion for collecting basketry, James appeared to have an interest in the basket makers as artists, though he did not record interviews with them or include their stories in his work.

Franz Boas ${ }^{1}$ established his anthropological field research on the Northwest Coast of British Columbia during the 1880 's. Later, while Curator of the Anthropology Department at the American Museum of Natural History (1895-1905), he organized a series of research projects through the Jesup North Pacific Expedition (1887-1902) (Jonaitis 1992: 22).

Ethnographer James A. Teit (1864-1922) worked with Boas during the 1890's. Teit had a broad knowledge and interest in the people of the Interior Salish communities in the interior of British Columbia. He lived among the Nlaka'pamux people at Spences 
Bridge (ca.1905), and was fluent in the Nlaka'pamux language. Teit was hired by Boas in 1894 to make collections for the American Museum of Natural History and to record ethnographic material for the Jesup North Pacific Expedition ${ }^{2}$ (Teit 1900; Jacknis, 144, also see Kew 1993-94; Laforet 1998:200). Teit also worked for Edward Sapir and the Geological Survey of Canada, as well as collecting for museums in New York, Chicago, Ottawa, and Victoria (Jacknis: 1992: 144).

While Boas and Teit were collaborating, Teit wrote a substantial volume of work on the southern British Columbia aboriginal people (Jacknis, 144). Publications included The Thompson Indians of British Columbia (1900), The Shuswap (1905), The Lillooet (1906), and the Salishan Tribes of the Western Plateaus (1930).

Corresponding with his graduate student, Herman K. Haeberlin (1890-1918) and with Teit, Boas requested ethnographic material for his research. Subsequently, under Boas' direction, the results of Haeberlin, Teit, and Helen Roberts' work were published in Coiled Basketry in British Columbia and Surrounding Region (1928: 119-484).

Jacknis noted (1992: 136) that Boas had turned his attention "to issues of cultural change, the integration of culture, and the role of the individual," and away from the focus on traditional design elements of his predecessors such as George Wharton James. According to Schevill (1992: 169), this was an important turning point for research in aboriginal basketry. The focus became not the basketry as objects, but the relationship between the artists and their work. Schevill pointed out that the data were gathered through direct interviews with the basket maker artists, while Berlo noted (1992: 9) that 
Haeberlin "more than anyone else championed the study of the individual artist in tribal society."

Ruth Leah Bunzel, also a student of Boas, had been studying and making pottery under the direction of Pueblo potters in Arizona (1929: 169). She followed Boas' advice applying his methodology to her own work. She observed and interviewed potters in the same way as Boas had recommended for basket makers. As a result, Bunzel considered her work to be a vehicle for expressing the ideas of the artists and the subject of her study.

Boas' approach was followed by another of his students, Lila Morris O-Neale (1886-1948). In 1929, O'Neale began her field work with the Yurok and Karok people of the Klamath River of Northern California, canoeing from camp to camp interviewing basket makers (Schevill, 1992: 166-7). Further, O’Neale followed Barrett's methodology of using photographs to elicit details of the construction and design of basketry from the makers (169).

Thus, Bunzel and O'Neale were pioneers in ethnoaesthetic research with respect to aboriginal peoples' material culture (Schevill 1992: 162). Berlo (1992:11) noted that O'Neale also showed great personal interest in her informants and their work. In fact, Margaret Mead (1959: 13) considered Bunzel's The Pueblo Potter: A Study of Creative Imagination in Primitive Art (1929), to be the place where Boas' emerging interest in the individual revealed itself.

It is also important to note the work in eastern Canada of linguist and anthropologist Frank G. Speck (1881-1950), of the New York Museum of the American Indian, Heye Foundation and the University of Pennsylvania. Speck followed a similar methodology in anthropological research similar to that of Bunzel and O'Neale. He 
carried out field work with the southeastern subarctic Algonquin people of Quebec (1915), and with the further eastern Montagnais people (1937). He characterized his approach to research in basketry through interviews with aboriginal people as being more credible than simply working with objects in a comparative analysis (ca.1941, 1937). In his monograph, Montagnais Art in Birch-Bark, a Circumpolar Trait (1937: 45), Speck reconstructed phases of the historical art techniques and decorative concepts of the Montagnais people, noting that research in aboriginal art lacked work in regional comparisons and analysis.

Though there was little research on Northwest Coast basketry through the 1930 and 1940's, research in aboriginal material culture more generally continued. It was encouraged by means of special exhibitions by museums holding collections of aboriginal cultural material. An important early example noted by Rushing (1992: 200) was the Golden Gate International Exposition in San Francisco. The exposition included an Indian arts and crafts exhibit for its opening in 1939. From that time, exhibitions held by museums and art galleries have played an important role in presenting aboriginal material culture to the public. Kew noted (1993-4: 88) that the growing aboriginal material culture collections in museums continued to be "the focus of exhibitions." Subsequently, anthropological research into aboriginal cultures was described through exhibitions that were sponsored primarily by museums and art galleries in both Canada and the United States.

Concurrent with this research, a serious interest in ethnoaesthetics arose among people other than Boas and his students, Berlo noted (1992: 12-3). This was a moment of 
transition to considering aboriginal material culture as art rather than ethnographic objects or curios. Increasing public interest in aboriginal art led to a heightened focus on aboriginal material culture more generally, so that public interest in the history of the material in museums and galleries was also growing. In 1941, Rene d'Harnoncourt of the Museum of Modern Art, New York was instrumental in this change in focus when he prepared an exhibition with Frederick H. Douglas for the American government's Indian Arts and Crafts Board held at the Museum. ${ }^{3}$

At the same time, scholarly research into aboriginal women's work seemed to fall out of favour. Art historian Berlo (1992: 12) stated, "the study of art and individuality fell out of favour in anthropology as attention was turned to other issues," departing from the work of Bunzel and O'Neale.

Catalogues accompanied exhibitions as early as 1869 beginning with the Catalogue of Antiquities and Curiosities Collected in the Territory of Alaska by Edward G. Fast (Anon. 1869). Since then, photographic/essay catalogues often accompanied exhibitions. Another early example was Edgar Hewett's article in Art and Archaeology (1922: 13:10311). In "Native American Artists," he wrote about two young aboriginal painters whose works were concurrently exhibited by the New York Society of Independent Artists (Berlo: 13). In 1931, a catalogue titled "Introduction to American Indian Art" by Sloan and LaFarge accompanied the Exposition of Indian Tribal Arts in New York. (Berlo: 13). Jonaitis (1981:3) traced the shift in focus of anthropology with respect to aboriginal material culture during the 1930 s to the 1980 s. She pointed out $(1981: 27)$ that, by the late 1960 s, seeing aboriginal art as "worthy of esthetic consideration" was an 
accepted point of view. Comparing the interest in Northwest Coast art in the late 1960s with that in the 1970s, Jonaitis noted (1981: 36) that the art was considered "to be of the highest esthetic merit." She also observed (1981: 36), that over the previous fifty years (1920-1970) there were fluctuations in interest in Northwest Coast art that appeared to coincide with events, movements and circumstances in the non-aboriginal society.

In earlier times (ca.1900), when Boas and John Swanton were involved in their ethnographic research on the Haida culture, an increase in popularizing Northwest Coast material culture began. For example, they commissioned work from Haida artist Charles Edenshaw for the American Museum and the Field Museum, Chicago (Jonaitis 28-9, 31).

A shift also occurred throughout this period in the way material culture made by aboriginal people was perceived, classified and written about by anthropologists and/or art historians. Jonaitis observed that since the 1960s, the increase in status of Northwest Coast art was led by aboriginal artists such as Bill Reid (1920-1998) and Robert Davidson who were each deeply involved with their Pacific Northwest Coast cultures.

Bill Holm (1925-), an art teacher in Seattle, Washington, also became interested in Northwest Coast aboriginal art. In collaboration with Bill Reid, Holm wrote Form and Freedom: A Dialogue of Northwest Coast Indians (ca.1975). Jonaitis noted (1992: 28) that it was "a much-needed aesthetic evaluation" of specific Northwest Coast art objects. She credited (28) Holm's work in identifying Northwest Coast artists as individuals that placed them in the category of "fine artist."

Noting that aboriginal basketry and its makers did not receive the same attention and appreciation as carved aboriginal art did, Berlo and Phillips (1998: 32) pointed out 
that distinctions were made between works of art produced by men with those made by women in most indigenous societies. In this regard, it can be noted that attention to Northwest Coast aboriginal people's art has for the most part focused on items traditionally made by men. Aboriginal women's work such as basketry was not seen important enough to revitalize or to research. Traditionally, the production of basketry has been undervalued because it has been the work of aboriginal women. Turner (1996: 1-4) stated,

"[basketry] reflects a complex system of knowledge incorporating not only the techniques of the art, but the ecological and cultural aspects of harvesting and processing the materials. The importance of women's roles as contributors in the aboriginal traditional economic system has been unrecognized."

To further illustrate this point, Turner noted that in past archaeological findings of tools, almost exclusively only implements within the domain of men's hunting and fishing tools were identified. Tools utilized in basketry, such as awls, knives, bark peelers, and root scrapers have been recognized only recently in contemporary archaeological research (1966: 4). Moreover, in later years, subsequent scholarly work in basketry began to change public perception.

Boas's approach to research in basketry had developed gradually and been recorded in Primitive Art (1927). He (18) noted in the context of the California aboriginal basketry that basket making was an occupation of women while the work of aboriginal men was insignificant. On the other hand, in a reference to household goods and implements made of wood by the aboriginal people from Puget Sound northward, Boas noted that basketry played a "relatively unimportant part" of artistic expression, while 
production of art by men in any other material than wood was "weak." Thus, in Boas' view, (1955: 18) Northwest Coast men were the creative artists while the women lacked "inventiveness and artistic sense." Berlo and Phillips (1998: 33) attributed a male bias through "value judgements based on a Eurocentric, patriarchal approach" of postEuropean observers writing on aboriginal art. This may explain why interviews with northern British Columbia aboriginal women artists were not seen as being important to anthropologists, ethnographers and others.

The exhibition catalogue, Topographies: Recent Aspects of B.C. Art, Doreen Jensen, Monika Ken Gagnon and Grant Arnold (1996), written in conjunction with the 1996 exhibition at the Vancouver Art Gallery, demonstrated contemporary approaches to aboriginal art including basketry. It is an example of a reflexive approach to collaboration between aboriginal artists and curators in the context of museum exhibitions. In the catalogue, Jensen's essay Isabel Rorick: Basket Maker Artist Speaks (1996: 91-122) traced historical trends in how British Columbia's aboriginal people's art had been perceived and reflected in exhibitions at the Vancouver Art Gallery. As did Berlo and Phillips' gender analysis, Jensen (114) stated that since 'basketry is traditionally women's work," even though basketry was highly regarded by all aboriginal people, "its practitioners have not been accorded the same status as male artists." For example, Rorick's great-grandmother, Isabella Edenshaw, rarely received recognition for her basketry, though her husband Charles Edenshaw, who painted the hats that Isabella wove, was an acclaimed artist. 
Exhibitions of aboriginal art continue to travel today, reflecting it's popularity and wide appreciation of aboriginal people's art. Along with changes in the status of women, these trends have shifted the way aboriginal material culture including that produced by aboriginal women has been perceived, described and written about.

Berlo's anthology, The Early Years of Native American Art History (1992), incorporated an analysis of the evolution of aboriginal people's art history. In "The Artist Himself": The Salish Basketry Monograph and the Beginnings of a Boasian Paradigm, (134-161), Ira Jacknis revisited Haerberlin's and Teit's work, considering the impact that their research had on subsequent researchers. Schevill traced (162-190) O'Neale's methodology in Lila Morris O'Neale: Ethnoaesthetics and the Yurok-Karok Basket Weavers of Northwestern California reiterating that the main objective of research in basketry is to learn the aboriginal peoples point of view.

Other writers have approached basketry from the paradigm of technical stylistic analysis. These have included Sue Devine, "Spruce Root Hats of the Tlingit, Haida and Tsimshian" in American Indian Basketry (1982 (1, 4): 20-5), and "Kwakiutl Spruce Root Hats," (1981 (1, 4): 24-7). Andrea Laforet, a specialist in the study of Northwest Coast woven basketry has written several analytical papers such as: "Tsimshian Basketry" in The Tsimshian: Images of the Past: Views for the Present (1984: 215-180); "Regional and Personal Style in Northwest Coast Basketry" in the context of woven spruce hats in The Art of Native American Basketry (1990: 281-298); Hats of the Northern Northwest Coast presented at the Ninth Annual Conference of the Canadian Ethnology Service (1982). 
For this study the data on birch bark basketry are limited because of anthropological practices at the time of collection. Conversations with the basket makers or collectors and similar contextual information were generally not recorded. Indeed, in my review of the published literature of history and culture of the Wet'suwet'en Carrier people, only one passing reference to the basketry work of women could be found (Cassidy 1987: 17). Another was found in the unpublished documentation of the material culture that ethnographer C. Marius Barbeau collected. However, like most of the other collectors of the birch bark basketry considered here, he failed to elicit the salient features and details of most baskets that he collected. Therefore, in my research, I have attempted to compensate for the lack of ethnographic information by turning to the traditional knowledge of a few remaining elderly basket makers and using other indirect sources. Specifically, I obtained personal data through several interviews with the contemporary basket makers as well as from vital statistics records and photographs, wherever possible. These assembled data have enabled a narrative to be told through both the basketry and the surviving basket makers in Chapter Five.

Through time, changing perspectives in anthropology have led to different approaches in the study of aboriginal material culture as discussed above. Some of these various methods are utilized in this thesis and are discussed in Chapter Four.

Furthermore, Aldona Jonaitis (1992:22) stated that, today, analysis and interpretation of aboriginal art (basketry in this case) should include and reflect the identity of the narrator. Thus, the analysis reflects my point of view coming to the collections from outside, looking at baskets as objects, but with a critical attraction to, and a bias 
toward, thinking about their form and decoration as a factor in my perception of the subarctic basketry in the collection.

In the next Chapter, the transitions experienced by subarctic aboriginal basket makers in each region, from pre-European to post-European times, are considered in their geographic and sociohistorical contexts. 


\section{Chapter Three}

\section{TRANSITIONS FOR SUBARCTIC ABORIGINAL BASKET MAKERS}

This Chapter is divided into two major sections following an overview of the historic events that impacted subarctic aboriginal basket makers. The first section considers the traditions and experiences of the Carrier basket makers. The second section considers those of the Algonquin/Montagnais basket makers. Although less is known about the latter, their experiences are included as a counterpoint to those of the Carrier women. In the respective sections, aspects of the geography, ethnography and history of each subarctic region that have affected basket makers roles' and production are discussed. These include issues such as the impacts of trade, economic dependencies, access to traditional lands and resources, social relationships, and a gendered division of labour through these times. The relationships of these factors to the distinctive forms of birch bark basketry are noted. Some of the information in these sections is based on early ethnographic records of the Carrier and Algonquin/Montagnais people. ${ }^{4}$

\section{Overview of Historic Events}

The subarctic region of Canada consists largely of the heavily forested Boreal ecological zone that is home to the Montagnais, Algonquin and Carrier people, described by June Helm and Eleanor Burke Leacock (1971: 343-6) in The Hunting Tribes of Subarctic Canada (see Map 1). Stretching across 2,500 miles of northern Canada, the subarctic region extends from the eastern Atlantic Ocean and Labrador peninsula to the 
southern shores of Hudson's Bay in Eastern Canada. It continues to the MacKenzie River lowlands, then across the northwestern interior of British Columbia and north to the Arctic Circle. In this land of lakes, streams, muskeg, mountains and plateaus, the winters are severe and long, while the summers are mild. In pre-European times, subarctic aboriginal people subsisted by living on the land. They moved to their fishing sites in the summer or to their hunting camps in the winter. They knew the land intimately as they moved with the seasons to support themselves using traditional knowledge passed down by their ancestors.

With the advent of European settlement in North America, beginning in Atlantic Canada between 1500 and 1534 (Ray 1996: 38), the traditional way of life for Canadian aboriginal people was impacted in several ways by European culture.

By the 1850 s, European settlers began to arrive in what is now Western Canada. The Hudson's Bay Company (hereafter the HBC) gained a monopoly on the fur trade beginning in the mid-seventeenth century in most of Canada including Algonquin/ Montagnais territory, and in Carrier territory early in the nineteenth century. The impact experienced by northwestern and other aboriginal people throughout Canada was that of domination by a new economy (Ray, 160), causing disruption of their ways of life. The people of the land were forced to adapt to new means of supporting themselves in the changing society. Both women and men now worked in the fur trapping trade, commercial fishing, the canning industry as well as, the forest industry. They supplemented a seasonal family income with other jobs such as local guides, interpreters 
and freight packers, construction of highways and railways near their communities, and traveling as members of construction crews that moved from site to site.

At the same time, aboriginal women supplemented their family income in the production of material culture such as basketry. These means became increasingly necessary as their traditional way of life diminished within the new Euro-Canadian culture and economy. Thus, the impact of European settlement on the traditional pursuit of basketry was, on one hand, to decrease the reliance on it as a traditional article of commerce and domestic use, and on the other hand to support continuation of the art as an item for sale to collectors and travelers.

\section{PART I: Western Subarctic CARRIER PEOPle}

\section{Pre-European Times: -}

\section{SEASONAL ROUNDS}

The Carrier peoples traditional movement across the land followed a process known as 'seasonal rounds' that took advantage of the seasonal availability of food sources at various locations. In their seasonal rounds, the Wet'suwet'en Carrier people relocated from their winter hunting camps to summer fishing sites on nearby rivers for the annual harvest of salmon during the spawning runs (Cassidy 1987: 17). For example, they established a large summer camp in 1872 with twenty longhouses on a ledge above the Canyon at Hagwilget to serve as a base for this seasonal fishery.

According to Cassidy (1987: 8), in pre-European times the northern Wet'suwet'en Carrier, Gitksan and Sekani people all lived in a village known as Diztlegh, or Mosquito 
Flats. It was located on the Bulkley River near the present day town of Hazelton (see Map 3). In the late nineteenth-century, some of these aboriginal people expanded their northeastern territory, while some Carrier people moved into Sekani hunting territory (Tobey 1981: 413; Jenness 1934: 241). The Sekani people subsequently went north, while other Carrier people went to Babine Lake and further east. And, the Gitksan people moved westward to present day Gitanmaax, a mile from Hazelton (Cassidy, 1987: 9) (see Map 3).

Until the nineteenth-century, the southern boundary of the Carrier region extended from the HBC's Fort Alexandria in the east (see Map 2), westward to a point midway between Ulkatcho and Anahim Lake. More recently, the southern boundary was near the settler town of Quesnel, while the northern boundary was near the settler town of Hazelton. Aboriginal neighbours from the south to the west included the Secwepemc (Shuswap) people, the Naka'pamux (Thompson) people, the Tsilhqot'in (Chilcotin) people, while the Nuxalk (Bella Coola) people were to the west (Duff 1951:165). Neighbours of the Carrier people to the northwest included the Haisla, Interior Tsimshian, Gitksan and Nisga'a people. To the north and east were the Sekani, Beaver Cree, and Babine people (see Map 4).

\section{POPULATION}

Early population estimates varied greatly for the Carrier people partly due to the fact the Canadian Government 1880-81 Census (Vol. 2-3) omitted the aboriginal population north of Quesnel. However, Cole Harris with Robert Galois (1997: 138, 146- 
7) in A Population Geography of British Columbia in 1881 cross-checked other census records and sources with the 1881 Census. However, as the northern interior was sparsely populated, it was estimated to have less than one person for every 150 square kilometers. Tobey (1981: 426) reported that there were seventeen Carrier bands living in more than two hundred separate reserves located mainly along the river systems in the northern interior. Elizabeth Furniss (1993: 1) noted that, according to the Department of Indian and Northern Affairs (Prince George Office) records in 1992, there were eighteen Carrier bands registered.

In an accounting of the Carrier population in 1964, Wilson Duff (1992 [1997]) noted that for the twenty Indian Agencies of the Department of Indian Affairs in British Columbia, the reported total population had rebounded to 40,800 . He further provided population figures for the Carrier Agencies of interest here: 2,601 for the Babine Agency at Hazelton; 995 for the Burns Lake Agency at Burns Lake (mostly Babines); and 2,187 for the Stuart Lake Agency at Vanderhoof (Duff 1997: 90). Thus, there were 5,783 Carrier people who represented fourteen per cent of the total aboriginal population of 40,800 for British Columbia and the B.C. Region of the Yukon (Whitehorse office).

\section{GEOGRAPHY, ENVIRONMENT, AND SUBSISTENCE}

The flat and wide landscape of British Columbia's northern interior, known as the Cordilleran plateau, has been the home of the Carrier people. The Cordillera runs almost directly north-south down the Pacific coastal mountain ranges. South of the Cordillera 
Plateau is a combination of desert-like and forested mountains in the southern central interior and Okanagan regions of British Columbia (McClellan and Denniston 1981: 372).

The unique environment of the Cordillera is the result of the influence of the coastal mountain range that modifies the flow of air from the warm and moist Pacific coast environment. The mountainous environment that overall surrounds the Cordillera helps to create the cold and dry interior climate (Barman 1966: 9-10).

McClellan and Denniston (1981: 374) noted another important feature of the Cordillera: the four major river systems. They provided the main sources of food for the Carrier people, and also the main transportation routes. The Skeena River (see Map 2) is at the northern perimeter of the Cordillera, draining westward into the Pacific Ocean. The Bulkley River that meets the Skeena has a primarily north and south orientation, extending southward through the Skeena, Bulkley and Kispiox Valleys. At the southwestern boundary of the Cordillera, the Bella Coola River drains westward into the Pacific Ocean (see Map 2). Finally, the Nechako and Fraser Rivers at the southern boundary of the region drain in a southerly and eventually westerly direction to the Pacific Ocean. The geographic areas at the connecting points of these rivers were important areas of habitation and trading for the Carrier people.

\section{FOOD AND ECONOMY}

The southern and central Carrier and the northern Wet'suwet'en Carrier people lived a seasonally mobile life. Their mobility was necessary for harvesting their various sources of food. Steward (1960: 733) noted in Carrier Acculturation: The Direct 
Historical Approach, that in the traditional Carrier economy, fifty per cent of the subsistence diet was derived from several species of salmon (Salmonidae), supplemented by moose (Alces alces) and white-tailed deer (Odocoileus hemionus columbianus). Fresh water fish was also a seasonal food source, especially when the salmon runs occasionally failed (Tobey 1981: 417; 15-17). McClellan and Denniston (1981: 374-5) noted that fresh water fish was a trade item for the southern Carrier people while Beryl Gillespie (1981:16) stated that minor food sources included migratory water fowl such as swan, geese and ducks that passed through the subarctic region in the spring and fall months. Early Carrier basket makers often used quills from these fowl to decorate the rims of their birch bark basketry.

Across the subarctic, the primary tree species within the boreal forest are paper birch (Betula papyrifera), black spruce (Picea mariana), and white spruce (Picea sitchensis) (Helm and Leacock 1971: 343-6). Minor tree species such as pin cherry (Prunus pensylvanica) are also found in the region.

The particular ecology of the western Cordillera and other regions determined the availability and type of natural resources used in the material culture of the aboriginal people (Helm and Leacock, 1971: 346). However, all subarctic aboriginal groups adopted similar methods and equipment in food gathering, preparation, preservation, and consumption.

Among the obvious common practices was the use of the various sizes in the subarctic birch bark baskets. Small baskets were used in berry-picking (see Plate 1) and as drinking cups or eating dishes. The medium size or larger baskets held berries, water, 
items for storage, or were used in preparation for and in cooking (see Plate 2). In cooking, hot stones were dropped into the contents of the basket, generally water with meat in it or water to be boiled to make tea (Helm and Leacock, 346).

In his field work, Harlan Smith noted that the birch bark baskets were made into three types, "dishes - pails, large trays, and boxes." Birch bark was also used "to make spoons or as handles for stone adzes." Large and small pails or baskets were sewn with spruce roots, he noted, and some pails were used for boiling food over fires. Large trays measuring approximately four inches deep were used for gathering soapolallie (Shepherdia canadensis $)^{6}$ berries, or for holding meat that was eaten from the tray. Smith found that Carrier 'birch bark boxes' [sic] were generally about twelve inches square. ${ }^{7}$

Tipis covered with birch bark were used for shelter throughout the subarctic region. The Carrier people made double brush-covered birch bark lean-tos on occasion. Tobey (390) noted that the Carrier people also used birchbark at their summer fish camps for both shelter and fish drying purposes. Moreover a number of subsistence tools such as birch bark basketry, were critical to survival in a formidable seasonally mobile way of life that allowed few luxuries (Helm and Leacock 1971: 234).

\section{Transition of Western Subarctic Carrier People}

Tobey stated (1981: 413) that she was able to identify fourteen Carrier groups with a distinct language that is an important component of identity. Morice (1892: 109) recorded more than twenty Carrier villages by name and location in his work Are the Carrier Sociology and Mythology Indigenous or Exotic? (1892). Detailed classifications 
and definitions of the Carrier groups and communities were provided by Morice (1895: 24-30). Together with Wilson Duff's (1951) component groups/subtribes, and W.F. Tolmie's (see Plate 8) and G.M. Dawson's (1884) data, Tobey (1981: 413-5) was able to distinguish Carrier groups linguistically.

In the end, however, Tobey (1981:415) preferred to use the sociopolitical and geographic designation of the Carrier people that is followed here. The southern Carrier people lived primarily in the Fraser Lake and Anahim Lake communities. The central Carrier people are from the Sai'kuz (Stony Creek) (see Plate 3) and Natliwoten (Nautley) communities in the vicinity of Vanderhoof (see Map 4). The northern Wet'suwet'en Carrier people lived in the area between Moricetown and Hagwilget Canyon community near Hazelton.

Maureen Cassidy and Frank Cassidy in their joint monograph, Proud Past: A History of the Wet'suwet'en of Moricetown, B.C. (1980:6) observed that the northern Carrier people lived in the Bulkley River basin and called themselves the Wet'suwet'en people from early times. Cassidy (1987) noted that they were known locally as the Bulkley River Carriers. Their community was located near their original boundary with the Gitksan people in an area known as Mission Flats. However, they eventually settled at Moricetown, beside the Moricetown Canyon.

In 1920, this part of the Bulkley River was impacted by the collapse of the river canyon wall to the north, near where the Bulkley and Skeena Rivers meet. The collapse blocked the river and the salmon run. This disrupted the Moricetown Canyon traditional salmon fishery. Subsequently, in exchange for permission to fish on each other's side of 
Chapter Three / 23

the upper canyon, the Gitksan Chief of the Gitanmaax reserve gave the Hagwilget reserve to the Wet'suwet'en Carrier people, and hence access to fishery below the blockage. In 1820, the Carrier people relocated from Moricetown to Hagwilget (Cassidy 1987: 8-9). The Hagwilget Reserve is three miles from the settler town of Hazelton, high up on the south side of the canyon (see Map 3).

\section{ABORIGINAL TRADING NETWORKS}

The Carrier people's subsistence seasonal rounds were supplemented by trading of various commodities with the neighbouring aboriginal groups through their ancestral trade networks (McClellan and Denniston, 1981: 373). They traded raw resources such as fur, salmon, and fresh water fish with their coastal neighbours and others along the network. This led to an important, complex aboriginal trading system controlled through a limited number of access points. The primary traditional gathering points were near Hazelton on the Skeena River, at the Bella Coola inlet and, to a lesser extent, on the Fraser River. The trading networks contributed to inter-aboriginal relationships and eventually led to first contact with the European explorers and traders.

The Wet'suwet'en Carrier people were key players in the extensive trading network. Their southern trading partners were the Ulkatcho Carrier people, the coastal partners were the Bella Coola people, and the central partners were the Carrier people. The southern route followed an overland/Riverine trail from the Bella Coola River, north to the Dean (formerly Salmon) River (see Map 2), the Blackwater River and the Upper Fraser River. Supporting archaeological evidence for the trading trails was found at 
Chinlac (Tobey, 1981: 416). Margaret Whitehead (1981: 27) noted that the neighbouring Tsilhqot'in people were also trading allies on the southern route.

Cassidy (1987: 6) explained that, along the northern trading routes, the Wet'suwet'en Carrier people were pivotal trading partners between the Babine people, the Gitksan, the Tsimshian, the Nisga'a people, and the southern and central Carrier people, who in turn traded with their neighbouring northwest coast trading partners (Cassidy 1987: 19). Other indirect trading partners on the route were the Haisla, Tlingit, Tsetsaut, and Kitamaat people. The Gitksan people tended to be the middlemen between the Tsimshian and Nisga'a people although historically the Tsimshian coastal people came to the Hazelton area to trade.

Barman (1966: 15) noted that by ca.1750, there were more than fifty types of goods that were brought together from trade along twenty separate aboriginal trading routes. She estimated that approximately ten thousand people from different aboriginal groups gathered to trade at Port Simpson in the estuary of the Skeena River which became the principal inland route for the northern trading network (Tobey, 1981: 375). At the upper end, near Hazelton, trading was centralized at Mission Flats, or "Mosquito Flats" (Jenness: 1924-5:21, 1925; Cassidy, 1987: 19). The Flats were close to both the Wet'suwet'en Carrier Hagwilget reserve and the Gitksan Gitaanmax reserve.

McClelland and Denniston (1981: 375) observed that the central Carrier people, some of whom lived on Stuart Lake, could not rely on the salmon runs for sustenance. When possible, they traded locally harvested fresh water fish for salmon and other goods that possibly were transported in their basketry with the Ulkatcho Carrier and/or the 
Secwepemc people (see Map 5-6). Along the network, there were two main trading routes known as Grease Trails. The name for the trails came from another regularly traded commodity, eulachon oil. In the film Grease, Al Elsey (1964) documented the Nuxalk people harvesting a year's supply of eulachon for their own use, as well as enough to trade with the people of the interior of the continent. He noted that grease trails were travelled by hundreds of people for trading purposes. They packed the Eulachon and/or its oil on their backs. The fish and its oil were a main food source, with most of the total fat intake coming from the oil. ${ }^{8}$

The Wet'suwet'en Carrier traders obtained furs from their eastern Athapaskan neighbours in exchange for Northwest Coast goods including copper, eulachon oil, and dentalia shells that constituted a form of money (Cassidy and Cassidy, 1980: 16). Tobey (1981: 375$)$ and Cassidy (1987: 19) both noted that at the Flats annual trade fair, coastal trade commodities included dried salmon, fresh water fish, berries, sealskins, kelp and other dried seaweed, herring eggs, among other maritime products. They were exchanged for eastern and northern inland tanned moose and caribou hides, hooves, sinew and smaller animal skins such as marten.

The Wet'suwet'en Carrier people initially acquired European trade goods through trade with their coastal neighbours, who in turn traded with traders from European ships. Basketry may have contained some of these goods or be actual trade items. The coastal Tsimshian, who were mountain as well as sea dwellers (Garfield n.d.:5), had a regular trading route to Bulkley Canyon, and a trade monopoly with the Babine [Carrier] people. They bartered trade goods and preserved sea foods with the Babine traders in exchange 
for furs (Garfield n.d.: 7). Morice recorded (1978: 209) that in 1850, as European trade goods were entering the northern interior, the Tsimshian tried to eliminate the Gitksan middlemen who traveled downstream on the Skeena River to trade as well as to control the rich salmon runs at Babine Lake.

This coastal European trade began in the late 1700s with Russian, Danish, British, and Spanish traders, Gibson noted (1992: 260-1) in his historical work, Otter, Skins, Boston Ships, and China Goods: The Maritime Fur Trade of the Northwest Coast, 17851841. Barman (1966: 28) pointed out that the volume of goods increased due to trade from the maritime otter fur trading ships with coastal and interior trading posts. By 1799 , Russian entrepreneurs had established ten settlements in Alaska. The interior aboriginal trading network ultimately linked with these sites through trade for goods that could have provided artistic ideas and uses in the manufacture of basketry.

\section{Post-European Influences}

Historian Olive Patricia Dickason traced the beginning of the European fur trade on the Northwest Coast of British Columbia in (2002), Canada's First Nations: A History of Founding Peoples from Earliest Times, from the sea otter fur trade on the coast between British, American and Russian traders, and China that initiated the European fur trade in western Canada. By 1825 , the otter trade was over and Northwest Coast traders were looking for other resources. This late contact with European people allowed the western aboriginal people to practice their cultural traditions longer than those in the east. 


\section{Fur TRADE ESTABLISHED}

In this same period, beginning ca. 1828 the Carrier people began to lose their land and resources to European settlers (Harris 1997: 31-4) in the overland fur trade. In that year, the HBC Governor, George Simpson, arrived at the Stuart Lake Fort. With trader James Douglas ${ }^{9}$ in charge, the dispossession of the aboriginal people began. Under Douglas' jurisdiction, the HBC created a "proto-colonial presence" in the Cordillera. The officers organized the Carrier people and disciplined them into establishing a profitable trade business in the region (Harris 1997: 31-34). Fiske and Patrick (2000:146) noted in Cis dideen kat $=$ When the Plumes Rise: The Way of the Lake Babine Nation how European presence was imposed on the Carrier people through the power of the HBC's sweeping edicts.

A competitor, the Northwest Fur Company, established its first western post at Fort McLeod in 1805. It later became an HBC post (see Map 2). Its purpose was to offset the aboriginal trading network at Mosquito Flats. In 1806, the Fort Fraser trading post was established at Fraser Lake (McClellan 1981: 389; Tobey 1981: 417-8). Morice (1978: 67) stated that the Fort was established to extend food supplies due to a scarcity of food in the region. It was closed in 1818 , but was re-opened by the HBC in 1821 . Fort Babine (Kilmaur at the time) was established at the north end of Babine Lake by the HBC ca. 1822-36 (McClellan 1981: 389; Tobey 1981: 417-8; Garfield n.d: 7).

Thirty years later (in 1866) the HBC established a post at Hazelton. The following year, Simon Fraser established the HBC post at Fort St. James overlooking Stuart Lake (see Plate 4). It subsequently became the headquarters of the fur trading district of New 
Caledonia, the provincial designation for the Cordillera region, according to Tobey (1981: 418).

Morice reported that trading began at Fort St. James when it was completed, and eventually became the center of the northern fur trade (Whitehead 1981:38). The fur trade eventually declined in the western subarctic due to over-hunting and new government administrative policies and programs (Barman 1966: 165). However, the policies had created an economic dependency for the aboriginal people. ${ }^{10}$

After 1918, Fort St. James ${ }^{11}$ became engaged more in retail sales than fur trade (Tobey 1981: 418). By 1900, the increase in post-European commercial trade on the Skeena River from the coast spread to the territory of the Wet'suwet'en Carrier people. As part of the increase in trade, the settler society developed an interest in the art of the aboriginal people both in the well known Northwest Coast carved art and in other British Columbia decorated utilitarian art including birch bark basketry. At the same time, commercial trade from eastern Canada was beginning to reach the British Columbia interior.

Tobey (1981: 387-8) noted that access to the rich coastal material culture of their neighbours helped buffer the Carrier people from the assimilation practices of the new government for a while. The HBC favoured patrilineal powers over the Carrier's traditional matrilineal rights. The result was conflict with local groups. The HBC also supported missionaries who acted as or appealed to magistrates under a regime of colonial law and order. Fiske (1996: 149) stated that their objective was to disempower Carrier society in competition for the lands and natural resources. As settlements developed 
around the trading posts, the Carrier land was taken over by the settlers who were developing farms. McClellan (1981: 389) noted that the loss of land further increased the Carriers' dependency on the new economy. Similarly, the introduction of a wage economy in forestry related industries and fish canneries in the mid-1800s created an economic dependency on non-traditional employment (McClellan 1981: 400). At the same time, aboriginal women increased their production of basketry for sale to settlers and travellers, McClellan noted (1981: 397). Also, the trading company introduced a credit system whereby food and goods were advanced against a season's trapping (393-4). This further created an economic dependency for the Carrier people on the trading company.

The increased reliance of aboriginal people on trade goods was not the only impact of the trading company posts. The fur trade was a violent experience for aboriginal people because they were under threat of physical means to subjugate them into cooperating with the traders (Harris, 1997: 63-4). Power was maintained through control of the distribution of European goods, including alcohol and firearms. Non-violent strategies included marriage with aboriginal women in the "politics of divide and rule," although this may not have been a policy of the Governor himself.

An account of activities in Hazelton, located at the terminus of river boat traffic on the Skeena River 200 miles inland from the coast, was recorded by Father Nicholas Coccola and published by Margaret Whitehead (1988: 142-3) in They Call Me Father: Memoirs of Father Nicholas Coccola. From Hazelton, packers or pack horses then delivered the supplies to their destinations throughout the Cordillera on roads originating from the traditional trade networks. 


\section{GOVERNMENTAL REGULATIONS}

An influence that drastically affected the ability to pursue traditional subsistence and social practices was the government structure and regulations that were imposed on the Carrier people. Under the 1867 British North American Act, the federal government became responsible for aboriginal people. In 1880, the Department of Indian Affairs was established four years after the first Indian Act was proclaimed (Dickason 2002: 263; 1992: 275). For the first time, in 1879 , British Columbia surveyors were instructed to record all Indian cabins, fields and villages on their plans, according to provincial surveyor Frank C. Swannell (see Plates 5 and 6).

Following a long series of attempts by the federal government to create a structure for organizing aboriginal affairs in British Columbia, the Department of Indian Affairs established its presence in British Columbia in 1874 with the office of the Minister of the Interior under the authority of the Superintendent General. From 1881, the federal government began to create more Indian agencies in British Columbia (see Duff: 1997 : 90). Duff recorded that the Indian Reserve Commission named the Hagwilget reserve for the Wet'suwet'en Carrier people, consisting of the Fort Babine Band, the Old Fort Babine Band, and the Moricetown Band (Duff 1997: 49) (see Duff 1997: 27-52 for a complete list).

The Department of Indian Affairs, Babine Agency was created in 1889 and located at Hazelton. The reserves within the Babine Agency's mandate as administrator of Indian Bands were under the supervision of Indian Agent, Richard E. Loring. Further, Knight 
(1996: 114) noted that in British Columbia, reserves were smaller, more scattered and more numerous than in other parts of Canada.

In 1896 , Loring wrote from Hazelton that the majority of the aboriginal population (excluding the aged) continued to leave for their summer fishing camps and to return to trade. He wrote, "the Heuguel-gets are very slowly in coming this season, to do their trading." ${ }^{2}$ Loring's note reflected the attempts of the Wet'suwet'en Carrier people to continue their seasonal rounds and their trading practices. It confirmed that the Wet'suwet'en Carrier people came to the Hazelton area to trade, and were collectively referred to (along with the Kispiox or Kisegas people) as being from Hagwilget. Moreover, his note acknowledged the inter-cultural trading relationship of the Carrier, Gitksan and Babine people who lived in the vicinity of Moqusito Flats (see Map 3, 5).

The relatively late establishment of the Babine Agency (Babine and Upper Skeena) $)^{13}$ in 1889 reflected the fact that the Hagwilget community faced the arrival of settlers and developers later than other areas. It was almost forty years earlier that the southern aboriginal people had a similar experience (Laforet and York, 1998). The year 1910 saw the end of the Indian Superintendent's position, the end of the Indian Reserve Commission, and the division of British Columbia into three Inspectorates - Northern, Southwestern and Southeastern.

In 1904, Loring divided the reserve land into lots and assigned specific ones to various Wet'suwet'en Carrier families. However, this occurred while the families were scattered throughout the Bulkley and Kispiox Valleys at their hunting and/or fishing sites. 
Loring's allocation thus misconstrued demographics and ignored the Carrier family structure (Cassidy and Cassidy 1980: 27-8).

Whitehead (1988:163) noted that in 1910, Father Coccola had recommended to the federal government that the Babine Agency be divided into two Agencies, with one Agent at Stuart Lake and the current one remaining in Hazelton. Subsequently, he found an Agent for the new Stuart Lake Agency who was accompanying surveyors embarking on plans to locate a reserve for the Stuart Lake Carrier people. Loring (1911: 192) in his 1911 annual report wrote,

"This agency is of all in British Columbia the most northerly situated, and is bounded towards the north and west by the former Northwest Coast agency, now divided into several, towards the south by the Williams Lake agency, and on the east by the lately established Stuart Lake agency, previously forming a part of this."

\section{RELIGIOUS INSTITUTIONS AND PRACTICES}

The federal government's decision that aboriginal children were to attend residential schools contributed to the assimilation of aboriginal people into European society. These schools were operated by missionary Orders of the Roman Catholic, Methodist, Presbyterian, and Anglican Churches that were centrally involved in imposing European values on the Carrier people.

According to Lemert (1954: 23-7), one technique used by the Oblates of Mary Immaculate (OMI) in British Columbia was known as the Durieu System, whereby the missionaries imposed stringent punitive measures on aboriginal people. The Durieu System was a model of an autocratic moral and economic order that arguably caused maltreatment of the aboriginal people of British Columbia although it became the model 
for Roman Catholic missions throughout Canada. ${ }^{14}$ Fiske (1996: 169-70) stated that the goal of the Church was to enforce its teachings on the community as a whole through the residential schools. However, Smith (2001) pointed out in his paper on the postConfederation residential school system that the schools were a federal government project for the 'civilizing' of aboriginal people, and were staffed by missionaries, who were government appointees.

The experience of the Carrier children was centered at two residential schools in the region. They were the Lejac School on Fraser Lake that was in operation from 1910$1976^{15}$ (Fiske 1996: 167-82) and St. Joseph's School in the southern region (Whitehead 1988: 27). The Lejac school was named after the priest-in-charge, Father Lejac, (Mulhall 1986: 74-5).

The federal government, through the Indian Agent and the priests, removed many Carrier children from their homes to spend extended periods of time, often years, in the schools. The parents were encouraged to send their children to the schools on the basis that they were "designed to support and augment economic and social transformation" in the new economy, according to Fiske (1996: 175). In her view, parents were led to believe that they were preparing their children for a future in the new economy.

The full impact of the schools was felt when the parents realized they were losing productive labour at home and cultural knowledge for future generations. Traditions such as clan-based exchanges and trade in basketry and other domestic products that provided independence to Carrier women were lost to their children (Fiske 1996: 179). An example was the life-learned knowledge in fishing and trapping techniques. This would also have 
been the case for the loss of potential Carrier basket makers. While still free to make baskets to supplement their family income when their children were in the Residential Schools, Carrier women were not able to pass these traditional teachings down to their children. Instead, the children were learning Euro-Canadian domestic methods suitable for use as future farm wives, Fiske (1996: 172) noted.

On the other hand, for the immediate times, women whose children were placed in residential schools were able to spend more time on their own trapping and fishing (Fiske 1996: 175). They were able to seek more opportunities to earn money in the work force alongside their male counterparts. This was both a cause and result of the gradual loss of the traditional aboriginal economy and way of life. Paradoxically, as Fiske (1996: 181) noted, the experience in the Lejac Residential School also empowered the Carrier women to become respected leaders in their communities. In the end, Fiske found that, with some Carrier former students of Lejac school at least, the Church and government did not entirely succeed in their program of social change.

\section{ECONOMIC CHANGE}

The assimilation of aboriginal people into the burgeoning European economy drew them farther away from traditional pursuits and into relations of employment and survival. One point of view on economic change suggests that the aboriginal people were assimilated into a dependency relationship to the burgeoning economy which drew them away from trade relations. McDonald (1984: 40) disagreed, stating that the Tsimshian aboriginal commercial fishers and cannery workers were critical to the success of the 
fishing industry throughout coastal British Columbia and were not solely or simply dependent upon the canneries for their economic life. Knight stated (1996: 179) that the central and northern canneries continued to need aboriginal people, including the Carrier people for many years.

Aboriginal women worked in the canneries packing salmon into cans. They were crucial to the industry well into the 1900 's. Knight $(1996: 194)$ noted that the women repaired nets for the canneries before and after the fishing season. Industry control dominated the fishery until the early 1920 s, creating a seasonal dependence on cannery boats, nets and supplies to meet its needs from April to June (Knight, 1996: 109-113).

Furniss (1993: 49) noted that the logging industry also affected the Carrier territories. Alienation of the most accessible Crown timber land by lumber companies and speculators occurred between 1900 and 1910. By 1910-1911, aboriginal men were encouraged by Department of Indian Affairs policies to work in every capacity in the logging and sawmill industry, including on reserve tracts. Many had been working in this seasonal occupation for a generation along the Skeena River, as well as in other areas in B.C., according to Knight (1996: 237-8). Male and female Carrier workers traveled to and between fishing and canneries, lumber and sawmills, packing, freighting and sternwheelers, and, railways and telegraph and other jobs. The need to earn money to meet family and community responsibilities and obligations in the new culture meant that they had to continue to be in the work force. 


\section{ABORIGINAL ENTERPRISES AND GOVERNMENT RAILWAYS}

Carrier people were also independent entrepreneurs in the northern economy. Despite conventional belief, there were a number of Gitksan and/or Carrier owned/operated mercantile businesses in Hazelton around 1900 according to Knight (1996: 163). There was a Gitksan and/or Carrier owned sawmill at Kispiox. Organized as a Band venture in 1898 , it grew into a commercial business selling lumber in the Hazelton area to Gitksan and Carrier people, and European settlers. By 1909, the mill was operating on a two-shift basis, providing employment for local Carrier sawmill workers and logging crews. The sawmill also provided material for the construction of homes at Kispiox (Knight 1996: 318).

Changes were also occurring in the trapping industry. By the end of the 1880 s, Carrier men and sometimes women who had been trappers were equipped with European material culture including clothing. Mulhall (1986: 100-1) noted that their traditional communities were abandoned as they built timbered homes near the trading posts. They also established agricultural practices, and were hired by the HBC as fur packers, farm labourers, carpenters and deckhands on the lake boats.

\section{EVOLVING ROLE IN TRANSPORTATION}

Trail-packing was historically another occupation for the Carrier people on trails that ran from the southwestern Cordillera through to Hazelton. The Carrier also acted as guides for provincial surveyors such as Provincial Surveyor Lieutenant Frank Cyril Swannell. ${ }^{16}$ Packing was essential to the early European development in the Cordillera. 
For example, the Carrier workers at Fraser Lake were important subcontractors engaged in horse packing transport chains passing through the region, and human back-packing from the late 1860s to World War I (Knight 1996: 260-1). They also worked as wranglers, and established their own horse-packing outfits.

Supplies were shipped upriver on the Skeena River to Hazelton in dugout canoes by Tsimshian traders who were maintaining a monopoly on the river. With the advent of European settlers, canoe-freighting was replaced by steam sternwheelers that became the main form of transport from 1860 to 1920 . Aboriginal crews were essential in guiding the ships through a narrow river canyon near Terrace enroute to Hazelton in this tight area which they knew intimately (Knight, 261-2). Fiske (1996: 175) noted that the Carrier women often joined the men in freighting as well as railroad construction, in clearing land for the settlers, and were often employees in domestic service.

When the opportunity for employment in the construction of the Grand Trunk Pacific Railway line arose in 1887 , preceded by railway surveyor camps beginning in the 1870 s, the Carrier workers took advantage of this opportunity (Knight, 163, 125). This "marked the beginning of truly massive capital investment and large-scale European settlement" in British Columbia, Knight (1996: 123) and Whitehead (1981: 41) pointed out, opening up the prairie and eastern markets to the west as well as to European settlers. Whitehead concluded (1981: 42) that this was the final phase of the influence of European settlers and government on the Carrier peoples traditional way of life.

By the 1920s, railway and other construction work opportunities for the Carrier people ceased. Employment in river, lake steamers, horse packing, and wagon freighting 
had also ended. Even the market for Carrier basketry and similar hand made products had declined. Some Carrier workers occasionally found employment in the commercial fishery, but eventually, the fish canneries became consolidated and mechanized, further reducing employment opportunities (Knight 1996: 321-2). A number of Carrier workers came to regularly work again in the forest industry, returning to the saw mills to produce lumber for export and their own needs.

\section{CHANGES IN THE ROLE OF WOMEN WORKING WITH MEN}

The proximity of traders to aboriginal women led to cross-cultural relationships through marriage changing the aboriginal traditional family relationship (McClellan 1981: 391). Because the marriages were often short lived, they came to be known as "country marriages" with a primary purpose of maintaining good trading relations (Fiske and Patrick, 2000: 148; Harris, 1997: 63; Van Kirk, 1980: 4).

Aboriginal women played a vital role in other ways. For example, they were active in teaching their language and in cross-cultural "diplomatic" relations at trading posts (Harris 1997: 65). They were also important as general workers around the posts (Harris 1997: 110). Traders' journals revealed that aboriginal women prepared food and made clothing for the traders, taught them methods of survival in the harsh climate of the Cordillera and provided a modicum of personal service in the community, especially as midwives. Aboriginal women provided connections in the new society to other allies in aboriginal communities. Important information was often channeled though these lines of 
communication by the women, who gained status in the eyes of their leaders (Barman 1996: 45).

\section{CHANGES IN CULTURAL EXPRESSION}

The practices in Carrier women's subsistence work, including their birch bark basket production, were adapted to accommodate emerging trade practices, their changing seasonal mobility and occupations, and new materials. Tobey (1981:379-81) stated that the manufacture of material culture was "often aligned by sex." Women had the responsibility for the manufacture of household items including basketry. Due to the Carrier women's traditional way of life, their material culture was made quickly, using local materials. In post-European times the materials used in the manufacture of the basketry were enhanced by trade (Leacock 1958, 1975, 1976).

McClelland and Deniston (1981: 386) and Tobey (1981:379-81) noted that the painted or carved wooden boxes of the Northwest Coast, produced by the more stationary Northwest Coast aboriginal people reflected their creative expression, while subarctic aboriginal peoples did not often decorate their portable objects. The subarctic Carrier basketry was made of light, flexible, readily available and easily transportable birch bark. It was suitable for the carriage and storage of food or clothing in their seasonal rounds. Yet, despite its utilitarian and disposable nature, it was still a vehicle for artistic expression, as seen in the $\mathrm{CMC}$ and $\mathrm{RBCM}$ collections. Carrier basketry was decorated in part with spruce root stitching. The roots used on the rim were often dyed black and/or 
red as a decorative decision made beyond the baskets' basic function. The basket walls were often decorated with incised designs on the birch bark.

Basket making was an essential activity in the pre-European aboriginal household economy. Baskets were used for berry picking, food preparation, storage of clothing and other materials (see Plate 1). Throughout the European period, Carrier basket maker's designs sometimes reflected the influences of European culture. This began with fur traders who brought trade goods in their attempt to endear themselves to the Carrier people. The traders offered European clothes, fabrics and decorations, and introduced the industrialized material culture that appealed to basket makers because it saved women time and labour (Tobey 1981: 347-50). Among other things, the subarctic basket makers were able to procure needles, awls, knives and scissors, thereby making production of their baskets easier (Helm, et al., 1981: 153). Barman (1996: 167-8) attributed the introduction of wool preparation and knitting, and the teaching of hand crafts to the early missionaries. New knowledge accompanied trade goods. For example, McClellan (1981: 391) found that kettles replaced traditional basketry production and sometimes baskets imitated shapes of metal kettles.

Knight (1996: 320) pointed out that in spite of acculturation the Carrier women retained some of their distinctive social and cultural traditions along with wage work. He (135) noted how the fur trade had replaced utilitarian and aboriginal artistic household material culture throughout the period of economic and social changes associated with Europeans, ca.1880-1920, and that basketry was revitalized with a new focus on earning income. 
Chapter Three / 41

Basketry became a commodity for trade or to hold trade goods. As manufactured goods took over the more utilitarian functions, basketry evolved eventually into a cultural trade commodity sold to and by European fur traders, and later by aboriginal people to collectors and travelers. Thus, basketry continued to be a vital aboriginal household economy in post-European times but for different reasons.

Knight (1996: 156) found that basketry was sold in specialty stores in Vancouver, New Westminster, and Victoria in the 1890's. There were baskets in their traditional shapes and design as well as novelty items such as coiled basketry serving trays made by Interior and Coast Salish women that catered to Euro-Canadians' Victorian and Edwardian tastes.

As European settlers moved into the subarctic regions, basketry production and styles were adapted to attract this new source of supplementary income, often in exchange for clothing. This adaptation can be traced from the 1850 s to the 1930 s in the birch bark basketry considered here, since the change affected both style and design. Later, in the twentieth-century, production diminished, and it continued to decline with the passing of the earlier and now elderly producers of basketry. Present day aboriginal cultural/historical re-enactment centers and museum gift shops market a small amount of subarctic birch bark basketry which is usually made by the very few remaining elderly basket makers or, in a few cases, by their descendants.

\section{Part II: EAstern Subarctic AlgonQuin/Montagnais People}

\section{Pre-European Times}




\section{GEOGRAPHY, ENVIRONMENT, AND SUBSISTENCE}

The eastern aboriginal people associated with this analysis live in the geographic and ecological region of Eastern Quebec and Labrador where the barren grounds of the northern tundra border the subarctic forest (see Maps 6-7). The eastern people had a uniform culture but three distinct dialects (Trigger 1978b: 799) in the eastern subarctic, according to Daniel Francis and Toby Morantz (1982:13-14) who described the influence of the natural environment on the Montagnais and Algonquin people in their study, Partners in Furs: A History of the Fur Trade in Eastern James Bay, 1600-1870. Meredith Black included the Algonquin people located in the lower Ottawa River region in her ethnobotanical study Algonquin Ethnobotany: An Interpretation of Aboriginal Adaptation in Southwestern Quebec (1980: 2). The Algonquin people with whom I had contact live at the confluence of the Rivière au Désert ${ }^{17}$ and Gatineau River near Maniwaki in Gatineau County, 85 miles north of Ottawa, Ontario (see Map 7).

James Tuck (1978:28) noted in "Regional Cultural Development, 3,000 to 300 B.C." (Northeast, Volume 15) that the Algonquin and Montagnais people depended on sustainable sources of food found in the environment of the Labrador/Quebec Boreal forest and the broad Quebec, Ottawa Valley/Riverine ecological region. Moose (Alces alces) and white-tailed deer (Odocoileur virginians) were their main sources of food. This diet was supplemented with edible plants and berries. In the more southern part of the region, sustenance was provided by the lakes, rivers and plains adjoining eastern Quebec and the Labrador peninsula (Trigger 1978b:799). Helm and Leacock (1971: 345-6) noted 
that the Algonquin, and Montagnais people hunted bear (Ursus), beaver (Castor canadensis) and porcupine (Erethizon dorsatum)

Algonquin and Montagnais women made hooks and gill nets from rawhide and from the inner bark of the willow (Salix nigra) tree for catching fish. They often chopped holes in the winter ice to set their nets and hooks. Fish weirs and traps were also used by the Montagnais and Algonquin people (Helm and Leacock 1971: 346, 234; Tobey 1981: 424).

Helm and Leacock (1971: 234) stated that the eastern Algonquin people cured animal hides and stitched them together for clothing and shelter. Strips of hide became laces and animal fur was sewn into tunics or capes. Bone and antler were made into tools such as knives, shavers and awls using stones or beaver teeth. The awl was used in the construction of the hide and bark items that included birch bark basketry.

Tipis covered with animal hides or birch bark were used for shelter throughout the subarctic region. Dome-shaped or ridge-pole lodges were constructed of birch bark (Tobey 1981: 390). Helm and Leacock (1971: 234) also found that the aboriginal people living within the middle or lower zones of the eastern subarctic relied on birch bark for many other uses from personal items and basketry to housing.

\section{Transitions for Eastern Subarctic Algonquin/Montagnais People}

\section{ABORIGINAL TRADING NETWORKS}

The Saguenay River in Quebec was the central trade route for the aboriginal traders, and later for Jesuit missionaries northeastern Canada. Tadoussac, at the mouth of 
the Saguenay on the St. Lawrence River, was an aboriginal trading center in eastern Canada that became an important fur trading center and Jesuit mission (Kenton 1927: 534$5, n .3)$

The Algonquin people from the Ottawa, Gatineau and Maurice drainage areas had a traditional trading relationship. The earliest reference to the habitation of the Algonquin people living along the Gatineau River was recorded by Champlain in 1613 (Black 1980: 16-7). They traded with the Montagnais Attikamègues people from the upper St. Maurice River. The Attikamègues people were eventually decimated by the Iroquois warriors and by subsequent smallpox epidemic. Following these disease epidemics and the Iroquoian wars, the Algonquin people were able to define themselves as a people and stabilize their band organizations. According to the Jesuit Fathers, the town of Trois Rivières had also been a traditional trading centre for the Algonquin and Montagnais people (Kenton 1927: 90, n.1). The Récollet missionaries were present there ca.1615-28. In 1634, Champlain established a fortified settlement as an outpost of defense to protect the fur trade from the Iroquois. Jesuit priest Paul le Jeune (1591-1664) spent his second winter in Canada with the Montagnais people to learn their language. He moved to Trois Rivières once that settlement was established (Kenton, 60, n.1) (see Map 8). Once the HBC Fort at Trois Rivieres was established in 1837, and they were assured of protection from the Iroquois, the Montagnais people traded down the Maurice River with the Algonquin people on the Ottawa and Gatineau Rivers. Previously, they had been trading westward with the Huron people because it was safer. During the inter tribal war years, they carried correspondence between the Jesuit missionaries. 
Post-European Influences

\section{ACCESS TO TRADITIONAL LANDS AND GOVERNMENT REGULATIONS}

As with the Carrier people, the federal government imposed formal arrangements on the Algonquin and Montagnais traditional band groups by establishing reserves. One was at Kitigan Zibi, near the European lumber town of Maniwaki. Another was allocated at Lake Temiskaming, close to the HBC posts. Aboriginal identity became linked to the reserve system and their seasonal mobility was reduced to a sedentary life (Helm, et. al. 1981: 152). Earlier, a Montagnais reserve had also been established near the HBC post at Lac St. Jean, with a summer fishing and trading camp near the HBC post at Tadoussac (see Map 8). Today, the Montagnais community remains concentrated in the Lac St. Jean area in central Quebec (see The Algonquins, Clément (ed): 1996). When Speck (ca.1941: 29) visited Kitigan Zibi and Lac St. Jean in 1935 , he noted that the local culture continued to be one of "hunting and wandering" from seasonal hunting camps.

\section{RELIGIOUS INSTITUTIONS AND PRACTICES}

Similar to the experience of the Carrier people, the Algonquin and Montagnais family traditions would break down due to a number of reasons, including the influence of Christian missions and later the residential school system. The impact of these institutions began in 1639. A source of insight into the Montagnais and Algonquin cultures at this time is found in the early accounts of the Roman Catholic Church. In An Ursuline of Quebec, 1639, Mahoney (1989: 24) noted the arrival and work of Marie de l'Incarnation, the Foundress of the Ursuline Order in Quebec. ${ }^{18}$ Marie's notes revealed that there were 
only thirty aboriginal inhabitants at Quebec City, although the explorers from France had arrived thirty years earlier (ca.1603).

She wrote that aboriginal people followed her ship along the shore of the St. Lawrence River to Quebec City, and when her party arrived at Quebec, the nuns found uninhabited aboriginal birch bark wigwams which they used for their own shelter (Mahoney 1989: 38, 41). They were subsequently used for their vocation in teaching until the Ursuline Order's convent and boarding school were constructed. Mahoney (1989: 33) stated that when hunting season began, the Montagnais and Algonquin men brought the women to the convent in great numbers. Thus, a relationship began for the aboriginal women with the Ursulines which included teachings in handwork as well as in faith (see Plates 9 to 11). As a result, the Ursulines influenced traditional ideas and designs that are reflected in the aboriginal basketry. ${ }^{19}$

Jesuit priests traveled into the Montagnais communities because they were interested in converting the members to Christianity. They recorded that the Montagnais people lived mainly along the 100 mile long Saguenay River (Kenton $1927: 11, \mathrm{n} .1)^{20}$ between Lac St. Jean to the St. Lawrence River, 120 miles northeast of present day Quebec City. They continued from Lac St. Jean to the Hudson's Bay region via river systems and portages. Thus, the Jesuits gave more attention to the non-sedentary Montagnais people involved in fur trapping than to those who stayed in populated communities such as Tadoussac and Lac St. Jean where the people were more readily accepting the Christian faith. 
POPULATION

Trigger (1978b) noted that even as the Algonquin and Montagnais populations were increasing, the size of their traditional band territories were reduced by the encroaching European settlers. The 1881 Census (Vol. 1-2) (see Table 1) recorded the number of aboriginal people living in each county and by community. If they did not live within a designated community, they were counted in the category of "unorganized territory."

TABLE 1: Number of aboriginal people in Quebec counties

\begin{tabular}{|c|c|c|c|}
\hline$\frac{\text { Ouebec }}{\text { County }}$ & $\begin{array}{c}\text { Community } \\
\text { (Aboriginal people) }\end{array}$ & $\frac{\text { Unorganized Territory }}{\text { (Aboriginal people) }}$ & $\begin{array}{c}\frac{\text { Total Aboriginal }}{\text { and Non -Aboriginal }} \\
\text { People Combined }\end{array}$ \\
\hline $\begin{array}{c}\text { Chicoutimi/ } \\
\text { Saguenay }\end{array}$ & Tadoussac (11) & 1,398 & 32,409 \\
\hline *St. Maurice & & 161 & 12,986 \\
\hline Ottawa & Maniwaki (225) & 320 & 49,432 \\
\hline Pontiac & $\begin{array}{c}* * \text { Temiskaming } \\
(955)\end{array}$ & & 19,939 \\
\hline
\end{tabular}

(1881 Census for Canada, Eastern Subarctic Region).

* no community designation

** although not designated as a community

By 1965 , the demographic data reflected an aboriginal population of 898 Algonquin people at Rivière Désert and 389 people at Lake Temiskaming while approximately 2,500 other Algonquin people lived off the reserves throughout the Ottawa River valley (Day and Trigger 1978: 797). 


\section{ECONOMIC CHANGE}

A decline in traditional material culture from hunting tools to basketry was noted by Daniel Francis and Toby Morantz (1982:167) as an effect of the European fur trade on the Algonquin and Montagnais people. On the other hand, Black (1980: 18) noted that European kettles and similar trade goods were found in the southeast Algonquin area at a very early date. The Gatineau River Algonquin people of the lower Ottawa River drainage area also traded at the HBC Fort Coulonge.

By 1663 , a trading post was established at Rupert House, at the southern end of Hudson's Bay. This was a successful attempt to bypass the control of the French and Scottish traders from Quebec (Helm et al., 1981: 150-2). In 1670, the Hudson's Bay Company was granted a Royal Charter. A year later, the competing French and Scottish traders from Tadoussac established a trading post at Lac St. Jean that would become the North West Company (hereafter NWC) operated by traders and lumbermen (Francis and Morantz 1982: 26, 35-6). Black (1980: 18) added that because the Lac St. Jean post gave higher prices for furs, the HBC established other trading posts in response. Francis and Morantz (1982: 133) and Black (1980: 18-19) stated that in 1676 the HBC re-opened the outpost at Fort Temiscaming at the northern end of Lake Temiscaming. The Jesuit Fathers had recorded the evidence of an early aboriginal occupation there, but the name Temiscaming had not been taken by any aboriginal people (Kenton $1927: 582$, n.2). In 1821 , the NWC was incorporated into the HBC.

An $\mathrm{HBC}$ post was established at the former Rivière Désert aboriginal community (Knight 2000), now the Kitigan Zibi community near Maniwaki (ca.1885) (Speck: 1915: 
2-3) (see http://www.kza/qc.ca).

The additional posts increased the number of European traders and settlers who moved among the Algonquin and Montagnais traders. The fact that a greater variety of expensive trade goods was available stimulated continued exploitation of the fur bearing animals, in some cases to near extinction, and depleted sources of food and trade for the Algonquin and Montagnais people. The European settlers made intensive use of local resources to the detriment of the Algonquin and Montagnais peoples regional hunting and fishing traditions. Moreover, with incursion by competing European trappers, the eastern subarctic aboriginal people had to make a renewed commitment to fur trading (though now in a smaller area) to support their subsistence base (Trigger 1978b: 799). European people continued to follow the fur trade in Canada by establishing homes nearby trading posts.

Helm and Leacock $(1971: 353,360)$ stated that disruptive changes for the eastern subarctic aboriginal families ca. $1670-1900$ were less problematic than those the Carrier people experienced because patterns of trade were more gradually consolidated over a longer period in time. By the mid-twentieth century, European industries offered wage employment to the families, providing primary or secondary sources of income. Forestry on the north shore of the St. Lawrence River became an economic mainstay for some of the Montagnais people. They were given permanent title to the land along the Bersimis River and subsequently built permanent homes. Fur trapping and forestry were the primary sources of income, although Helm et al. (1981: 156-7) found that due to language and literacy barriers, wage work was not possible for many. Through these changes in 
their way of life, the Montagnais people became further centralized and dependent upon the European economy. This involvement eventually evolved into the formation of permanent aboriginal communities. The traditions of communal sharing, family responsibility, and traditional relationships had to be adjusted, and a new social order based on individual and family-based survival practices ensued through relations with employers. This eventually led many aboriginal workers to migrate to urban centers. Speck (1915: 6-7) noted that at Lake Temiskaming the fur trade changed the dependency relationship of the traditional hunting family system. Aboriginal people came to depend on the external source of income and, as Leacock (1982:160) noted, the traditional collective group dependency ended and instead the nuclear family became the primary social unit. The women were now dependent on the male trappers. A long standing and complex debate over several years in the anthropological literature exists around the question of the Algonquin peoples traditional family-hunting territory system and its origins. ${ }^{21}$

Even traditional types of activity were directed to satisfying European demands. Knight (1996:283-5) stated that, in the 1890s, the Algonquin people were engaged in "hunting, fishing, building row boats and canoes, acting as guides for travelers, and working in lumber camps during the winter or log drives in the spring." While hunting and trapping continued into the 1920 s, logging camps and sawmill work were an important source of income in the region, when work was available. Some aboriginal men also worked as deck hands on the Great Lakes freighters.

Knight (1996: 287) reported that, by the middle of the nineteenth-century and for 
sixty years after, Algonquin men were working in the white pine lumber industry on the Ottawa River and its major tributaries. They were similarly engaged on the Gatineau River, a major transport route to the Ottawa River at the modern city of Ottawa, Ontario. He also noted (289) that the Montagnais people of Lac St. Jean worked at least seasonally in sawmills and the lumber camps during the late $1890 \mathrm{~s}$.

\section{CHANGES IN THE ROLE OF WOMEN AND CULTURAL EXPRESSION}

Like the Carrier women, the aboriginal wives of the Algonquin/Montagnais fur traders acted as interpreters around the HBC posts, and aboriginal women interpreters accompanied hunting and trapping expeditions (Knight 1996: 312-3). They typically made moccasins and clothing of animal hides for their families and then for the traders. They were also auxiliary workers or producers of "country food" for the company employees. Francis and Morantz (1982: 151-3) found that aboriginal women trapped game, fished and gathered berries for use at the company posts. At all $\mathrm{HBC}$ posts, the policy was adopted to educate the aboriginal children of the $\mathrm{HBC}$ employees in European ways, including principles of religion. They wanted their children to be prepared for employment with the company.

The production of birch bark basketry by Algonquin women was affected by the arrival of European settlers to their region. Speck (ca. 1941: 271-2) found that basketry production had declined and then expanded since the 1700 s. The lowest level of production was during the 1890 s because of the expansion of European activity, particularly in the forest industry in Quebec. The aboriginal people who lived close to the 
expanding industry were drawn from their traditional mode of living in hunting and trapping to work in construction camps. The Rivière Désert basket makers were especially affected in this way.

Following this period, a small increase in demand for aesthetic forms of work by the Rivière Désert women occurred. Speck (ca. 1941: 271) observed that, in periods of little employment or in the winter, the Algonquin women made birch bark basketry for sale to the new settlers. He saw this as a favorable outcome because the settlers appreciated the Rivière Désert basketry. Moreover, through exchange of commodities, both parties came to understand each other at least through art appreciation. As settlers began to enter the regions, the Rivière Désert basket makers responded by producing more basketry. Thus, the answer to the question Speck raised regarding survival or extinction of promising aboriginal art may have begun to emerge.

\section{Subarctic Basket Makers' Historical Transitions Compared}

The experience of the Carrier and the Algonquin/Montagnais basket makers and that of their families was starkly similar. They shared a subarctic climate with local variations in the landscape. Similar traditional practices were involved in seasonal rounds, harvesting local staple foods, primarily salmon in the west and moose and deer in the east. Their main tree species were birch and spruce, while pin cherry was a minor species used in their basketry. Similar methods and equipment were used in gathering of food, its preparation, preservation and consumption. Shelters were made of birch bark by both groups. Each basket maker took the time to decorate her basketry in forms and styles 
distinctive to her region and family. Each subarctic group also had its own traditional trading networks with neighbouring partners, although the goods traded varied according to the respective region. For example, eulachon oil was as unique to British Columbia as maple syrup was to Quebec.

The Carrier and Alongquin/Montagnais were each forced to move from their traditional beliefs and values to those of the dominant European society. Government structure and regulation were imposed through the Department of Indian Affairs, specifically through the Indian Act. In both regions, traditional lands that belonged to hereditary chiefs were divided into government administered reserve lands. Families were assigned specific lots by Indian Agents. Loss of traditional lands through encroaching European settlement took place gradually for the Algonquin/Montagnais people, while it was relatively suddenly for the Carrier people. Similar social consequences accompanied the settler population with the introduction of alcohol and firearms. Significant demographic crises occurred in both regions, primarily due to European introduced epidemics of disease.

In both regions, the European fur trade companies created an economic dependency in a monopolistic credit system for furs exchanged for European goods, while a government policy required registration of trap lines. Trade followed in conjunction with settlement by newcomers as they moved first into the east and later into British Columbia. A wage economy was introduced in fishing and forestry local industries in British Columbia, and similarly in Quebec, local forestry industries furthered economic dependency. Carrier women were engaged to some extent with their husbands and 
colleagues in commercial fisheries and canneries, railroad construction as well as roads and bridges, clearcut logging and sawmill industries, seasonal agricultural work and as crews on sternwheelers and freighters.

Subarctic aboriginal women in the two respective regions also shared similar experiences through cross cultural personal relationships as well as through employment in domestic services, midwifery, teaching languages, cross-cultural diplomacy at trading posts, and as general workers around trading posts involved in provisions of food and clothing.

The government decided that aboriginal children in Canada, including Carrier and Algonquin/Montagnais children would attend residential schools in an ongoing program of civilizing, with the direct involvement of the churches in managing the schools who had their own programs of missionization. New knowledge was learned in using trade goods and domestic teachings from the missionaries while traditional production capacity in the family and opportunities for teaching traditional knowledge and culture including basketry were eliminated.

By the 1920 s, employment opportunities continued to change. Aboriginal production of basketry increased as the demand for subarctic basketry developed in the settler society but for a different purpose and consumer. Basketry production was adapted to accommodate those emerging trade practices, new materials, and new consumers. In the transition, basketry production took on the new purpose of earning income. 


\section{Summary}

The traditional Carrier peoples social, economic and political systems gradually disintegrated during the post-European period. The arrival of the settler population brought with it entrepreneurial enterprises. Settlers entered the Carrier territories and established private agricultural practices and other businesses. By 1916, all lands other than the reserve lands set aside for aboriginal people were owned by settlers and the crown.

Governments and church leaders supported settler ventures, built provincial infrastructure for development, and applied regulations and enforcement in their own interest. Carrier children were taught a European curriculum in newly established residential schools such as Lejac Residential School near Vanderhoof or St. Joseph's School to the south, based on European values and attitudes to living.

While adapting to these changes to some degree, the aboriginal population exhibited dissatisfaction with this system, particularly with the imposed land reserve system. Through government regulations, the Indian Reserve Commissioners assigned reserves throughout much of British Columbia (Knight 1996: 108). This policy was never accepted, and widespread land claims by First Nations began to emerge at the beginning of the twentieth century. In 1911, the British Columbia government reclaimed reserve lands it deemed not in use and identified them as "cut-off lands." More than 30,000 discrete areas were lost (Knight, 1996, 108).

Against this background of acculturation and a new economic framework, Carrier and Algonquin/Montagnais basketry is examined through a formal stylistic analysis in the 
Chapter Three / 56 next Chapter with a view to identifying regional and personal design characteristics. 


\section{Chapter Four}

\section{STYLISTIC ANALYSIS OF BIRCH BARK BASKETRY}

This chapter is in four sections. In the first section, the general methodology used in the formal analysis of the basketry is explained. In the second section, the provenance of the basketry under consideration is discussed The third section contains the formal analysis of the Carrier and Algonquin/Montagnais basketry in the collection with a precise explanation of the methodology used in the analysis, including the typology of the collection. In the final section is a discussion of the results of the analysis, including the identification of similarities and differences between Carrier and Algonquin/ Montagnais basketry, and suggestions, if any, of regional identity that were found in certain baskets.

\section{Methodology Used in the Analysis}

In 1883-4, Otis Mason delineated a methodology for the study of basketry in Basket-Work of the North American Aborigines (Smithsonian, 1885: Vol. 2). Mason distinguished individual baskets using ethnographic materials with a descriptive glossary and a preliminary model for classification and criteria. His was the first attempt at a limited taxonomy of basketry on a regional basis, one that subsequently stimulated further studies in basketry and analysis. In the twentieth century, Adovasio developed a typological methodology in Basketry Technology: A Guide to Identifications and Analysis (1977). He pointed out (1) that while baskets are three dimensional, they are treated as a single object because of the overall technique of their construction. 
The stylistic analysis in this thesis utilizes a standardized description and interpretation process developed by Adovasio. For each basket, it involves four procedures: (a) identification of the form, (b) identification of particular attributes; (c) analysis of the attributes and their combinations, and (d) an interpretation of the results. This approach has been utilized in organizing the data and is developed and discussed later in this chapter.

The primary methodology was suggested by Sally McLendon in Preparing Museum Collections for Use as Primary Data in Ethnographic Research (1981: 201-28). Her methodology was essential in selecting the baskets for detailed study. She proposed that museum material can be considered to be primary data when relevant information such as the provenance of the object(s) is extracted from museum records and is accompanied by a photograph taken by the researcher to verify the object(s). Thus, the provenance verifies the history of the basket and the image facilitates discussion of the stylistic analysis. Utilizing McLendon's methodology, information for each basket was catalogued from the museum acquisition and archival records, with the photographic record and the stylistic analysis for each basket completing the inventory. The result was an analysis made through a process of standardized description and interpretation. This efficiently facilitated the division of the baskets into analytical categories for comparison among specific groups according to Adovasio's methodology (1977: 33).

The second element of the methodology was field work. In 2000, I spent ten days in some Carrier communities in the northern interior of British Columbia. This gave me an experience of the physical environment in summer, and a visual and cultural sense of the 
communities from which many baskets under analysis were collected. In addition, I gathered information by interviews with local people in some of those locations. In the town of Hazelton, I visited the municipal archives and library, reading correspondence and records that were of interest. I also visited two First Nations' cultural centers. One was in Prince George, where I found birch bark basketry by Neskolinth Secwepemc Harold Thomas for sale. The other was K'San Historical Village, the Gitksan peoples museum in Hazelton. There, I found Carrier basketry for sale as well as on exhibit by Noleen McQuary, the daughter of informant Bernie McQuary of Nadleh Whuten (Nautley Reserve) in the central Carrier region. Old and new Carrier basketry was also exhibited at the re-enacted historic Fort St. James site on Stuart Lake (see Map 4).

With respect to Algonquin birch bark basketry, I had conversations with two basket maker/vendors, one a man, the other a woman, at the $\mathrm{CMC}$ during art and craft demonstrations and sales (ca.1998-99). Similar basketry was observed at cultural centres, fairs and aboriginal pow wows in Ottawa, Ontario and in the province of Quebec.

In keeping with Barrett's (1908: 133-276), Bunzel's (1929), and McLendon's (1981) methodologies, I prepared a catalogue of images from photographs taken of the basketry (see Appendix Three, Basketry Catalogue). I chose to photograph the basketry as part of my methodology because it enabled visual study and comparison for accuracy. It also confirmed that each basket matched its description and analysis for presentation to the reader. In keeping with O'Neale's method (1932), the photographs facilitated discussion with two contemporary basket makers in my interviews (July 29-30, 2000), and assisted in identifying certain baskets by basket maker and region or community. The 
information available for each basket, including respective museum catalogue numbers, dates collected, collectors, and measurements for each basket is included with each image in the Basketry Catalogue (Appendix Three). Detailed ethnographic notes pertaining to the RBCM baskets are found in Appendix Five.

Social, historical and economic data were found in files of the Department of Indian Affairs and Northern Development. These included Indian Agents' records, Letterbooks, District Reports and correspondence. At the RBCM, I studied the ethnology accession log books, files, and correspondence files. The British Columbia Provincial Archives yielded details from vital events records, textual and visual records, and vertical files relating to the collectors of the basketry in the RBCM. Field notes and correspondence of some of the collectors were also examined, notably the log books and diaries of Frank C. Swannell (1880-1969), as well as the log books, diaries and notes of retired physician and amateur ethnographer Charles F. Newcombe (1851-1924).

Since I was unable to study archival material for Algonquin baskets in the Department of Indian Affairs files, Frank Speck's research (1937, ca.1941) was the principal source of information for the Algonquin and Montagnais basket makers. He wrote an extensive account of his research and findings during his travels in the Quebec communities of Temiskaming, Rivière au Désert, and Lac St. Jean where he collected the basketry in the CMC collection being considered. In addition, my personal experience while I lived near the Algonquin (Kitigan Zibi) and traveled through Montagnais (Tadoussac) communities overlapped with the research noted above. 


\section{PROVENANCE OF SUBARCTIC ABORIGINAL BASKETRY}

Catalogue information about provenance enables the basketry to be situated in its historical and ethnographic contexts. The provenance record of the $\mathrm{CMC}$ collection is relatively complete, and can be taken from the collector's field notes. However, that of the RBCM basketry is mostly unknown because of a lack of field notes.

For the majority of the baskets, the acquisition dates and information provided by the collectors and recorded in the catalogue notes from the records of the CMC (and to a limited degree the RBCM) helped to place the basketry in its historical context. In one instance involving five Carrier baskets by one maker, archival research contributed considerably to supplementing the limited information in the collection records. Archival research assisted in obtaining some information for most of the RBCM basketry (see Appendix Five, Ethnographic Notes).

\section{Collecting Carrier Basketry}

In British Columbia, Carrier basketry was collected from the Wet'suwet'en Carrier region (see Map 3) at Hazelton (also in the vicinity is Kisgagas [sic]), Hagwilget, and the upper Skeena River). In the central Carrier region, baskets were collected at Stony Creek, Stuart Lake, Fort Fraser and Nautley Reserve (Nadleh Whuten) in the vicinity of Vanderhoof (see Map 4). In the southern Carrier region, baskets were collected near Bella Coola. Beyond the Carrier territories, subarctic birch bark baskets, likely Carrier, were collected from Masset, Queen Charlotte Islands, unspecified northern Athapaskan and Stikine River areas, and Vancouver on the lower mainland of British Columbia. 
According to museum records, 82 Carrier birch bark baskets were collected from Hazelton and vicinity, 21 were collected from central Carrier communities in the vicinity of Vanderhoof, while three were collected from Bella Coola near the southern central Carrier area. In addition, 35 Carrier birch bark baskets are from unidentified locations. The analysis has enabled regional identity of a few of the baskets to be determined.

The collecting of Carrier baskets began in 1852, with most collected between 1909 and 1925. The principal collectors between 1909 and 1925 were British Columbia land surveyor Lt. Frank Cyril Swannell; Adrien J. Morice OMI of Stuart Lake; and from the National Museum of Canada, archaeologist Harlan I. Smith, ethnologist C. Marius Barbeau, and anthropologist Diamond Jenness. The remaining collectors were private citizens in British Columbia who donated their small collections to the RBCM between 1892 and 1991 (see Appendix One, Tables 3 to 5 for further details, and Appendix Five, Ethnographic Notes).

Collecting aboriginal material culture was encouraged by the newly defined mandate for the RBCM in British Columbia, proclaimed in the 1913 Provincial Museum $A c t$

"giving the museum formal operating authority and defining the objectives as follows: to secure and preserve specimens illustrating the natural history of the Province, to collect anthropological material relating to the aboriginal races of the Province" (www.http://rbcml.rbcm.gov.bc.ca).

The mandate encouraged ethnologists and museum staff as well as private citizens to contribute aboriginal material culture to the museum's collection. 


\section{Collecting Algonquin and Montagnais Basketry}

In contrast to Carrier baskets, Algonquin and Montagnais baskets in the study were collected by only two collectors, both of whom had ethnological training. Edward Sapir acquired Algonquin and Montagnais baskets on behalf of the museum between 1911 and 1913 in approximately the same period as many of the Carrier baskets. Frank G. Speck collected birch bark baskets from the Algonquin and Montagnais basket makers between 1912-13 (see Appendix One, Table 6) and sold them to the Geological Survey of Canada. ${ }^{22}$ Speck later utilized his knowledge of the Carrier birch bark basketry when he was employed by the University of Pennsylvania. ${ }^{23}$

Speck studied basketry during his field work with the Montagnais people of Lac St. Jean, the Algonquin people of Lake Temiskaming and Rivière Désert near Maniwaki. He noted that the knowledge of birch bark basketry at that time relied on objects found in museums often lacking sufficient information. Yet, although he referred to basket makers with whom he interacted, he did not attach specific names of basket makers to the baskets that he sent to the National Museum. This is attributable to conventions that existed within anthropology at the time regarding the relationship between craft and 'art' or other issues. Speck studied several hundred baskets from the Lac St. Jean area and distributed them to eight museums in North America and Denmark (1937: 48-9).

Speck observed that the mobility of the Montagnais people took its toll on the survival of early basketry. He discovered that baskets were casually left behind for later use when the Montagnais people returned to their winter hunting camp, and noted (95-6) collecting basketry from these empty camps. 
On June 6, 1912, while in British Columbia, Harlan Smith made an appeal to Sapir to provide funds for Speck who was leaving for Quebec to collect specimens. Smith pointed out that Speck would be in remote areas of Quebec and that "he is a careful collector."24 He said that Speck hoped that the collected material would go to “individuals or institutions such as Sapir's who would value the material rather than just corner the [collecting] market." Smith assumed that Sapir's point of view closely resembled that of Speck since they had the same training and were very close friends (see Pulla, 2000).

Thirty six birch bark baskets were acquired from the Rivière Désert Band in 1912 and 1913 (see Appendix One, Table 6). Speck returned to the Montagnais community and with further material gathered from his informants, including the characteristics of their basketry, he published his findings in 1937. In his subsequent monograph in ca. 1941, he noted (234) that a "close resemblance exists between the manufacture and decorations of the Algonquin basketry and that of the Montganais baskets of [Lac St. Jean]."

\section{STYLISTIC ANALYSIS OF SUBARCTIC BIRCH BARK BASKETRY}

Adovasio (1977: 4) found through examining archaeological and ethnographic data that no two populations appeared to have manufactured precisely the same forms of basketry, regardless of the type of basket, and that minor differences were accounted for by local and culturally determined factors. Similarly, Laforet (1984: 246-9) stated that, while neighbouring aboriginal basket makers in northern British Columbia often had similar technical traditions in construction and design, it was rare to find examples that were 
identical. In every region, basket makers developed methods of manufacture and features of form that were distinctive. Moreover, it is possible to see beyond broad similarities of dependent styles in basketry from within the local community, sub-region, or regions of neighbouring peoples to establish stylistic differentiations within each ethnographic group. Through the proper analysis, description and interpretation of basketry, much information about the community and even individual basket makers can emerge. As Bruce Bernstein (1998: 75) stated in a catalogue for an exhibition at the Metropolitan Museum of Art "while a [basketmaker] worked within the confines of her tribe's basketry traditions, she also [worked] her own artistic hand into each basket, bringing change, innovation and vitality to the art form over centuries by introducing new designs, shapes, and materials."

A description of a stylistic analysis is reflected in Laforet's (1990: 286) comments:

"A basketry style is a set of ideas echoed in practice until the ideas themselves are forgotten. They are forgotten, but captured in process and product and remain there, to be decoded when required. [Moreover,] the basketry style ... encodes the identity of a people, [and] by following differences between styles encodes differences between groups."

Furthermore, Laforet pointed out (n.d. (b)) in referring to all types of aboriginal basketry made in British Columbia that form, materials, technique and decoration are the elements to be examined for attributes that in combination constitute style. Consideration of these salient features in the construction of basketry can help identify regional styles.

Salient features of birch bark basketry are (a) the material used in construction and decoration of the basket, (b) the shape or form of the basket, and (c) the techniques of manufacture, i.e. details of the fold, cut, and stitching, and composition of the rim, and (d) decoration, i.e. analysis includes the materials used in stitching decorative designs on the rim and/or ends. Notable design elements may be found on the wall or field of the basket 
and base decoration, if any, created through incised designs (see Plate 12). Analysis of these characteristics enables the development of formal classification and possibly attribution to a particular region and/or basket maker. For example, through this approach Laforet (1990) was able to make the attribution of certain woven hats to particular Haida weavers.

Following Adovasio's model, analysis of the attributes of the basketry in this study determined the major groups, sub-groups, and sub-classes of shape or form. Illustrations of representative examples of the birch bark basketry are provided throughout the stylistic analysis. The reader is also referred to the Basketry Catalogue, (Appendix Three).

\section{Stylistic Analysis: The Method}

The stylistic analysis organizes, details of the form of the base, walls and mouth, the materials used for construction and decoration, the method of stitching, and the decoration and design. The analysis yielded four main types represented according to their shape or form, and several sub-classes based on particular variations.

An element important in the analysis of birch bark basketry are the matching points on the ends of each basket. This refers to three elements of design and construction that I found:

(i) cut location, below or near the bottom, mid-way at the middle of the basket, or close to the top. This detail is particularly relevant when the precision of the cut is the foundation for the pattern of the design.

(ii) fold direction, the bark was folded either in a left-over-right direction, or a right-over-left direction before being stitched. The description of this as a design element is noted if the quality of the cut and fold was very precise. 
(iii) stitching, the nature and quality of stitching at the matching points completes the design elements (see CMC VI B 66 in Appendix Three). High quality of workmanship is manifested in the precision and consistency of stitching design.

Rim design, the elements that are created by a repeated series or pattern of stitches to one inch below the mouth of the basket, and may

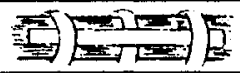
include dyed sections, or beading (Fig. 1).

Base decoration is created through incised designs.

\section{CARRIER BASKETS}

A complete list of the baskets studied is provided in the Master Table (Appendix Four). The first group of baskets studied was from British Columbia. The primary collectors, i.e. those who collected more than ten baskets each were archaeologist Harlan I. Smith, anthropologist C. Marius Barbeau, and physician Oswald Meredith Jones. Three Carrier basket makers identified were Adele (Wet'suwet'en) CMC VI B 62 to 66; Carrier, Agnes George, (Nadleh Whuten), RBCM 7070, 8738, 9258, 14525; and Madeline Johnny, (Sai'k'uz Ts'eke), RBCM 4485, 4486.

There were 137 Carrier baskets studied, including four innovative forms (baskets that fall outside the norm). The majority of the baskets proved to be in two main forms. 94 baskets were in Form $A$, a tall basket with an open mouth, and 43 baskets were in Form $B$, a shallow open tray. There were variations in each form (see Appendix One, Tables 7 and 8 ). 
TABLE 1: Main Forms and Variations of Carrier Basketry

\begin{tabular}{|c|c|c|c|c|}
\hline Form A: & $\begin{array}{c}\text { Form A.1 } \\
\text { Concave Mouth }\end{array}$ & $\begin{array}{c}\text { Form A.2 } \\
\text { Oval Mouth }\end{array}$ & $\begin{array}{c}\text { Form A.3 } \\
\text { Round Mouth }\end{array}$ & Total \\
\hline & 40 & 19 & 35 & 94 \\
\hline Form B: & $\begin{array}{c}\text { Form B.1 } \\
\text { Rectangular Base }\end{array}$ & $\begin{array}{c}\text { Form B.2 } \\
\text { Square Base }\end{array}$ & & \\
\hline & 28 & 15 & & Total \\
\hline
\end{tabular}

The Carrier baskets were made with similar materials in construction and decoration. Included were birch bark, willow rod, spruce roots, goose quills, horse hair, cherry bark or dyed spruce roots, incising, and occasionally hide or European textiles such as wool, string or yarn. All Carrier baskets had a willow rod fastened on the inside with spruce root stitching for reinforcement. Methods of stitching varied according to each form and are explained with the examples below.

In constructing a basket, a subarctic aboriginal basket maker began by cutting a pattern (see Plate 13) from the bark according to the planned use. Each end section was first folded upward, Neskonlith Secwepemc elder Mary Thomas explained (April 25, 2001, Personal Communication). ${ }^{25}$ A left-handed basket maker might possibly fold the top section of the end piece left-over-right; or a right-handed basket-maker right-over-left. Moreover, Mary Thomas explained the construction and stitching of the Carrier basketry "they have a different pattern than the Shuswap ... the way the pattern on the ends are. The ones from the Carrier, they come from the corner, straight up to the edge [see Fig. 5.] I just have to take a look and I can say: oh, I know who made that. They have particular designs." 26 
Mrs. Thomas also noted a unique characteristic of the Carrier basketry. A "jog" pattern is cut at the bottom of the upper section (see Plate 12 (c)) for either functional reasons such as to secure the seam, or for decorative purposes.

A definitive and illustrated discussion of form, technique and decoration of birch bark basketry for the southern interior Nlaka'pamux people of the Fraser River valley and the Secwepemc basket makers was written by ethnographer James Teit (1909: 477-80; 764). Teit's work demonstrated and confirmed Mary Thomas' explanation of the traditional Secwepemc construction of birch bark basketry. The illustrative figures (Plate 12) that are used in the thesis discussed here are taken from Teit's work (1909: 478-81). With slight variations that Teit demonstrated, the Shuswap patterns were similar to the shape or form of the Carrier basketry. Further references to Teit's work are made in the analysis.

In the subarctic region of British Columbia, the traditional time of year to gather bark was after the sap had stopped running, according to contemporary basket maker Madeline Johnny (July 29, 2000, Personal Communication). The reason was that the bark could not be incised if taken when the sap was running, she explained, because it must be dry, and if removed from the tree after the sap had run, it's finish is rougher and easier to incise. The design shows up better, she noted. Mary Thomas (April 25, 2001, Personal Communication) confirmed this. She said

"around about June and only for a few weeks you can get the birch bark. When the sap starts to go down, it slowly loosens the bark. When the sap is just starting to go up around about June, it will only last for so long when it will start to stick again." 
Madeline Johnny made a practice of flattening the bark with a weight and then storing it in a cool place. It would bend easily but not curl when she was making her basketry. Mary Thomas agreed the bark had to be kept cool. With today's conveniences, Mrs. Thomas keeps her bark in an outside chest freezer. The basket makers also noted that the roots were gathered during the summer months. Spruce roots are ideally removed from sandy soil with few rocks because many rocks may cause defects in the roots (Turner 1996: 21). Madeline Johnny peeled the spruce roots that she used to stitch her baskets, and sometimes dyed them then with natural plant dyes before European dyes became available.

\section{CARRIER FORM A. 1}

The principal feature of Form $A$ is a tall basket with an open mouth and a variation in the shape of the mouth. Forms A.I-A.3 (Figs. 2-4) are distinguishable by the varied shape of their mouth, i.e. concave, round, and oval, while the upper and lower end stitching methods and designs were similar in each form. The stitching method employed on the upper ends of Form A.l (Fig. 2), was single or double stitches, sometimes incorporating either cross stitches, that

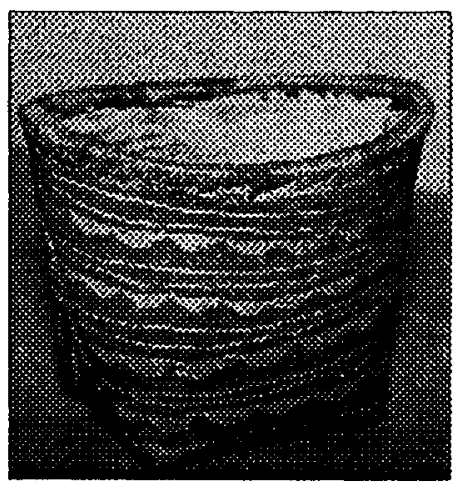

FIG. 2. Carrier. Form A.1. CMC VI B 63. Hazelton. C.M. Barbeau. 1920-21. L. $15.5 \mathrm{~cm}, W .12 .5 \mathrm{~cm}$, H. $13.5 \mathrm{~cm}$.

is, two stitches cross angled over each other with a tiny stitch in the centre to secure them, a chevron, or a zig-zag design. The method of stitching on the lower ends of the baskets was in one of three patterns. The most common pattern was composed of tight stitches 
that ascended from the mid-point, top, or bottom of the previous stitch. Second, the stitches were short and separated, ascending from the mid-point of the previous stitch. Third, the stitches may be of medium length, ascending from the mid-point of the previous stitch, either in a zig-zag design or simply following the seam. They may have continued across the top of the jog seam, a design feature of interest in the middle part of the end of the basket.

An attractive rim design pattern was created with tight stitches from short to long, usually four or five, ascending or descending from right to left, or left to right. The rims of the baskets were stitched through a hole previously made with a tool called an awl, under and over the splint. The Carrier baskets did not have lids. An additional decorative element was often incorporated on the rim using dyed spruce roots stitched at the centre and the end in four locations with equivalent spaces between. In addition, a beading (Fig. 1) pattern may also have been added to the rim using materials mentioned above.

Decoration on the design field or wall of the basket often included a variety of incised elements. These were either vertical, horizontal, diagonal, wavy lines, short slashes, half-triangles, or a combination of these elements that were often created in bands forming patterns across the design field. Or, there may be representative images of plants, animals, or astronomy motifs. If the walls did not have any decorative elements applied they are considered to have a plain field. 


\section{CARRIER FORMA.2}

Included in Form A.2 (Fig. 3), a tall basket with a round mouth, is end stitching in single or double stitches that also sometimes incorporated cross stitches, a chevron, or zig-zag design. The method of stitching on the lower ends included the same variety as the forms above, although occasionally cross stitching occurred across a wide jog seam shown in Fig. 3.

The rim design elements in Form A.2 were made in an attractive pattern of tight stitching with short to long stitches,

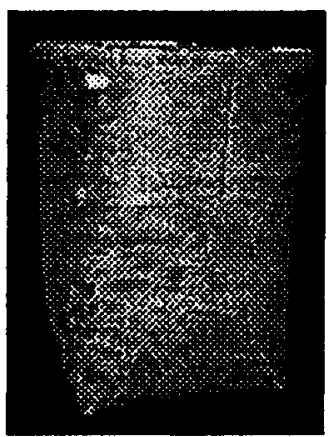

FIG. 3. Carrier. Form A. 2. CMC VI B 138. Stuart Lake. Rev. A.G. Morice. 1892.

L. $37 \mathrm{~cm}, W .31 \mathrm{~cm}$, $\mathrm{H} .40 \mathrm{~cm}$.

usually four or five, ascending from left to right. The similar decorative element, dyed spruce root sections, was often incorporated on the rim as well as the beading technique using materials mentioned above. Decoration on the design field or wall of the basket was similar to the Form A.I group. These were either vertical, horizontal, diagonal or scalloped lines or half-triangles, or combinations applied in bands across the design field. There may have been images of plants, animals, or astronomy motifs.

\section{CARRIER FORM A. 3}

With Form A.3, (Fig. 4), a tall basket with oval mouth, the upper and lower end stitching methods and designs were similar to Forms $A .1$ and $A .2$. The rim design elements in Form A.3 were also made in an attractive pattern

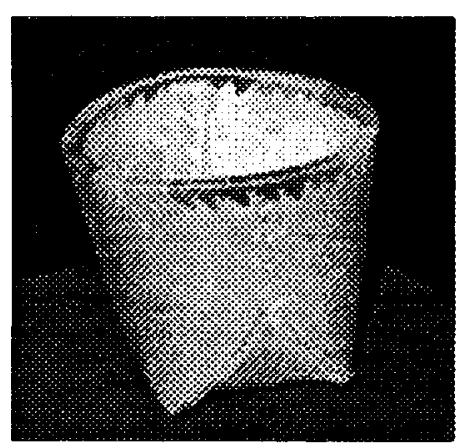

FIG. 4. Carrier. Form A.3. RBCM 11072. Mrs. Melba Menzie Coll'n.. $\mathrm{n} / \mathrm{a}$ 
of tight stitching with short to long stitches, usually four or five, that ascended from left to right. A similar decorative element in dyed spruce root sections was often incorporated on the rim as in Form A.I and A.2, as well as the beading technique using materials mentioned above. There were also some baskets with decorative wall elements on Form $A .3$ in a variety of incised elements as described above.

\section{CARRIER FORM B.I}

The main distinction between Form $B$ and the Form $A$ group was in the lower height, an often rectangular base, and a difference in the construction of the end seams. In

Form B.l (Fig.5), the end seams were cut from the base of the basket to the rim, then folded inward from each corner to

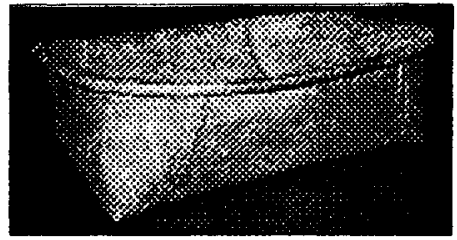

FIG. 5. Carrier Form B.1 CMC VI B 61. Stuart Lake. Rev. A.G. Morice. 1892. L. $40 \mathrm{~cm}, W .32 \mathrm{~cm}, H .13 \mathrm{~cm}$. either the end or the side of the basket In other words, there was a straight seam from the base to the rim that did not have a jog cut. The stitching method on the end seam was consistent small separate stitches that ascended from the top or middle of the previous stitch, sometimes cross stitches, or large random stitches.

The rim design in Form B.I was created with a combination of symmetrical short or long alternating, regular or irregular stitches around the rim. As in the above forms, the rim often had dyed spruce roots at the centre and the end in four locations with equivalent spaces between, as well as single or double beading using the same variety of materials, and, similar decorative incised motifs. 


\section{CARRIER FORM B.2}

Form B.2 (Fig. 6) was distinct with a broad open mouth and a small square base. The materials used in construction and decoration were similar to the above forms. Because of the shallow form of this basket, the seams and round mouth that incorporated the splint, formed a thick platform for an attractive pattern, especially the beading

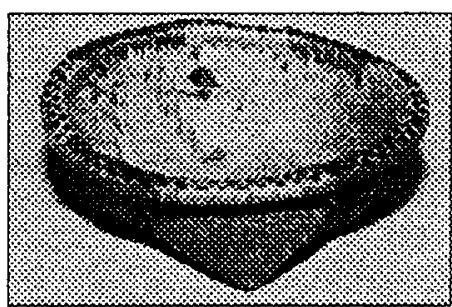

FIG. 6. Carrier. Form B.2 CMC VI B 116. Hazelton. H.I. Smith. 1925.

L. $11.5 \mathrm{~cm}, W .11 .5 \mathrm{~cm}$, H. $.5 \mathrm{~cm}$ technique. In another instance, textile fabric was incorporated under open stitched roots.

If there were decorative elements on the design field or wall of this form of basket, they were similar to the above noted forms and included geometric elements, often in bands, or representative images of birds. The base may have had a double " $x$ " and horizontal line incised through the middle of an " $x$ " on the design field.

\section{Innovations in Carrier Basketry}

INNOVATION 1 (Fig. 7). This Carrier birch bark basket had a square base with inward sloping walls and a small round rim. The materials used in construction and decoration were birch bark, willow rod, and various colours of dyed spruce root at the centre and the end of four locations with equivalent spaces between. The stitching method was a single seam made with a basting stitch that was similar to lacing. The rim was stitched mainly with short stitches and occasionally long ones. While we refer to this particular basket in the category of

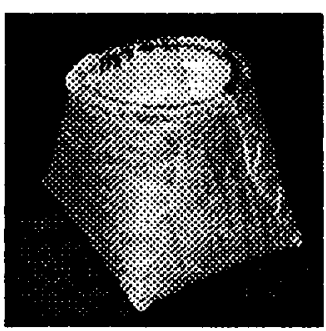

FIG.7. Carrier. Innovation I. CMC VI B 71. Fort Fraser. Diamond Jenness. 1924. L. $14.6 \mathrm{~cm}, \mathrm{~W} .13 \mathrm{~cm}$, $\mathrm{H} .12 \mathrm{~cm}$. 
innovation, Teit (1909: 481-2) referred to this form with those collected on the Lower Yukon River as well as being produced by the Shuswap people. He further noted they were found in eastern North America. We have examples used by the Algonquin/ Montagnais people (see CMC III L 56-7, and Fig. 11).

INNOVATION 2 (Fig. 8). This Carrier birch bark basket had a square base with straight walls and a round rim. It was part of a set of three nested baskets. The materials used in the construction were birch bark, willow splint, spruce root, and paint applied to the spruce roots. There was no stitching on the sides. Instead, the bark was folded rather than cut and affixed within the rim stitching. The

rim stitches were mainly short with longer ones every third or

FIG. 8. Carrier. Innovation 2. RBCM 10530c. Stikine. C.F. Newcombe. Before

1961. n.a.

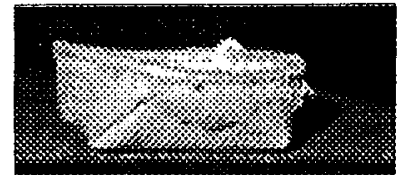

fourth stitch. At one end was a painted section while on the sides there was an added piece of bark cut in a curved scalloped pattern. The rim was stitched mainly with short stitches and occasionally long ones. Teit (1909: 481) also noted the strip of bark added to the outside of the rim of birch bark basketry was used as reinforcement. C.F. Newcombe attributed this basket to the Stikine area which is northwest of Hazelton. The nesting series of baskets may be a result of cross-cultural ideas between Europeans and aboriginal design and style. 
INNOVATION 3 (Fig.9). This Carrier birch bark basket had a circular, separate base with straight walls expanding to a round rim. The materials used in the construction were birch bark, willow splint and spruce root with paint applied to the spruce roots. The stitching method employed was separate short diagonal stitches over each of the three vertical seams. The outside seam had separate diagonal stitches while the overlapping inside seam had the same stitches but were very tiny. The separate circular bottom was stitched with a pattern of long and short stitches.

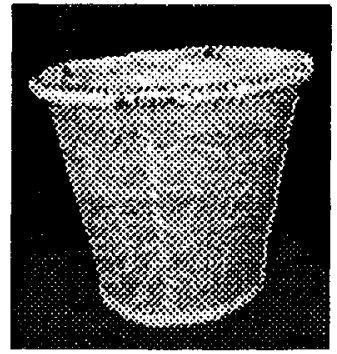

FIG. 9. Carrier. Innovation 3. RBCM 14525. Fort

Fraser. P.L.MacNair purchase for Museum at K'San Sales, Hazelton. 1974. H. $20 \mathrm{~cm}$, Dia $21 \mathrm{~cm}$.

This was a very decorative birch bark basket. Decoration on the rim included four open sections of cherry bark over which were cross stitches in an open pattern. The remainder of the rim sections had even length stitches and double beading with cherry bark. On the design field, the upper field had two bands of upright or inverted, solid or hollow scallop motifs incised from which an occasional vertical curved floral "V" motif appeared either above or below the center. The middle and lower fields had scattered floral motifs.

INNOVATION 4 (Fig. 10) This Carrier birch bark basket also had a circular separate base with straight walls and a round rim. The materials used in construction and decoration were birch bark, willow splint, spruce root and dye. The method of stitching on the basket created an attractive pattern. A pattern of cross stitching

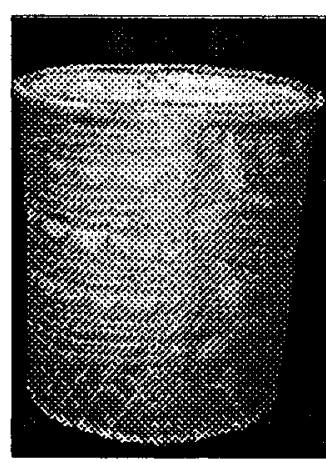

FIG. 10. Carrier. Innovation 4. RBCM 18242 . Masset. Gift of Henry Edenshaw to Mrs. Dorothy Sherwood. 1919, $\mathrm{n} / \mathbf{a}$ 
secured the vertical side seams. A pattern on the rim was created with sets of four ascending stitches to the left around the circumference of the rim. The base was fastened to the walls with consecutive cross stitches.

The rim decoration consisted of dyed spruce roots at the centre and the end in four locations with equivalent spaces between in two colour systems. One side of the rim had dyed sections of red, green, and red, while the other had sections dyed red, natural, and red. In addition, dyed spruce root beading was applied at the middle and end points of the rim. The design field or wall had an incised pattern of four bands. Three bands had four lines and a series of inverted scallop motifs on the underside except for the last set which had a series of cross-hatched lines to the base. Side two had a pattern of representative flowers and leaves on a stem across the entire field.

\section{Discussion of Carrier Stylistic Analysis}

We are now able to examine these baskets in the context of the data taken from the museum's accession records and the collection history. Teit's work provided an opportunity for comparison of Secwepemc and Carrier basketry.

Teit noted (1909: 477-80) that there was a great amount of birch bark basketry of superior quality available, ca.1900, and that most types were very popular. Birch bark basketry was used by all of the Secwepemc people in many different ways. Moreover, Teit suggested the northern or upper Nlaka' pamux basket makers developed their birch bark basketry technology further than the Secwepemc basket makers did. 
Many Tsilhqot'in people emigrated in pre-European time into the southern Carrier community of Alexandria, often as a result of inter-marriage (Teit 1909: 760-3). Through these links and the close proximity of the Secwepemc and southern Carrier basket makers, it is not unreasonable to conclude that the flow of ideas in designs and technology may have moved among the three aboriginal cultures, perhaps with trade items over their traditional networks. Teit found, in particular, that there had been considerable trading between the Cañon [Creek] Secwepemc band and the Tsilhqot'in people, especially in salmon and its byproducts. Basketry was often included in these exchanges, he noted (1909: 535-6).

Neighbours of the southern Carrier people, the Secwepemc and Tsilhqot'in people, made birch bark baskets similar to those of the Carrier (Teit 1909: 477) (see Form B.2). Spruce root stitching on the ends of the basket was also similar but varying in design with single, double, or triple zig zag stitching on the ends (see Plate 13 (b), (c), (e)). However, the lower flap was fastened with separate vertical stitches only in the Carrier basketry. On the rim of the Secwepemc basketry, patterns were created with slightly separate stitches of varying lengths around the circumference. This was dissimilar to the Carrier method which usually had tight stitches in a stepped pattern discussed above. I also found that in the rims of Teit's examples (Plate 13 (b), (c)), as well as in contemporary Secwepemc birch bark basketry, they did not use thin spruce roots such as the Carrier basket makers used. Mary Thomas is holding a contemporary Secwepemc birch bark basket in Plate 14 and 15. Teit considered the triangular or stepped form of rim stitching to be the best design (see Plate 13 (a), (e)). 
Early decorative features of the Carrier basketry were also similar to those used by the Secwepemc basket makers such as the use of natural or dyed goose and swan quills, dyed horsehair, and the glossy bark of the cherry bark used in the beading technique (see Plate 13 (a)). Incised pictographic and geometric designs were similarly made in the Secwepemc basketry and on the walls of the Carrier baskets (see Plate 13 (a)) although I would suggest more so with the Carrier basketry. Mary Thomas noted that they occasionally may have put a leaf pattern on the walls of their baskets. Teit found that the construction of the Secwepemc basketry in his time was similar to their earlier basketry although he considered the ca. 1900 basketry to be lacking in workmanship.

Rim design is an important element in the analysis. The rim itself is usually constructed with a willow splint placed at the top and inside the mouth of the basket. The rim stitching on the Carrier basketry was consistently tight. Patterns in design were stitched in a series of stepped lengths of either ascending or descending stitches in a left or a right direction around the circumference of the rim (see Plate 13 (a) to (d). Informant Madeline Johnny's contemporary style of stitching was to separate the stitches on the rim as compared to the traditional tight stitching. ${ }^{27}$

More creatively, two types of decoration have been worked on the rim of some baskets. The first is beading, ${ }^{28}$ (see Fig. 1, and Plate 13 (a)). The technique involved a length of usually natural fiber woven along the flat surface of the rim in a horizontal direction under and over the spruce root stitched in a vertical direction under and over the splint and bark through holes previously punched with an awl. This process created a single beading pattern. When two fibers were used it created a double beading pattern. 
Three types of natural fibre that were used or occasionally used in combination, were natural or dyed horse hair, natural or dyed bird quills, or, a different type of bark (typically cherry bark).

The second type of rim decoration was created with sections of dyed spruce root. The dyed roots were stitched at the centre and the end in four locations with equivalent spaces between on the rim that ranged from two to four inches in width. The spruce roots were dyed red, orange, blue, green, or black using natural materials in pre-European time and commercial dyes that became available in post-European time. Teit (1909: 476-8) found that in traditional methods the materials used to dye the spruce root were, "berry juices and the fruit of the Strawberry Blite (Chenopodium capitatum)." Further, two common fibres used for dye were red alder-bark (Alnus rubra) that produced a reddish colour, and wolf-moss (Letharia vulpina) that produced a yellowish colour.

In describing elements of decoration and design used in rim ornamentation, Teit (1909: 476-8) noted the use of "dyed and undyed goose and swan quills split and scraped thin, dyed horsehair, and the glossy bark of the Bird-cherry (Prunus padus)." Harlan Smith also noted that "Cherry bark was used to decorate pails made of birch bark ... Quills of swan feathers ... and the cylindrical stem of dry grass called claka." 29 In 1920 and 1922, he explained that

"wild or bitter cherry (Prunus emarginata) was not found at Ulkatcho. It was fifteen miles away on the Salmon River and was plentiful at Long Lake, twenty miles from Ulkatcho. The cherries were eaten raw, and the outer bark used in the decorative "whipping" of the edges of birch bark pails." $" 30$ 
Ethnobotanist Nancy Turner (1996: 11) pointed out that cherry bark is found in moist thickets and edges of forests in British Columbia. Teit (1909: 478) found that the cherry bark was naturally dyed by "being buried in black sand." It was used in beading as rim decoration in what he called "checker-design" although it is no longer produced on contemporary birch bark basketry. Teit (1909: 476) found that the Nlaka'pamux people similarly used a wide variety of dyes in the ornamentation of their coiled basketry.

It is likely that the same fibrous plants used to dye the spruce roots for rim stitching in Carrier basketry was used in the Secwepemc and Nlaka'pamux basketry. I found that the baskets that had faded dyes on the rims were made from these natural dyes, while commercial dyes remained strong and vibrant. The widespread use of dyes may indicate a regional style, although it was not identified as a practice associated with a particular basket maker by my informants. Although, Madeline Johnny identified two of her baskets from my photographs (RBCM 4485 and 4486) based on dyed rim sections. She said,

"This is my work! I remember that. I used to make them for Christmas. That's why I put green on the rim. I made some really big [baskets], about twenty overall." ${ }^{31}$

Carrier women incorporated fabric as decoration on the rim of birch bark basketry. A form of rim decoration that indicates a regional style is found in baskets made by Carrier basket makers Agnes George of Nautley Reserve and Jennie Naziel of Moricetown respectively. These artists placed a piece of fabric, typically cherry bark or red wool on four sections of the rim over which they used an open cross stitching pattern in spruce root (see RBCM 14525 and RBCM 19282). In aboriginal enterprises discussed in Chapter 
Three, and as is evident here, Carrier women utilized new European materials. For example, they incorporated fabric as decoration on the rim of the birch bark baskets. Various geometric patterns incised on the walls of most of the Carrier basketry were the most consistently applied decoration. These consisted of single, double or triple incised line(s) with upright or inverted triangle motifs that formed a pattern, often in bands on the wall of the baskets. These were usually repeated down or across and sometimes diagonally across the design field or wall of the basket. Jenness (1943: 577-80) described the ceremonial regalia of "Round Lake Tommy, a Hagwilget Indian" (Tobey 1981: 422) (see Plate 18) that included a ribbon-appliquéd cloth dance apron. It was interesting to observe on the lower section of the apron, the horizontal lines of ribbon included a zig-zag design similar to the design elements found in various combinations on the Carrier basketry.

The second frequent incised design on the Carrier baskets consisted of plant motifs. They appear to be flowers, stems, leaves and stems. The leaves appear to be alder (Alnus glutinosa). This interpretation was suggested by Agnes George's daughter, Louise Joseph, of Hagwilget, originally from Nadleh Whuten in the central Carrier region. ${ }^{32}$ Louise explained that these were what her mother put on her basketry. Louise also provided the information to contact her sister, my second informant, Bernie McQuary.

There were only a few baskets with incised figural or animal representations among those analyzed. 
Sturdy baskets with plain walls completed the forms of Carrier birch bark baskets in the collection. While these baskets were more basic and/or undecorated, they were neatly constructed for the purpose they were intended.

Laforet (n.d.(a)) referred to innovations in forms of baskets in southern interior of British Columbia Nlaka'pamux and St'atl'imc coiled basketry similar to European containers. Examples were candy dishes, tea sets and comb holders. I did not find similar examples in the Carrier collection studied. Two innovative forms in the Carrier baskets, RBCM 14525 and 18242 could have been intended to hold a potted plant or as a paper waste container. Another was RBCM 10530c, the larger of a three part nesting series of baskets perhaps used to hold small objects. CMC VI B 71 is unusual in the group of Carrier baskets studied. As suggested, it is more typical of a coastal British Columbia style.

When stitching the upper end section, the Carrier basket maker often created a decorative effect (see Plate 13 (b), (c)). The stitching on the bottom seams generally reflected the same accuracy and quality as the stitching on the upper end section. This work, which can be seen as a design element, is the individual basket maker's signature and reflects her style and quality of workmanship. Basket makers Madeline Johnny and Bernie McQuary ${ }^{33}$ explained that the end stitching defines the signature of the basket maker. In a subsequent interview, Bernie confirmed photographs of Madeline's baskets by studying this feature. 


\section{ALGONQUIN/MONTAGNAIS BASKETS}

The primary collectors of the Algonquin/Montagnais baskets were Edward Sapir and Frank G. Speck. Baskets and their makers identified were Algonquin of Kitigan Zibi, Catherine Michel (CMC III L 28-30, 32-3, 35, 37-8, 40-3, 47, 49, 52-2, 55-7, 59) and E. Michel (CMC III L 31, 34). I had only a few Montagnais baskets to work with because the majority (22) of their baskets collected by Speck and Sapir from Mashteulatsh (PointeBlue at Lac St. Jean, Quebec) were unavailable for study. They had been returned to the community on a long-term loan, although the CMC catalogue cards were available for reference. A complete list of the baskets studied is provided in the Master Table (Appendix Four).

TABLE 2: Main Forms and Variations of Algonquin/Montagnais Basketry

\begin{tabular}{|c|c|c|c|}
\hline Form C & $\begin{array}{c}\text { Form C.1 } \\
\text { Tall, Square Base }\end{array}$ & $\begin{array}{c}\text { Form C.2 } \\
\text { Shallow, Square Base }\end{array}$ & Total \\
\hline & 13 & 5 & 18 \\
\hline Form D & $\begin{array}{c}\text { Fall, Rectangular Base } \\
\text { Form } E\end{array}$ & $\begin{array}{c}\text { Form D.2/3 } \\
\text { Seamless }\end{array}$ & Total \\
\hline & $\begin{array}{c}\text { Form E.1 } \\
\text { Round Base }\end{array}$ & 4 & 38 \\
\hline & 5 & & Total \\
\hline
\end{tabular}

There were 63 baskets in the Montagnais/Algonquin group, primarily in two forms, Form C and Form D (see Appendix One, Table 9) Eighty percent were tall baskets that 
may include a lid in Form $C$, while twenty percent were shallow open trays in Form D. Two were innovative forms that fit into neither category. All of these forms were made with similar materials in construction and decoration. Included were birch bark, maple wood splint, spruce root, sinew and European textiles such as string and thread. The only method of decoration was incising.

\section{$\underline{\text { FORM C.1 }}$}

Speck noted (ca.1941: 236) that baskets in Form C.I (Fig. 11) were a "vessel" used to carry water or maple sap by the Algonquin and Montagnais people. The base was square and the sides were high. Form C.I usually had a handle that often was made of basswood, although in this case sinew

(Fig. 11) that was constructed into the rim. This form did not have a lid. (See Plate (13) (a)) for pattern.) The

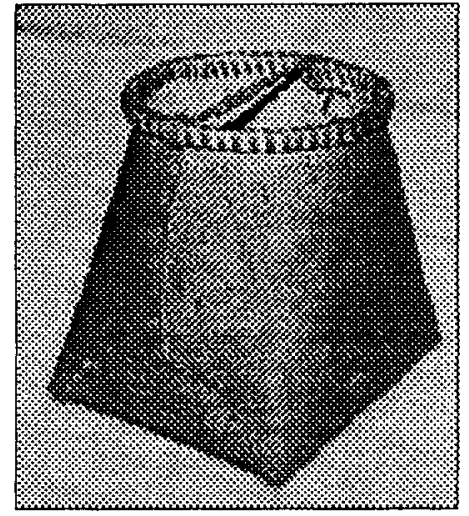

FIG. 11. Algonquin/ Montagnais. Form C.1. CMC III L 57. Maniwaki. E. Sapir. 1912. L.. $16 \mathrm{~cm}, \mathrm{~W} .14 \mathrm{~cm}, \mathrm{H} .17 \mathrm{~cm}$ method of end stitching was in pairs, or were one-inch apart in a horizontal direction over the seam. In some instances, sinew was used for stitching. Speck also noted (ca.1941: 237) that the seams of Form C.I were coated with spruce gum pitch in order to make the container watertight and that this form was being replaced by metal pails. A hoop of maple wood (236) was attached on the outside of the usually round mouth with stitches that were of the same length, or if stitched from the inside, only the third stitch was inserted through the bark. They were all the same length. Incised decoration appeared on the design field as floral motifs. 


\section{FORM C. 2}

Speck (ca.1941:239) described Form C.2 (Fig.

12) as a "birch bark dish." The base was square with

sides that flared from four straight corner seams to a wide

mouth. Speck (109) noted that this form was used as an

eating dish or bowl by hunters in the remote regions of

Quebec. It was a sturdy basket and was frequently

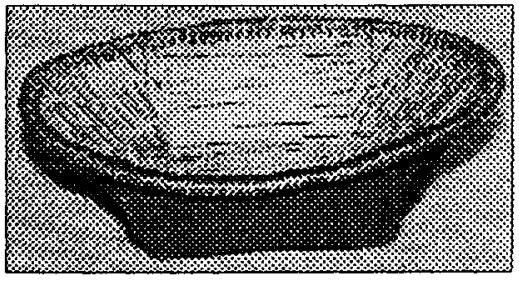

FIG. 12. Algonquin/ Montagnais. Form C.2.

CMC III L 28-30. Maniwaki.

E. Sapir. 1912.

L. $38 \mathrm{~cm}, W .32 \mathrm{~cm}, H .13 \mathrm{~cm}$.

undecorated.

\section{FORM D.1}

Form D. 1 (Fig. 13) was described as a "birch bark receptacle" by Speck (ca.1941: 236) that varied in size from 6 to 24 inches long. Although the pattern (see Plate 13 (a)) was the same as for Form C.I, the walls were generally lower in height than their length and they tapered in towards the mouth. Speck (236) noted that a hoop made of maple wood was placed on the outside of the rim before stitching

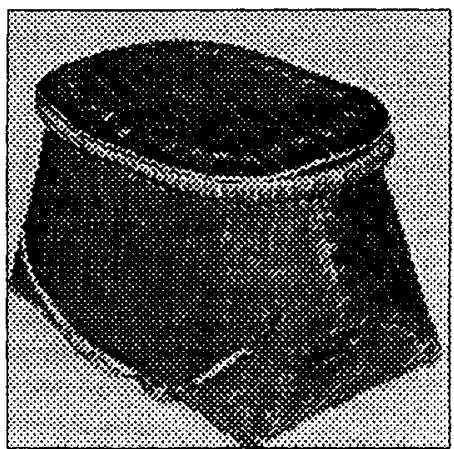

FIG. 13. Algonquin/ Montagnais. Form D.1. CMC III L 38. Maniwaki. E. Sapir.1912.

L. $24 \mathrm{~cm}, W .14 \mathrm{~cm}, H .15 \mathrm{~cm}$.

with spruce or basswood roots. This form often had a fitted lid with a skin thong attached. Form D.l was a multi purpose basket used for storage of materials and food by both Algonquin women and men. This type of basket was indispensable to the Algonquin people living in the forests, whereas those living near urban 
centres had replaced baskets with metal cans and cardboard boxes. While all of Speck's examples now in other museums had incised elements on the walls, most in this study did not. The method of end stitching varied from vertical or horizontal short separate stitches, to vertical ones that were one or two-inches apart on the seam and continued along the curved bottom seam.

If the basket had a lid, as most Algonquin/Montagnais did in this study, it was constructed in two layers of birch bark. Vertical stitches, two inches apart and indented one-inch, followed the shape of the basket as it fastened the collar/band intended to fit inside the basket. The edge of the lid was overcast with short stitches, one-half inch apart, and long vertical stitches across the middle of the lid.

The rim stitches were the same length over the outer wood hoop. There was a variation in rim stitching in this form. It was predominately the same length, or the rim was not finished, or stitching was through roughly 'punched' holes, two inches apart. One basket had two long rods fastened on each side and tied at five locations with string.

\section{FORM D.2}

Speck (ca.1941:237-8) described Form D.2 (Fig. 14) as a "folded double" vessel, in a seamless "trough-like" construction (see pattern in Plate 13 (c)). The ends were simply folded up and fastened with minimal spruce or basswood root stitching. It was originally used as a

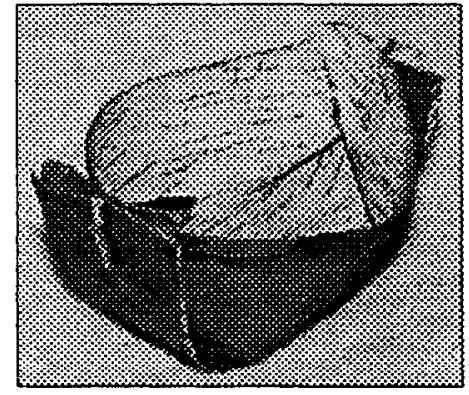

FIG. 14. Algonquin/ Montagnais. Form D.2 CMC III L 11 and CMC III. L 12. Maniwaki. E. Sapir. 1912, L. $24 \mathrm{~cm}, W .18 \mathrm{~cm}$, H. $12 \mathrm{~cm}$

watertight seamless cooking container in the northern region, 
as when it was wet, the basket resisted heat. It later became used as a sap trough or used for other liquids (238).

\section{FORM D.3}

Speck (ca.1941: 238-9) described Form D.3 (Fig. 15)

as a "pail." This basket was a variation of the seamless

vessel in Form D.2. The ends were folded outside of the form, bent together and caught with a fastening of spruce root or basswood fibre. Form $D .3$ was also used as a container for collecting sap. It did not have a splint fastened

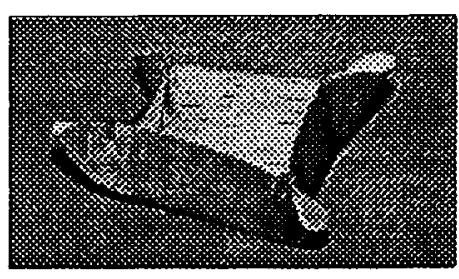

FIG. 15. Algonquin/ Montagnais. Form D.3. CMC III L 117. Lake Temiscaming, and CMC III C 449. Lac St. Jean. F.G. Speck. 1913. L.. $15 \mathrm{~cm}, W .13 \mathrm{~cm}, H .5 \mathrm{~cm}$ at the mouth and was infrequently decorated with incised elements.

\section{FORM E.1}

The method of end stitching in Form E.l (Fig. 16) varied from either small horizontal stitches over a single seam, vertical stitches from within the previous stitch, or small separate vertical stitches along a single seam. Separate stitches on the lid were interconnected across the middle, as well as in circular stitching attaching the vertical strip of bark cuff intended to fit inside the basket. The method of stitching on the rim was overcast spruce root stitches of the same length, and/or overcast one-inch into the

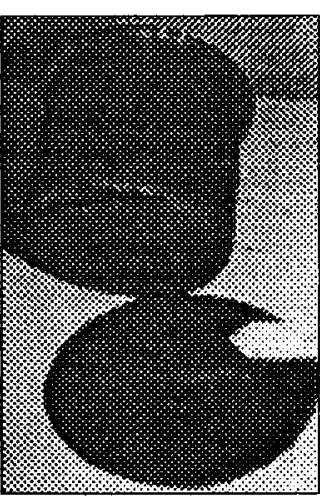

FIG. 16. Algonquin/ Montagnais. Form E.1. CMC III C 17. Pointe Bleue. E. Sapir. 1911.n/a

reinforcing bark strip. The circular bottom was attached by small vertical separate stitches 
across the seam. This form did not have decorative rim stitching. The design field or wall had incised plant motifs or horizontal and vertical lines.

\section{Algonquin Basketry Innovations}

INNOVATION 1 This Algonquin basket (Fig. 17) had a square base, four compartmentalized sections and an irregular mouth. The materials used in the construction were birch bark, spruce root and hide. The only stitching was at the top edge of the basket that fastened four sections together creating a quatrefoil shape.

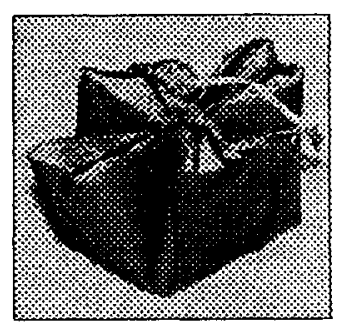

FIG. 17. Algonquin Innovation 1. CMC III L 59. Maniwaki. E. Sapir. 1912. L. $16 \mathrm{~cm}, W .12 \mathrm{~cm}$ $\mathrm{H} .10 \mathrm{~cm}$.

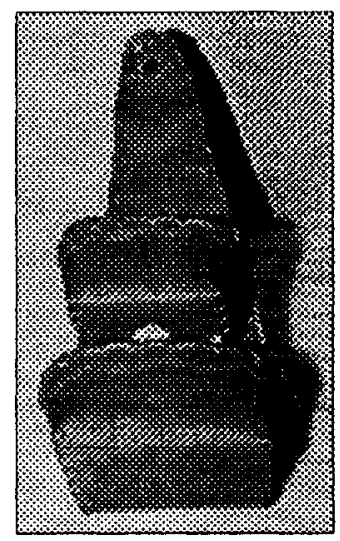

FIG. 18. Algonquin. Innovation 2. CMC III L 33. Maniwaki. E. Sapir. 1912. L. $18 \mathrm{~cm}, W .11 .8 \mathrm{~cm}$, $\mathrm{H} .34 \mathrm{~cm}$

\section{Discussion of Algonquin/Montagnais Stylistic Analysis}

Speck (ca.1941: 242-3) wrote that the 'rim wrapping' was "close and undecorated, 
Chapter Four / 90

the spruce roots being left in their natural colour." There were no quill or dyed roots used on the rim of the Algonquin and Montagnais basketry. A common feature in this basketry was the "fitted lid." It had a cuff attached to the underside of the lid stitched with spruce roots to fit inside the mouth of the basket.

A wooden hoop was placed on the outer side of the basket in the Algonquin/ Montagnais basketry. Speck attributed this form of construction to post-European influences as in "European boxes." Examples include CMC III L 24, 34-44, 46 -52, 54-5, $103,105-6,112-3$

An apparently recent type of construction by Rivère Désert basket makers that Speck observed (1937: 243) was the tall rectangular basket sewn at the four corners (see CMC III L 19). Yet, this style still had fitted lids and the common form of decoration. Montagnais basket makers made a cylindrical form with lids and separate bottoms. As in the construction of the Algonquin lids, the inside band was stitched under the lid in four or five places with a single spruce root stitch.

\section{Decorative Methods in Algonquin/Montagnais Basketry}

Algonquin basket makers incised designs of representational plant (floral), animal or human figures, and circles or geometric design elements on their basketry. The design elements were made with stencils in cut-out shapes that appeared as solid images on the birch-bark. The stencil technique was created by scraping the surface of the birch-bark "around" the stencil (Naylor, 1975) rather than inside a traced outline of the stencil.

Speck (ca.1941: 243) explained that these decorative techniques were made with "patterns 
on the dark surface of spring-peeled bark by moistening and then scratching away the softened layer surrounding the pattern." He noted that a Rivière Désert basket maker relied heavily on her "cut-out birch bark," "mažne 'žga," or "picture cut" pattern "for the transfer of pattern." Speck (ca.1941: 246) defined the process according to European art conventions

"Negative Process: a cut-out stencil is placed upon the dark surface of the birch-bark and the area around the pattern is scraped away until the lighter undersurface is exposed, thereby denoting the term scraped or sgraffito which occurred in the European ornamental technique, on a coating of plastic at Bologna until the $17^{\text {th }}$ Century." The Algonquin basket makers followed this method.

"Positive Process: [followed by Carrier basket makers where the] "design is scratched into the dark coring of the bark." Other terms attributed to the positive technique are inscribed, or incised, or scratched."

Speck (ca.1941: 247) noted that the Lake Temiscaming Algonquin basketry (see CMC III L 100 and 108) was similar to the basketry tradition of the Ojibwa people who included design elements of animal and human outlines in their basketry. The eastern Algonquin and Montagnais basketry did not include these type of design elements. Speck found that the Rivière Désert basket makers increasingly preferred to make floral design elements.

A striking feature of the Algonquin birch bark decoration to which Speck (ca.1941: 245) referred was a "canoe wrapping" technique. The space below the rim of the basket was decorated with a series of design elements in either a "positive" or a "negative" technique. Following reinforcement of the mouth of the basket with a willow splint and spruce root stitching, a pattern was scraped in the normal "form of a cut-out decoration" 
on a solid band around the circumference of the basket, approximately one inch below the rim. The end result was a visual image that appeared to support the upper wall and at the same time artistically decorate it (see CMC III L 20, 102, 103, 105).

A prominent style of end stitching found on the Algonquin and Montagnais basketry was the "tack stitch" method of the Rivière Désert and Montagnais basketry. The stitch entered the bark in an upward angle and then down within less than $1 / 4$ " to the inside of the surface, then from one to two inches before it came through to the outside (Speck ca.1941: 242).

As noted earlier, the Algonquin stencil tradition appears to have evolved from early European designs taught by the Roman Catholic nuns beginning with Marie de l'Incarnation (Mahoney 1989) (see Plates 9 to 11). Floral elements sewn by the nuns on liturgical vestments and altar cloths may have been a forerunner of the stylized stencil floral elements found on the Algonquin basketry. In 1999, I observed these floral cut out patterns in display cases at the Quebec City Ursuline Museum. Algonquin birch bark basketry with stenciled floral elements on the design fields were included.

The early method of creating patterns without the benefit of European tools such as scissors or knives preceded the teachings of the nuns, according to Speck. He (ca. 1941: 250-1; 1937: 74-80) considered that the traditional, bitten birch bark work applied to the Algonquin and Montagnais basketry may have been a forerunner of the cutout patterns utilized by both groups. Bitten patterns were created on a thin single piece or membrane of inner birch bark folded once or twice. The designs were, in effect, created "blind" with precision developed through experience. The bark was usually bitten into 
with the incisor teeth that left impressions but did not perforate it. Ovals, curves and lines appeared when the piece of bark is opened. They were then cut with scissors and placed as patterns on surfaces, usually for embroidery and only occasionally in birch bark decoration. Speck further noted that the bitten method was very characteristic of the Montagnais basket makers. These were the first aboriginal women with whom the nuns worked. The bitten method was also used by Algonquin women though to a lesser extent. The method was in use when Speck visited the Rivière Désert basket maker, Mrs. Pierre Clement. She was highly respected and was still practicing the method, while Mrs. Buckshot in the same community produced her designs using scissors. Aboriginal basket makers that were closer to logging communities typically used paper for their patterns. Speck (ca.1941:260) found that the majority of the Algonquin Rivière Désert baskets were decorated. He attributed this to the adaptation of a more settled life since ca. 1870 as the aboriginal people moved from seasonal hunting and trapping to farming following the practices of the settler society in their region.

In his monograph on Algonquin birch bark basketry (ca. 1941: 235-6), Speck found that the basket makers produced basketry for trade, first within their own communities. Second, they traded outside of their own networks with European people for a profit, either in goods or money. Speck suggested that this was a traditional practice of the Algonquin people. He also found that quality and artistic workmanship were admired by members of the aboriginal community, noting private collections in addition to the basketry that was in daily use. 
Chapter Four / 94

Speck believed (ca.1941: 235) that selling to the outside community influenced the development of the art form and increased demand. He believed that the application of unusual cut-out pattern figures was motivated by commercial sales, in that the production capacity for European settlers and traders visibly changed their art form to a stylized European version of their former designs. Yet, Speck denied that European influences had created an impulse to decorate, or to create fancy articles. Instead, he believed that the motivation to improve on the quality of their material culture came from their own cultural traditions that were being grafted onto the encroaching European influence beginning ca. 1870 and expanding with new forms or features.

Some baskets that Speck saw were known to have been three generations old, made by the owners' great-grandmothers. These baskets and others were made in the traditional way. Mrs. Buckshot, for example, then in her seventies, had learned her art from her mother and had not made any changes in construction or patterns of decoration. However, two other Rivière Désert women had earlier lived about one hundred and fifty miles away in settlements on the St. Lawrence River prior to 1854 . Thus, the possibility of European influence on aesthetic developments in Algonquin and Montagnais basketry cannot not be ruled out. The difficulty is to ascertain on what style or form, decoration or design the influence had been made.

Subsequently, Speck found that the emerging interest in their material culture had motivated basket makers to reproduce innovative ideas taken from the European culture. For example, in 1937 , birch bark baskets had been created in the shape of a coronation 
crown, a ribbon bow and a goblet (ca.1941: 236). Moreover, Madame Cesar combined cut-out and sewn patterns with spruce root rim loop fancy work (249).

\section{Identity and Regional Style}

In considering subarctic birch bark basketry, what is the relationship between regional style and basket makers' identity? Mary Aski-Piyesiwiskwew Longman, member of the Saulteaux Gordon First Nation, and First Nations Education Coordinator at the University of Victoria explained that "identity is complex and shaped by external and internal factors. It is diverse and perpetually evolving. It never becomes fixed."34 Longman illustrated her comment with the renowned product of the Coast Salish women, the Cowichan sweaters. There are distinctions in the Cowichan sweaters that are based on styles, colours and patterns that are maintained. Yet styles evolve among knitters. Similarly, Nuu-Chah-Nulth basket makers Pauline Joe and Kathy Edgar (discussed in the next Chapter) explained that their families' designs were passed down through the generations and incorporated in their own basketry.

In the past, aboriginal basket makers in other parts of British Columbia were influenced by issues of "origin, trade, intermarriage and communication which transcended local differences and perceptions of identity" (Laforet, 1990: 286). Determining regional styles is complex.

Madeline Johnny and Bernie McQuary stated independently that the incised designs on Carrier basketry were not necessarily representative of a particular region. They were more likely to be an expression of personal style. They pointed out that their incised 
designs were always in the family, but had no specific meaning. Madeline's grandmother put designs on the baskets she used for collecting berries. Colours and patterns which may have been used on "fancy baskets" were simply the choice of the basket maker. When Bernie saw Madeline's basket, she said that Madeline decorated her basket because she wanted it to be "fancy, just for herself." In earlier times, if she were selling her basketry to European settlers, she would put designs on her baskets. Today, Madeline explained, she does not incorporate designs because current buyers "do not want them." Madeline incorporated green and red dyed spruce root sections around the circumference of two baskets, RBCM 4485 and 4486 (Fig. 19 below) that were meant to hold Christmas candies.

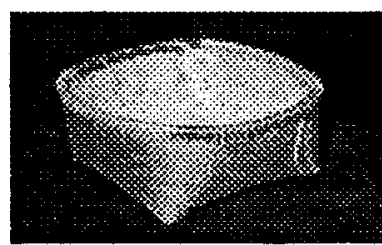

RBCM 4485

Carrier, Stony Creek Vanderhoof Mrs. Washington 1931

L. $20 \mathrm{~cm}$, W. $18 \mathrm{~cm}$, H. $9 \mathrm{~cm}$.

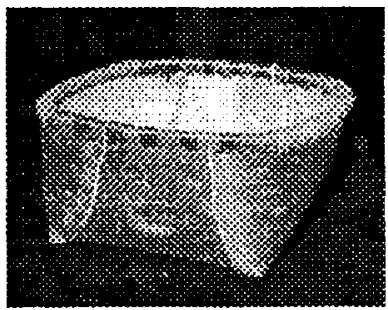

RBCM 4486

Carrier, Stoney Creek Vanderhoof Mrs. Washington Before 1931 L. $19 \mathrm{~cm}, W .18 \mathrm{~cm}$, $\mathrm{H} .9 \mathrm{~cm}$.

FIG. 19. Personal choice of decoration by basket maker.

A salient feature of Carrier basketry is the personal signature or style of the basket maker found in the stitching design on the end of the basket. Madeline and Bernie each pointed out that the signature was unique and thus identified the maker. In examining 
photographs of baskets I provided, Bernie and Madeline identified certain baskets according to their maker by studying the end stitching. Examining Madeline's baskets during our interview also confirmed her own signature in end stitching was of separated double stitches. Further examples of Madeline's baskets were not found in the collection studied using this criterion.

Bernie identified several baskets, now in the RBCM, that were made by her mother, Agnes George, approximately fifty years ago. Bernie identified her mother's personal style in stitching on the lower end by the very tight and small stitches, explaining again that this "signature" is what one looks at to determine the maker of the basket. I also noted Agnes' signature on her baskets that Bernie had in her home for comparison with those in the study. While the signature on the lower end of the baskets, RBCM 7070 and 8738 (Fig. 20) by Agnes George was unique to her, an incised floral design element was also found on the Carrier baskets made by her in RBCM 7070, 8738, 14525 and 19282 (Fig. 20) that helped in their attribution.

A salient feature in regional identity was the rim design shown in the photograph of Moricetown resident Jennie Naziel in Uli Steltzer's (1976: 132) photographic essay, and a photograph of Agnes George (133), and, in baskets RBCM 14525, 19282, and CMC VI B 140 (see Fig. 20) collected at Stuart Lake. During my visit to the K'San Historical Village, I found the same rim design on recent baskets made by Noleen McQuary, Agnes George's granddaughter. As well, the same rim design appears on the basket RBCM 14525 (Fig. 20) purchased at K'San Historical Village in 1974. 


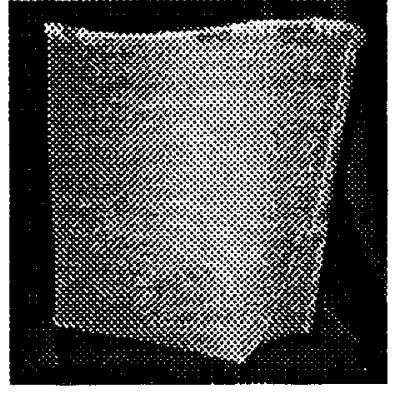

RBCM 7070, view 1 Carrier. Fort Fraser Purchase by Museum from Mr. Maxim George. 1951 L. $38 \mathrm{~cm}, W .38 \mathrm{~cm}$, $\mathrm{H} .38 \mathrm{~cm}$.

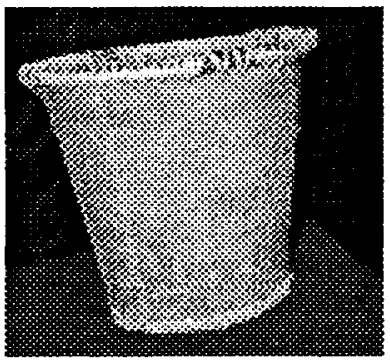

RBCM 14525, view I Carrier, Fort Fraser. P.L. MacNair purchase for Museum at K'San Sales, Hazelton. 1974 H. $20 \mathrm{~cm}$, Dia. $21 \mathrm{~cm}$.

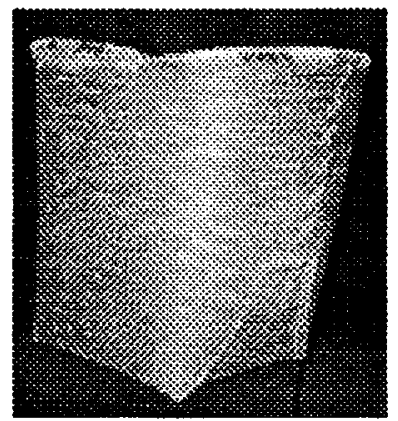

RBCM 7070, view 2

Carrier. Fort Fraser

Purchase by Museum

from $\mathrm{Mr}$. Maxim

George. 1951

L. $38 \mathrm{~cm}, W .38 \mathrm{~cm}$, $H .38 \mathrm{~cm}$.

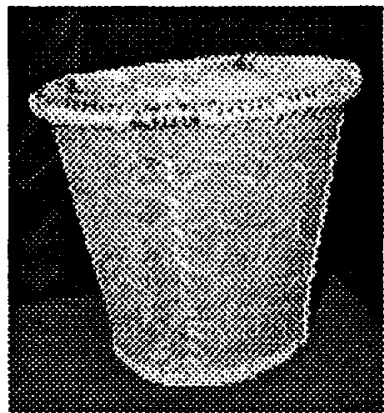

RBCM 14525, view 2

Carrier. Fort Fraser.

P.L. MacNair purchase for Museum at K'San

Sales, Hazelton. 1974 H. $20 \mathrm{~cm}$, Dia. $2 \mathrm{lcm}$.

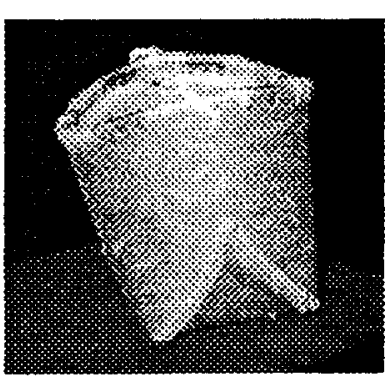

RBCM 8738. Carrier. Nautley Reserve/ Fort Fraser. Purchase by Museum from $\mathrm{Mr}$. Maxim George. 1957 L. $23 \mathrm{~cm}, W .39 \mathrm{~cm}$, $\mathrm{H} .14 \mathrm{~cm}$.

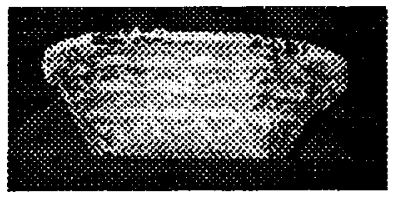

RBCM 19282. Carrier.

Mr. W.B. Russell

Coll'n. 1991

L. $28 \mathrm{~cm}, W .16 \mathrm{~cm}$, $\mathrm{H} .10 \mathrm{~cm}$.

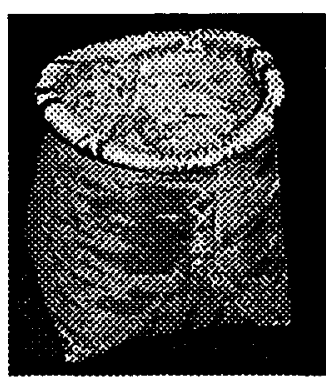

CMC VI B 140.

Carrier. Stuart Lake Rev. A.G. Morice. 1892

L. $12.5 \mathrm{~cm}$,

W. $11.5 \mathrm{~cm}$, $\mathrm{H} .15 \mathrm{~cm}$.

FIG. 20. Personal style of Agnes George, and regional identity of salient rim feature. 
These incidents confirm that this style of rim design originated from a central Carrier community, likely Nautley Reserve. In comparing the unique style of rim designs found on these baskets, it should be noted that Moricetown is a considerable distance from Nautley reserve and is close to Fort Fraser. Similarly, Stuart Lake is within this same region as is Moricetown and Nautley Reserve. With a reasonable degree of certainty, a 525 (Fig. 20) purchased at K'San Historical Village in 1974. particular style may also be demonstrated in the several Algonquin baskets made by Mrs. Catherine and E. Michele of Kitigan Zibi that were collected by E. Sapir in 1912, (CMC VI L 28-35, 37-8, 40-3, 47, $59,51-2,55-9)$.

As these baskets identified their maker and are high in number, identical in form, rim and end stitching, lid construction and stitching, they are characteristic of these basket makers. Because the remaining baskets in the series, that is, CMC VI L 36, 39, 44, 46, 48 and 50 are the same in style and construction, the fact that they were not identified as made by either Mrs. Catherine or E. Michele may have been an oversight in cataloging.

\section{COMPARISON OF CARRIER AND ALGONQUIN/MONTAGNAIS BASKETRY}

A formal stylistic analysis of the Carrier and Algonquin/Montagnais people's birch bark basketry has revealed salient differences in form, construction techniques, decorative materials and/or design elements.

The Carrier basketry had two main forms. Form $A$ was a tall basket with an open rim or mouth, and Form $B$ was a shallow open tray. The Algonquin and Montagnais baskets were also constructed in two main forms but these were quite different from the 
base that may include a lid. Form $D$ included tall and shallow baskets constructed from a rectangular base. Form $E$ was a minor form constructed with a round base and lid.

A notable style of end stitching found only in the Algonquin and Montagnais basketry was described as the "tack stitch" method. Conversely, the end stitching on the Carrier baskets was consistently tight and precise stitches that often formed a decorative pattern..

The Algonquin and Montagnais baskets had a rim splint or hoop incorporated into the rim on the outside of the basket, whereas the Carrier baskets had the splint incorporated on the inside of the basket and fastened by the rim stitching.

The Algonquin and Montagnais rim stitching typically had close but separate stitches. The spruce or basswood roots were left in their natural colour and lacked a decorative style. Tight rim stitching that usually incorporated a pattern design was characteristic of the Carrier basketry. There were no natural or dyed bird quills or other materials applied to the rim of the Algonquin and Montagnais basketry. Natural and dyed bird quills, or horse hair, and dyed spruce roots incorporated on the rim in alternate patterns only occurred on the Carrier basketry. The Algonquin basketry had a false decorative band incised below the rim, or sometimes an actual band of birch bark with a plain or scalloped bottom was incorporated within the rim stitching.

In the Montagnais group of baskets. I found an unusual technique. Geometric design elements were created with a positive technique situated within a negative technique. These looked like hollow outlines (see CMC III C 163, 445, 448). The 
Montagnais basket, CMC III C 433, had images that were created through the negative process.

In many cases the Algonquin stencil designs had been incised on the bark at the pattern stage before construction. This was not observed in the Carrier basketry.

The Algonquin and Montagnais basket makers made (a) patterns on the dark surface of spring-peeled bark, Speck explained (ca. 1941: 243), (b) while the practice in the subarctic region of British Columbia was to gather summer bark after the sap had stopped running, according to informants Madeline Johnny and Bernie McQuary. However, Mrs. Buckshot, who was the oldest Algonquin basket maker with whom Speck consulted, utilized both methods demonstrating versatility and creativity. This confirmed that there were two approaches to gathering the bark by Algonquin basket makers. Since Mrs. Buckshot was a child, she had stitched the stenciled pattern on the uncoated summer-bark, and in other cases scraped the pattern away on the moist spring-bark (248).

The most consistent designs incised on the Carrier basketry in the positive technique were geometric designs and patterns. In only one instance did an incised human outline appear on a Carrier basket, CMC VI B 447, collected in 1930.

In four instances, animal forms were created on Lake Temiscaming Algonquin baskets, CMC III L 100, 102-3, 108, that Speck attributed to the Ojibway tradition. The eastern Algonquin and Montagnais basket makers did not include human or animal design elements on their basketry. Speck found (ca.1941: 247, n. 15) that the Rivière Désert basket makers increasingly preferred to make floral design elements on their baskets. 
Chapter Four / 102

There was a noticeable difference in the uses of basketry between the Carrier, and the Montagnais/Algonquin people according to ethnographic data. These differences may reflect the geographic regions the two groups lived in. The use that the Algonquin and Montagnais had for their open form of basketry was centered around maple sap gathering and the production of maple syrup, while the basketry with lids were used as a substantial container for storing food or clothing. In fact, one was lined with cotton fabric.

As the Carrier baskets did not have lids, they appear to have been used mainly for cooking and gathering berries, confirmed by ethnographic information from Carrier basket maker Madeline Johnny. She explained that branches of the local fireweed plant were placed on top of the goods inside the basket instead of a lid.

There were similarities in one form of the Carrier and the Algonquin baskets. These were baskets with a square base that formed a shallow tray (CMC VI B 107, 113, 115, 116, 131 and CMC III L 28, 29, 30).

A salient personal feature of Carrier basketry was the artistic signature created by the design of the end stitching. The features in the five baskets by Adele were identical and not found in other unattributed Carrier basketry in the collection. Thus, not only is the end stitching identifiable with a particular basket maker, the incised designs and rim design may also be unique to a particular basket maker as she brings change to the art form through her designs.

Certain Carrier and Algonquin baskets demonstrated innovation and change to the basketry art form. These baskets almost certainly may be the result of the arrival of the settler population to their regions. 
Another salient feature of regional identity was also found in the characteristic rim design in central Carrier basketry. The correlation discussed earlier suggests that the design of open crossed spruce root stitching over a strip of fabric or bark on the mouth of the basket is a regional style that is characteristic of the central Carrier communities of Nautley Reserve, and, Fort Fraser on Stuart Lake.

A distinguishing feature of Algonquin basketry, as opposed to Carrier basketry, is found in the design elements on the walls of the Algonquin basketry that is specific to the Algonquin/Montagnais basket makers. The floral design elements on the Algonquin basketry were created by the negative process technique where the surface of the birch bark was scraped around the design element. The reverse is the case with the Carrier basketry that had freehand floral and geometric elements created through the positive process that did not use patterns.

In the next Chapter, the voices of these subarctic and other aboriginal basket makers emerge. Their personal stories help to situate the subarctic basketry collected in the early twentieth century within its historical framework. 


\section{Chapter Five}

\section{EMERGING VOICES OF BASKET MAKERS}

This Chapter considers the stories of the few remaining traditional basket makers and how they reflect on their traditions and the meaning of subarctic birch bark basketry. With one exception, details and stories of the many unidentified basket makers represented in the analysis were not recorded. Contemporary basket makers expand on topics such as family-based learning and provide personal reflections that offer insight into the work of early subarctic basket makers

I had the opportunity to interview a few remaining traditional basket makers, perhaps the last of many generations of these artists. These women were mostly of advanced age and, in fact, one became too ill to interview as I was making arrangements.

I arranged to have interviews with two central Carrier members on July 29 and 30 , 2000. The first was on July 29, 2000 with Madeline Johnny, elder, basket maker and teacher. Madeline lives on the Stony Creek Reserve in the northern interior of British Columbia. Not far from her home, I interviewed Bernie McQuary at her home on July 30, 2000. Comments were elicited from both elderly basket makers while studying my photographs of the collection. It turned out that the collection included Madeline's own basketry, as well as that of Agnes George, Bernie McQuary's mother.

I was also very fortunate a year later to have an interview with Mary Thomas ${ }^{35}$ (1917-) (see Plates 14 and 15). I had a similar conversation with acclaimed basket maker in both Coast Salish and Tsimshian weaving with Rena Bolton ${ }^{36}$ whose ancestry is of the 
As I endeavoured to follow Boas' methodology (Schevill 1992: 168-9) through conversations with basket makers that pertained to their basketry, stories emerged. They are included in this analysis with the makers permission.

From the photographs, they were able to identify and discuss features of certain basketry. Traditional knowledge was included in their comments. As a result, I was able to understand why there were differences between old and contemporary basketry, including the signatures that identified basket makers. This became a record of their traditional knowledge that has not been recorded elsewhere.

The non-Carrier basket makers were interviewed to obtain their perspective on basket making in contemporary times. As a result, I was able to get insight into the relations between Secwepemc and Carrier basketry. In addition, some general concerns of the basket makers are recorded.

\section{Overview}

We do not know the personal stories of the makers of the baskets studied because, with only three exceptions found in my research, anthropologists and ethnographic collectors generally did not provide that type of information. Barbeau and Smith made observations about the locations where they acquired Carrier basketry and in one instance the middlemen who sold the basketry. Perhaps because collecting basketry was not their primary task, they recorded very few details about what they collected. Although Barbeau did not interview the basket makers in the Hazelton area, he knew of Boas' suggested approach (Schevill 1992: 168-9) to collecting material culture that emphasized interviews 
with basket makers. Conversely, Sapir at least noted that the maker of twenty-two of the thirty-four birch bark baskets he collected in (ca.1912-13) was Algonquin basket maker Catherine Michel. Frank Speck (ca.1941) mentioned the names of two other makers of baskets but not of those in the CMC.

The personal approach to learning about basketry had its inspiration in my earlier study of a basket maker in another region of North America (Thornburn, 1999). A brief reflection of her story is therefore relevant to this analysis as it sets the tone for my enquiry,

"Mohawk basket maker Mary Adams (1917-1999) began making splint ash and sweet grass baskets to support herself when she was orphaned at age ten. Mary continued to make these baskets to contribute to the family income after her marriage. As Mary's expertise in basketry developed, she gave back to her family and community by teaching the Mohawk tradition of fancy basketry. The quality and design of her baskets subsequently led Mary to travel outside her home to give demonstrations of her artistry. The culmination of her lifework can be seen in the Pope Basket, now in the collection of the Vatican Museum. Other highly sculpted basketry art-forms are now in the collections of the United States Smithsonian Institution's Renwick Gallery and the National Museum of American History." (Thornburn 1999, 2001).

Mary Adams' life experience in subsisting on the production of her basketry has been repeated by other aboriginal basket makers discussed in this Chapter after European explorers and traders travelled through and settled on their lands.

\section{The Importance and Meaning of Basketry}

Cultural anthropology originally tended to see aboriginal material culture in a utilitarian way as objects (Berlo: 1992: 1-2). Yet, basketry has additional meaning to aboriginal people and those non-aboriginal people who appreciate it. It has a spiritual and 
cultural dimension beyond the physical commodity. On more than one occasion, when I have spoken with basket makers and other aboriginal people, their emotions about basketry became very evident.

"Alive and in motion" were expressions used by Mary Adams (Thornburn, 1999). Ojibway artist Helen Wassegijig, a visual artist in basketry using mixed media, referred to baskets as sacred in the sense that they hold special things. ${ }^{37}$ Conversations with staff in art galleries and cultural centres in the aboriginal community, aboriginal graduate students and aboriginal university professors in personal conversations about my work with First Nations men and women including basket makers, all revealed a sensitivity when holding, viewing or discussing basketry. Basketry is respected and revered by aboriginal people.

Non-aboriginal people cannot immediately imagine or experience the feelings that aboriginal basket makers have about their work. Basketry links aboriginal people to their traditional knowledge, culture and spirituality. Cowichan basket maker Stella Johnny quoted her mother by saying, "when you are weaving your basket, you are putting things right within yourself." 38 Stella also told me that her basketry had helped her through many personal difficulties and challenges in her life when I spoke with her at a basket weaving conference that she organized in Duncan, British Columbia. She had been motivated to share the meaningful tradition of her basketry with her own community and with others.

Basketry reflects relationships within aboriginal peoples ancestry, ecology and spirituality. For example, several aboriginal women and basket makers have told me that a basket maker will place food or tobacco at the base of a tree as she prepares to remove it's bark or roots in an act of respect. The tree will give up its roots or bark to the basket 
maker when she prays for permission to take it. Only one root or one piece of bark is usually taken from a tree at least for many years by which time the surface scar has healed over. This was explained to me by Mary Thomas. ${ }^{39}$

These thoughts suggest that to the basket makers, their products are part of themselves and thus of their ancestral heritage. It is only natural to conclude that they put themselves, including their own creativity and personalities into the basket. Hence, they would leave a signature in the form of a particular style or technique. To take the argument further, it is appropriate to look for that signature and test it against the connection between makers' styles and objects that are known, as has been done here. If this spiritual and artistic connection can be made with what is known - the data examined then it is reasonable to conclude that the other baskets represent similar stories.

\section{Adele, Wet'suwet'en Carrier Basket Maker}

Archival information has helped to identify a Wet'suwet'en Carrier basket maker. The excellent quality of her workmanship is demonstrated in consistency of design in her basketry which stood out among those studied. Barbeau identified her as Adele from Hagwilgate (ca.1920-21) (see Plate 19). Sufficient documentary evidence was found through archival research to learn some of her story.

Barbeau recorded the name Adele as the Wet'suwet'en Carrier basket maker when he purchased five of her birch bark baskets ${ }^{40}$ (CMC VI B 62 to CMC VI B 66). He stated, in item " 28 . Birch-bark basket, new, made by an old carrier woman, who sells them at Hazelton, in the Summer, named Adele, a [sic] Hagwelgate Carrier." ${ }^{41}$ He did not 
interview Adele to elicit the salient features of her basketry though he noted the name of her community. The design, construction and signature were found to be the same in all five baskets, thus strongly suggesting they were made by Adele.

Barbeau bought the baskets at R.S. Sargent's general store and post office in Old Hazelton, British Columbia (see Plate 7). Old Hazelton is located three miles from the Hagwilget reserve where Adele lived. Basketry was often purchased from general store merchants as basket makers turned to the local merchant to sell their basketry in the early twentieth-century. ${ }^{42}$

Barbeau noted that Adele was "an old Carrier woman." hundred photographs that he took are identified as being of Adele (see Plates 18 and 19) in his correspondence with E. Sapir of the National Museum in Ottawa. ${ }^{44}$ In the first photograph (see Plate 19), Adele is seen with her baskets in front of Sargent's store. A second photograph (see Plate 20) shows her trading her baskets with Sargent. Thus, Barbeau must be credited for taking the only known photographs of any of the producers of the basketry analyzed in this study. ${ }^{45}$

Evidence could not be found, however, that Sargent recorded Barbeau's transactions in his ledger books where other details were mentioned of transactions in handicrafts and fabrics. I scanned the ledgers in the Hazelton Pioneer Municipal Archives during my field trip to the Hazelton area in 2000. Sargent was known to have purchased basketry from native women between 1910 and 1940, long-term Hazelton resident Ward McKenzie (ca.90 years of age) informed me. ${ }^{46}$ There was evidence in Sargent's ledgers of money being received or paid out apparently in relation to Wet'suwet'en basketry sales, 
also confirmed by historian Douglas Cole (211). Of well-known visitors to Hazelton, the only person of interest here mentioned in the ledgers during the early and mid-1920s was Harlan I. Smith. He had Account No. 148 with Sargent. Two entries reflected trade: August 31, 1926 at $\$ 16.25$ and September 30,1926 at $\$ 15.90$. Sargent's Sundry Accounts also reflected transactions in handicrafts and fabrics in sales at both his Smithers and Hazelton stores on two occasions in October and December 1925, and three in February 4, each at $\$ 8.28$; on March 18,1926 at $\$ 77.18$; and 31 st at $\$ 75.43$. These transactions could have involved purchases of basketry. ${ }^{47}$

In researching Adele's history, information was found in the first Canadian Census at Hagwilget in 1901, likely recorded by local priests or the Babine Agency Indian Agent, Richard E. Loring (d.1934, Victoria, British Columbia). The Census ${ }^{48}$ identified a woman as "On-dell, wife of Charles and mother of Jennifer." The name On-dell can reasonably be assumed to have been a baptismal name. Many aboriginal people were given French names because most of that area was missionized by Roman Catholic priests.

Cassidy (1987: 43) referred to the arrival of members of the Royal Commission on Indian Affairs in 1915 at Hagwilget (Tse-kya) (Cassidy, 4) and their meeting with a "chief Charles." A subchief Charles was listed in the records of the Department of Indian Affairs. ${ }^{50}$ Thus, it is plausible that Chief Charles could have been the husband of Adele on the basis that no other Charles was listed in the 1901 Census other than the husband of Ondell. It was the custom in some aboriginal traditions that aboriginal women were given their husband's first name as their surname. This was also the case with Nlaka'pamux Spuzzum people, "when a daughter married she took her husband's first name as her 
surname" (Laforet and York 1998: 145). Because the Chieftainship is a hereditary one, the woman Chief identified in the record may have been succeeded by Adele's husband Charles in 1915. Or, he may have been a Subchief, as described by Fr. A. Godfrey, OMI. (f.n. 9). Indian Agent R.E. Loring, who had allocated the [sic] Wet'suwet'en Carrier Reserve planned lots, ${ }^{51}$ made reference to a Subchief Charles in relation to the agreement with twenty-six men from $T$ se $\mathrm{Kya}^{52}$ in exchange for not interfering with their traditional fishing activity at the canyon when a high level bridge was planned for building across the Bulkely River at the Hagwilget Canyon (Fiske and Patrick 2000: 36). Fiske and Patrick also pointed out (36) that, when the Department of Indian Affairs established the reserves at Hagwilget and allocated lot plans through Loring, they "drew administrative boundaries that joined the Babine communities with those of the Witsuwit'en [sic] in a single unit the Hagwilget." More precisely, Fiske and Patrick (36) referred to an "initial assessment of reserves to the Hagwilget," as the various communities were collectively labelled ..." Thus, I believe that Adele may have come from the nearby Kispiox Gitksan Reserve located a few miles northeast of the Hagwilget Wet'suwet'en Reserve which suggests intermarriage.

Finally, corroborating evidence for Adele's identity came from the records of Indian Status Card numbers for Hagwilget. ${ }^{53}$ In 1918, Number 181 was assigned to an "Adele Charles." Subsequent research has not yielded further information.

In his correspondence, Barbeau noted other baskets he bought that are now in the CMC (CMC VI B 129 to 132). ${ }^{54}$ For the CMC baskets (CMC VI BI37 and CMC VI B 334) he noted, "[a] list of specimens collected in summer of 1923, by C.M. Barbeau in the Upper Skeena Country, B.C., (mostly [sic] Gitsan specimens)." As well, "from a carrier 
woman: No. 57, VI I 170 - Birch bark basket, (large), with patterns. No. 58, VI I 171 - Birch bark basket, (smaller), (bought at R.S. Sargent's store)." these baskets do not link to Adele's baskets as they are dissimilar in construction, design and signature.

In annotating an earlier collection that Barbeau gathered in July and August, 1920, now in the CMC (CMC VI B 141 and CMC VI B 333), he wrote that the first basket was collected at Hazelton or Kisgegas [sic], one of the aboriginal communities near Hazelton. For the second basket he wrote, "[item no.] 280. Birch-bark basket or box, made many years ago, presumably by a Hagwelgate woman, with designs. From Emma Wigoble (Hazelton)."

\section{Subarctic Algonquin Basket Makers}

In the same period as Barbeau and Smith were in the northern interior of British Columbia, ca.1920, Frank G. Speck was engaged in field work with the Algonquin people in Quebec on behalf of the New York Museum of the American Indian, Heye Foundation. He, too, based his approach on interviews with basket makers because he (1937: 48-9) believed it was a more credible approach than simply working with basketry stored in museum collections. However, he (1937) did not reference any Montagnais basket makers by name. In his research in Algonquin basketry (ca.1941), he gathered information from a "half-dozen" informants whom he identified as unnamed women from the MacDougal and White Duck families. He included specific information obtained from only two identified 
Algonquin basket makers, Mrs. Michele Buckshot, Mackusi- ' $k$ 'we, and Madenine Cesar (Mrs. Clement) (ca.1941: 141-142).

He did include the basket maker's name with a few baskets sent to the National Museum, even though they did not match those that he referenced in his monograph. Baskets collected by Edward Sapir included the basket maker's names, for example, Catherine and E. Michel of Rivière Désert.

Speck (ca.1941: 235) also noted that the Rivière Désert families valued each other's baskets as he found several baskets in their homes that had been made by the other basket makers.

\section{Complexities for Basket Makers after European Settlement}

Madeline Johnny confirmed that Carrier women often folded and stitched birch bark basketry "on the spot" using traditional knowledge. She illustrated the point by explaining how she used a self-sealing pitch made from salmon eggs for sealing the seams of the basket.

Madeline Johnny learned birch bark basketry skills and techniques in a similar way. She copied her mother's and grandmother's designs during the times they were in the bush for berry picking and fishing. Mrs. Johnny was eight years old when her mother died. At that time, she was taken to residential school. She has been married to Alex Johnny for many years and together they have raised twelve children. Their surviving children are daughters who are now grandmothers themselves. Mrs. Johnny worked in a nearby hospital for eight years and then raised her grandchildren. Today, her baskets are designed 
exclusively to attract sales. She teaches her birch bark basketry to young people at Stony Creek in the traditional way of her ancestors.

Bernie McQuary noted that, when she was young, children sat and were silent. They just listened, she said. She knows why now, because she remembers what the elders used to say. Later in our interview, she invited me to accompany her upstairs to her bedroom closet. She asked me to retrieve a cardboard box high on the closet shelf that she normally did not let anyone see. As directed, I brought the box downstairs and Mrs. McQuary opened it. In the box were several baskets made by her mother, Agnes George, (a style that confirmed for me that RBCM 7070 was made by Agnes George), and some tools that she had used in her basket making. The box also contained a six-inch basket that Bernie McQuary said was her mother's “catch-all basket” similar to RBCM 19282. Mrs. McQuary said that her mother left the bottom of the basket rough because she had made it for herself. A berry basket similar to RBCM 8738 was in the box that was "hung around your neck" when berrying, she explained. There was one other small and very old basket similar to RBCM 19282 along with some spruce roots and a sap-scraper of the form illustrated in Teit (1905: 780). It was very worn from much cleaning. ${ }^{56}$

The sap scraper was used for scraping Jack Pine sap and possibly fibrous material such as birch bark and spruce roots. It was made from caribou-antler bone (781). Two bone knives, one made by her parent's uncle, and another by a great-uncle that Bernie McQuary estimated to be 200 years old, were also used for collecting Jack Pine sap in the Spring. The sap was eaten to cleanse the digestive system after the long winter months, Bernie explained. The larger implement, she explained, was used for removing birch bark. 
It looked similar to a boomerang and was made from the sinew of the back bone of an animal. Mrs. McQuary confirmed that she had made baskets and used horse hair on the rim for decoration. See CMC VI B 132-5 for an example of Carrier basketry with horse hair decoration on the rim. Mrs. McQuary said that she had attempted to sterilize the hair by putting it in boiling water, but it "shrivelled up and it had to be thrown away" she said.

Mrs. McQuary is said to be the last surviving person in her family and community to speak the Carrier language. She provides verbal and written translation services in legal circumstances on behalf of her people when necessary. She also taught English to her grandchildren. When Mrs. McQuary was in residential school, she explained, that she used to speak her Carrier language with her fellow students in the corner. When the nuns were coming, she said a code word Azday. They would slip into English. This was an example of her spirited personality.

Bernie McQuary remembered when her mother, Agnes George, "peddled the [baskets] around the nearby town of Vanderhoof to buy used clothing" out of necessity. Ethnographic research revealed that the Georges sold their basketry for cash to persons such as Wilson Duff, to other museum staff, and to travellers (see Appendix Five, Ethnographic Notes).

Baskets continue to be sold today. Basket makers such as Madeline Johnny continue to make and sell their basketry today. When we met, the Johnnys had recently attended an aboriginal elder's conference where Mrs. Johnny had taken her baskets to sell at the conference. She had a few left over and offered to sell one to me. I also found her basketry for sale at the Prince George Native Friendship Centre along with baskets made 
by Harold Thomas, Mary Thomas' son.

Based on the items in the collections, subarctic basket makers demonstrated excellence in quality and workmanship in their basketry, whether they made it for their own use or for sale. This can be seen in the patterns in the stitching on the rim and attractive geometric designs, or in representative and stylized floral designs.

Today, an example of the current marketing of Carrier products can be is found at the K'San Historical Village. When I visited K'San, the Executive Director, Laurel Mould explained that she had recently purchased basketry and had more on order from Agnes George's granddaughter, Bernie McQuary's daughter, Noleen McQuary. Ms. Mould was planning to use them in the historical exhibits throughout the K'San complex. ${ }^{57}$ It appeared that Noleen McQuary was the only young basket maker of Carrier basketry today. Her basketry was also for sale in the K'San gallery and gift shop. I also observed that historic Fort St. James, located near Vanderhoof displayed Carrier basketry similar to those studied, in the exhibit cases, the replicated store and other rooms in the historic museum.

Since post-European settlers built homes and farms, and established industries such as logging in the Carrier and Algonquin/Montagnais subarctic regions of Canada, it became increasingly difficult for basket makers to find large birch trees from which to gather bark. Today, basket makers are challenged by this lack of suitable trees. Madeline Johnny explained that she had to travel far north of Stony Creek, approximately sixty miles, to find trees with suitable bark today. I was unable to consult with Algonquin/Montagnais birch bark basket makers in this respect.

Turner (1992: 5-7) stated that aboriginal women are the first to explain the 
ecological state of the land from which they gather their materials. Thus, the reason for loss of materials to produce basketry may be variously due to

(a) cutting of trees by industrial logging.

(b) demographic changes in communities, i.e. increase in non-aboriginal population.

(c) conflicting uses of land and resources.

(d) the impact of herbicides and insecticides used in the forests that has created toxic conditions for basket makers in handling their traditional materials.

(e) deeded property ownership.

(f) designation of park land by governments and regional conservation societies.

(g) construction of dams that change the ecology of the land and flood areas where birch is found.

\section{Contemporary British Columbia Basket Makers}

Mary Thomas (see Plates 14-17) continues to make as well as to teach others how to make her traditional birch bark baskets. She explained that she learned basketry from her maternal family and that it has sustained her life. Recognition of her lifetime contributions that emerged from her subsistence work to the prestige she holds today is similar to that of Mohawk basket maker Mary Adams (Thornburn 1999).

Since Mary Thomas' early years of making baskets, she has worked tirelessly to help her people learn and be proud of themselves, their heritage and their traditions. She told me of her own personal struggle in finding happiness, faith and the peace of mind to believe in herself. In 1970, Mary Thomas was a consultant in the construction of a kekuli or winter dwelling at Neskonlith Reserve No. 3. She enlisted financial support from the private and public citizens for the cause of aboriginal land, environmental, and aboriginal issues through education. Mary Thomas had just received the 2001 Aboriginal Achievement Award when we met. She proudly showed it to me while a crew from a local 
television station was filming her for a feature broadcast in Salmon Arm. Mary Thomas was especially pleased because the award was given by her own aboriginal people. She was also designated as a "Woman of Honour" and an elder of the Neskonlith community. The Salmon Arm Museum named Mary Thomas the most significant citizen of 1991 .

Although few women are making birch bark baskets today, some men have taken up their production. Mary Thomas' son, Harold Thomas, produces birch bark baskets, having been taught by his mother. Similarly, a few Algonquin and Montagnais men make birch bark basketry today as I noted through observation at festivals and cultural centres in Ottawa and Montreal (1998-99).

\section{Family-Based Learning}

Family-based learning teaches every aspect of traditional knowledge to members of the aboriginal family according to their age and sex, beginning at the moment they are born. In our interview, Mary Thomas ${ }^{58}$ explained

"when a baby was in its mother's womb, it is kicking and moving, but the minute it is born, it is bound in that little cradle and the mother carries the baby with her wherever she goes....you know the child has to learn. It might cry one or two days, but that child knows it is beginning to know that it has to go with its mother, it has to be cradled. You are teaching it selfdiscipline."

Turner explained (1996: 1) that, in the traditional economy, harvesting or gathering the materials for basketry was a process based on traditional ecological knowledge. In turn, it was an "integral part of the daily lives of aboriginal people." It included traditional aboriginal philosophies, attitudes, values, and practical knowledge. The knowledge of 
basket making was passed down from generation to generation by grandmothers, aunts, mothers, and sisters, mainly through observation and participatory learning. Sometimes, the technique was taught in a systematic way, but when living on the land, the practical method of learning was through observation.

Mary Thomas further explained

"when a little girl started walking and try to imitate adults in our strong family circle, the first thing a grandmother would make is a tiny little picking basket for the little girl and tie it around their little waist. They would fill it with dirt, leaves or anything. But, lesson number one is learned by that little child, that this is a container and it is going to have to be filled, so when she gets older, her basket gets a little bigger and she is expected to fill it at least once before she can go play. So the lessons too, it was always a must with our people."

Mary Thomas also referred to learning how to make her traditional basketry, including images incised on them, and what that basketry meant.

"The ones that I saw were mostly leaves or flower like, you know they just sort of drew imitations of. I asked my mother, she died at 102, and my aunt at 103, and they were my inspiration. I learned so much from them. I was asking my mother, what does the designs resemble? She said, "this is a berry picking basket and it reminds you of your respect for those berries and you put your leaves or you draw your design on your basket." So it had a lot of meaning to our people."

Turning to the experiences of other contemporary basket makers, another prestigious aboriginal basket maker whom I interviewed was Rena Bolton (1928-). Since her marriage to Tsimshian carver Cliff Bolton in 1970, they have lived near Terrace, British Columbia. Rena Bolton was taught the art of basket weaving beginning in 1930 by her grandmother in the traditional way of the Coast Salish people. She is a hereditary carrier of their traditions and heritage. As other basket makers have had to do, Mrs. Bolton made 
baskets to put food on the table for her family. In the fifteen years during which she researched traditional Tsimshian weaving with wool and bark, Rena Bolton would take a basket apart to learn how it was made so she could teach it to basket makers in their communities. She stated that it was often far more difficult than she had imagined. In our conversation, Mrs. Bolton also confirmed that, in the past, the Tsimshian people did in fact make birch bark basketry. ${ }^{59}$

From 1969 to 1970, Rena Bolton travelled throughout British Columbia in an effort to revive the traditional work of her aboriginal people. In 1985, she began her first cedar bark (Thuja plicata) weaving course after the aboriginal potlatch became legal in 1951. As a grandmother, she has worked tirelessly to inspire aboriginal people to carry on their cultural traditions through art and craft. Rena Bolton is internationally recognized for her basketry that is now in museum collections and art galleries. She too has received many awards and honours.

Rena Bolton commented on how difficult she found it was to get cedar bark, and it was even more difficult in gathering spruce roots of good quality. She has to go far into remote areas to find these materials. Now that she is older, her husband accompanies her.

A Coast Salish basket weaver from Washington State, Pauline Joe, explained that her grandmother had stressed that she learn how to make their good quality traditional baskets. Pauline Joe recounted that was why she often had to redo her work. She now appreciates her grandmother's efforts as she too recognizes that the production of aboriginal basketry has declined. Her sisters regretted they didn't learn how to make their traditional basketry, but they admire their sister for continuing to make her baskets. 
Pauline Joe also commented that in some ways aboriginal women have adapted to the new way of life in the European society and they did not want to keep the old ways including making baskets. ${ }^{60}$

Pauline Joe moved to Duncan, British Columbia when she married her husband, who is of Nuu-chah-nulth ancestry. She explained that when she is preparing her basketry materials, she finds and peels a flawless thirty-five foot strip of cedar bark. This is a special time for Mrs. Joe. She gathers the bark from second growth cedar trees that are six to eight inches in diameter. As other aboriginal basket makers explained to me, they always gave thanks through prayer to the tree for the bark they will remove. When Pauline Joe gathers her bark, she visualizes what she will make from it. Today, like other aboriginal basket makers, Pauline Joe fishes, knits and weaves baskets “just to survive."

Pauline Joe makes "canoe bailers" of cedar bark in addition to her cedar bark basketry. She finds these useful items sell better than simply decorative basketry. The canoe bailer is a competitive product made by aboriginal men. Her style of construction she learned from her grandfather has been copied and sold for a higher price by her male competitors. This example mirrors the lack of appreciation for aboriginal women's Northwest Coast work when compared with Northwest Coast carvings made by aboriginal men.

Pauline Joe travels to her home state of Washington, United States to gather her grasses at the present time. A United States permit is required because her traditional harvesting is now in an environmentally protected area. In the Duncan, British Columbia area, Mrs. Joe enlists support of friends in the logging industry as the forestry industry has 
made it difficult to gather cedar bark. They assist her by telling her where there is good bark. Sometimes they take her there or collect and bring logs to her home. Thus, the present state of the environment is reflected in the environmental impact on aboriginal basketry in these examples.

Kathy Edgar was the youngest of the basket makers with whom I had interviews. She is from the remote Nuu-chah-nulth Ditidaht community on the west coast of Vancouver Island. Her cedar basketry and covered bottles were a contemporary example of Nuu-Chah-Nulth weaving in the HuupuKwanum-Tupaat Out of the Mist - Treasures of the Nuu-chah-nulth Chiefs Exhibition at the Royal British Columbia Museum, 2000 ${ }^{61}$ Kathy Edgar's mother, Frances Edgar, aged seventy-six, continues to live at Ditidaht but weaves only cedar bark now that her eye sight is failing. Kathy Edgar produces traditional fine cedar bark and sea grass weaving taught by her mother beginning at age twelve mainly through observation. Similar to other aboriginal basket makers discussed, Kathy Edgar explained that Frances Edgar learned her own basket weaving at age eight by observing her mother or aunts. Kathy Edgar and her mother have been criticized by basket weavers in their own and neighbouring Cowichan communities for sharing their traditional knowledge through teaching cedar woven basketry to non-aboriginal women.

\section{Basketry in Present Times}

All of the basket makers interviewed drew attention to the impact on their work with respect to tourism. Since early in the twentieth century, travellers into British 
Columbia looked for "native" souvenirs of their journeys. In fact, during the 1930s, travellers were encouraged to travel west by the Canadian Pacific Railway marketing their newly constructed railway line. In its promotional brochures the company cited the availability of the Northwest Coast Vancouver Island basketry as a feature of the journey (Turner 1996: 25).

Appreciation and demand for aboriginal basketry by non-aboriginal Canadians is greater today than ever in the past. In my own observations, the Canadian Museum of Civilization in recent years has fostered opportunities for the Algonquin and other aboriginal people to sell their art to the general public such as during National Aboriginal Day events. The basket makers also sold their work at the Ottawa Native Friendship Center, pow wows and other festivals in the Ottawa area. At a pow wow on the Mohawk Kahnawake reserve near Montreal, Quebec, I observed an Algonquin family from Barriere Lake, located north of Maniwaki, selling their birch bark basketry. ${ }^{62}$

It is no longer possible to purchase high quality basketry made by aboriginal women for a few dollars, as it has reached affluent collectors of aboriginal art. This has made the basketry a valuable commodity to a small segment of society. Baskets can sell for sums ranging from sixty to ten thousand dollars or more, depending on the status that the basket maker has achieved through quality and design. Examples of the latter are the works of Rena Bolton, and Haida basket maker Isabel Rorick. The basket makers though, do not always receive the full value of their product when sold in art galleries and museum shops. However, basket makers are willing to make baskets on a commissioned arrangement where they are able to receive the full value of their work. 
The stories of the basket makers, Madeline Johnny, Bernie McQuary, and her daughter Noleen McQuary; Mary Thomas; Rena Bolton, Pauline Joe, and Stella Johnny reflect the adaptability of aboriginal women to changes in society in the twenty-first century.

In addition to exposing their traditional art to the world, some contemporary basket makers such as Madeline Johnny, Mary Thomas, Rena Bolton, Pauline Joe and Stella Johnny are endeavouring to teach aboriginal basket making in all of its aspects to young people and other interested women in their communities. Mary Thomas has produced a video that highlights basket making and basketry to bring attention to the environmental impact on her traditional lands because it affects her people and their basket making.

Conferences are organized by the Washington and Oregon state aboriginal basket makers, Northwest Native American Basketweavers Association, where they can learn about making traditional basketry and exchange new techniques taught by their peers and elders. Trade in basketry materials is another key component of the conference. The aboriginal basket makers are holding these conferences in an effort to retain Northwest Coast basketry traditions. The organization now includes a startup Vancouver Island branch at Duncan, British Columbia.

Conversely, in the Cowichan Coast Salish community, teaching of basketry is a closed and private system amongst most aboriginal basket makers. The Cowichan basket makers consider their basketry to be their cultural knowledge and property which they do not want to lose. As a result, they do not share their methods of basket making with non- 
Chapter Five / 125

aboriginal people. This position in part is a reaction to their experiences in the residential schools and the desire to reclaim their traditions. ${ }^{63}$

Memories and commentaries of aboriginal basket makers living in British Columbia have provided a personal perspective on circumstances only sketched in the historical documents and have introduced new issues. These are issues of identity; retention of cultural knowledge, environmental concerns, quality of the product, attention to detail (remaking, studying); and availability of materials required in the production of basketry now gradually diminishing. 


\section{Chapter Six}

\section{CONCLUSION}

This chapter concludes the thesis with a synopsis of the important information that has been developed and why it is significant in the context of subarctic Carrier, Algonquin and Montagnais birch bark basketry. It also considers some gaps in the existing literature and desirable future research on the topic of Canadian aboriginal basketry.

This thesis has presented an empirical comparison and comparative analysis of the birch bark basketry made by Carrier and Algonquin and Montagnais people collected in the late nineteenth and early twentieth century.

This topic was explored because very little information was available in the historical record about subarctic birch bark basketry, Carrier and Algonquin/Montagnais basketry, or the basket makers of these regions. This augments the record and places the basketry more securely in its ethnographic and historical context, and enables unattributed baskets to be placed, with some assurance, in their proper context. The thesis tells a richer narrative about birch bark basketry than has been available to date. This is supplemented by the perspectives and accounts of certain basket makers, including a number of living elderly basket makers.

Birch bark basketry is a relatively modest technology. Algonquin/Montagnais and Carrier basket makers follow the same general process of manufacture but with different 
results. From the formal analysis it is possible to identify the features of these distinct styles of birch bark basketry. Neither collection has adequate documentation for the analysis although helpful insight has been provided by two Carrier basket makers, one of whom continues to produce Carrier birch bark basketry. My ethnographic research with respect to the RBCM collection contributes to the provenance of many of the Carrier baskets.

The basket makers in both regions have experienced the same colonial incursion with a similar response. At least three generations of basket makers and their families have been affected by the loss of their land, their resources, changes in trade, economic dependencies, differing social relationships, and from traditional ways of living to governments, churches, and settlers' ways of living. There was a large market for basketry, and only a few basket makers sell to a small market today. The colonial conflict between cultures continue and the same broad general concerns remain for the few basket makers that still create their art.

With the loss of access to traditional lands, resources and life-styles, the traditions originating from the land based seasonal way-of-life have diminished and are being lost as art forms. Only a few individuals remain to carry on the tradition. In the new Europeanbased economy, the traditional economies were replaced by a wage economy. Aboriginal people became economically dependent on others. Basket making did not continue to be an intrinsic part of the aboriginal peoples' way-of-life in the post European economy. The quality declined as evidenced by the comparison of the older and the newer subarctic basketry in the collection with that sold today. While a number of individual basket makers 
Chapter Six / 128

have not lost pride in their basketry, they find it difficult to continue production because of their increasing inability to obtain materials. This has been accompanied by the diminishing time available to produce their artistry in the new society.

These factors were reflected in the stories of my informants, four basket makers from the Carrier, Sto:Lo/Tsimshian, Secwepemc and Coast Salish cultures. Conversations with these basket makers, some of whom are elderly, indicated that they continue to place great value on their basketry as a remaining part of their spirituality, and their personal and cultural identity. This identity and pride are understood by their signatures that are found in the stitching on the ends of their baskets.

Directions can be suggested for further research. First, an in depth study of certain baskets may lead to further signs of regional identity. Second, time is short for recording the traditional knowledge of other elderly basket makers in person. It is important to document the history of their cultures, and their basketry in particular. This can be accomplished by interviewing basket makers to understand the context of the designs in their baskets through their stories and in documenting their stories.

The underlying research question that can be pursued is what leads anthropologists and art historians to make those categories of art or craft in relation to basketry?

Basket makers such as Rena Bolton and Mary Thomas face complex issues today relating to identity, the environment, and working with markets.

Subarctic birch bark basketry has not received much attention before now. This 
thesis contributes to the body of knowledge and establishes birch bark basketry as a field for further research. 
Appendix One

TABLES

Tables / 130 
TABLE 3. Carrier Basketry According to Collector

\begin{tabular}{|lc|}
\hline Collector & Quantity \\
\hline \hline C. Marius Barbeau & 12 \\
Mrs. G.M. Carter & 1 \\
Mrs. Charlotte Cox & 1 \\
Mrs. Helen Marion Dallain & 6 \\
Mr. Alan W. Ford & 1 \\
Wilson Duff/Maxine George & 3 \\
Mr. George Collection & 1 \\
Miss Hilda D. Harris & 1 \\
Mr. Houston Collection & 1 \\
Diamond Jenness & 2 \\
Dr. Oswald Meredith Jones & 10 \\
Mrs. Ursula Lalonde & 3 \\
Maynard's Auction, for RBCM & 1 \\
Mrs. Melba Menzie & 1 \\
Adrien Morice O.M.I. & 5 \\
Dr. Charles F. Newcombe & 2 \\
Mrs. W. Fleet Robinson & 4 \\
Mr. W.B. (Brown) Russell & 4 \\
RBCM Staff & 2 \\
Mrs. Dorothy Sherwood & 1 \\
Morley Shire & 1 \\
Harlan I. Smith & 63 \\
Mr. S. Smith Collection & 1 \\
Lt. Frank Cyril Swannell & 8 \\
Mildred Valley Thornton & 1 \\
Dr. W.F. John Tolmie & 2 \\
Tomlinson and Wood Collection & 1 \\
Mrs. Washington & 2 \\
Unknown provenance & \\
& \\
\hline
\end{tabular}


TABLE 4. Carrier Basketry According to Location Collected

\begin{tabular}{|c|c|c|}
\hline Location & Collector & Date \\
\hline Hazelton (Fort Fraser), Vancouver & RBCM Staff & 1974 \\
\hline Fort Fraser & Diamond Jenness & 1924 \\
\hline Hazelton, Bella Coola & Harlan I. Smith & 1925,1922 \\
\hline $\begin{array}{l}\text { Hazelton, Kisgagas, Hagwilget, } \\
\text { Upper Skeena }\end{array}$ & C. Marius Barbeau & $\begin{array}{l}1920,1920-1921,1923 \\
1925\end{array}$ \\
\hline Hazelton & Mrs. Charlotte Cox & 1976 \\
\hline Masset, Queen Charlotte Islands & Mrs. Dorothy Sherwood & 1919 \\
\hline Nautley Reserve (Fort Fraser) & Wilson Duff / Maxine George & $1951,1957,1960,1974$ \\
\hline Northern Dene & Mr. S. Smith Collection & 1961 \\
\hline Saik'uz Ts'eke (Stony Creek) & Mrs. Washington & 1931 \\
\hline $\begin{array}{l}\text { Saik'uz Ts'eke, Nadleh Whuten } \\
\text { (Nautley Ranch / Fort Fraser) }\end{array}$ & Lt. Frank Cyril Swannell & $1909,1917,1927,1930$ \\
\hline Skeena River & Mrs. Helen Marion Dallain & 1979 \\
\hline Upper Skeena River & Mr. Houston Collection & unknown \\
\hline Stuart Lake & Adrien.J. Morice, O.M.I. & 1892 \\
\hline \multicolumn{3}{|c|}{ Carrier Basketry Collected at Locations Unknown } \\
\hline \multicolumn{3}{|c|}{ Mr. George Collection, 1961; Tomlinson and Wood Coll'n., 1961; Dr. Charles F. Newcombe, 1962} \\
\hline \multicolumn{3}{|c|}{ Mrs. Melba Menzie; Morley Shire, 1957; Miss Hilda D. Harris, 1933; Mildred Valley Thornton, 1965} \\
\hline \multicolumn{3}{|c|}{ Mrs. G.M. Carter, 1970; Maynard's Auction, for RBCM, 1973; Mrs. W. Fleet Robertson, 1929} \\
\hline \multicolumn{3}{|c|}{ Dr. W.F. John Tolmie, 1927; Mrs. Ursula Lalonde, 1977; Dr. Oswald Meredith Jones, 1962} \\
\hline \multicolumn{3}{|c|}{ Mr. W.B. (Brown) Russell, 1991; Mr. Alan W. Ford, 1966} \\
\hline
\end{tabular}


TABLE 5. Acquisition Record for Carrier Basketry

\begin{tabular}{|c|c|c|}
\hline Accession Date & Collector & Location \\
\hline \multicolumn{3}{|l|}{ The CMC } \\
\hline 1892 & Adrien.J. Morice, O.M.I. & Stuart Lake \\
\hline 1919 & Mrs. Dorothy Sherwood & Masset, Queen Charlotte Islands \\
\hline $\begin{array}{l}1920,1920-21,1923, \\
1925\end{array}$ & C. Marius Barbeau & $\begin{array}{l}\text { Hazelton, Kisgagas, Hagwelgate, } \\
\text { Upper Skeena }\end{array}$ \\
\hline 1924 & Diamond Jenness & Fort Fraser \\
\hline 1922,1925 & Harlan I. Smith & Hazelton, Bella Coola \\
\hline \multicolumn{3}{|l|}{ The RBCM } \\
\hline $\begin{array}{l}1909,1917,1927,1930 \\
1945\end{array}$ & Lt. Frank Cyril Swannell & $\begin{array}{l}\text { Saik'uz Ts'eke, Nadleh Whuten } \\
\text { (Nautley Ranch / Fort Fraser) }\end{array}$ \\
\hline 1927 & Dr. W.F. John Tolmie & \\
\hline 1929 & Mrs. W. Fleet Robertson & \\
\hline 1931 & Mrs. Washington & Vanderhoof \\
\hline 1933 & Miss Hilda D. Harris & \\
\hline $1951,1957,1960,1974$ & Wilson Duff / Maxine George & Nautley Reserve, or Fort Fraser \\
\hline 1957 & Morley Shire & \\
\hline 1961 & Mr. George Collection & \\
\hline 1961 & Tomlinson \& Wood Collection & \\
\hline 1961 & Mr. S. Smith & Northern Dene \\
\hline 1962 & Dr. Charles F. Newcombe & \\
\hline 1962 & Dr. Oswald Meredith Jones & \\
\hline 1965 & Mildred Valley Thornton & \\
\hline 1966 & Mr. Alan W. Ford & \\
\hline 1970 & Mrs. G.M. Carter & \\
\hline 1973 & Maynard's Auction, for RBCM & \\
\hline 1974 & RBCM Staff & Fort Fraser (Hazelton), Vancouver \\
\hline 1976 & Mrs. Charlotte Cox & Hazelton \\
\hline 1977 & Mrs. Ursula Lalonde & \\
\hline 1979 & Mrs. Helen Marion Dallain & Skeena River \\
\hline 1991 & Mr. W.J. (Brown) Russell & \\
\hline unknown & Mrs. Melba Menzie & unknown \\
\hline unknown & Mr. Houston Collection & unknown \\
\hline unknown & unknown provenance & unknown \\
\hline
\end{tabular}


TABLE 6. Algonquin and Montagnais Basketry by Collector, Location and Acquisition Date

\begin{tabular}{|c|c|c|c|}
\hline Collector & Number & Location & Date \\
\hline Montagnais & \multirow[b]{2}{*}{4} & \multirow[b]{2}{*}{ Pointe Bleue } & \multirow[b]{2}{*}{1911} \\
\hline E. Sapir & & & \\
\hline F.G. Speck & 16 & Lac St. Jean & 1912 \\
\hline Algonquin & \multirow[b]{2}{*}{34} & \multirow[b]{2}{*}{ Maniwaki } & \multirow[b]{2}{*}{1912,1913} \\
\hline E. Sapir & & & \\
\hline \multirow[t]{2}{*}{ F.G. Speck } & 2 & Maniwaki & \multirow[t]{2}{*}{1912,1913} \\
\hline & 17 & LakeTemiskaming & \\
\hline
\end{tabular}

TABLE 7. Forms of Carrier Basketry in the RBCM

\begin{tabular}{|ccc|cc|}
\hline Tall Basket & With Open & Mouth & Shallow Open & Tray \\
\hline \hline Form A.1 & Form A.2 & $\frac{\text { Form A.3 }}{292}$ & 4470 & $\frac{\text { Form B.1 }}{\text { Form B.2 }}$ \\
4296 & 8780 & 9258 & 4299 & 4486 \\
4297 & 11552 & 9262 & 4300 & 10488 \\
4471 & 14970 & 10329 & 4469 & 10530 \\
4472 & 15916 & 10536 & 4485 & \\
7070 & 16234 & 10578 & 11478 & \\
8738 & 19280 & 11555 & 11546 & \\
10777 & 11072 & 11556 & 11547 & \\
11480 & & 12673 & 11551 & \\
11553 & & 12674 & 15918 & \\
12675 & & 14525 & 18179 & \\
13604 & & 18242 & 19277 & \\
14147 & & & & \\
16235 & & & & \\
16236 & & & & \\
16237 & & & & \\
16875 & & & & \\
17114 & & & & \\
19281 & & & & \\
\hline
\end{tabular}


Tables / 135

TABLE 8. Forms of Carrier Basketry in the CMC (VI B)

\begin{tabular}{|ccc|cc|}
\hline Tall Basket & With Open & Mouth & Shallow Open & Tray \\
\hline \hline Form A.1 & Form A.2 & Form A.3 & Form B.1 & Form B.1 \\
\cline { 2 - 3 } & 62 & 68 & 61 & 88 \\
64 & 91 & 70 & 69 & 107 \\
65 & 103 & 83 & 72 & 113 \\
66 & 104 & 86 & 73 & 115 \\
67 & 114 & 89 & 74 & 116 \\
78 & 117 & 93 & 75 & 118 \\
79 & 122 & 94 & 76 & 123 \\
80 & 124 & 95 & 77 & 126 \\
84 & 125 & 96 & 81 & 127 \\
85 & 141 & 97 & 82 & 128 \\
87 & 334 & 98 & 101 & 131 \\
90 & & 99 & 102 & \\
92 & & 100 & 119 & \\
109 & & 105 & 121 & \\
132 & & 106 & 333 & \\
133 & & 108 & & \\
134 & & 110 & & \\
135 & & 111 & & \\
137 & & 112 & & \\
140 & & 120 & & \\
331 & & 130 & & \\
& & 138 & & \\
& & 139 & & \\
\hline
\end{tabular}


Tables / 136

TABLE 9. Forms of Algonquin/Montagnais Basketry in the CMC (III L, III C)

\begin{tabular}{|cc|cc|}
\hline Square & Base & Rectangular & Base \\
\hline \hline Form C.1 & Form C.2 & Form D.1 & Form D.2 \\
ALGONOUIN & & & \\
20 & & & 11 \\
56 & 28 & 19 & 12 \\
57 & 30 & $34-44$ & 117 \\
100 & 31 & $46-52$ & \\
105 & & $54-55$ & \\
106 & & $86-7$ & \\
$110-11$ & & 98 & \\
116 & & $102-3$ & \\
& & $108-9$ & \\
& & $112-3$ & \\
& & 115 & \\
MONTAGNAIS & & & \\
163 & 440 & 161 & 449 \\
200 & & 167 & \\
201 & & $432-4$ & \\
436 & & $445-6$ & \\
& & 448 & \\
\hline
\end{tabular}


Appendix Two

MAPS AND ILLUSTRATIONS

Maps, Illustrations / 137 
Maps, Illustrations / 138

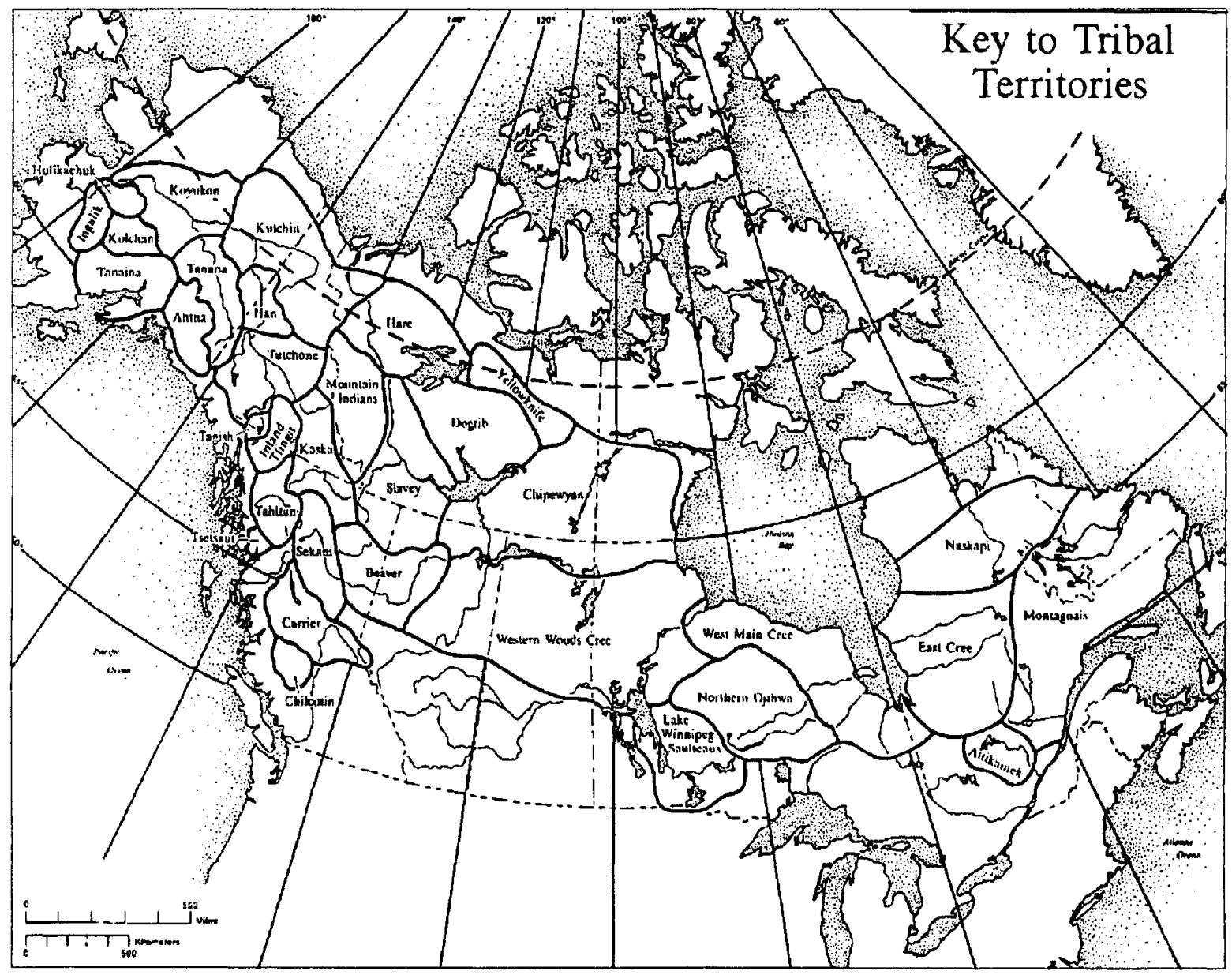

Handbook of North American Indian: "Subarctic," Vol. 6: ix (with permission)

MAP 1. First Nations of Subarctic Canada 


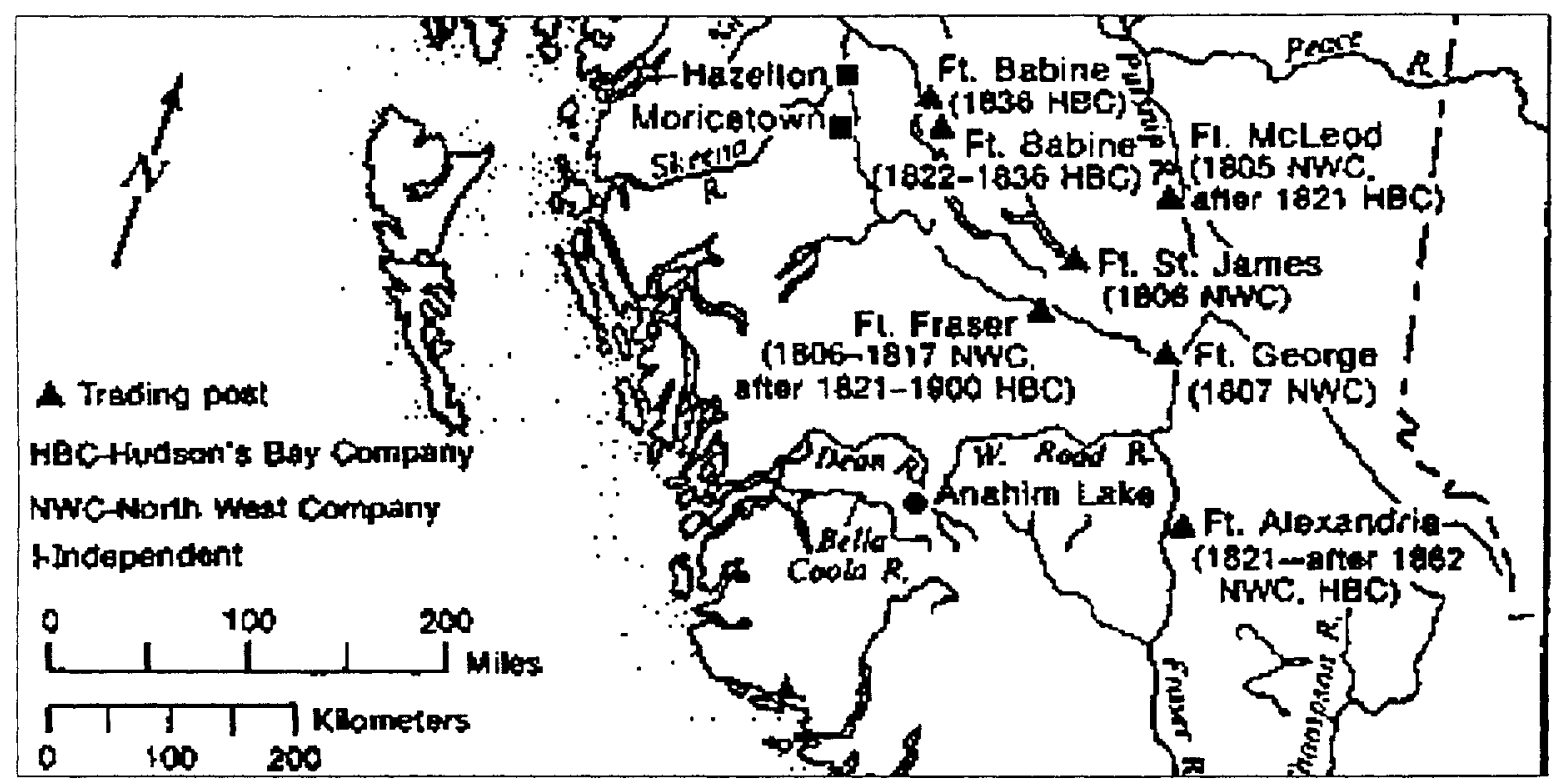

McClellan 1981: 389

MAP 2: "Trading Posts in the Cordillera ... with approximate dates when they were established and abandoned, when known." 
Maps, Illustrations / 140

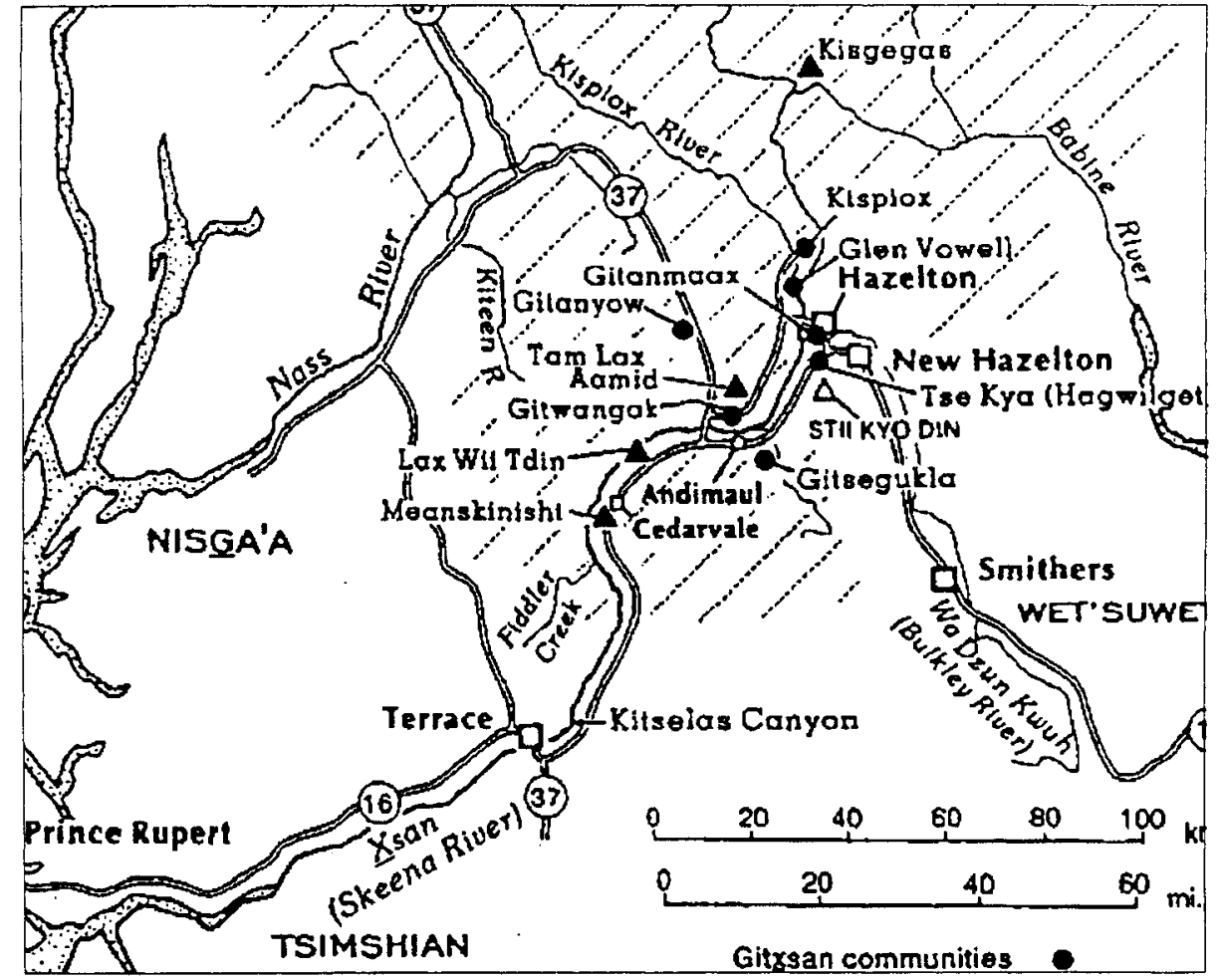

Cheryl Coull 1996: 178

MAP 3: Gitxsan Territories

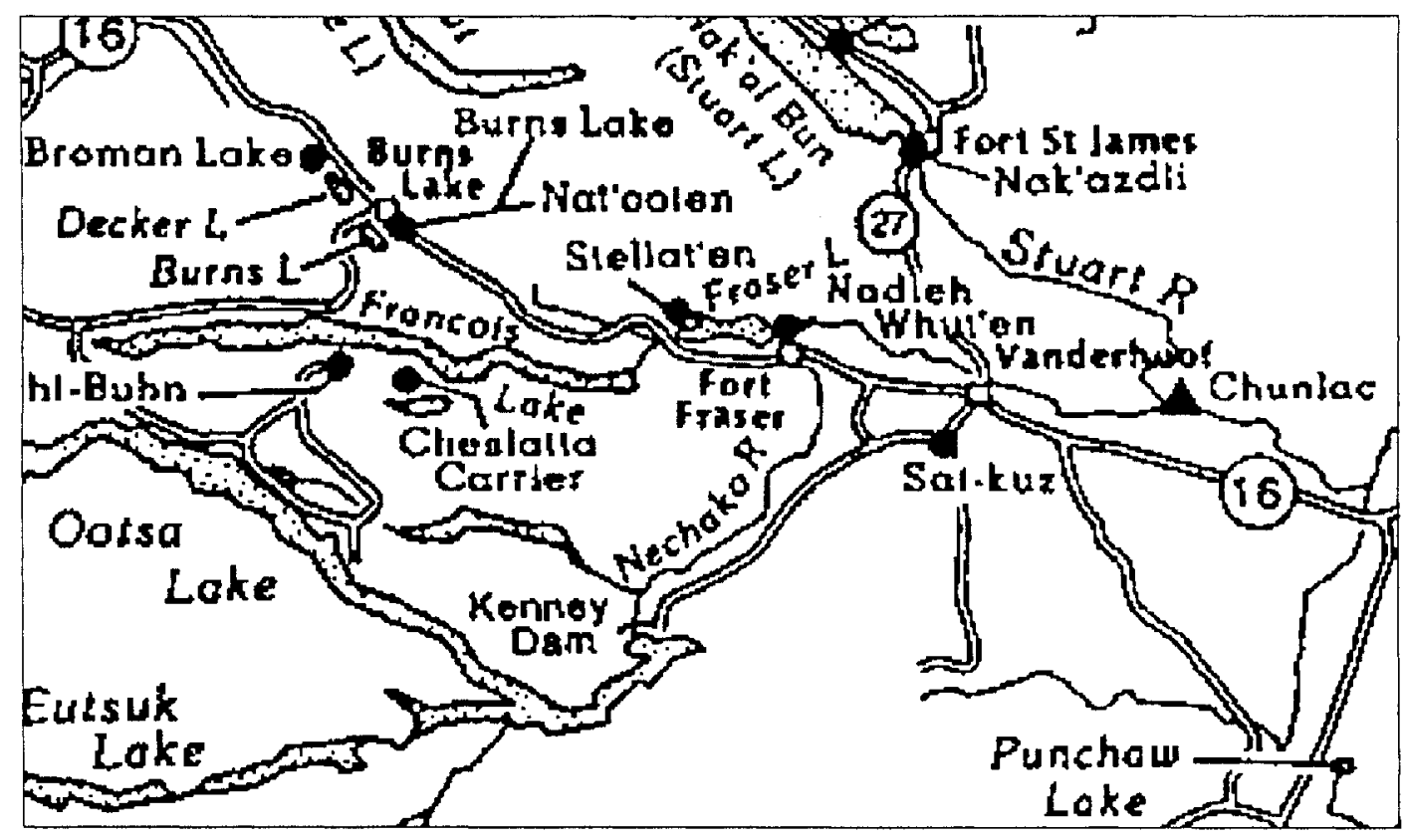

Cheryl Coull 1996: 156

MAP 4: Dakelh Territories; Central Carrier Communities 
Maps, Illustrations / 141

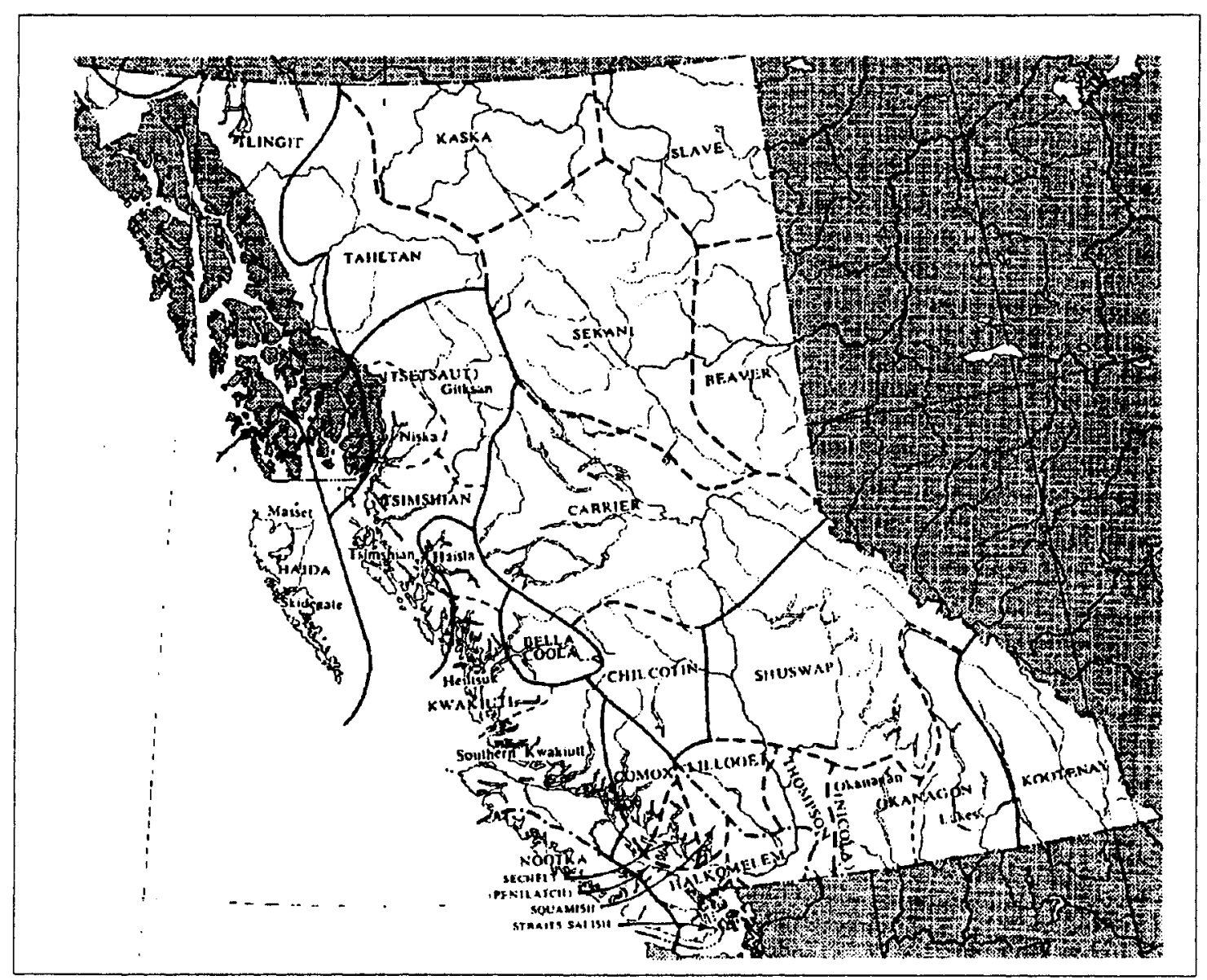

Wilson Duff 1992 [1997]: 23 (with permission)

MAP 5: Indians of British Columbia: Linguistic Subdivisions 


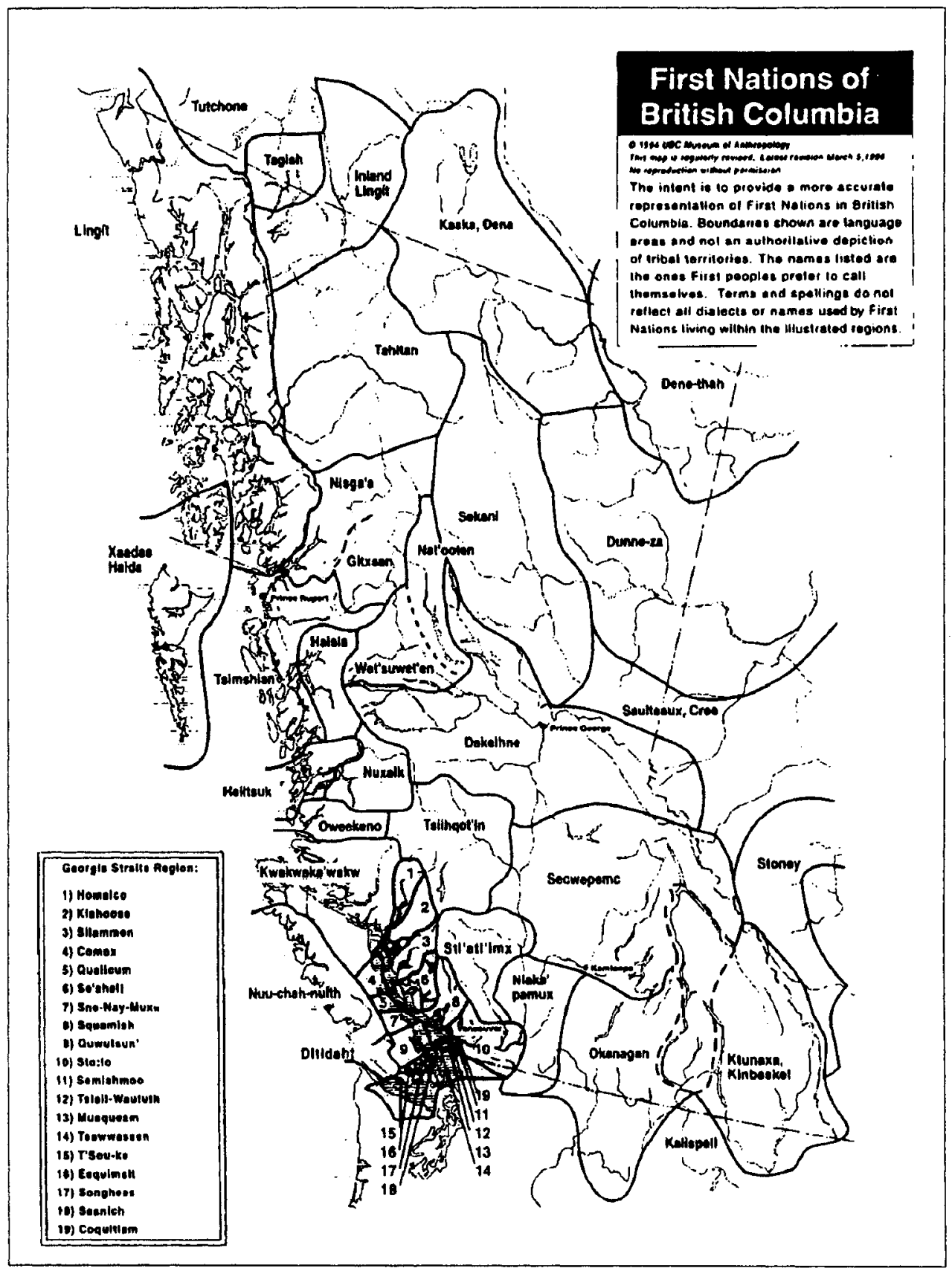

Wilson Duff 1997: 166 (with permission)

MAP 6: First Nations of British Columbia, 1996. 
Maps, Illustrations / 143

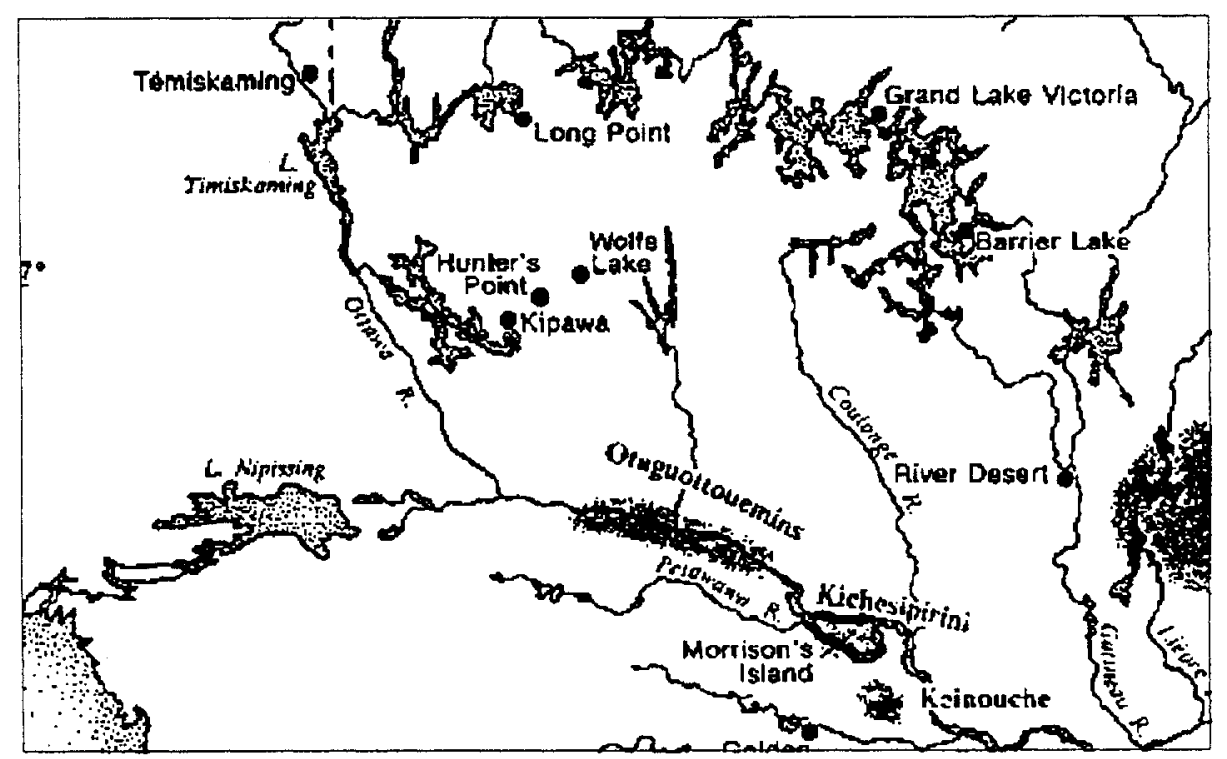

Handbook North American Indian, Vol. 15

MAP 7: Bands of the Ottawa valley in the early $17^{\text {th }}$ century and Algonquin reserves in 1970

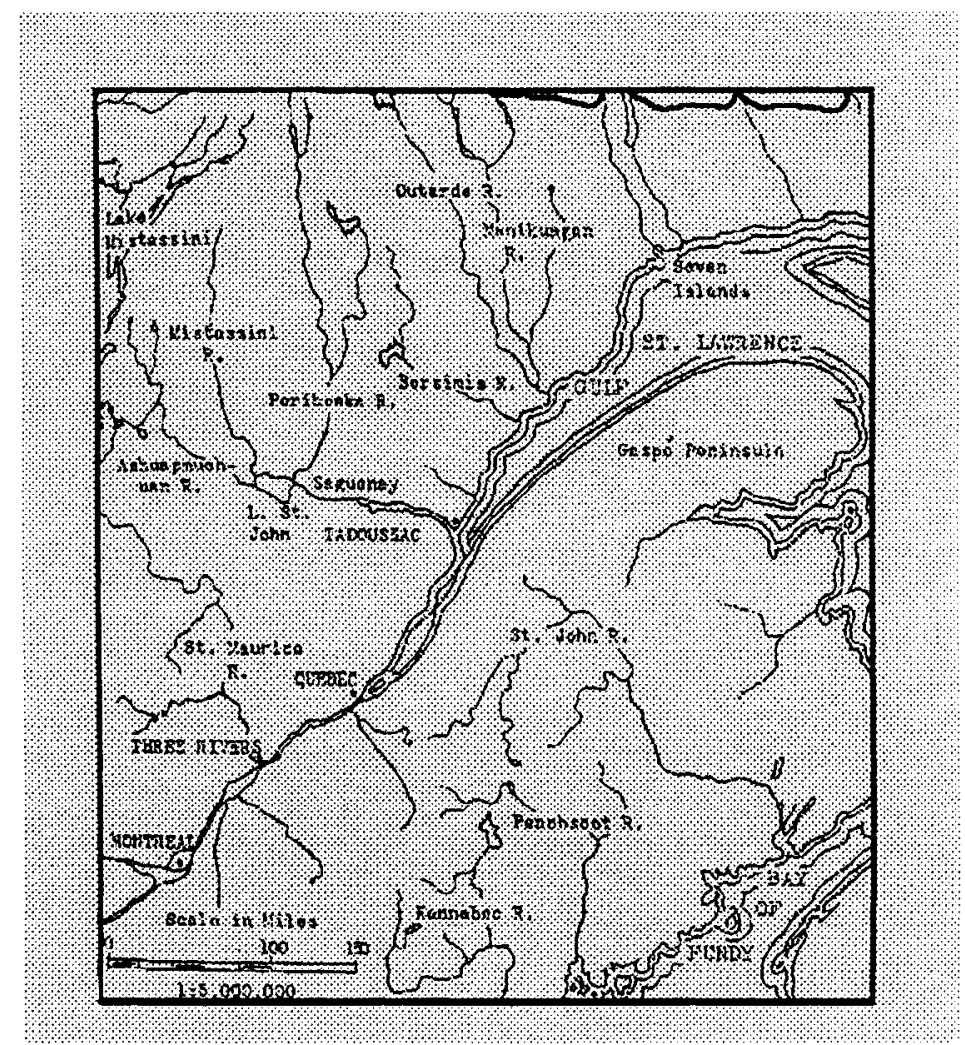

Lane, Kenneth S., 1952

MAP 8: Montagnais Communities 
Maps, Illustrations / 144

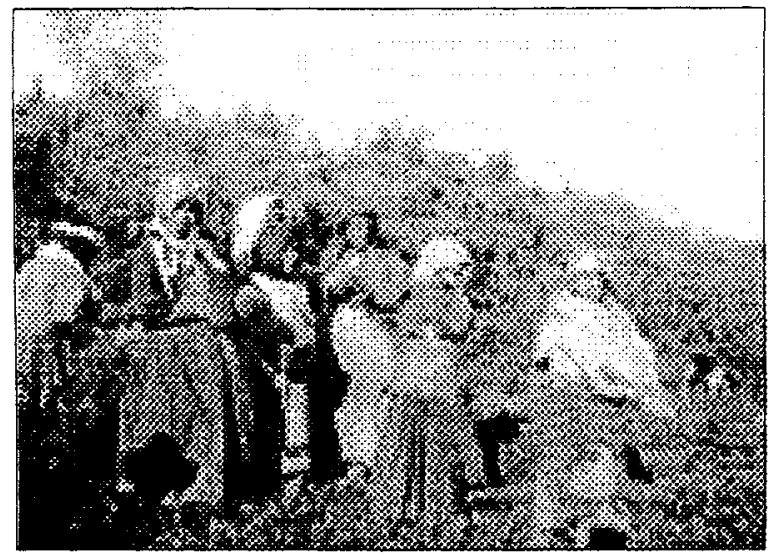

British Columbia Archives G-03734, F.C. Swannell

PLATE 1. Indian girls at Nulki Lake, 1908

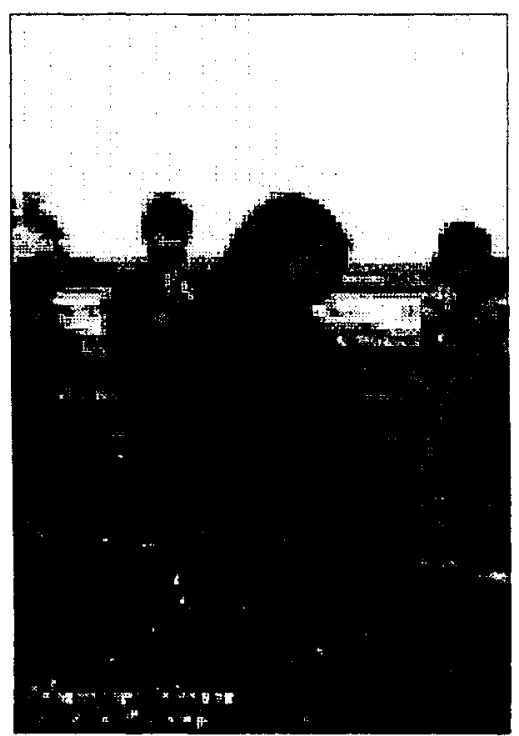

British Columbia Archives I-33184, F.C.

Swannell

PlATE 2. Indians cleaning

salmon at Stuart Lake 
Maps, Illustrations / 145

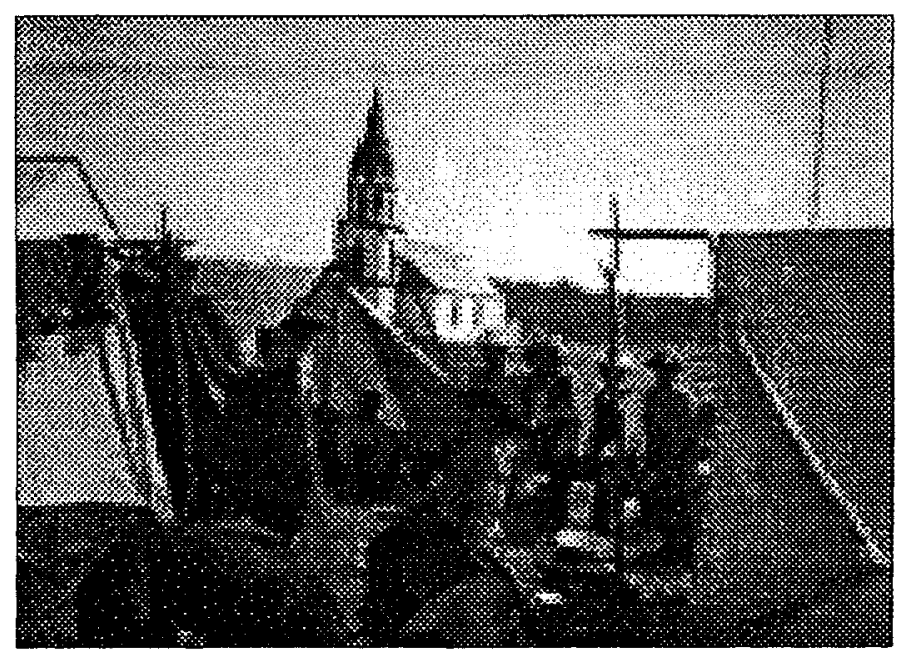

British Columbia Archives G-03880, F.C. Swannell

Plate 3. Stoney Creek Indian Church, 1908

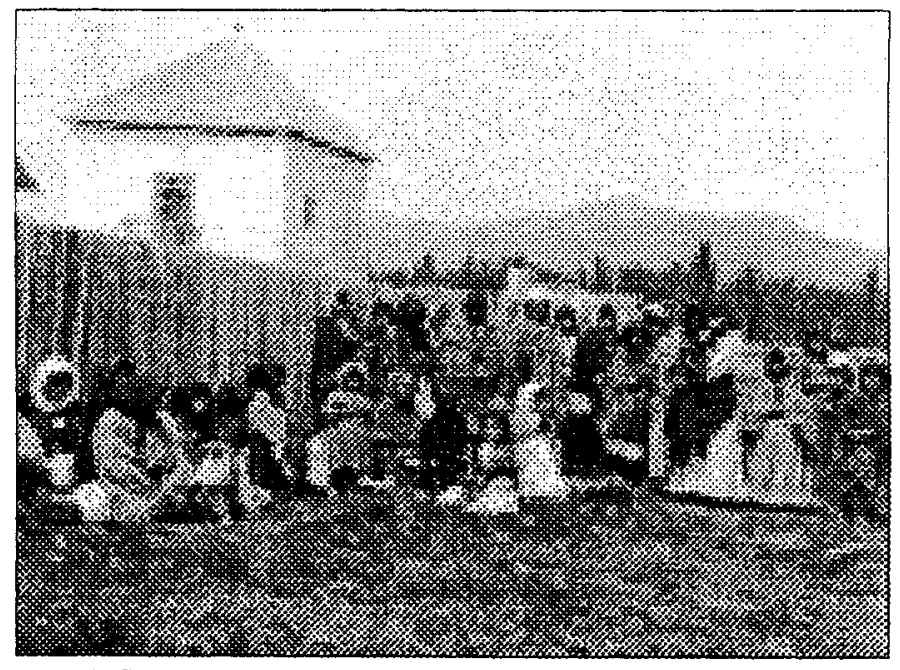

British Columbia Archives G-06397, F.C. Swannell

Plate 4 Fort St. James Indians at Dominion Day celebrations, 1912. 
Maps, Illustrations / 146

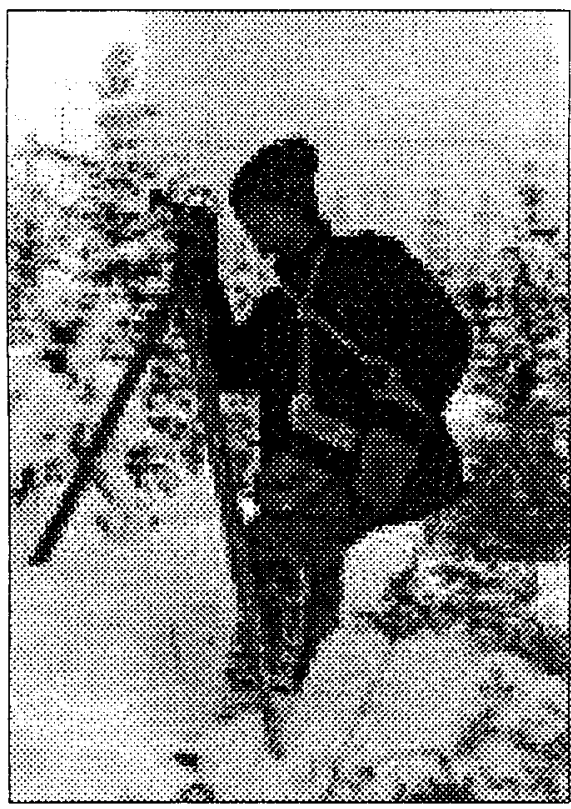

British Columbia Archives I-33576, F.C. Swannell

PLATE 5. Frank Swannell

surveying in Nechako Valley,

1910

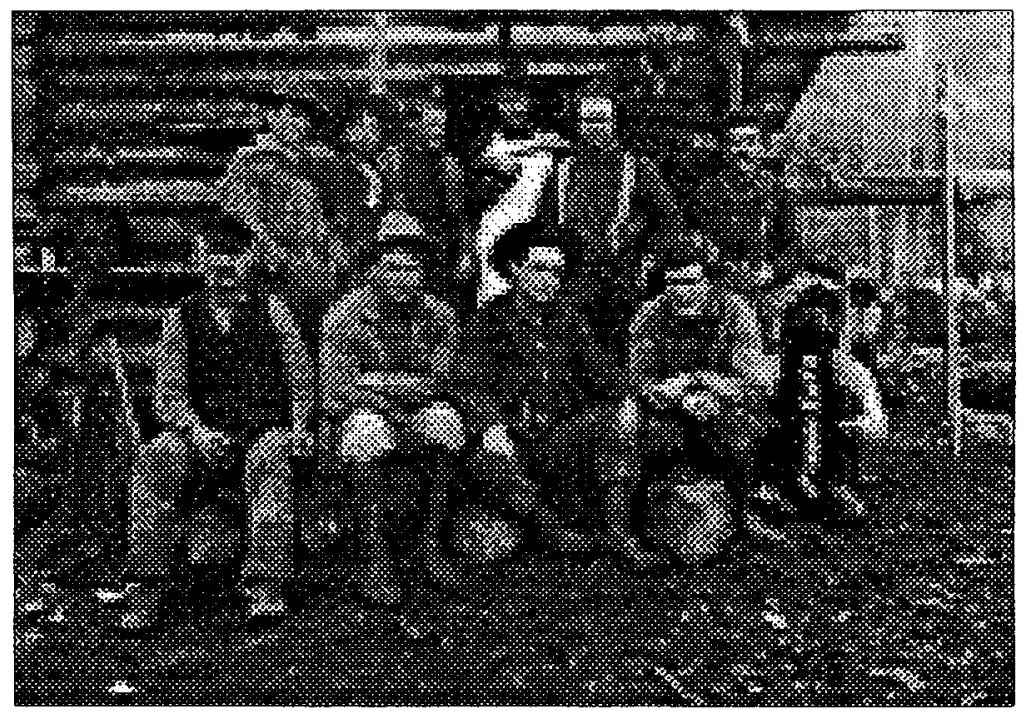

British Columbia Archives 1-58451, F.C. Swannell

Plate 6. Group photograph of Swannell survey party at

Fraser Lake, 1908 
Maps, Illustrations / 147

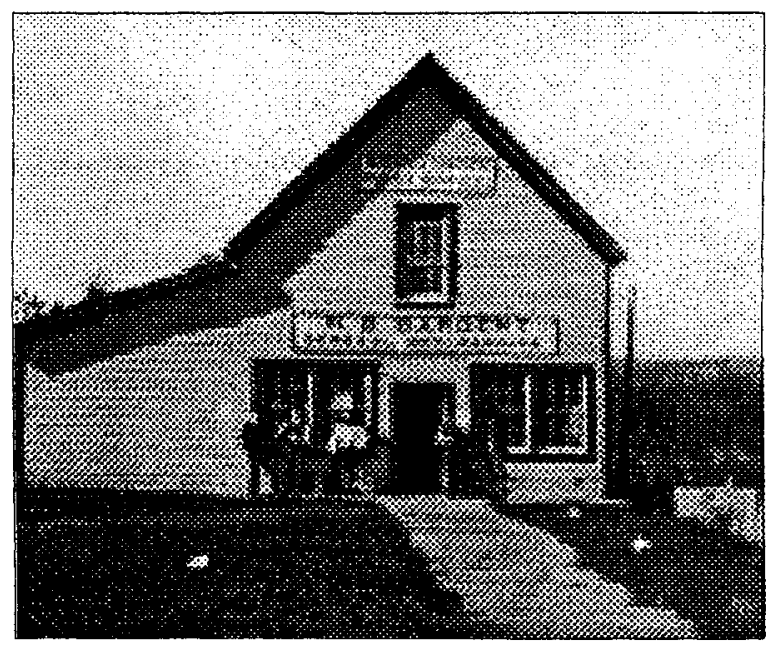

British Columbia Archives E-06566, ca. 1890

Plate 7. Hazelton, R.S. Sargent store and post office

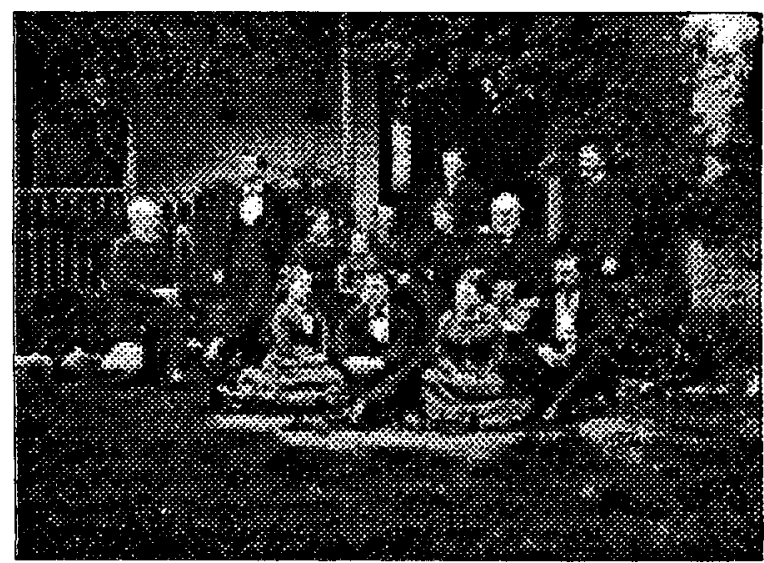

British Columbia Archives G-04990

Plate 8. Dr. William Fraser Tolmie and family. 
Maps, Illustrations / 148

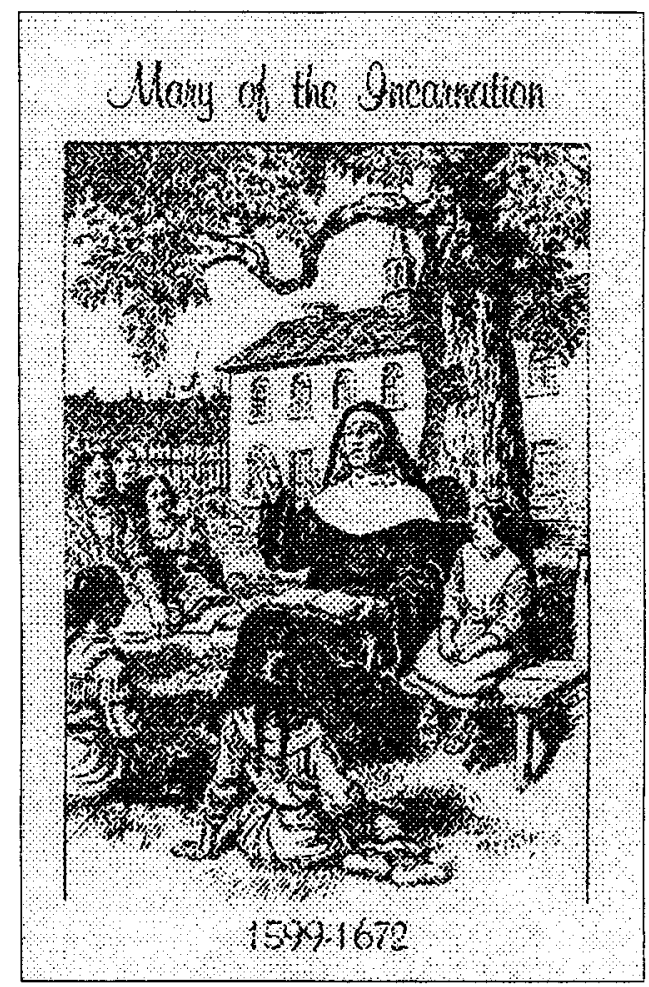

Centre Marie De l'Incarnation

Plate 9. Mary of the Incarnation

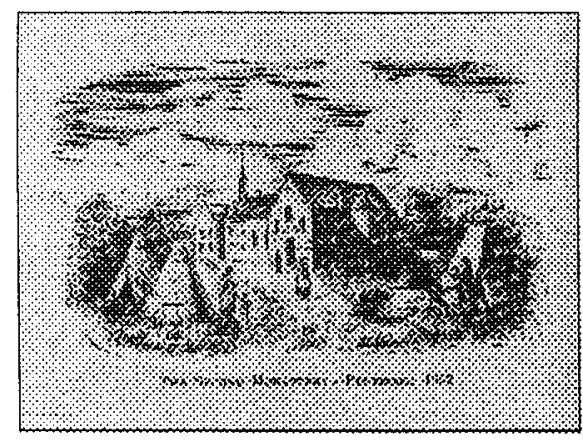

An Ursuline of Quebec 1939: 77

Plate 10. The Second Ursuline Order Monastery, Quebec.

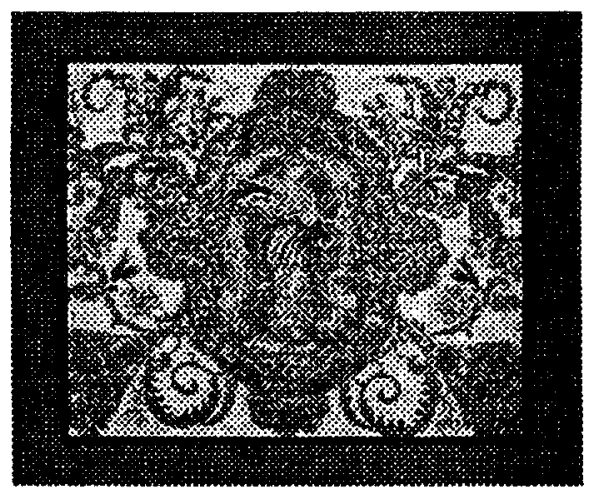

Vues D'ici: 199

PLATE 11. Immaculate

Conception. Central medallion embroidered with pure gold, silver and silk thread, by the Ursulines of Quebec XVIIth C. 


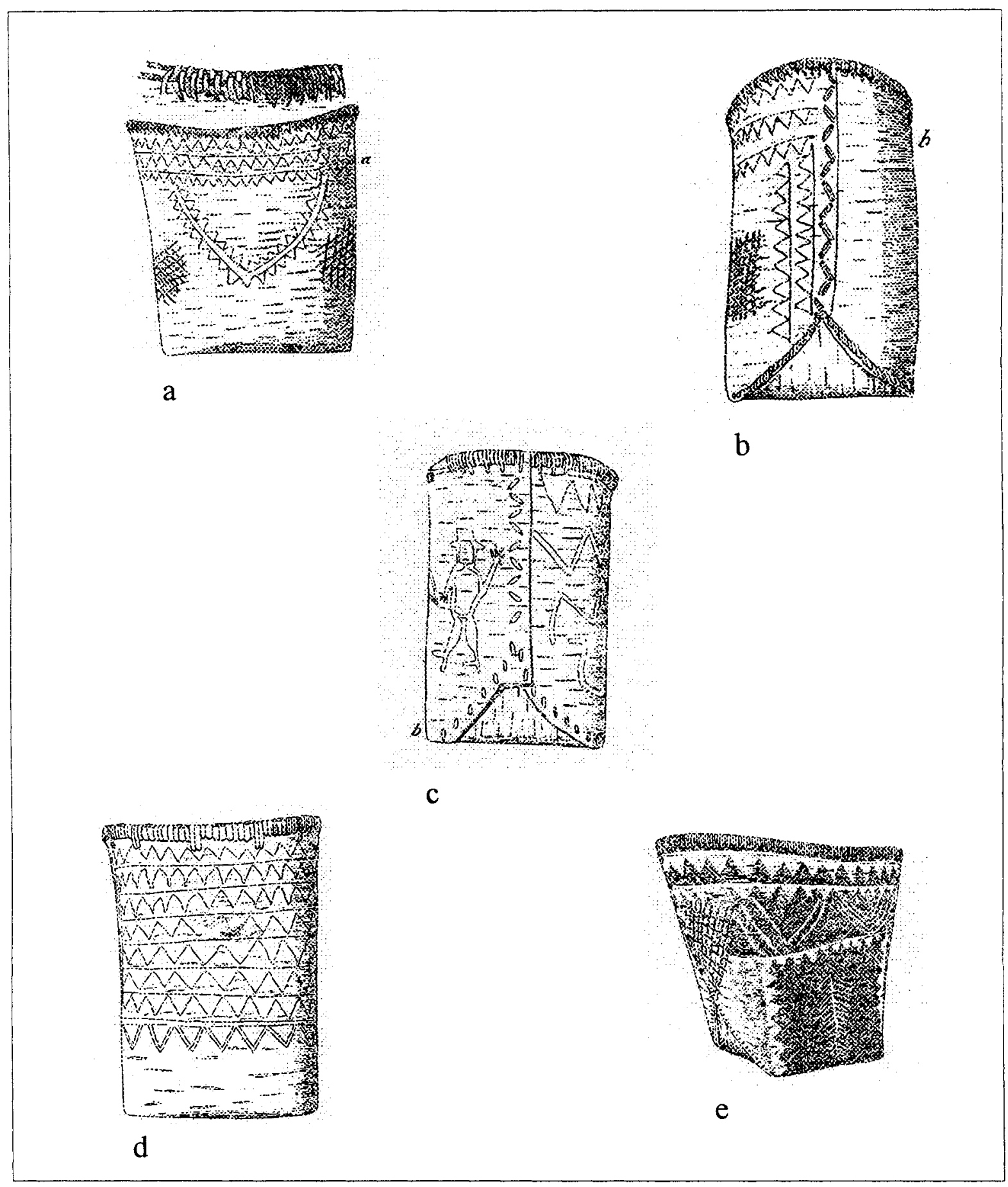

Teit 1905: 478-81

PLATE 12. Examples of end stitching and incised designs on wall fields of baskets: (a) Fig. 202, front and rim. (b) Fig. 202b, short side. (c) Fig. 203b, short side. (d) Figure 204, birch bark basket. (e) Fig. 205, birch bark basket. 


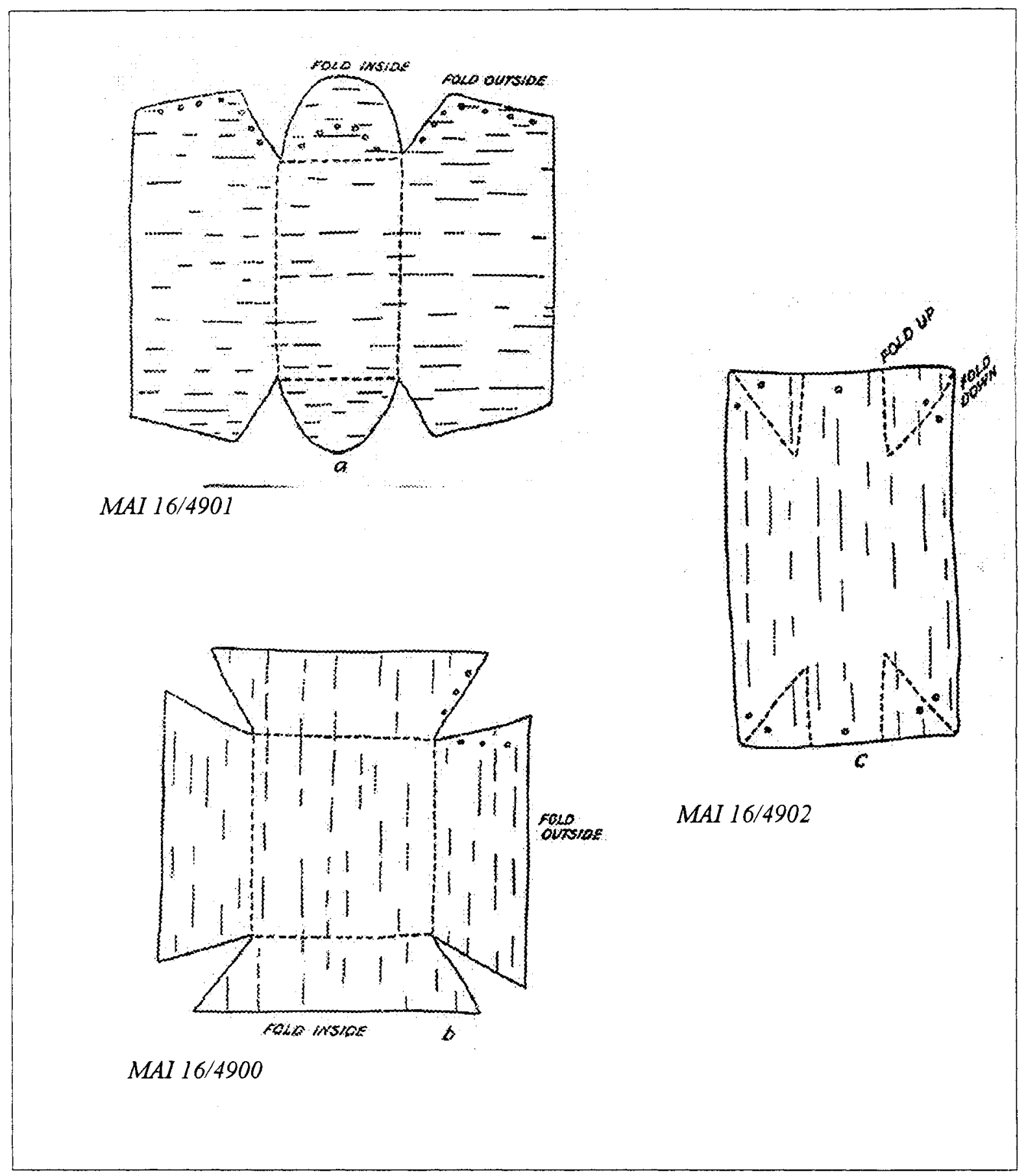

Speck ca. 1941: 238

PLATE 13. (a) Pattern for bark pail and container for berries and women's work materials.

(b) Pattern for dish. (c) Pattern for seamless pail or boiler. 
Maps, Illustrations / 151

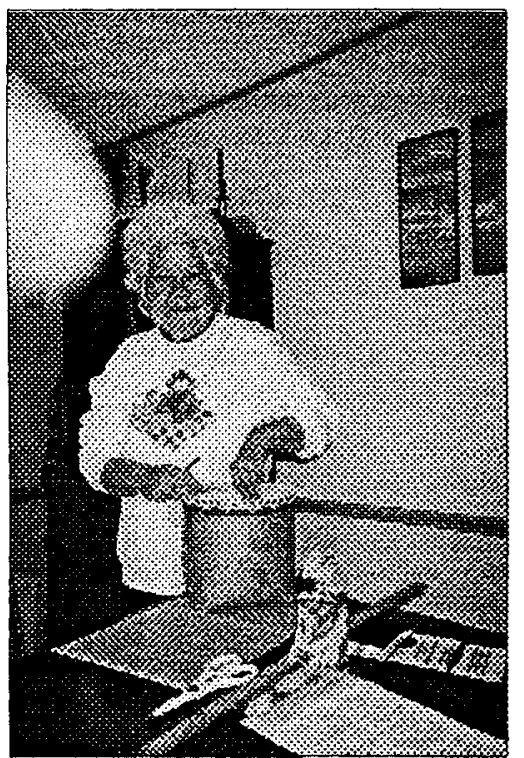

Photograph of O. Thornburn

PLATE 14. Neskolinth

Secwepemc Mary Thomas giving birch bark basketry demonstration, 2001.

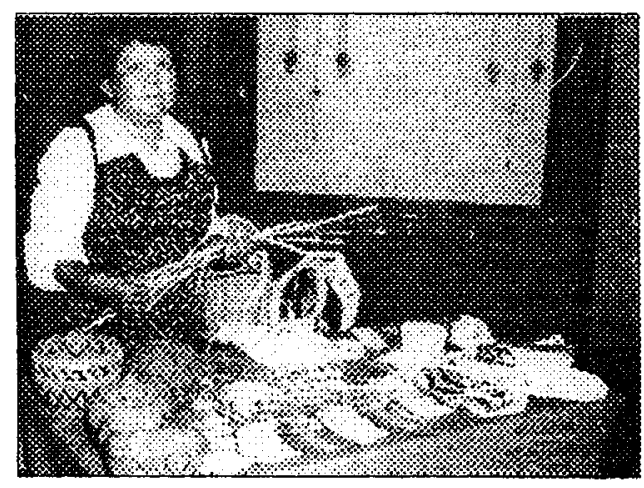

Courtesy of Kelowna Museum

PLATE 17. Neskolinth Secwepemc

Mary Thomas, Early Years

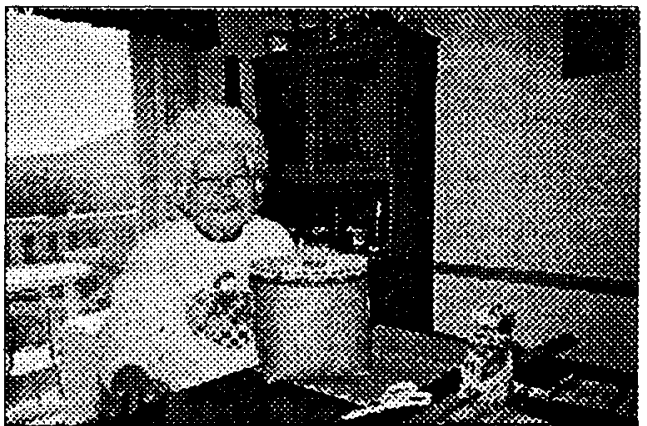

Photograph of $O$. Thornburn

PLATE 15. Neskolinth Secwepemc

Mary Thomas, 2001

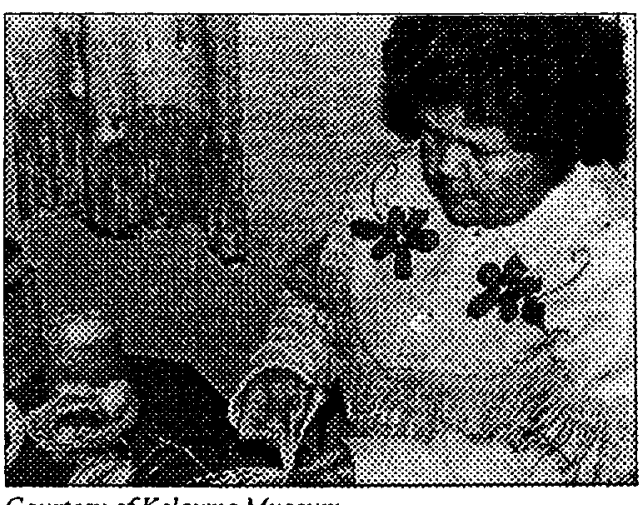

Courtesy of Kelowna Museum

PLATE 16. Neskolinth Secwepemc

Mary Thomas, Middle Years

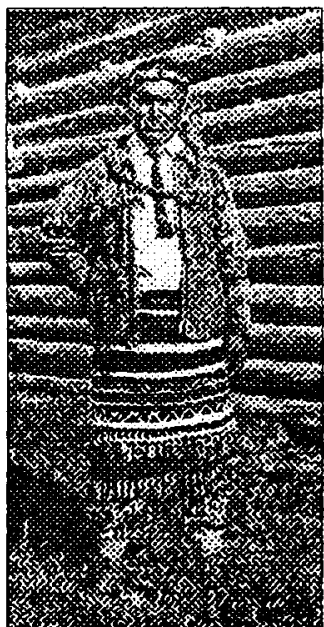

CMC 70386, H.I. Smith 1927.

PLATE 18. Round

Lake Tommy, a

Hagwilget Indian

(Jenness

1943:577-580). 
Maps, Illustrations / 152

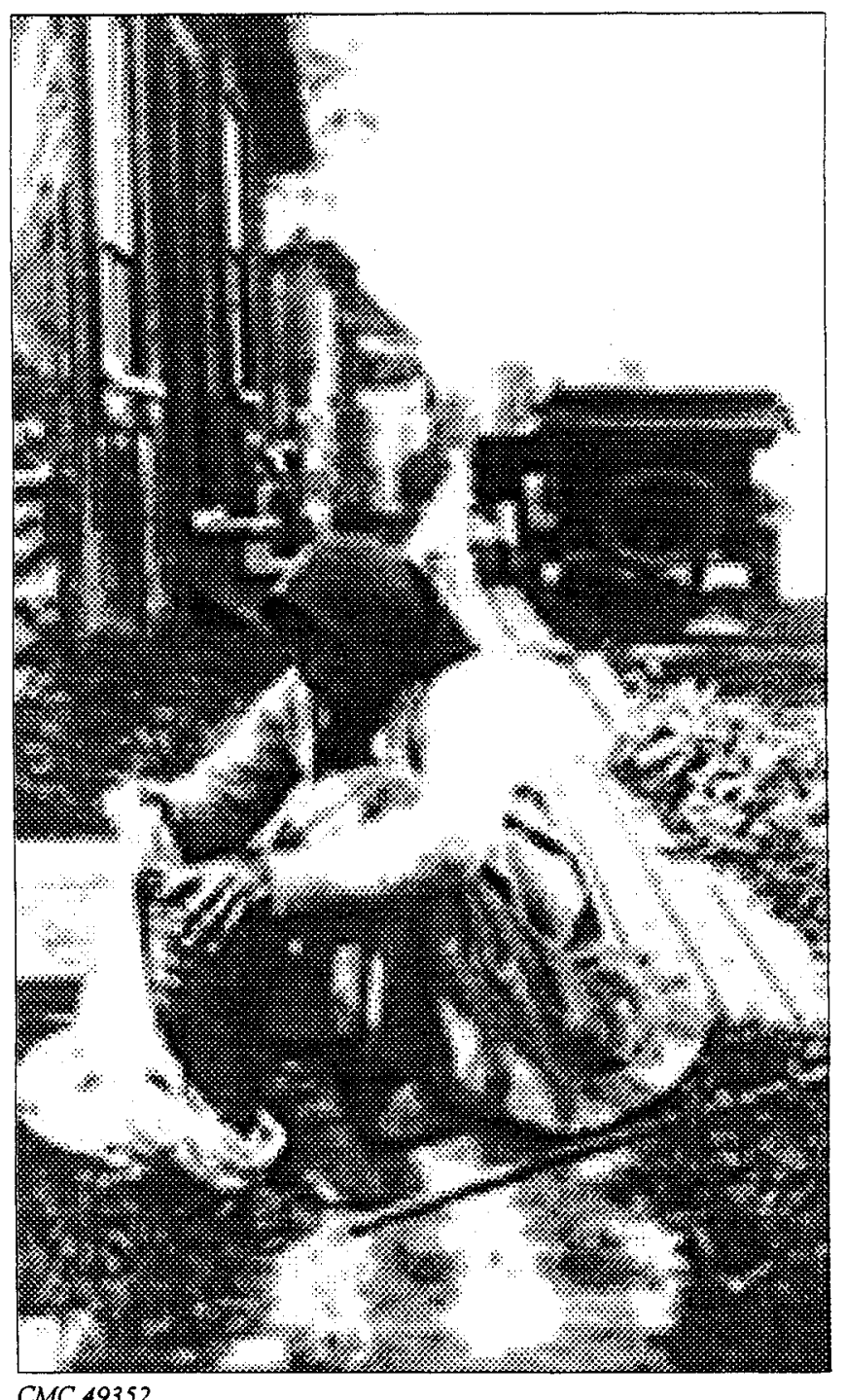

Plate 19. Carrier Wet'suwet'en Adele, Hagwilget ca.1920-21. 
Maps, Illustrations / 153

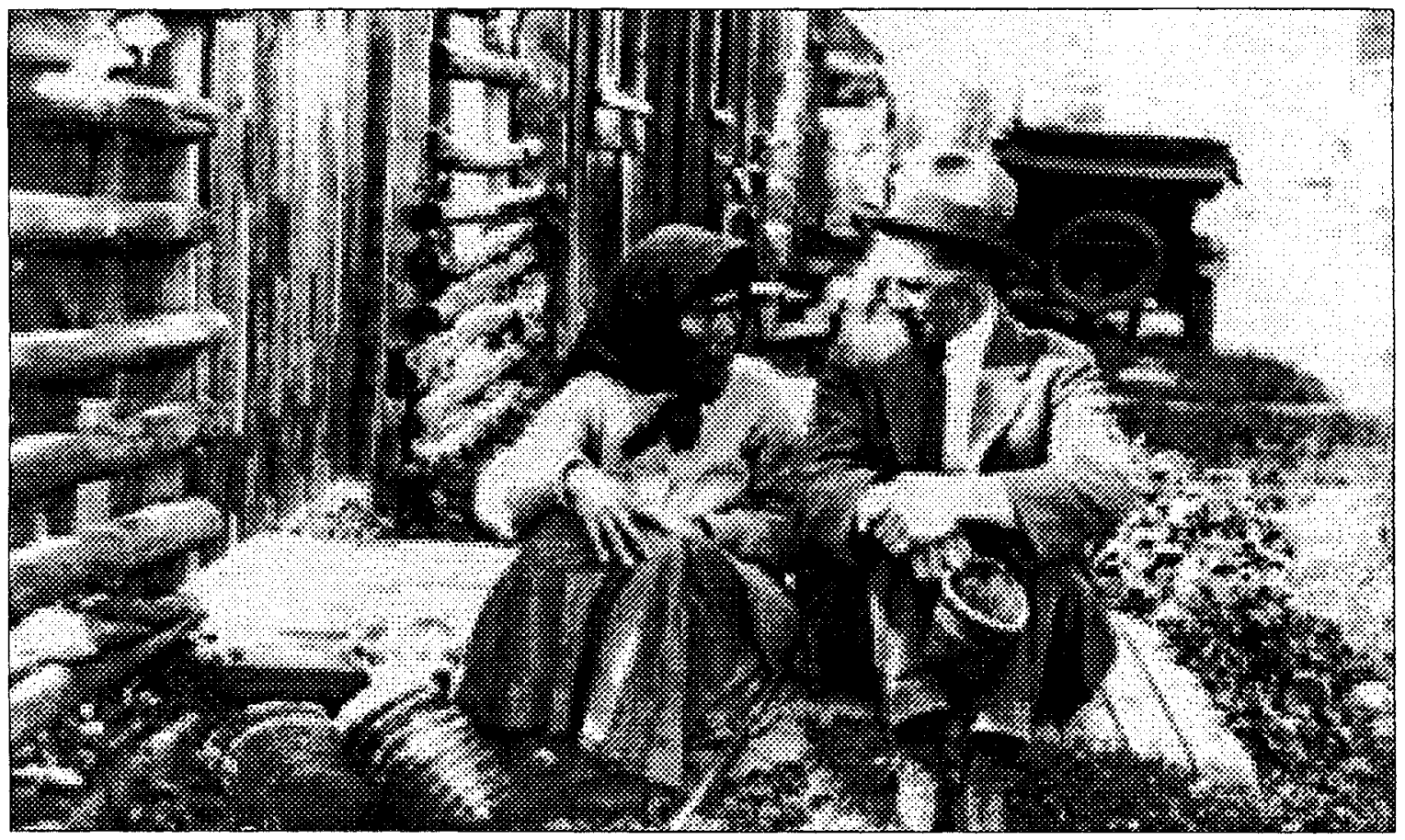

CMC 49613

Plate 20. Carrier Wet'suwet'en Adele, and, Merchant, R.S. Sargent, Hazelton, ca.1920-

21. 


\section{Appendix Three \\ CATALOGUE OF CARRIER AND \\ ALGONQUIN/MONTAGNAIS BASKETRY}

Catalogue / 154 


\section{Carrier Birch Bark Baskets}

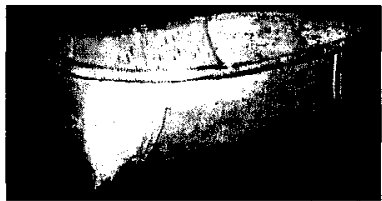

CMC VI B 61

Carrier

Stuart Lake

Rev. A.G. Morice

1892

L. $40 \mathrm{~cm}, W .32 \mathrm{~cm}$

$\mathrm{H} .13 \mathrm{~cm}$.

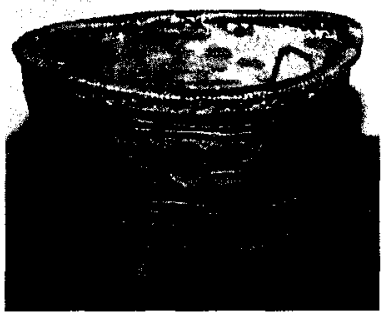

CMC VI B 62

Wet'suwet'en

Hazelton

C.M. Barbeau

1920-21

L. $15.7 \mathrm{~cm}, W .12 .5 \mathrm{~cm}$,

$\mathrm{H} .12 .5 \mathrm{~cm}$

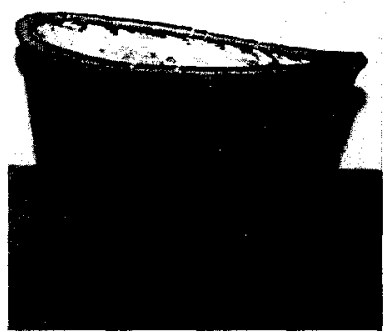

CMC VI B 65

Wet'suwet'en

Hazelton

C.M. Barbeau

1920-21

L. $26.7 \mathrm{~cm}, W .20 .7 \mathrm{~cm}$

H. $20.5 \mathrm{~cm}$

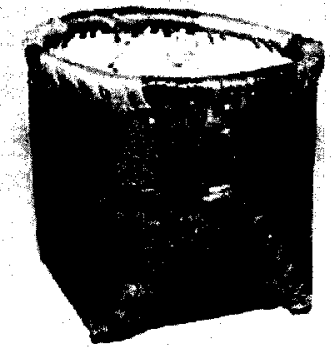

CMC VI B 68

Wet'suwet'en

Kisgagas, Hagwelgate [sic]

C.M. Barbeau

1920-21

L. $20.5 \mathrm{~cm}, W .18 .8 \mathrm{~cm}$

H. $18 \mathrm{~cm}$

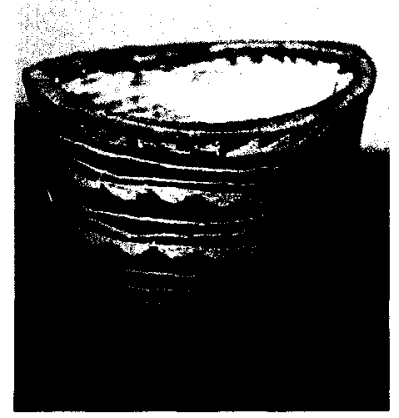

CMC VI B 63

Wet'suwet'en

Hazelton

C.M.Barbeau

1920-21

L. $15.5 \mathrm{~cm}, W .12 .5 \mathrm{~cm}$,

H. $13.5 \mathrm{~cm}$.

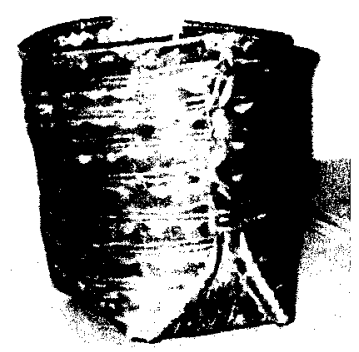

CMC VI B 66

Wet'suwet'en

Hazelton

C.M. Barbeau

1920-21

L. $21.5 \mathrm{~cm}, \mathrm{~W} .18 .5 \mathrm{~cm}$

$H .21 .5 \mathrm{~cm}$.

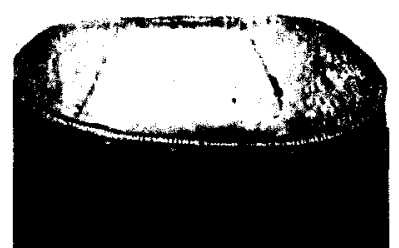

CMC VI B 69

Carrier

C.M. Barbeau

1920-21

L. $45 \mathrm{~cm}, W .45 \mathrm{~cm}$,

$\mathrm{H} .20 \mathrm{~cm}$.

L. $18.5 \mathrm{~cm}, W .16 \mathrm{~cm}$

H. $15.5 \mathrm{~cm}$ 


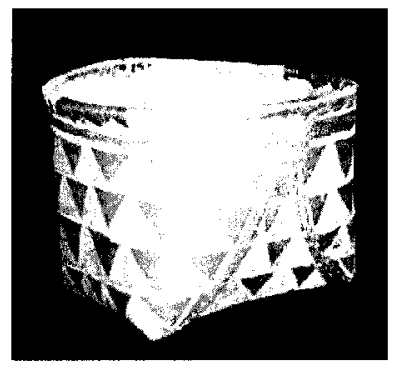

CMC VI B 70

Carrier

Fort Fraser

D. Jenness

1924.

L. $23 \mathrm{~cm}, W .21 .5 \mathrm{~cm}$,

H. $16.5 \mathrm{~cm}$

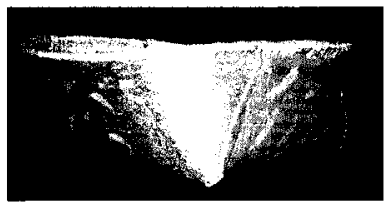

CMC VI B 73

Wet'suwet'en

Hazelton

H.I. Smith

1925

$\mathrm{L} .41 \mathrm{~cm}, W .42 \mathrm{~cm}$,

H. $14.5 \mathrm{~cm}$.

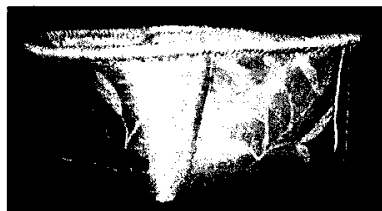

CMC VI B 75, view 2

Wet'suwet'en

Hazelton

H.I. Smith

1925

L. $36.5 \mathrm{~cm}, W .32 .5 \mathrm{~cm}$,

H. $16 \mathrm{~cm}$.

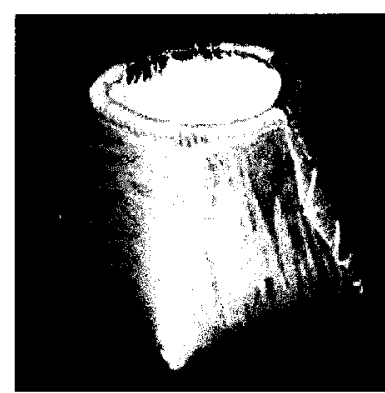

CMC VI B 71

Carrier

Fort Fraser

D. Jenness

1924

L. $14.6 \mathrm{~cm}, W .13 \mathrm{~cm}$,

H. $12 \mathrm{~cm}$.

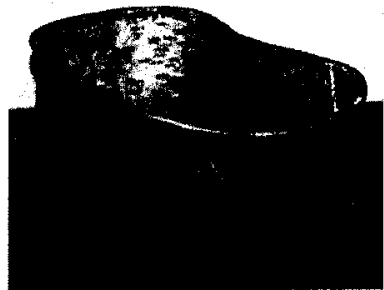

CMC VI B 72

Wet'suwet'en

Hazelton

H.I. Smith

1925

L. $46 \mathrm{~cm}, W .26 \mathrm{~cm}$

H. $17.5 \mathrm{~cm}$.

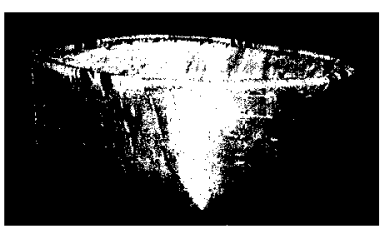

CMC VI B 74

Wet'suwet'en

Hazelton

H.I. Smith

1925

$\mathrm{L} .41 \mathrm{~cm}, W .39 \mathrm{~cm}$,

H. $16 \mathrm{~cm}$.

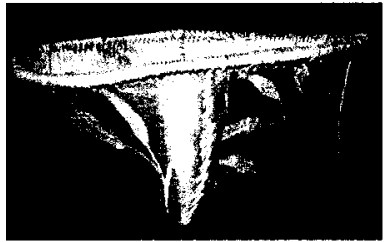

CMC VI B 75, view 1

Wet'suwet'en

Hazelton

H.I. Smith

1925

L. $36.5 \mathrm{~cm}, W .32 .5 \mathrm{~cm}$,

H. $16 \mathrm{~cm}$.

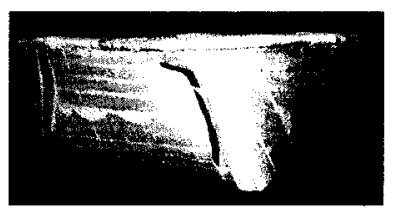

CMC VI B 76

Wet'suwet'en

Hazelton

H.I. Smith

1925

L. $40 \mathrm{~cm}, W .37 .5 \mathrm{~cm}$,

H. $16 \mathrm{~cm}$

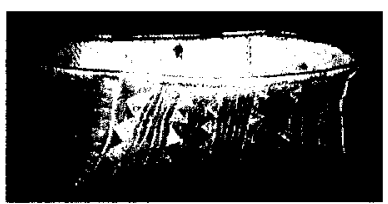

CMC VI 877

Wet'suwet'en

Hazelton

H.I. Smith

1925

L. $43 \mathrm{~cm}, W .40 \mathrm{~cm}$,

H. $14.5 \mathrm{~cm}$ 


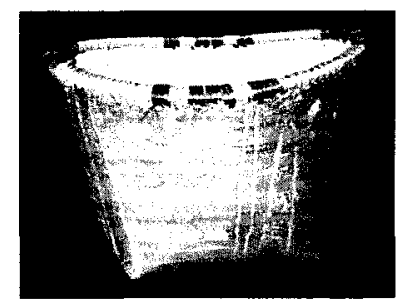

CMC VI B 78, view 1

Wet'suwet'en

Hazelton

H.I. Smith

1925

L. $22.7 \mathrm{~cm}, W .18 .2 \mathrm{~cm}$

H. $18 \mathrm{~cm}$.

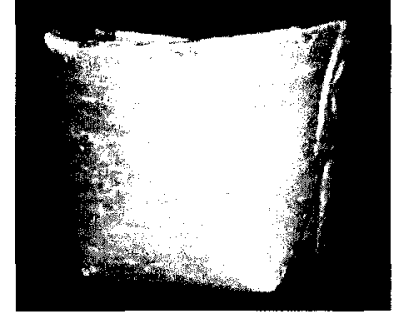

CMC VI B 79, view 2

Wet'suwet'en

Hazelton

H.I. Smith

1925

L. $20.3 \mathrm{~cm}, W .16 .7 \mathrm{~cm}$,

$\mathrm{H} .17 \mathrm{~cm}$.

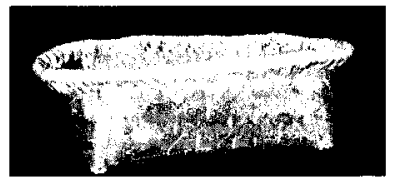

CMC VI B 82

Wet'suwet'en

Hazelton

H.I. Smith

1925

L. $23.5 \mathrm{~cm}, W .22 \mathrm{~cm}$,

H. $7 \mathrm{~cm}$.

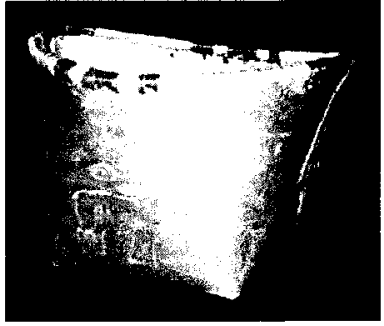

CMC VI B 78, view 2

Wet'suwet'en Hazelton H.I. Smith

1925

L. $22.7 \mathrm{~cm}, W .18 .2 \mathrm{~cm}$

H. $18 \mathrm{~cm}$.

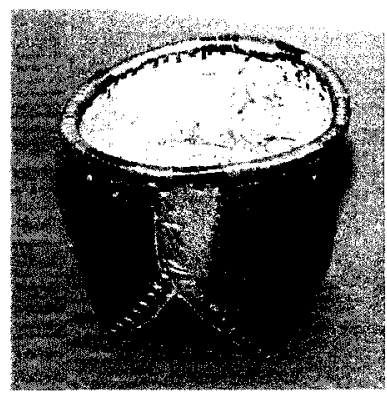

CMC VI B 80

Wet'suwet'en

Hazelton

H.I. Smith

1925

L. $15.5 \mathrm{~cm} . W .14 \mathrm{~cm}$,

H. $13 \mathrm{~cm}$.

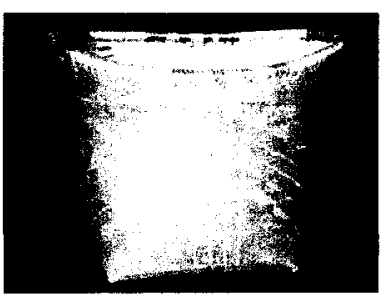

CMC VI B 79, view 1

Wet'suwet'en

Hazelton

H.I Smith

1925

L. $20.3 \mathrm{~cm}, W .16 .7 \mathrm{~cm}$,

$\mathrm{H} .17 \mathrm{~cm}$

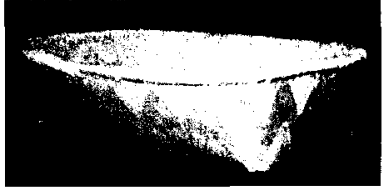

CMC VI B 81

Wet'suwt'en

Hazelton

H.I. Smith

1925

L. $25.5 \mathrm{~cm}, W .21 .8 \mathrm{~cm}$.

$\mathrm{H} .7 \mathrm{~cm}$.

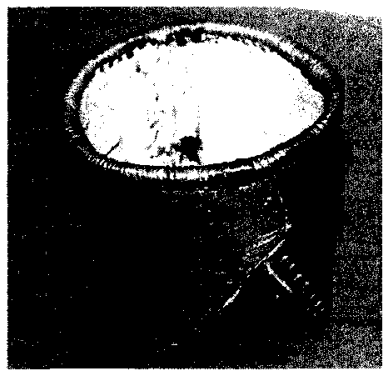

CMC VI B 83

Wet'suwet'en

Hazelton

H.I. Smith

1925

L. $14.5 \mathrm{~cm}, W .13 \mathrm{~cm}$.,

$\mathrm{H} .12 \mathrm{~cm}$

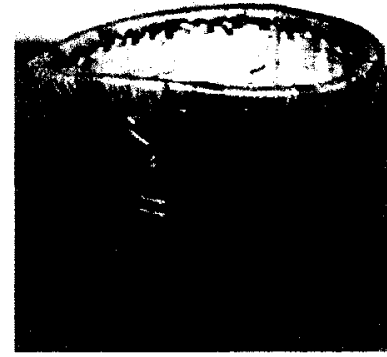

CMC VI B 84

Wet'suwet'en

Hazelton

H.I. Smith

1925

L. $15 \mathrm{~cm}, W .14 \mathrm{~cm}$,

H. $10.5 \mathrm{~cm}$. 


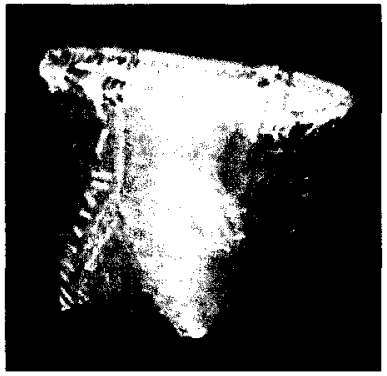

CMC VI B 85

Wet'suwet'en

Hazelton

H.I. Smith

1925

L. $16 \mathrm{~cm}, W .14 .5 \mathrm{~cm}$,

H. $13 \mathrm{~cm}$.

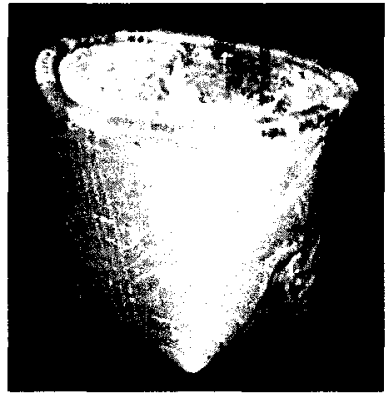

CMC VI B 87, view 2

Wet'suwet'en

Hazelton

H.I. Smith

1925

L. $19 \mathrm{~cm}, W .14 .7 \mathrm{~cm}$,

H. $16 \mathrm{~cm}$.

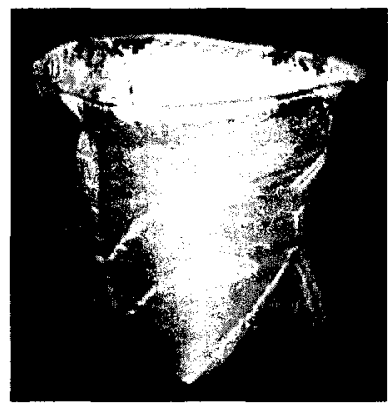

CMC VI B 90

Wet'suwet'en

Hazelton

H.I. Smith

1925

L. $18.2 \mathrm{~cm}, W .16 \mathrm{~cm}$,

$\mathrm{H} .16 .5 \mathrm{~cm}$.

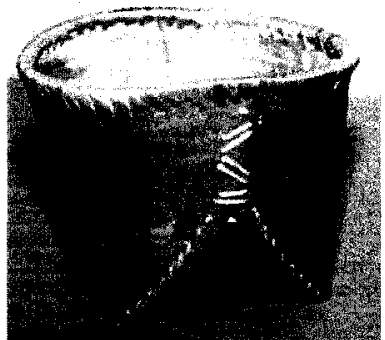

CMC VI B 86

Wet'suwet'en

Hazelton

H.I. Smith

1925

L. $18.5 \mathrm{~cm}, W .15 \mathrm{~cm}$

$\mathrm{H} .14 \mathrm{~cm}$.

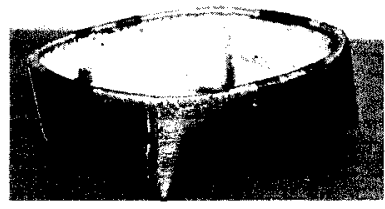

CMC VI B 88

Wet'suwet'en

Hazelton

H.I. Smith

1925

L. $25 \mathrm{~cm}, W .24 .5 \mathrm{~cm}$,

H. $8.7 \mathrm{~cm}$.

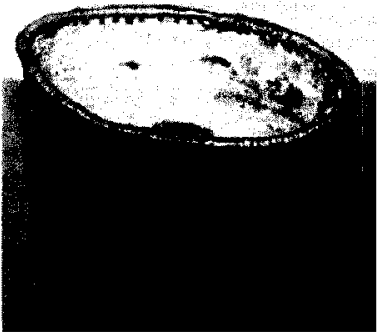

CMC VI B 91

Wet'suwet'en

Hazelton

H.I. Smith

1925

L. $18 \mathrm{~cm}, W .15 .5 \mathrm{~cm}$,

H. $13.5 \mathrm{~cm}$

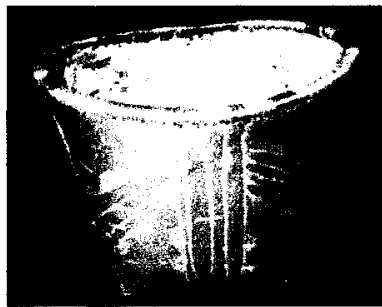

CMC VI B 87, view 1

Wet'suwet'en

Hazelton

H.I. Smith

1925

L. $19 \mathrm{~cm}, W .14 .7 \mathrm{~cm}$,

H. $16 \mathrm{~cm}$.

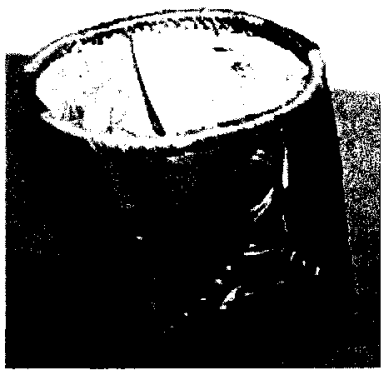

CMC VI B 89

Wet'suwet'en

Hazelton

H.I. Smith

1925

L. $21.2 \mathrm{~cm}, W .17 .7 \mathrm{~cm}$,

H. $16.5 \mathrm{~cm}$.

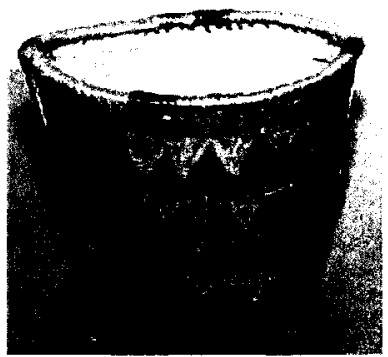

CMC VI B 92

Wet'suwet'en

Hazelton

H.I. Smith

1925

L. $16 \mathrm{~cm}, W .15 .2 \mathrm{~cm}$,

H. $15 \mathrm{~cm}$. 


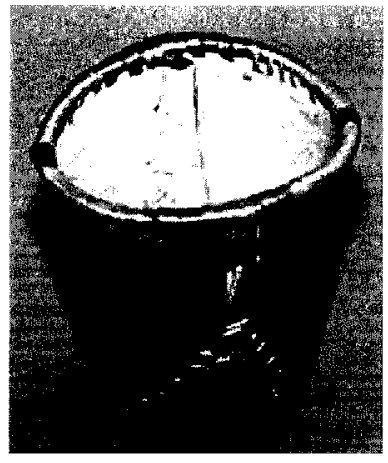

CMC VI B 93

Wet'suwet'en

Hazelton

H.I. Smith

1925

L. $13.5 \mathrm{~cm}, W .12 \mathrm{~cm}$,

H. $11.5 \mathrm{~cm}$.

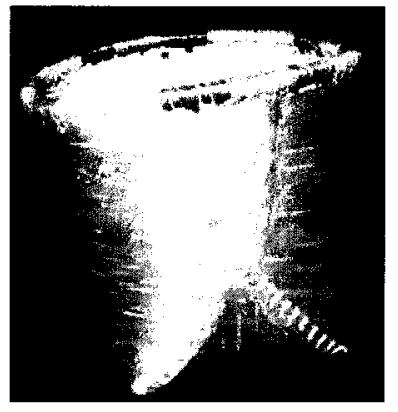

CMC VI B 96

Wet'suwet'en

Hazelton

H.I. Smith

1925

L. $20 \mathrm{~cm}, W .17 \mathrm{~cm}$,

$\mathrm{H} .17 \mathrm{~cm}$

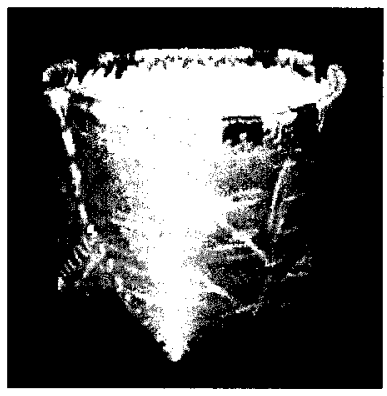

CMC VI B 99

Wet'suwet'en

Hazelton

H.I. Smith

1925

L. $14.5 \mathrm{~cm}, W .13 \mathrm{~cm}$,

$\mathrm{H} .11 .5 \mathrm{~cm}$

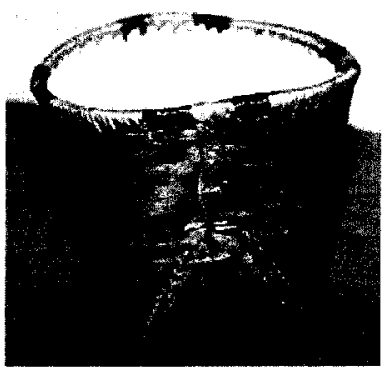

CMC VI B 94

Wet'suwet'en

Hazelton

H.I. Smith

1925

L. $21 \mathrm{~cm}, W .18 \mathrm{~cm}$

$\mathrm{H} .17 \mathrm{~cm}$.

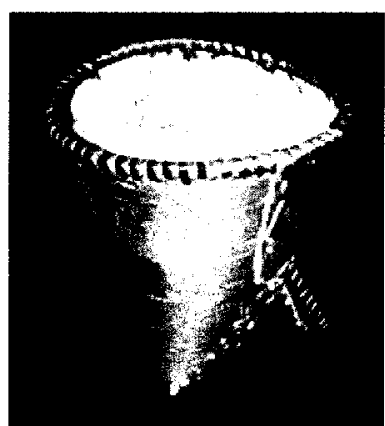

CMC VI B 97

Wet'suwet'en

Hazelton

H.I. Smith

1925

L. $16.5 \mathrm{~cm}, W .14 \mathrm{~cm}$,

H. $14.5 \mathrm{~cm}$

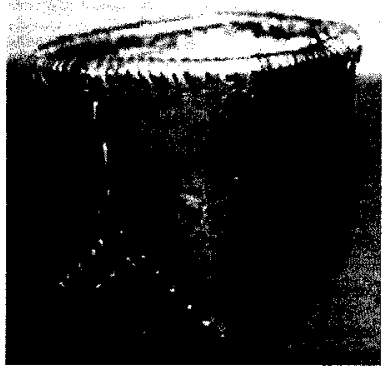

VI B 100

Wet'suwet'en

Hazelton

H.I. Smith

1925

L. $12.5 \mathrm{~cm}, W .10 .8 \mathrm{~cm}$,

H. $10 \mathrm{~cm}$.

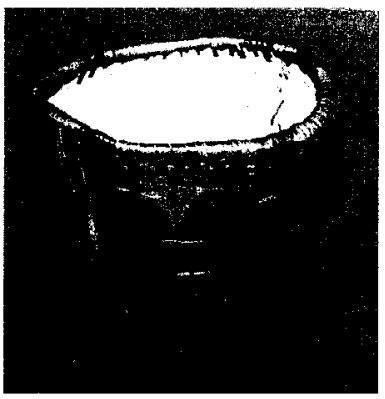

CMC VI B 95

Wet'suwet'en

Hazelton

H.I. Smith

1925

L. $12.5 \mathrm{~cm}, W .11 \mathrm{~cm}$,

$\mathrm{H} .11 \mathrm{~cm}$.

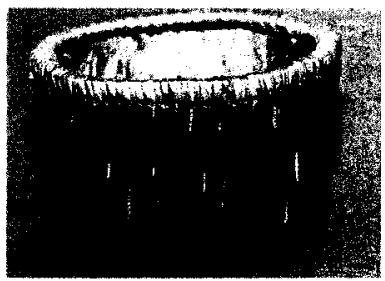

CMC VI B 98

Wet'suwet'en

Hazelton

H.I. Smith

1925

L. $13 \mathrm{~cm}, W .11 .7 \mathrm{~cm}$

$\mathrm{H} .8 \mathrm{~cm}$.

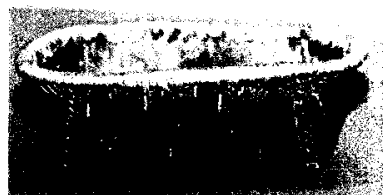

CMC VI B 101

Wet'suwet'en

Hazelton

H.I. Smith

1925

L. $20.8 \mathrm{~cm}, W .16 \mathrm{~cm}$

H. $6.5 \mathrm{~cm}$ 


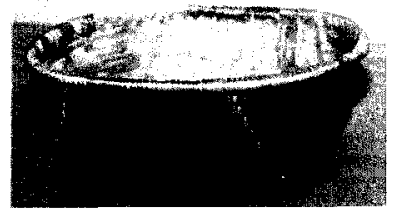

CMC VI B 102

Wet'suwet'en

Hazelton

H.I. Smith

1925

L. $24 \mathrm{~cm}, W .20 .5 \mathrm{~cm}$,

$H .9 \mathrm{~cm}$.

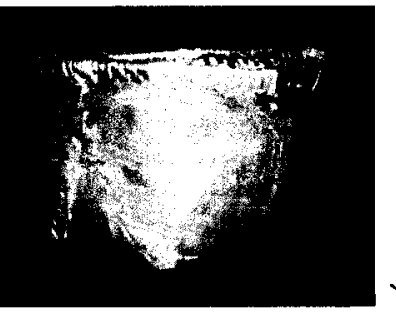

CMC VI B 105

Wet'suwet'en

Hazelton

H.I. Smith

1925

L. $13.2 \mathrm{~cm}, W .13 .2 \mathrm{~cm}$,

H. $10.5 \mathrm{~cm}$

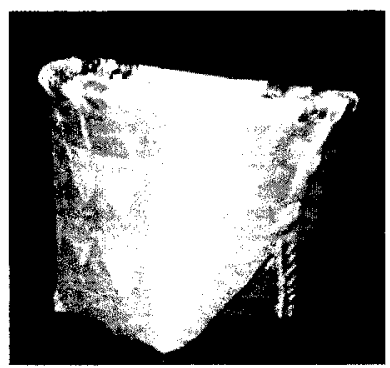

CMC VI B 108

Wet'suwet'en

Hazelton

H.I. Smith

1925

L. $14.5 \mathrm{~cm}, W .13 \mathrm{~cm}$,

H. $12.5 \mathrm{~cm}$.

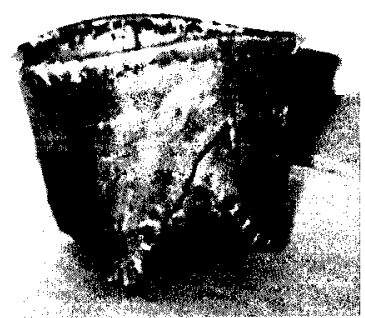

CMC VI B 103

Wet'suwet'en

Hazelton

H.I. Smith

1925

L. $16 \mathrm{~cm}, W .14 \mathrm{~cm}$

H. $12.5 \mathrm{~cm}$

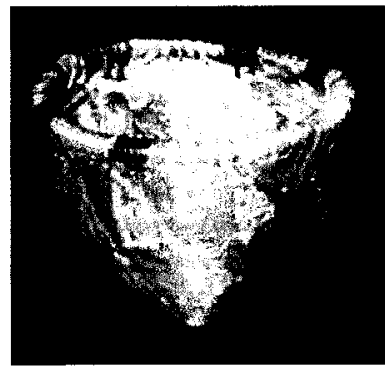

CMC VI B 106

Wet'suwet'en

Hazelton

H.I. Smith

1925

L. $11.2 \mathrm{~cm}, W .10 .2 \mathrm{~cm}$

H. $7.5 \mathrm{~cm}$.

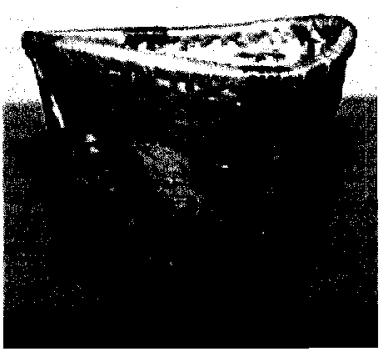

CMC VI B 109

Wet'suwet'en

Hazelton

H.I. Smith

1925

L. $14 \mathrm{~cm}, W .12 .5 \mathrm{~cm}$,

$\mathrm{H} .13 \mathrm{~cm}$.

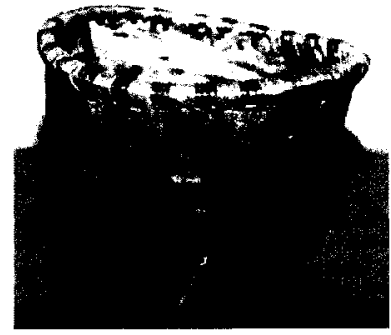

CMC VI B 104

Wet'suwet'en

Hazelton

H.I. Smith

1925

L. $16 \mathrm{~cm}, W .14 \mathrm{~cm}$,

H. $12.5 \mathrm{~cm}$.

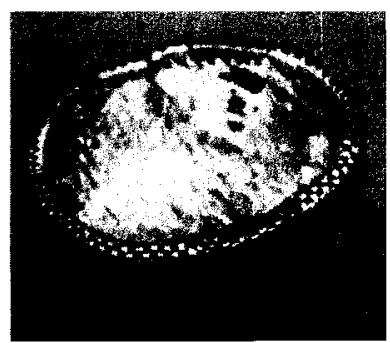

CMC VI B 107

Wet'suwet'en

Hazelton

H.I. Smith

1925

L. $11.7 \mathrm{~cm}, W .12 .5 \mathrm{~cm}$,

H. $5 \mathrm{~cm}$.

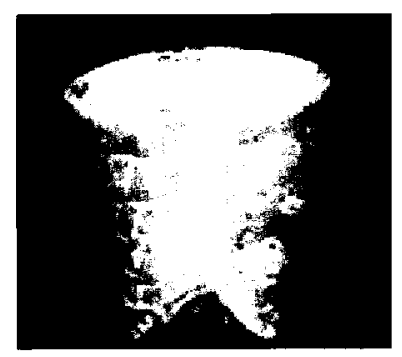

CMC VI B 110

Wet'suwet'en

Hazelton

H.I. Smith

1925

L. $14 \mathrm{~cm}, W .13 .2 \mathrm{~cm}$,

H. $14.5 \mathrm{~cm}$. 


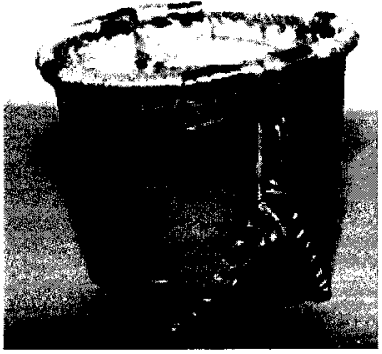

CMC VI B 111

Wet'suwet'en

Hazelton

H.I. Smith

1925

L. $13.5 \mathrm{~cm}, W .12 \mathrm{~cm}$,

H. $12 \mathrm{~cm}$.

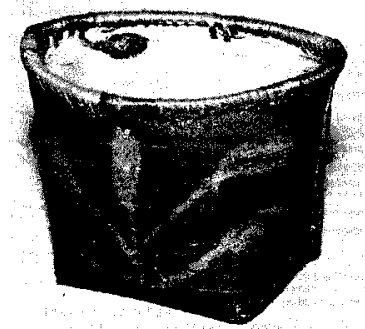

CMC VI B 114, view 1

Wet'suwet'en

Hazelton

H.I. Smith

1925

L. $14.5 \mathrm{~cm}, W .12 .5 \mathrm{~cm}$,

H. $12 \mathrm{~cm}$.

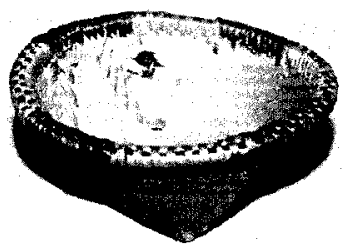

CMC VI B 116

Wet'suwet'en

Hazelton

H.I. Smith

1925

L. $11.5 \mathrm{~cm}, W .11 .5 \mathrm{~cm}$,

$\mathrm{H} .5 \mathrm{~cm}$.

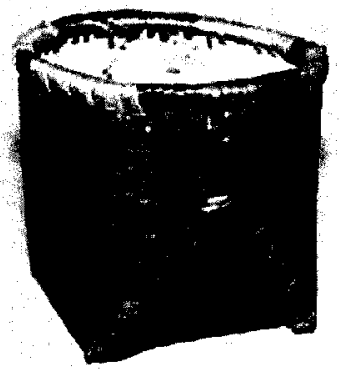

\section{CMC VI B 112}

Wet'suwet'en

Hazelton

H.I. Smith

1925

L. $11 \mathrm{~cm}, W .9 .7 \mathrm{~cm}$,

$H .9 \mathrm{~cm}$.

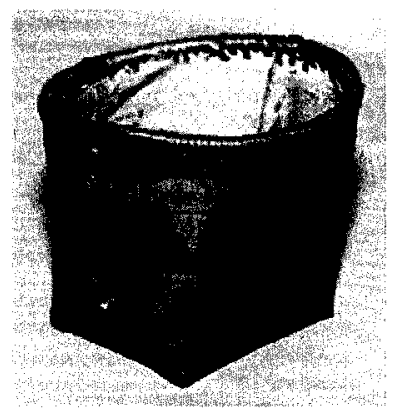

\section{CMC VI B 114, view 2}

Wet'suwet'en

Hazelton

H.I. Smith

1925

L. $14.5 \mathrm{~cm}, W .12 .5 \mathrm{~cm}$,

H. $12 \mathrm{~cm}$.

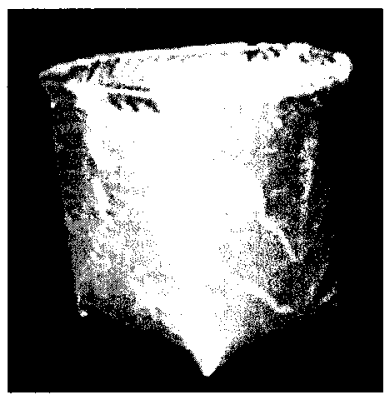

CMC VI B 117

Wet'suwet'en

Hazelton

H.I. Smith

1925

L. $18.5 \mathrm{~cm}, W .15 .5 \mathrm{~cm}$,

H. $16 \mathrm{~cm}$.

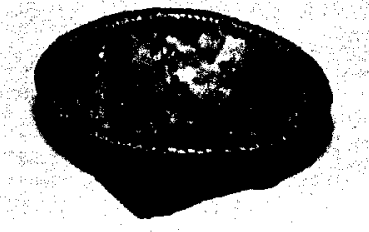

CMC VI B 113

Wet'suwet'en

Hazelton

H.I. Smith

1925

L. $11.5 \mathrm{~cm}, W .11 .5 \mathrm{~cm}$,

H. $4.5 \mathrm{~cm}$.

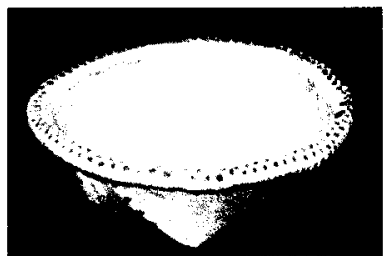

CMC VI B 115

Wet'suwet'en

Hazelton

H.I. Smith

1925

L. $14.5 \mathrm{~cm}, W .15 \mathrm{~cm}$,

H. $6.5 \mathrm{~cm}$.

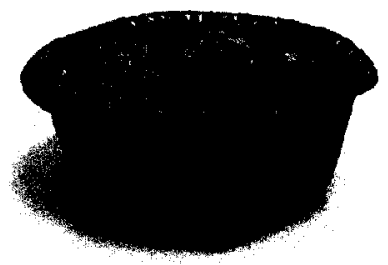

CMC VI B 118

Wet'suwet'en Hazelton

H.I. Smith

1925

L. $12 \mathrm{~cm}, W .12 .5 \mathrm{~cm}$,

$H .5 .5 \mathrm{~cm}$. 


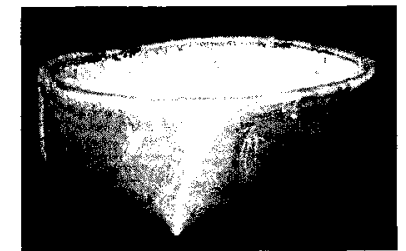

CMC VI B 119

Wet'suwet'en

Hazelton

H.I. Smith

1925

L. $25.7 \mathrm{~cm}, W .25 \mathrm{~cm}$,

H. $10 \mathrm{~cm}$.

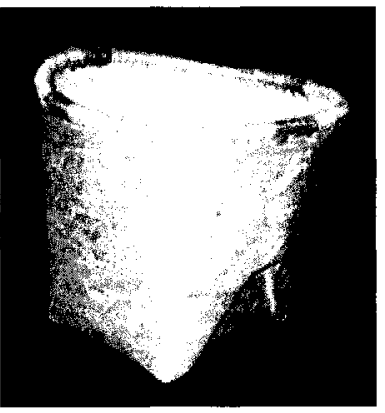

CMC VI B 122

Wet'suwet'en

Hazelton

H.I. Smith

1925

L. $13.5 \mathrm{~cm}, W .12 \mathrm{~cm}$,

$H .9 .5 \mathrm{~cm}$.

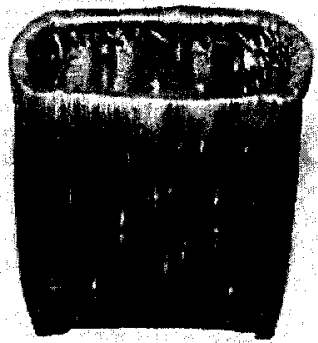

CMC VI B 125

Wet'suwet'en

Hazelton

H.I. Smith

1925

L. $11.5 \mathrm{~cm}, W .9 .5 \mathrm{~cm}$,

$\mathrm{H} .10 \mathrm{~cm}$

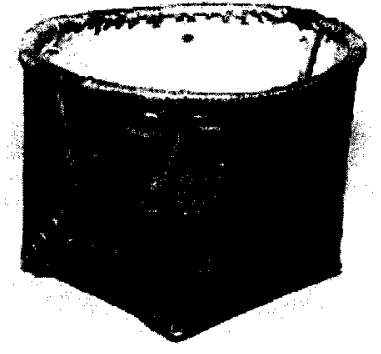

CMC VI B 120

Wet'suwet'en

Hazelton

H.I. Smith

1925

L. $15 \mathrm{~cm}, W .13 .8 \mathrm{~cm}$,

H. $10.5 \mathrm{~cm}$.

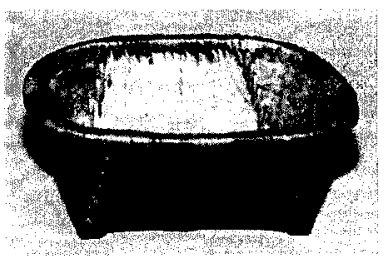

CMC VI B 123

Wet'suwet'en

Hazelton

H.I. Smith

1925

L. $14.5 \mathrm{~cm}, W .15 .2 \mathrm{~cm}$

H. $5.5 \mathrm{~cm}$.

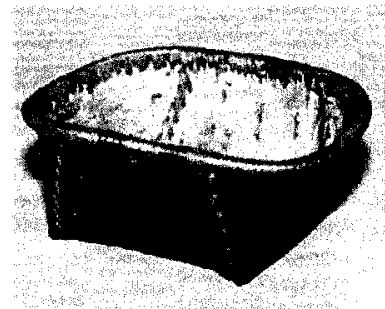

\section{CMC VI B 126}

Wet'suwet'en

Hazelton

H.I. Smith

1925

L. $11.5 \mathrm{~cm}, W .13 .5 \mathrm{~cm}$,

H. $6 \mathrm{~cm}$.

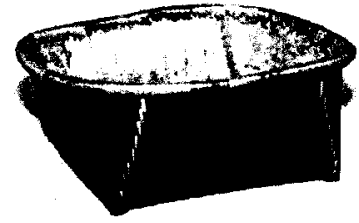

CMC VI B 121

Wet'suwet'en

Hazelton

H.I. Smith

1925

L. $21.3 \mathrm{~cm}, W .17 \mathrm{~cm}$,

$\mathrm{H} .8 \mathrm{~cm}$.

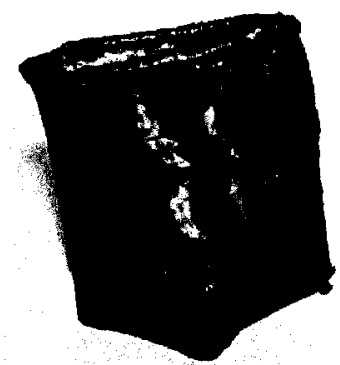

CMC VI B 124

Wet'suwet'en

Hazelton

H.I. Smith

1925

L. $15.5 \mathrm{~cm}, W .14 .5 \mathrm{~cm}$,

H. $15.5 \mathrm{~cm}$.

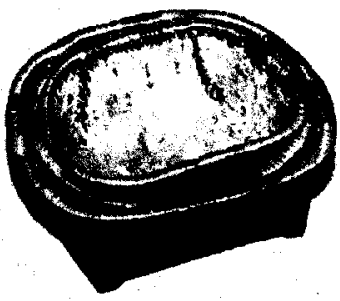

CMC VI B 126, 127, and

128 nested

Wet'suwet'en

Hazelton

H.I. Smith

1925 


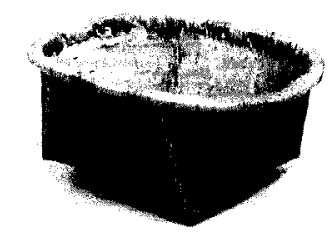

CMC VI B 127

Wet'suwet'en

Hazelton

H.I. Smith

1925

L. $14 \mathrm{~cm}, W .15 \mathrm{~cm}$,

H. $7 \mathrm{~cm}$.

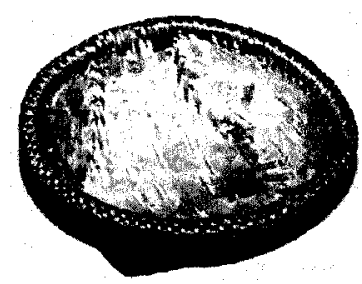

CMC VI B 131

Wet'suwet'en

Hazelton

H.I. Smith

1925

L. $13 \mathrm{~cm}, W .12 \mathrm{~cm}$,

H. $5.5 \mathrm{~cm}$

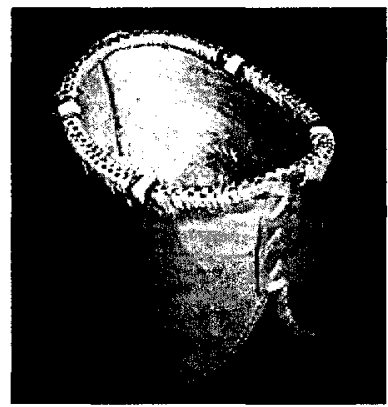

CMC VI B 134

Ulkatcho

Bella Coola

H.I. Smith

1922

L. $17.5 \mathrm{~cm}, W .12 .2 \mathrm{~cm}$,

H. $15 \mathrm{~cm}$.

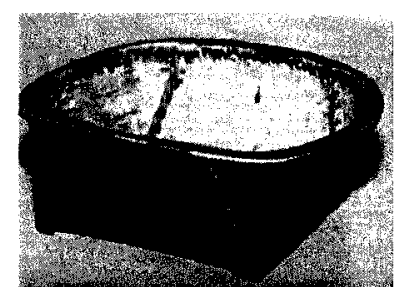

\section{CMC VI B 128}

Wet'suwet'en

Hazelton

H.I. Smith

1925

L. $16 \mathrm{~cm}, W .17 .6 \mathrm{~cm}$,

H. $6.5 \mathrm{~cm}$.

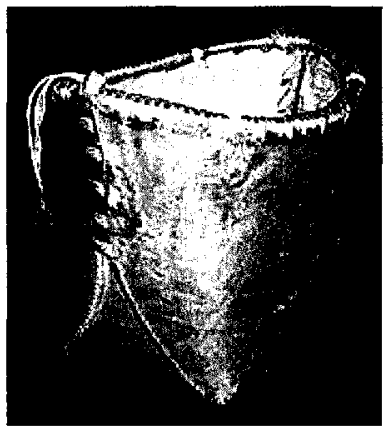

\section{CMC VI B 132}

Ulkatcho

Bella Coola

H.I. Smith

1922

L. $17.5 \mathrm{~cm}, W .20 \mathrm{~cm}$,

H. $23 \mathrm{~cm}$.

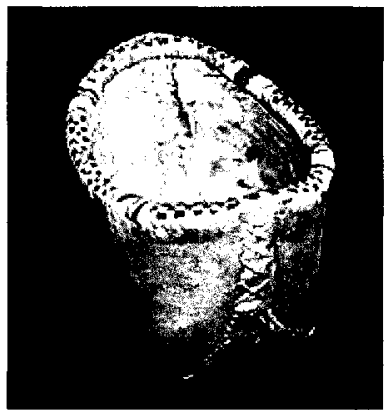

CMC VI B 135

Ulkatcho

Bella Coola

H.I. Smith

1922

L. $14.5 \mathrm{~cm}, W .10 \mathrm{~cm}$,

H. $11.5 \mathrm{~cm}$.

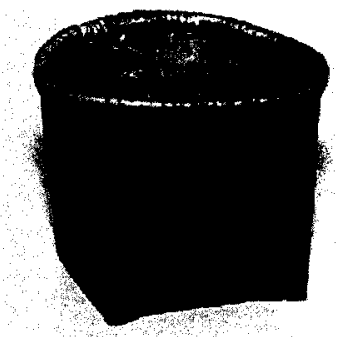

CMC V B 130

Wet'suwet'en

Hazelton

H.I. Smith

1925

L. $13 \mathrm{~cm}, W .11 .5 \mathrm{~cm}$,

$\mathrm{H} .10 \mathrm{~cm}$.

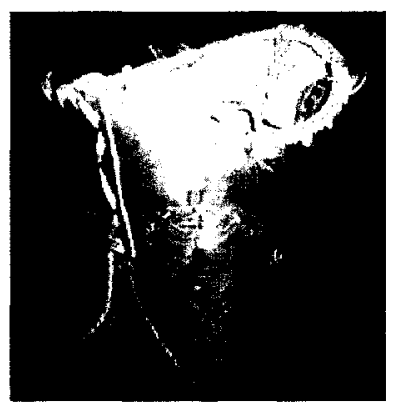

CMC VI B 133

Ulkatcho

Bella Coola

H.I. Smith

1922

L. $23.5 \mathrm{~cm}, W .17 .5 \mathrm{~cm}$,

$\mathrm{H} .21 \mathrm{~cm}$.

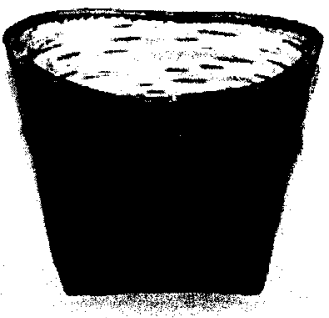

CMC VI B 137, view 1

Wet'suwet'en

Upper Skeena

C.M. Barbeau

1923

L. $29 \mathrm{~cm}, W .21 .5 \mathrm{~cm}$,

$H .26 \mathrm{~cm}$. 


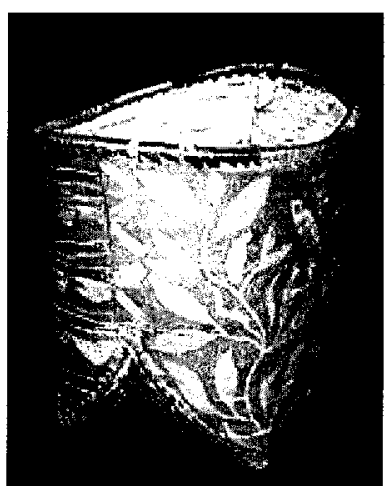

CMC VI B 137, view 2

Wet'suwet'en

Upper Skeena

C.M. Barbeau

1923

L. $29 \mathrm{~cm}, W .21 .5 \mathrm{~cm}$,

$H .26 \mathrm{~cm}$.

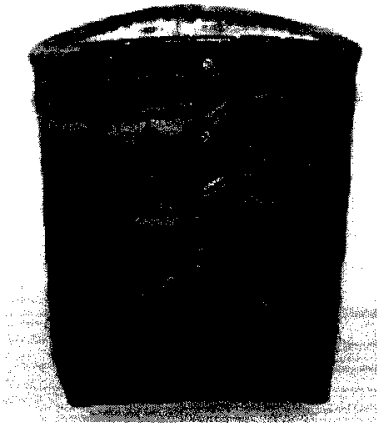

CMC VI B 137, view 5

Wet'suwet'en

Upper Skeena

C.M. Barbeau

1923

L. $29 \mathrm{~cm}, W .21 .5 \mathrm{~cm}$,

$\mathrm{H} .26 \mathrm{~cm}$.

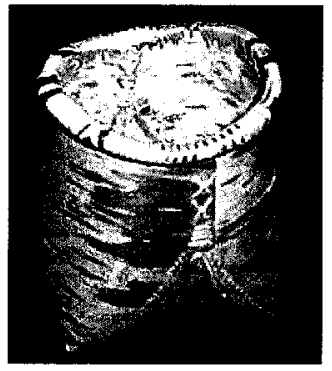

CMC VI B 140

Carrier

Stuart Lake

Rev. A.G. Morice

1892

L. $12.5 \mathrm{~cm}, W .11 .5 \mathrm{~cm}$,

H. $15 \mathrm{~cm}$.

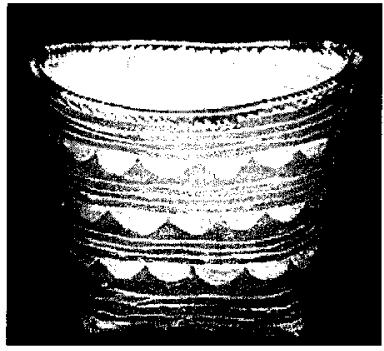

CMC VI B 137, view 3

Wet'suwet'en

Upper Skeena

C.M. Barbeau

1923

L. $29 \mathrm{~cm}, W .21 .5 \mathrm{~cm}$,

H. $26 \mathrm{~cm}$.

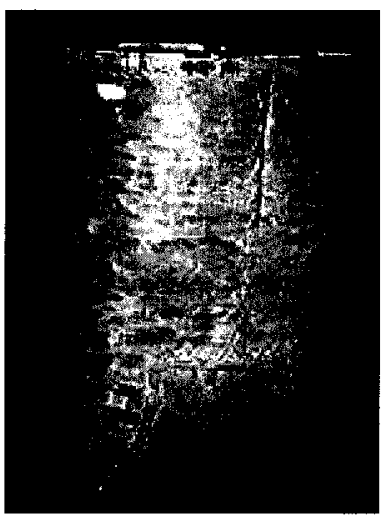

\section{CMC VI B 138}

Carrier

Stuart Lake

Rev. A.G. Morice

1892

L. $37 \mathrm{~cm}, W .31 \mathrm{~cm}$

$\mathrm{H} .40 \mathrm{~cm}$.

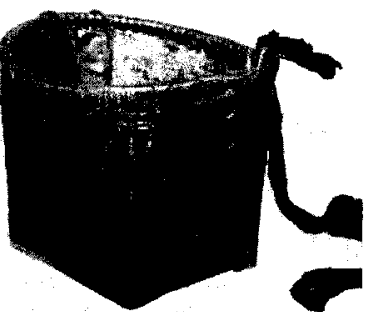

CMC VI B 141

Wet'suwet'en

Hazelton or Kisgaga [sic]

C.M. Barbeau

1920

L. $18.5 \mathrm{~cm}, W .16 .2 \mathrm{~cm}$

H. $14.5 \mathrm{~cm}$.

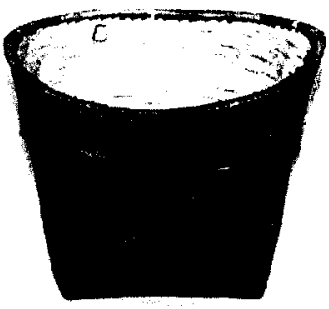

CMC VI B 137, view 4

Wet'suwet'en

Upper Skeena

C.M. Barbeau

1923

L. $29 \mathrm{~cm}, W .21 .5 \mathrm{~cm}$,

$H .26 \mathrm{~cm}$.

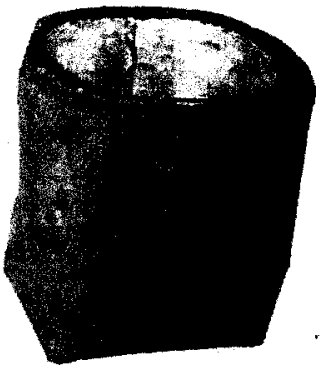

\section{CMC VI B 139}

Carrier

Stuart Lake

Rev. A.G. Morice

1892

L. $28 \mathrm{~cm}, W .26 \mathrm{~cm}$,

$\mathrm{H} .30 \mathrm{~cm}$.

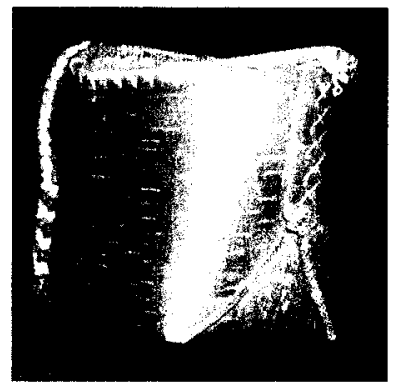

CMC VI B 331

Wet'suwet'en

Hazelton

H.I. Smith

1925

L. $20.5 \mathrm{~cm}, W .13 .5 \mathrm{~cm}$,

H. $15.5 \mathrm{~cm}$. 


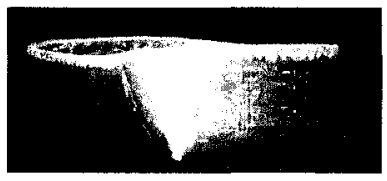

CMC VI B 333

Wet'suwet'en

Hazelton

C.M. Barbeau

1925

L. $42 \mathrm{~cm}, W .27 .5 \mathrm{~cm}$,

H. $10.5 \mathrm{~cm}$.

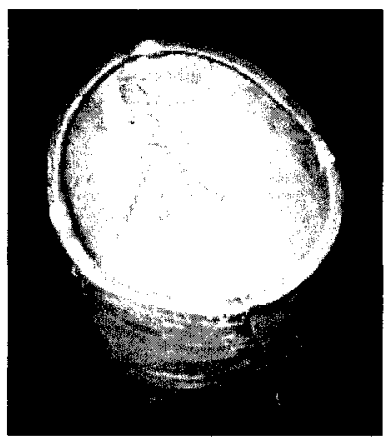

RBCM 322, view 2

Wet'suwet'en

Upper Skeena River

Mrs. Houston Colln.

Date $\mathrm{n} / \mathrm{a}$

L. $16 \mathrm{~cm}, W .13 \mathrm{~cm}$

$\mathrm{H} .11 \mathrm{~cm}$.

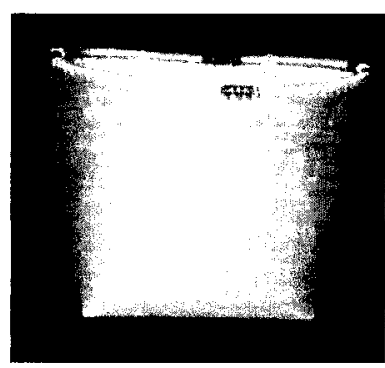

RBCM 4297

Wet'suwet'en

Babine Area

L. $25 \mathrm{~cm}, W .17 \mathrm{~cm}$,

H. $18 \mathrm{~cm}$

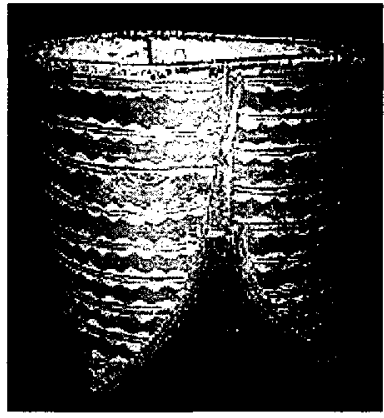

CMC VI B 334, view 1

Wet'suwet'en

Hazelton

C.M. Barbeau

1923

L. $47 \mathrm{~cm}, W .40 \mathrm{~cm}$,

$H .36 \mathrm{~cm}$.

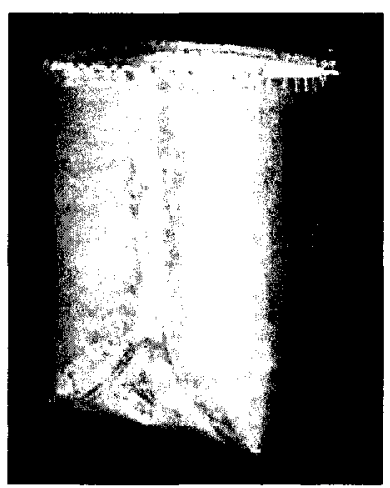

\section{RBCM 2934}

Carrier

Nautley Ranch, Fraser Lake

Lt. F.C. Swannell Colln.

1909. Purchased 1917

L. $26 \mathrm{~cm}, W .21 \mathrm{~cm}$

$\mathrm{H} .30 \mathrm{~cm}$

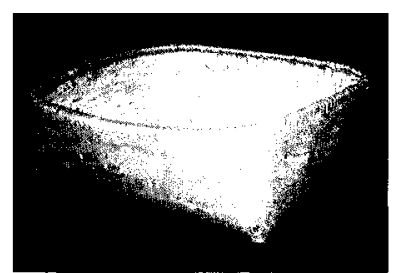

RBCM 4299

Wet'suwet'en

Babine Area

L. $38 \mathrm{~cm}, W .14 \mathrm{~cm}$,

$\mathrm{H} .13 \mathrm{~cm}$.

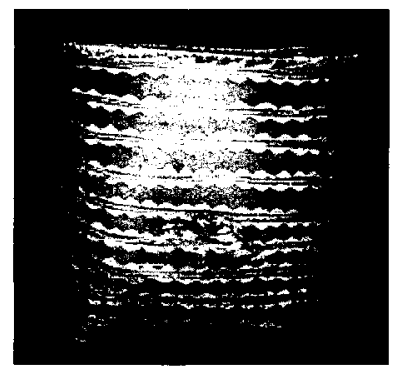

CMC VI B 334, view 2

Wet'suwet'en

Hazelton

C.M. Barbeau

1923

L. $47 \mathrm{~cm}, W .40 \mathrm{~cm}$,

H. $36 \mathrm{~cm}$.

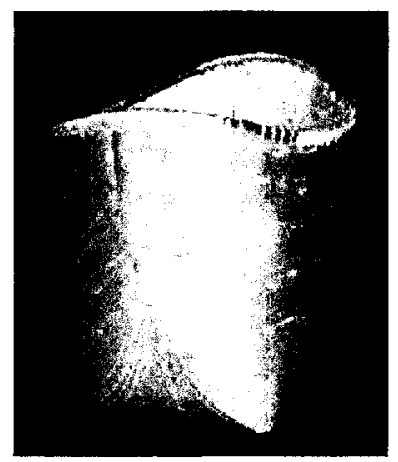

RBCM 4296

Wet'suwet'en

Babine Area

Mrs. W. F. Robertson Colln.

1929

L. $26 \mathrm{~cm}, W .18 \mathrm{~cm}$

$H .23 \mathrm{~cm}$.

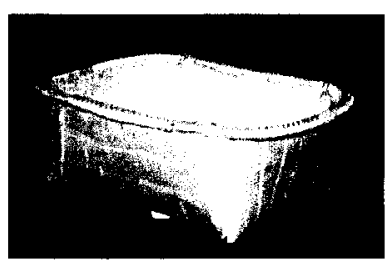

RBCM 4300

Wet'suwet'en

Babine Area

L. $18 \mathrm{~cm}, W .15 \mathrm{~cm}$,

$\mathrm{H} .3 \mathrm{~cm}$. 


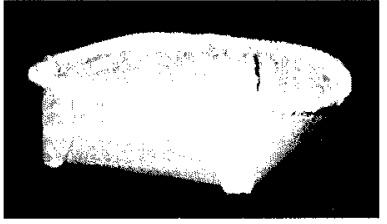

RBCM 4468

Carrier

Location $\mathrm{n} / \mathrm{a}$

Lt. F.C. Swannell Coll'n.

1930

L. $18 \mathrm{~cm}, W .15 \mathrm{~cm}$,

H. $6 \mathrm{~cm}$.

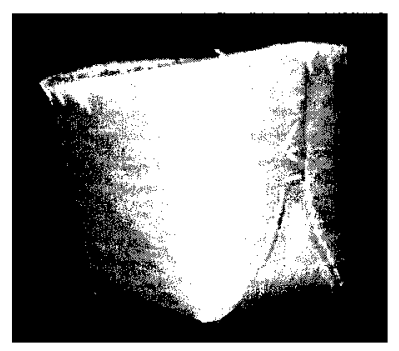

RBCM 4471

Dene, Carrier

Lt. F.C. Swannell Coll'n.

1930

L. $25 \mathrm{~cm}, W .21 \mathrm{~cm}$,

H. $7 \mathrm{~cm}$.

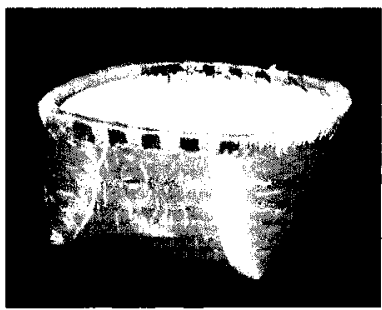

RBCM 4486

Carrier, Stoney Creek

Vanderhoof

Mrs. Washington

Before 1931

L. $19 \mathrm{~cm}, W .18 \mathrm{~cm}$,

$\mathrm{H} .9 \mathrm{~cm}$.

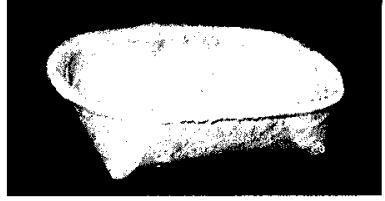

RBCM 4469

Carrier

Lt. F.C. Swannell Coll'n.

1930

L. $16 \mathrm{~cm}, W .12 \mathrm{~cm}$,

$H .5 \mathrm{~cm}$.

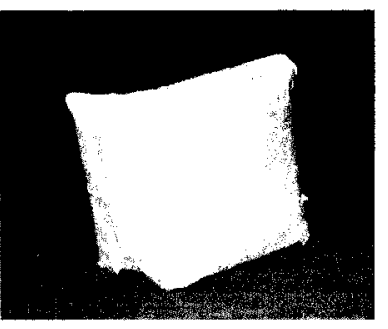

RBCM 4472

Carrier

Lt. F.C. Swannell Coll'n.

1930

L. $10 \mathrm{~cm}, W .8 \mathrm{~cm}$,

H. $8 \mathrm{~cm}$.

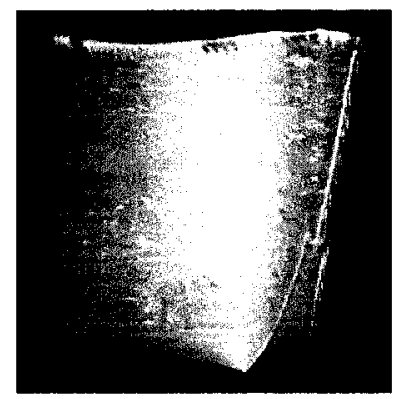

RBCM 7070, view 1

Carrier

Fort Fraser

Purchase by Museum from

Mr. Maxim George

1951

L. $38 \mathrm{~cm}, W .38 \mathrm{~cm}$,

$\mathrm{H} .38 \mathrm{~cm}$.

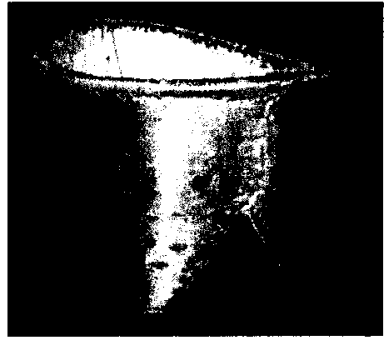

RBCM 4470

Carrier

Lt. F.C. Swannell Coll'n

1930

L. $28 \mathrm{~cm}, W .23 \mathrm{~cm}$

$\mathrm{H} .20 \mathrm{~cm}$

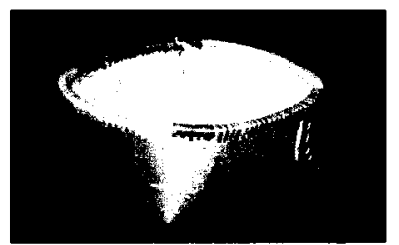

RBCM 4485

Carrier, Stony Creek

Vanderhoof

Mrs. Washington

1931

L. $20 \mathrm{~cm}, W .18 \mathrm{~cm}$,

H. $9 \mathrm{~cm}$.

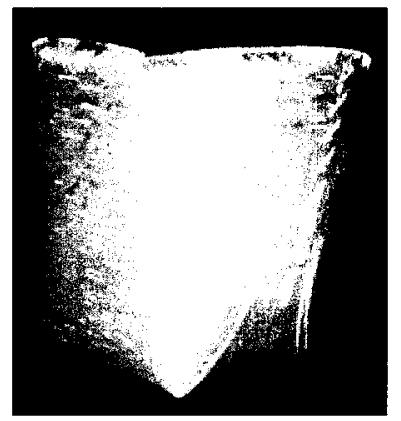

RBCM 7070, view 2

Carrier

Fort Fraser

Purchase by Museum from

Mr. Maxim George

1951

L. $38 \mathrm{~cm}, W .38 \mathrm{~cm}$,

$\mathrm{H} .38 \mathrm{~cm}$. 


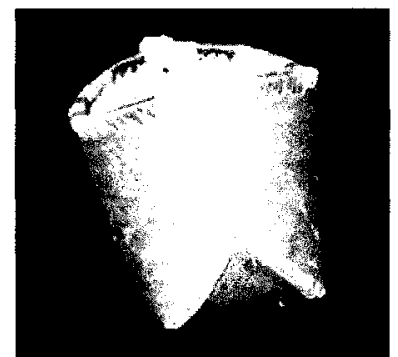

RBCM 8738

Carrier

Nautley Reserve/ Fort Fraser Purchase by Museum from Mr. Maxim George 1957

L. $23 \mathrm{~cm}, W .39 \mathrm{~cm}$,

$\mathrm{H} .14 \mathrm{~cm}$.

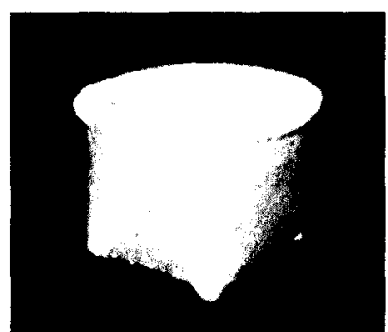

RBCM 9258

Carrier

Natliwoten, F ort Fraser

W. Duff purchase from Mr.

Maxim George

1960

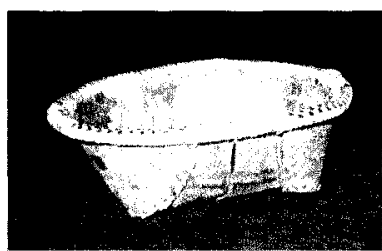

RBCM 10488

Carrier, Alkatcho [sic]

Tanya Lake

Lt. F.C. Swannell Coll'n.

Before 1961

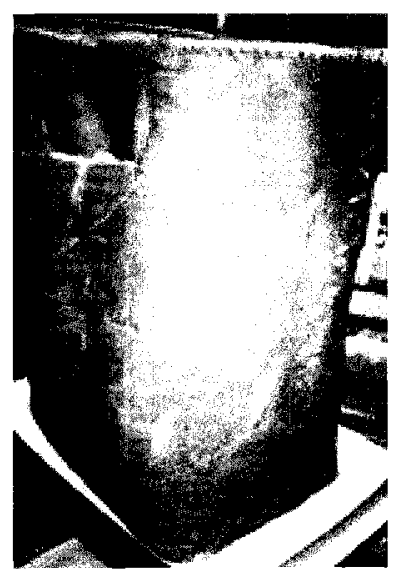

RBCM 8780, view 1

Morley Shire

1957

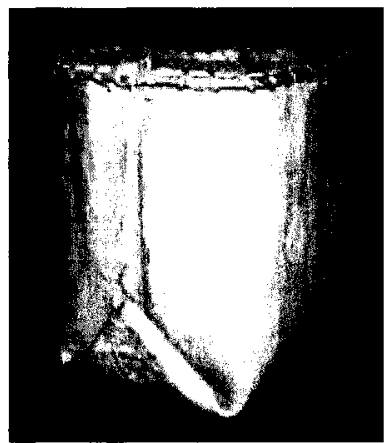

RBCM 9262

Carrier

Fort Fraser

Wilson Duff purchase 1960

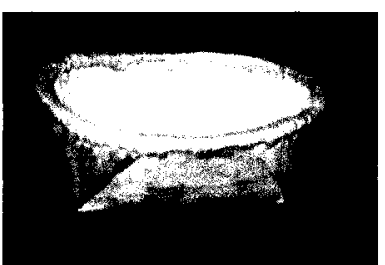

RBCM 10530, view 1

Stikine Dene

George Colln / C.F.

Newcombe

1961

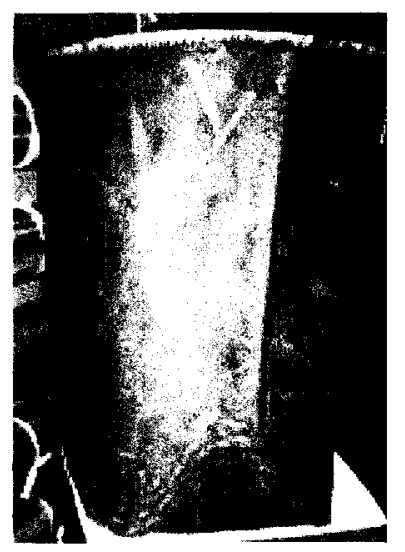

RBCM 8780, view 2

Morley Shire

1957

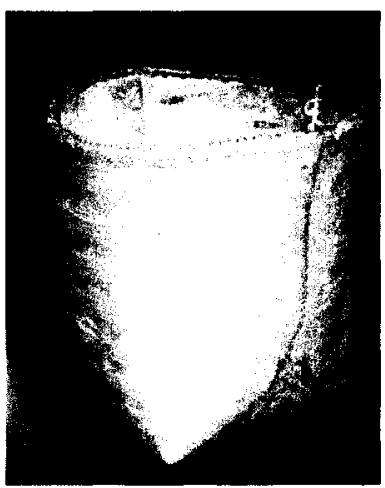

RBCM 10329

Carrier

Dr. W.F. John Tolmie Coll'n. ca. 1852 (1961)

L. $28 \mathrm{~cm}, W .28 \mathrm{~cm}$,

$\mathrm{H} .23 \mathrm{~cm}$.

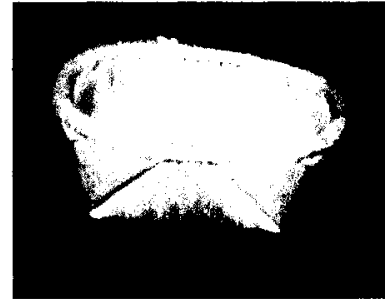

RBCM 10530, view 2

Stikine Dene

George Coll'n. / C.F.

Newcombe

1961 


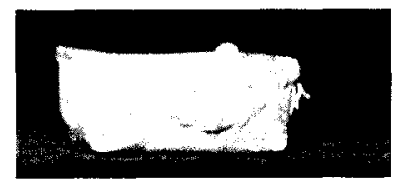

RBCM 10530, view 3

Stikine Dene

George Colln / C.F.

Newcombe

1961

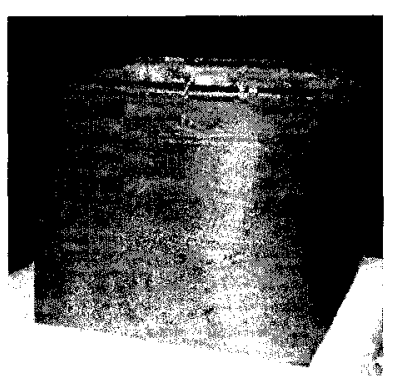

RBCM 10578, view 1

Tsimshian (?) [sic]

Tomlinson \& Wood Colln /

C.F. Newcombe

1961

L. $14 \mathrm{~cm}, W .11 \mathrm{~cm}$,

H. $10 \mathrm{~cm}$.

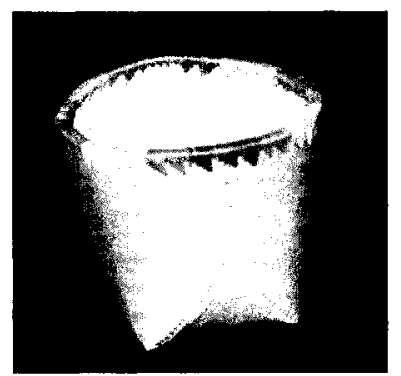

RBCM 11072

Carrier

Mrs. Melba Menzie Coll'n.

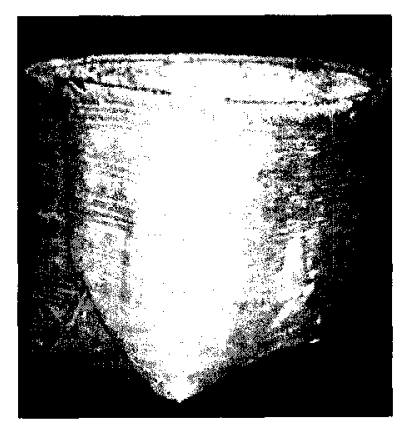

RBCM 10536, view 1

Carrier

Smith Colln / C.F.

Newcombe

1961

L. $38 \mathrm{~cm}, W .34 \mathrm{~cm}$,

H. $28 \mathrm{~cm}$.

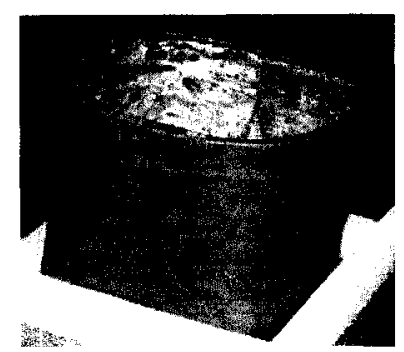

RBCM 10578, view 2

Tsimshian (?) [sic]

Tomlinson \& Wood Colln /

C.F. Newcombe

1961

L. $14 \mathrm{~cm}, W .11 \mathrm{~cm}$,

H. $10 \mathrm{~cm}$.

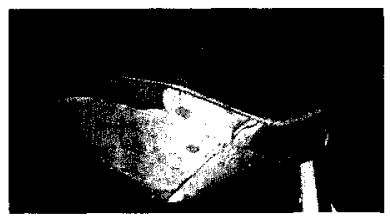

RBCM 11478

Carrier

Charles F. Newcombe Coll'n. 1962

L. $43 \mathrm{~cm}, W .33 \mathrm{~cm}$,

$\mathrm{H} .17 \mathrm{~cm}$.

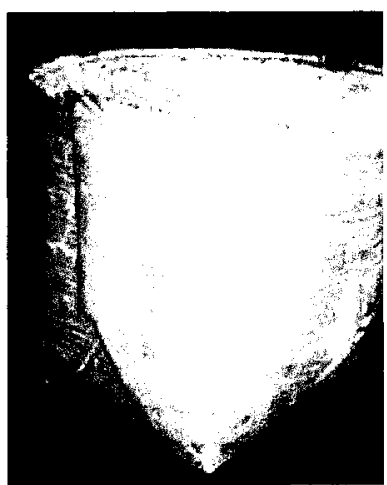

RBCM 10536, view 2

Carrier

Smith Colln / C.F.

Newcombe

1961

L. $38 \mathrm{~cm}, W .34 \mathrm{~cm}$

$\mathrm{H} .28 \mathrm{~cm}$.

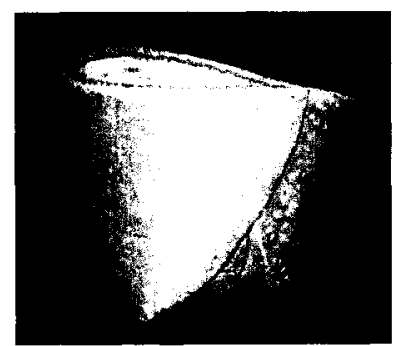

RBCM 10777

Carrier

Miss Hilda D. Harris Colln /

C.F. Newcombe

1961

$23 \mathrm{~cm}$ by $18 \mathrm{~cm}$.

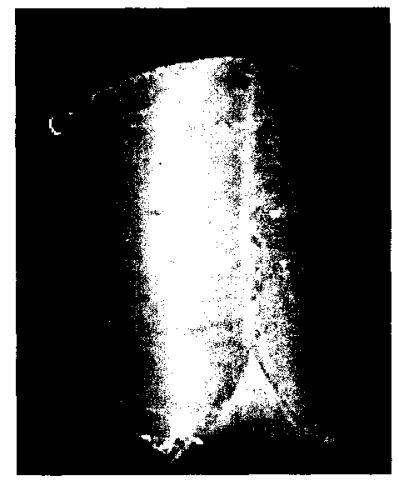

RBCM 11480

Carrier

Charles F. Newcombe Coll'n. 1962

$\mathrm{L} .33 \mathrm{~cm}, \mathrm{~W} .25 \mathrm{~cm}$,

$\mathrm{H} .30 \mathrm{~cm}$. 


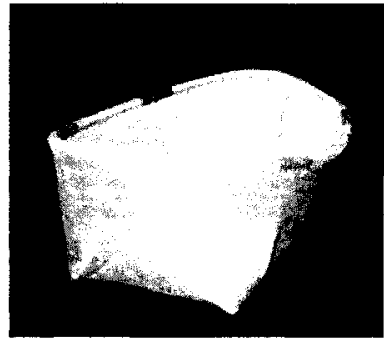

RBCM 11546

Carrie

Oswald Meredith Jones

Coll'n.

1962

L. $33 \mathrm{~cm}, W .19 \mathrm{~cm}$,

H. $10 \mathrm{~cm}$.

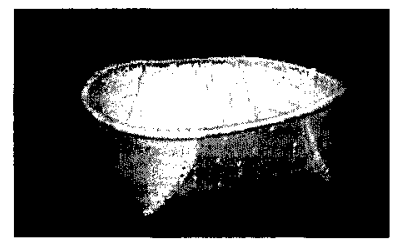

RBCM 11551

Carrier

Oswald Meredith Jones

Coll'n.

1962

$20 \mathrm{~cm}, W .18 \mathrm{~cm}$,

H. $8 \mathrm{~cm}$

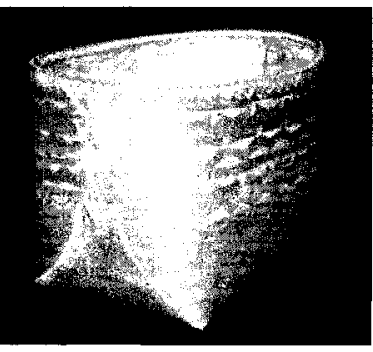

RBCM 11555

Carrier

Oswald Meredith Jones

Coll'n.

1962

L. $29 \mathrm{~cm}, W .22 \mathrm{~cm}$

H. $20 \mathrm{~cm}$.

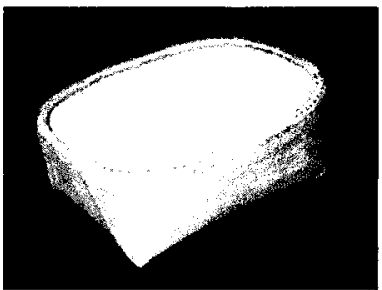

RBCM 11547

Carrier

Oswald Meredith Jones

Coll'n.

1962

L. $20 \mathrm{~cm}, W .15 \mathrm{~cm}$,

H. $8 \mathrm{~cm}$.

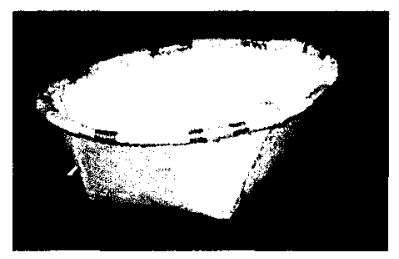

RBCM 11549

Carrier

Oswald Meredith Jones

Coll'n.

1962

L. $21 \mathrm{~cm}, W .19 \mathrm{~cm}$,

$\mathrm{H} .7 \mathrm{~cm}$.

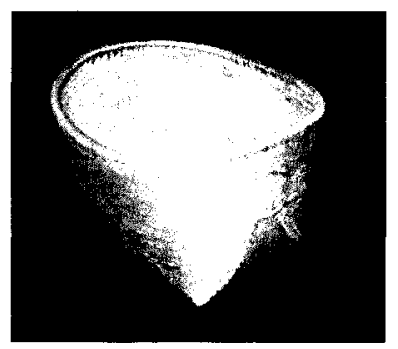

RBCM 11552

Carrier

Oswald Meredith Jones

Coll'n.

1962

L. $28 \mathrm{~cm}, W .20 \mathrm{~cm}$,

H. $16 \mathrm{~cm}$.

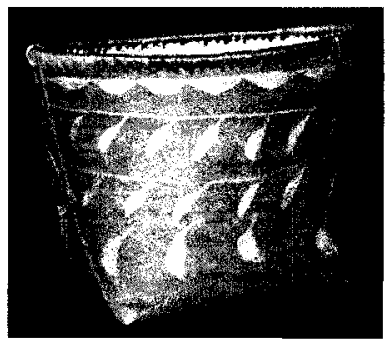

RBCM 11556, view 1

Carrier

Oswald Meredith Jones

Coll'n.

1962

L. $25 \mathrm{~cm}, W .18 \mathrm{~cm}$,

$\mathrm{H} .20 \mathrm{~cm}$.

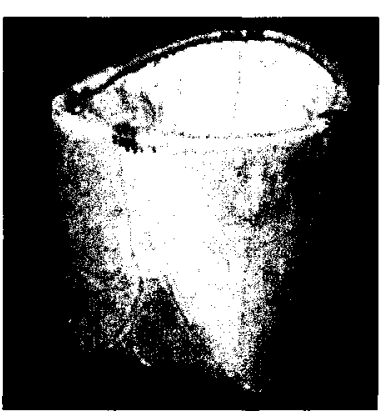

RBCM 11553

Carrier

Oswald Meredith Jones

Coll'n.

1962

L. $24 \mathrm{~cm}, 17 \mathrm{~cm}$,

H. $18 \mathrm{~cm}$.

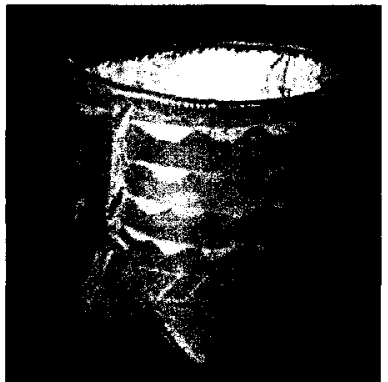

RBCM 11556, view 2

Carrier

Oswald .Meredith Jones

Coll'n.

1962

L. $25 \mathrm{~cm}, W .18 \mathrm{~cm}$,

$\mathrm{H} .20 \mathrm{~cm}$. 


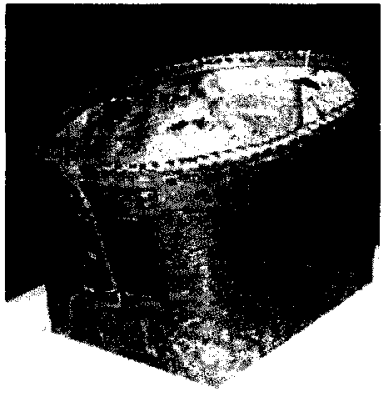

RBCM 12673

Carrier

Alan W. Ford Coll'n.

1966

L. $25 \mathrm{~cm}, W .34 \mathrm{~cm}$,

H. $27 \mathrm{~cm}$.

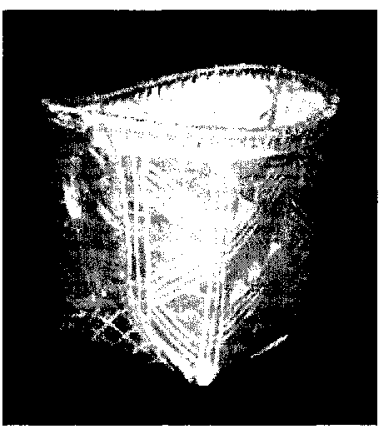

RBCM 12675, view 2

Carrier

Alan W. Ford

1966

L. $23 \mathrm{~cm}, W .29 \mathrm{~cm}$,

$\mathrm{H} .21 \mathrm{~cm}$

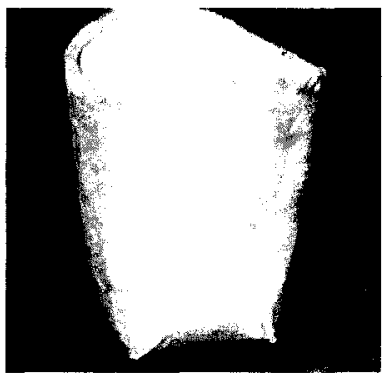

RBCM 14147

Carrier

Mrs. Ross purchased at

Maynard's Auction

December 1973

L. $57 \mathrm{~cm}, W .40 \mathrm{~cm}$,

$H .58 \mathrm{~cm}$.

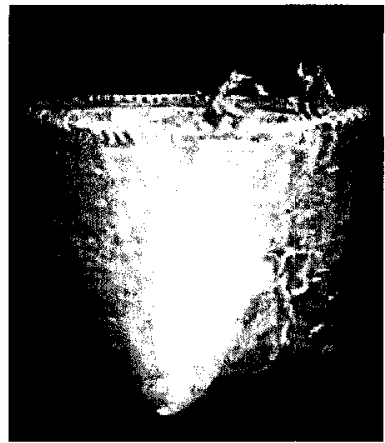

RBCM 12674

Carrier

Alan W. Ford Coll'n.

1966

L. $23 \mathrm{~cm}, W .32 \mathrm{~cm}$,

$\mathrm{H} .23 \mathrm{~cm}$

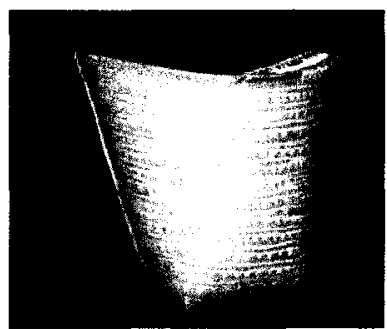

RBCM 13604, view 1

Carrier

1972

L. $55 \mathrm{~cm}, W .48 \mathrm{~cm}$,

$\mathrm{H} .53 \mathrm{~cm}$.

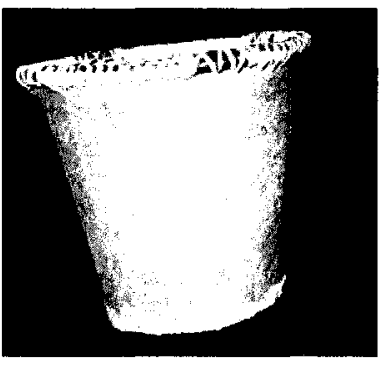

RBCM 14525, view 1

Carrier

Fort Fraser

P.L. MacNair purchase for

Museum at K'San Sales,

Hazelton

1974

$H .20 \mathrm{~cm}$, Dia. $21 \mathrm{~cm}$.

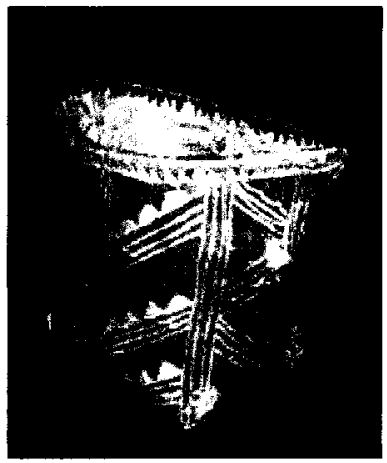

RBCM 12675, view 1

Carrier

Alan W. Ford Coll'n

1966

L. $23 \mathrm{~cm}, W .29 \mathrm{~cm}$

$\mathrm{H} .21 \mathrm{~cm}$.

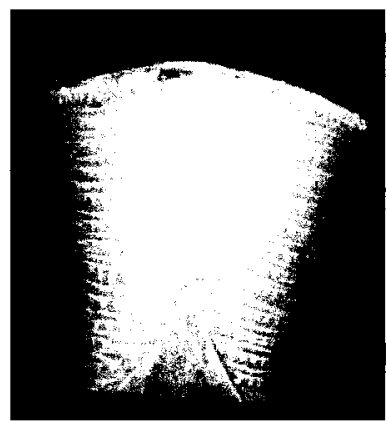

RBCM 13604, view 2

Carrier

1972

L. $55 \mathrm{~cm}, W .48 \mathrm{~cm}$,

$\mathrm{H} .53 \mathrm{~cm}$.

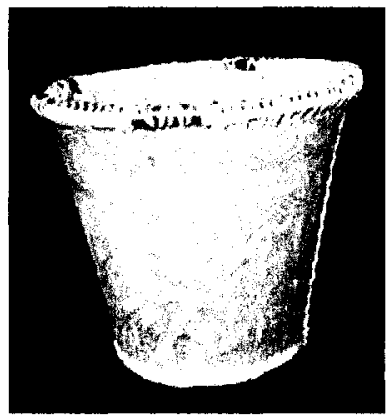

RBCM 14525, view 2

Carrier

Fort Fraser

P.L. MacNair purchase for

Museum at K'San Sales,

Hazelton

1974

H. $20 \mathrm{~cm}$, Dia. $21 \mathrm{~cm}$. 


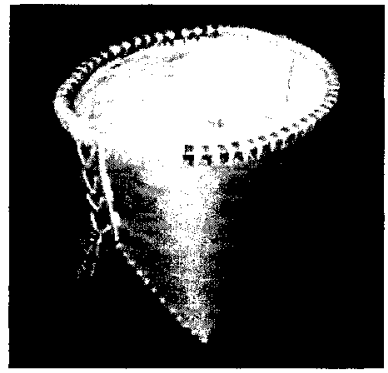

RBCM 14970

Carrier

Mrs. Charlotte Cox Coll'n. 1951

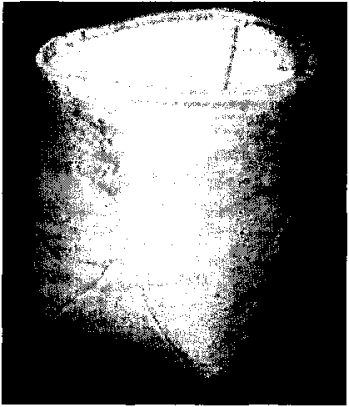

RBCM 16234

Wet'suwet'en

Skeena River

Mrs. H. Marion Dallain

Coll'n.

1979

L. $28 \mathrm{~cm}, W .30 \mathrm{~cm}$,

H. $23 \mathrm{~cm}$.

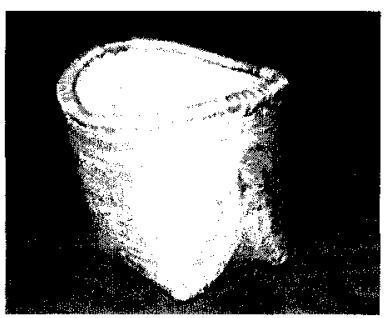

RBCM 16237

Wet'suet'en

Skeena River

Mrs. H. M arion Dallain

Coll'n.

1979

L. $12 \mathrm{~cm}, W .95 \mathrm{~cm}$,

$\mathrm{H} .10 \mathrm{~cm}$.

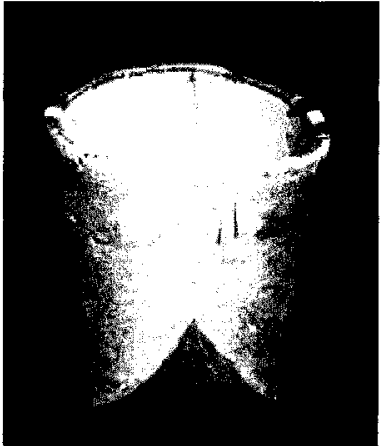

RBCM 15916

Carrier

Mrs. Ursula Lalonde Coll'n. 1977

L. $23 \mathrm{~cm}, W .18 \mathrm{~cm}$

$\mathrm{H} .19 \mathrm{~cm}$.

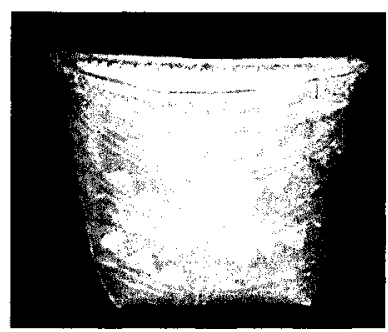

RBCM 16235

Wet'suwet'en

Skeena River

Mrs. H. Marion Dallain

Coll'n.

1979

L. $22 \mathrm{~cm}, W .16 \mathrm{~cm}$

$\mathrm{H} .18 \mathrm{~cm}$.

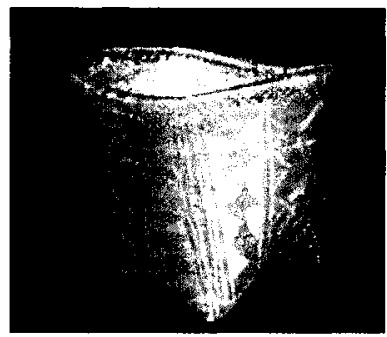

\section{RBCM 16875, view 1}

Carrier

Purchase by Museum from

Una Langmann Antiques-Art

Gallery, Vancouver

1979

L. $23 \mathrm{~cm}, W .15 \mathrm{~cm}$

H. $18 \mathrm{~cm}$

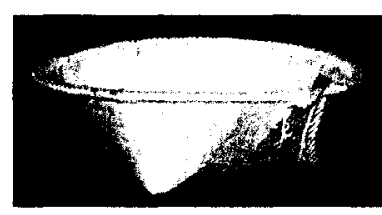

RBCM 15918

Carrier

Ursula Lalonde Coll'n.

1977

L. $38 \mathrm{~cm}, W .32 \mathrm{~cm}$,

H. $33.8 \mathrm{~cm}$

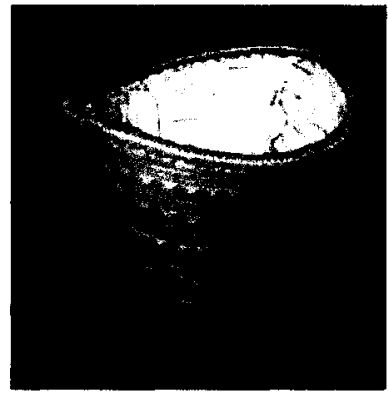

RBCM 16236

Wet'suwet'en

Skeena River

Mrs. H. Marion Dallain

Coll'n.

1979

L. $21 \mathrm{~cm}, W .16 \mathrm{~cm}$,

$\mathrm{H.} 17 \mathrm{~cm}$.

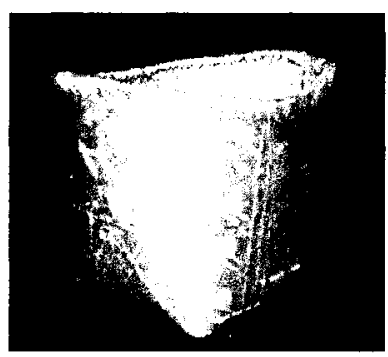

RBCM 16875, view 2

Carrier

Purchase by Museum from

Una Langmann Antiques-Art Gallery

1979

L. $23 \mathrm{~cm}, W .15 \mathrm{~cm}$,

H. $18 \mathrm{~cm}$ 


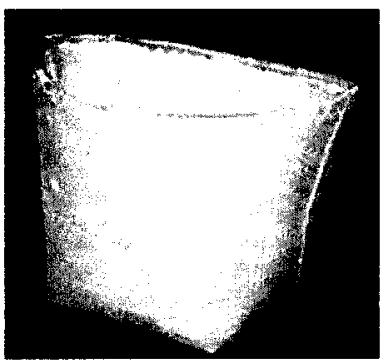

RBCM 17114

Carrier

Mrs. G.M. Carter Coll'n.

1970

L. $31 \mathrm{~cm}, W .21 \mathrm{~cm}$

$\mathrm{H} .26 \mathrm{~cm}$.

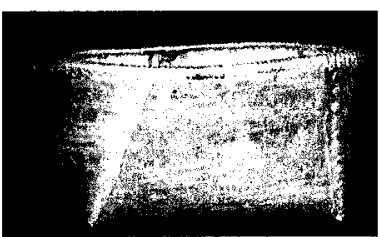

RBCM 19277

Carrier

Mr. W.B. Russell Coll'n. 1991

L. $39 \mathrm{~cm}, W .34 \mathrm{~cm}$,

$\mathrm{H} .20 \mathrm{~cm}$.

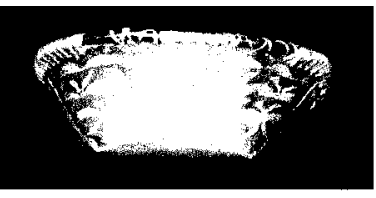

RBCM 19282

\section{Carrier}

Mr. W.B. Russell Coll'n.

1991

L. $28 \mathrm{~cm}, W .16 \mathrm{~cm}$,

$\mathrm{H} .10 \mathrm{~cm}$.

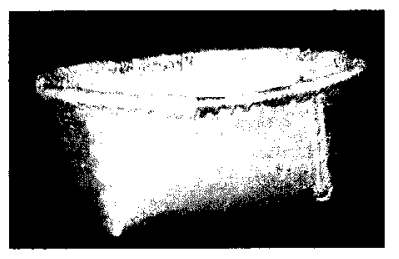

RBCM 18179

Carrier

Mildred Valley Thornton

Coll'n.

1965

L. $24 \mathrm{~cm}, W .18 . \mathrm{cm}$,

$\mathrm{H} .120 \mathrm{~cm}$.

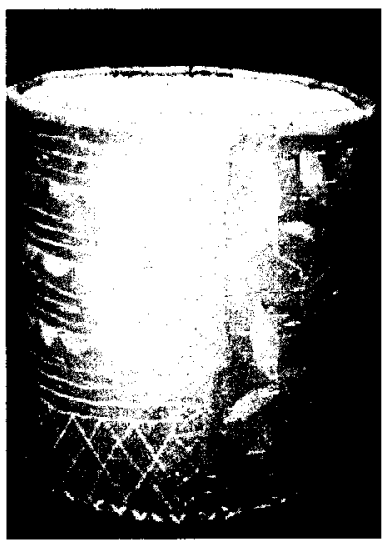

RBCM 18242

Carrier

Mrs. Dorothy Sherwood Coll'n.

1986

H. $30 \mathrm{~cm}$, Dia. $39 \mathrm{~cm}$.

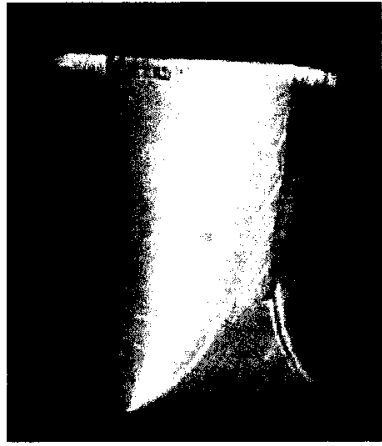

RBCM 19280

Carrier

Mr. W.B. Russell Coll'n. 1991

L. $29 \mathrm{~cm}, W .25 \mathrm{~cm}$,

$\mathrm{H} .31 \mathrm{~cm}$.

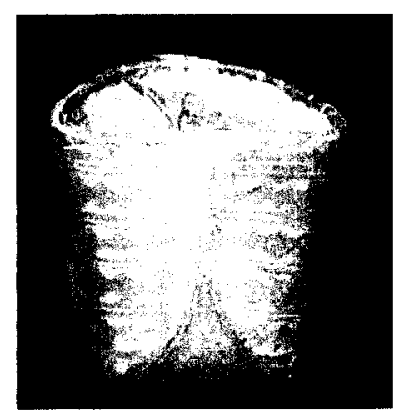

RBCM 19281

Carrier

Mr. W.B. Russell Coll'n. 1991

L. $22 \mathrm{~cm}, W .20 \mathrm{~cm}$,

$\mathrm{H} .21 \mathrm{~cm}$. 


\section{Algonquin Birch Bark Baskets}

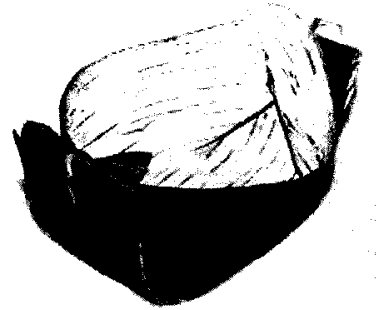

CMC III L 11

Algonquin

Maniwaki

E. Sapir

1912

L. $24 \mathrm{~cm}, W .18 \mathrm{~cm}$,

H. $12 \mathrm{~cm}$.

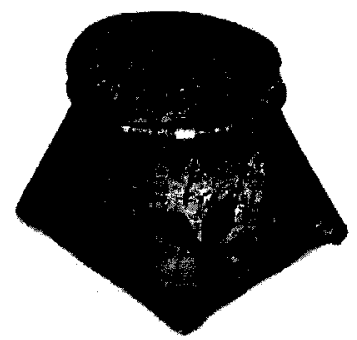

CMC III L 20

Algonquin

Maniwaki

E. Sapir

1912

L. $14 \mathrm{~cm}, W .13 \mathrm{~cm}$,

H. $13 \mathrm{~cm}$.

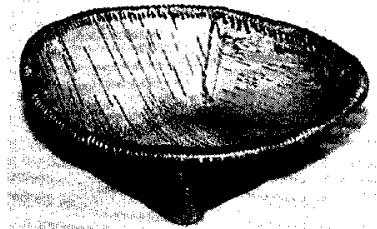

CMC III L 29

Algonquin

Maniwaki

E. Sapir

1912

L. $32 \mathrm{~cm}, W .26 \mathrm{~cm}$,

$\mathrm{H} .11 \mathrm{~cm}$.

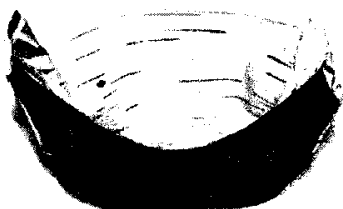

CMC III L 12

Algonquin

Maniwaki

E. Sapir

1912

L. $16 \mathrm{~cm}, W .13 \mathrm{~cm}$,

$\mathrm{H} .10 \mathrm{~cm}$

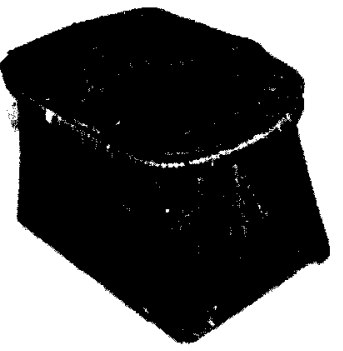

CMC III L 24

Algonquin

Maniwaki

E. Sapir

1912

L. $22 \mathrm{~cm}, W .15 \mathrm{~cm}$,

H. $15 \mathrm{~cm}$.

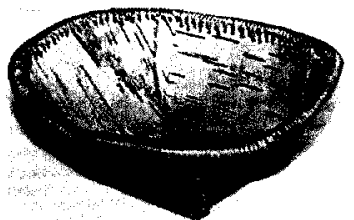

\section{CMC III L 30}

Algonquin

Maniwaki

E. Sapir

1912

$\mathrm{n} / \mathrm{a}$

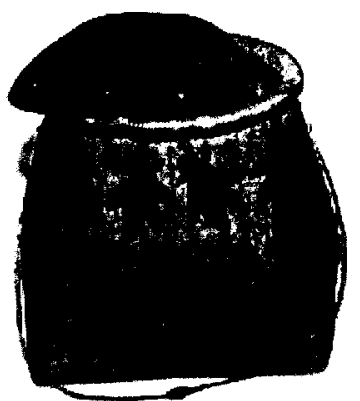

CMC III L 19

Algonquin

Maniwaki

E. Sapir

1912

L. $18 \mathrm{~cm}, W .14 \mathrm{~cm}$,

H. $18 \mathrm{~cm}$.

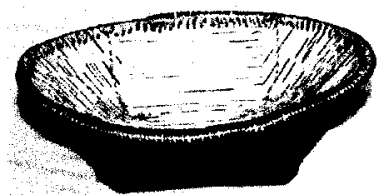

\section{CMC III L 28}

Algonquin

Maniwaki

E. Sapir

1912

L. $38 \mathrm{~cm}, W .32 \mathrm{~cm}$,

H. $13 \mathrm{~cm}$.

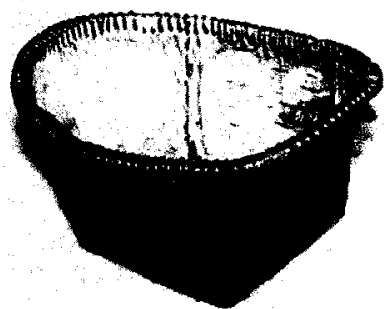

CMC III L 31

Algonquin

Maniwaki

E. Sapir

1912

$\mathrm{L} 11 \mathrm{~cm}, W .24 \mathrm{~cm}$,

$H .20 \mathrm{~cm}$. 


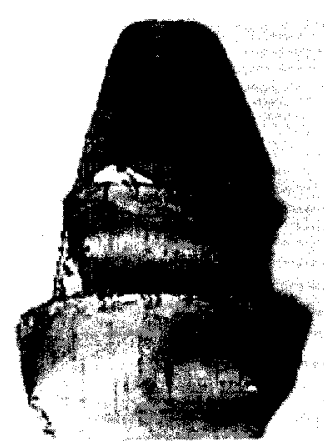

CMC III L 32

Algonquin

Maniwaki

E. Sapir

1912

L. $18 \mathrm{~cm}, W .11 .8 \mathrm{~cm}$,

H. $34 \mathrm{~cm}$.

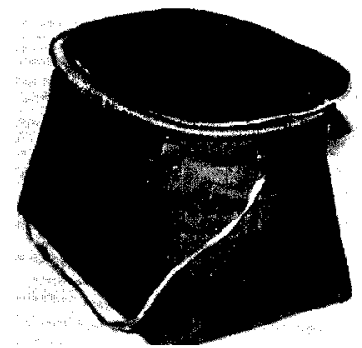

CMC III L 35

Algonquin

Maniwaki

E. Sapir

1912

L. $33 \mathrm{~cm}, W .21 \mathrm{~cm}$,

$\mathrm{H} .21 \mathrm{~cm}$.

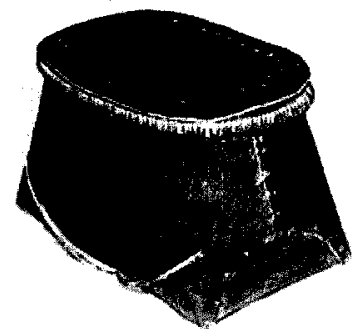

\section{CMC III L 38}

Algonquin

Maniwaki

E. Sapir

1912

L. $24 \mathrm{~cm}, W .14 \mathrm{~cm}$,

H. $15 \mathrm{~cm}$.

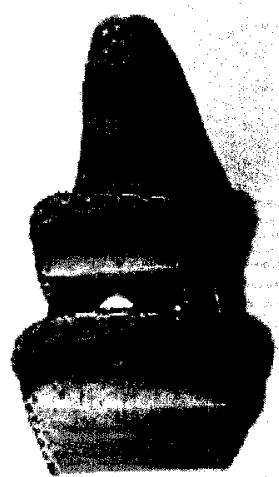

CMC III L 33

Algonquin

Maniwaki

E. Sapir

1912

L. $18 \mathrm{~cm}, W .11 \mathrm{~cm}$,

$\mathrm{H} .42 \mathrm{~cm}$.

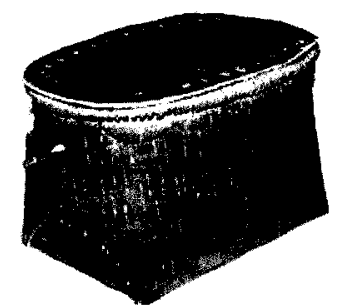

CMC III L 36

Algonquin

Maniwaki

E. Sapir

1912

L. $30 \mathrm{~cm}, W .20 \mathrm{~cm}$,

$H .20 \mathrm{~cm}$

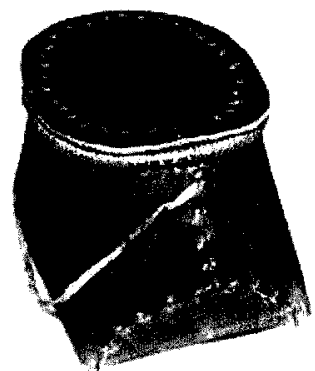

CMC III L 39

Algonquin

E. Sapir

1912

L. $22 \mathrm{~cm}, W .15 \mathrm{~cm}$,

H. $15 \mathrm{~cm}$.

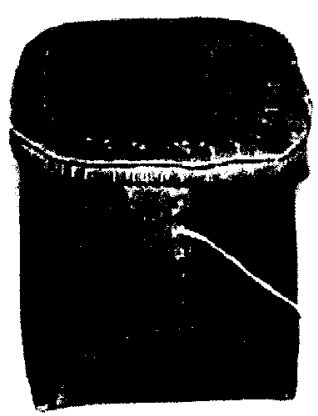

CMC III L 34

Algonquin

Maniwaki

E. Sapir

1912

$\mathrm{L} .25 \mathrm{~cm}, W .16 \mathrm{~cm}$

H. $18 \mathrm{~cm}$.

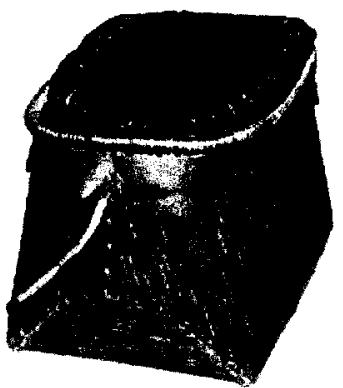

CMC III L 37

Algonquin

Maniwaki

E. Sapir

1912

L. $30 \mathrm{~cm}, W .20 \mathrm{~cm}$,

$\mathrm{H} .19 \mathrm{~cm}$

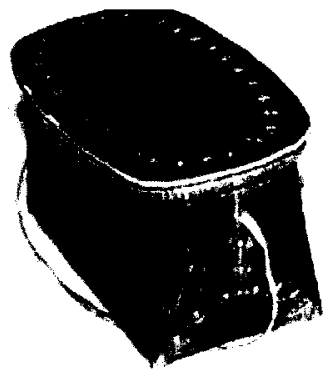

CMC III L 40

Algonquin

Maniwaki

E. Sapir

1912

L. $22 \mathrm{~cm}, W .12 \mathrm{~cm}$

H. $14 \mathrm{~cm}$. 


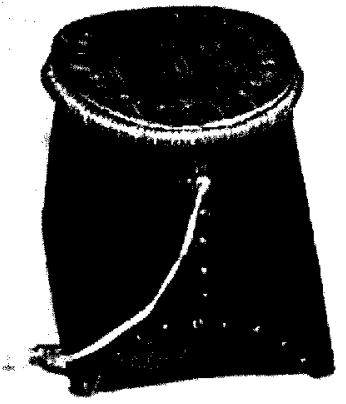

CMC III L, 41

Algonquin

Maniwaki

E. Sapir

1912

L. $20 \mathrm{~cm}, W .15 \mathrm{~cm}$,

H. $18 \mathrm{~cm}$.

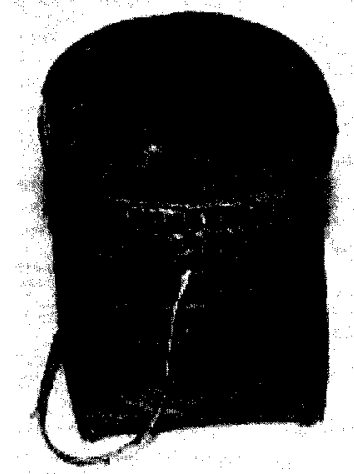

CMC III L 44

Algonquin

Maniwaki

E. Sapir

1912

n/a

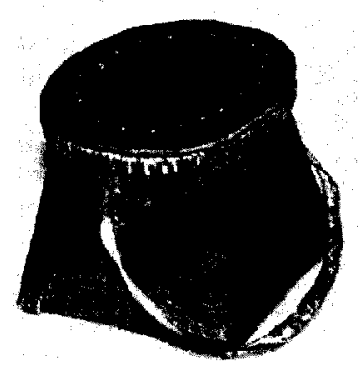

CMC III L 48

Algonquin

Maniwaki

E. Sapir

1912

L. $12 \mathrm{~cm}$, W.n/a,

$\mathrm{H} .10 \mathrm{~cm}$

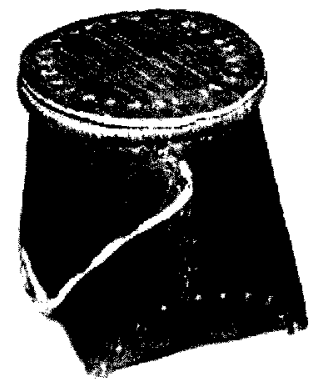

CMC III L 42

Algonquin

Maniwaki

E. Sapir

1912

L. $20 \mathrm{~cm}, W .16 \mathrm{~cm}$,

$\mathrm{H} .17 \mathrm{~cm}$

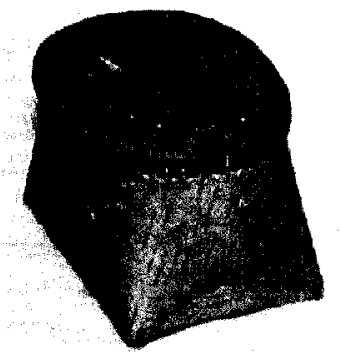

CMC III L 46

Algonquin

Maniwaki

E. Sapir

1912

L. $17 \mathrm{~cm}, W .11 \mathrm{~cm}$,

$H .11 \mathrm{~cm}$.

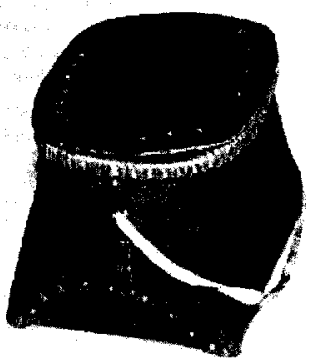

CMC III L 49

Algonquin

Maniwaki

E. Sapir

1912

L. $17 \mathrm{~cm}, W .12 \mathrm{~cm}$,

$\mathrm{H} .13 \mathrm{~cm}$.

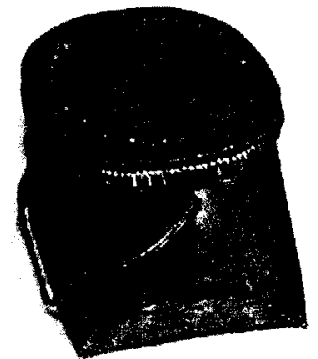

CMC III L 43

Algonquin

Maniwaki

E. Sapir

1912

L. $15 \mathrm{~cm}, W .12 \mathrm{~cm}$,

$\mathrm{H} .11 \mathrm{~cm}$.

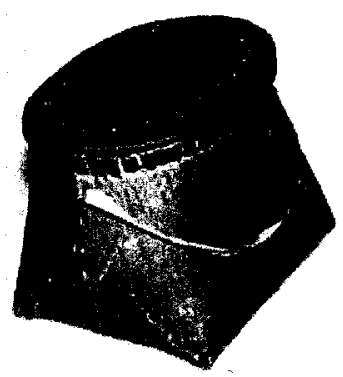

CMC III L 47

Algonquin

Maniwaki

E. Sapir

1912

L. $14 \mathrm{~cm}, W .11 \mathrm{~cm}$,

H. $11 \mathrm{~cm}$

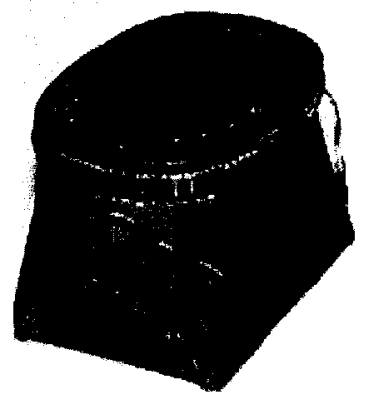

CMC III L 50

Algonquin

Maniwaki

E. Sapir

1912

L. $16 \mathrm{~cm}, W .1 \mathrm{~cm}$,

$\mathrm{H} .12 \mathrm{~cm}$. 


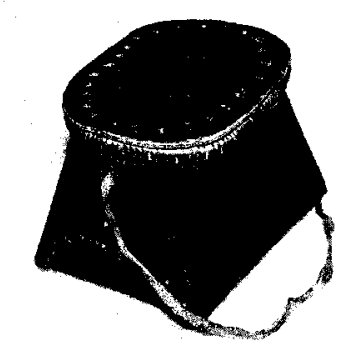

CMC III L 51

Algonquin

Maniwaki

E. Sapir

1912

L. $17 \mathrm{~cm}, W .12 \mathrm{~cm}$

H. $12 \mathrm{~cm}$.

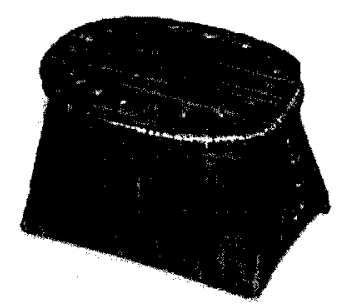

CMC III L 55

Algonquin

Maniwaki

E. Sapir

1912

L. $13 \mathrm{~cm}, W .9 \mathrm{~cm}$,

H. $10 \mathrm{~cm}$

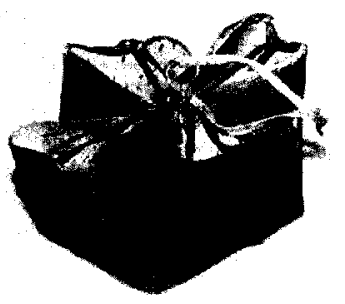

CMC III L 59

Algonquin

Maniwaki

E. Sapir

1912

L. $16 \mathrm{~cm}, W .12 \mathrm{~cm}$,

H. $10 \mathrm{~cm}$.

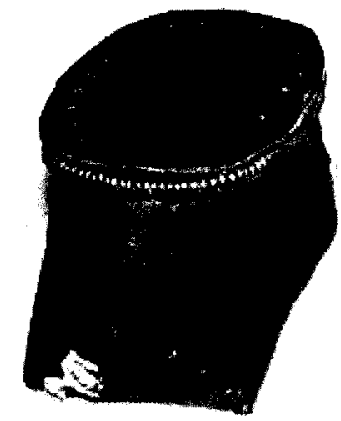

CMC III L 52

Algonquin

Maniwaki

E. Sapir

1913

L. $17 \mathrm{~cm}, W .10 \mathrm{~cm}$

$\mathrm{H} .11 \mathrm{~cm}$.

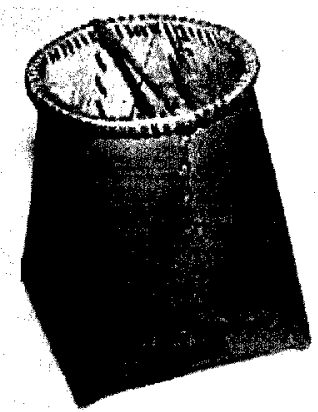

CMC III L 56

Algonquin

Maniwaki

E. Sapir

1912

L. $15 \mathrm{~cm}$, W.n/a,

H. $18 \mathrm{~cm}$.

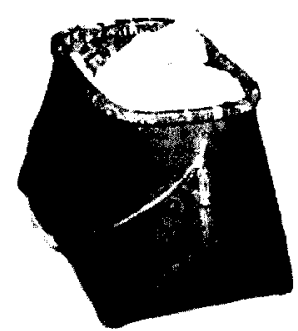

CMC III L 86, view 1

Algonquin

Maniwaki

F.G. Speck

1913

L. $28 \mathrm{~cm}, W .17 \mathrm{~cm}$

H. $18 \mathrm{~cm}$.

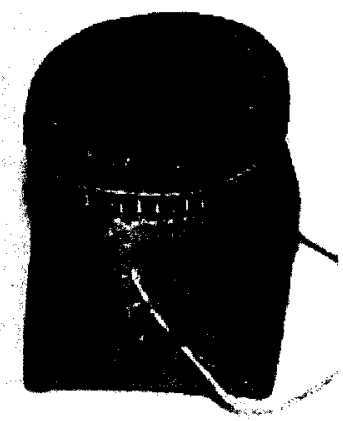

CMC III L 54

Algonquin

Maniwaki

E. Sapir

1912

$19 \mathrm{~cm}, W .12 \mathrm{~cm}$,

H. $12 \mathrm{~cm}$.

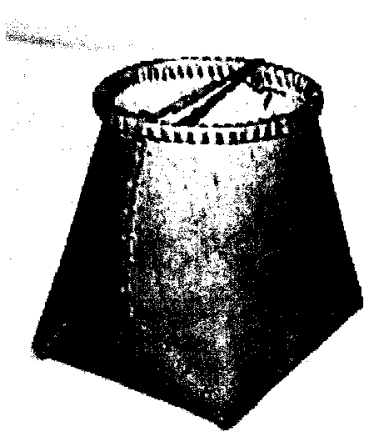

CMC III L 57

Algonquin

Maniwaki

E. Sapir

1912

L. $16 \mathrm{~cm}, W .14 \mathrm{~cm}$,

$\mathrm{H} .17 \mathrm{~cm}$.

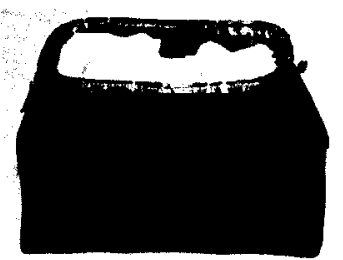

CMC III L 86, view 2

Algonquin

Maniwaki

F.G. Speck

1913

L. $28 \mathrm{~cm}, W .17 \mathrm{~cm}$,

H. $18 \mathrm{~cm}$ 


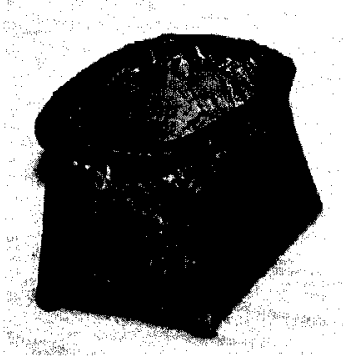

CMC III L 87

Algonquin

Maniwaki

F.G. Speck

1913

L. $14 \mathrm{~cm}, W .9 \mathrm{~cm}$,

H. $9 \mathrm{~cm}$.

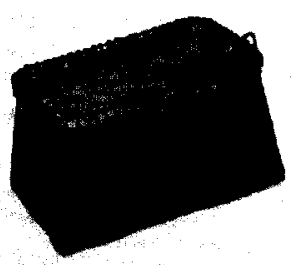

CMC III L 109, view 1

Algonquin

Temiskaming

F.G. Speck

1913

L. $12 \mathrm{~cm}$, W.n/a,

$H .10 \mathrm{~cm}$.

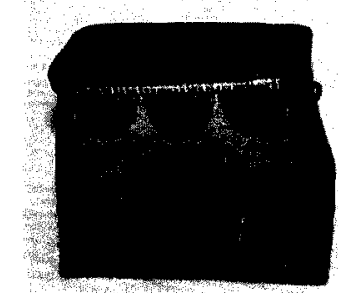

CMC III L 103, view 1

Algonquin

Lake Temiskaming

F.G. Speck

1913

L. $39 \mathrm{~cm}, W .37 \mathrm{~cm}$,

H. $25 \mathrm{~cm}$.

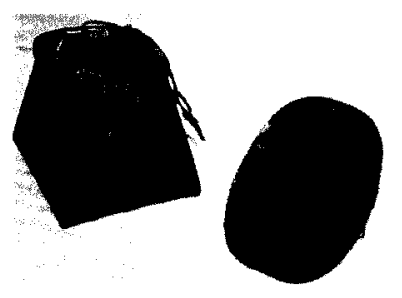

CMC III L 98

Algonquin

Lake Temiskaming

F.G. Speck

1913

L. $26 \mathrm{~cm}, W .19 \mathrm{~cm}$,

$\mathrm{H} .19 \mathrm{~cm}$.

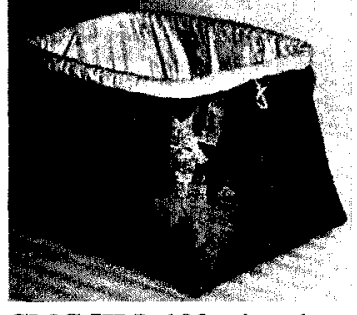

CMC III L 102, view 1

Algonquin

Lake Temiskaming

F.G. Speck

1913

$\mathrm{L} .39 \mathrm{~cm}, W .37 \mathrm{~cm}$,

$\mathrm{H} .26 \mathrm{~cm}$.

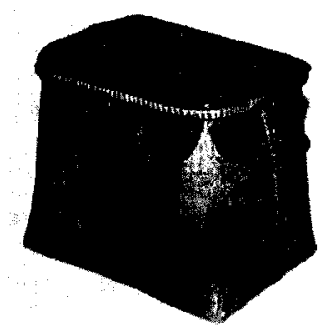

CMC III L 103, view 2

Algonquin

Lake Temiskaming

F.G. Speck

1913

L. $39 \mathrm{~cm}, W .37 \mathrm{~cm}$,

$\mathrm{H} .25 \mathrm{~cm}$.

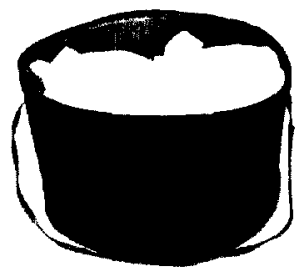

CMC III L 99

Algonquin

Lake Temiskaming

F.G. Speck

1913

H. $12 \mathrm{~cm}$, Dia. $18 \mathrm{~cm}$.

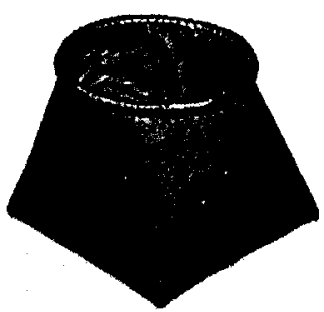

III L 110

Lake Temiskaming

F.G. Speck

1913

L. $12 \mathrm{~cm}$, W.n/a,

$\mathrm{H} .10 \mathrm{~cm}$.

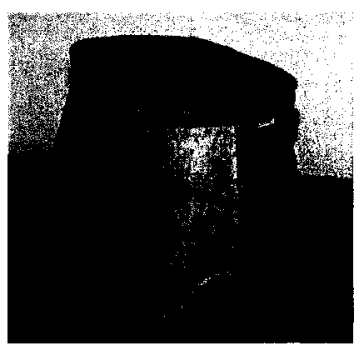

CMC III L 113

Algonquin

Lake Temiskaming

F.G. Speck

1913

$\mathrm{n} / \mathrm{a}$ 


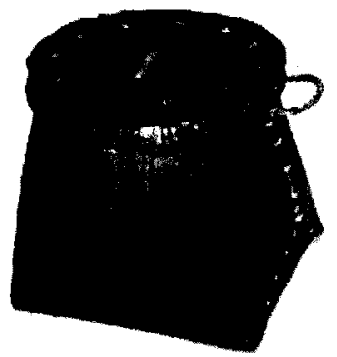

CMC III L 106

Algonquin

Lake Temiscaming

F.G. Speck

1913

L. $12 \mathrm{~cm}, \mathrm{~W} . \mathrm{n} / \mathrm{a}$,

$\mathrm{H} .12 \mathrm{~cm}$.
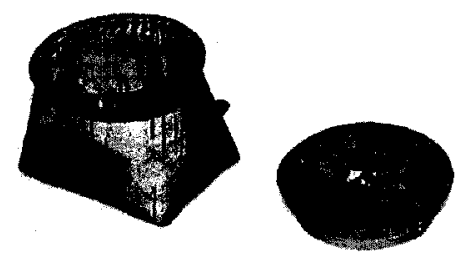

CMC III L 100

Algonquin

Lake Temiskaming

F.G. Speck

1913

L. $11 \mathrm{~cm}, W .9 \mathrm{~cm}$,

$\mathrm{H} .10 \mathrm{~cm}$.

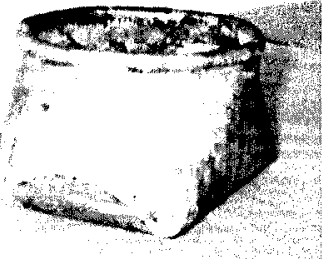

\section{CMC III L Ill}

Algonquin

Lake Temiskaming

F.G. Speck

1913

$\mathrm{n} / \mathrm{a}$

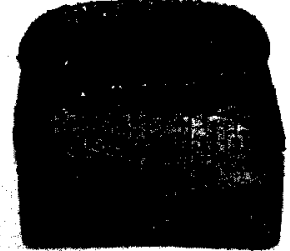

CMC III L 108, view 1

Algonquin

Lake Temiscaming

F.G. Speck

1912

n/a

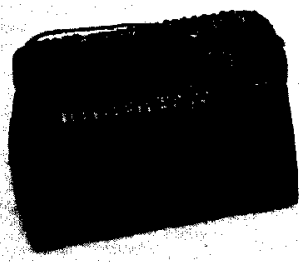

CMC III L 109, view 2

Algonquin

Temiskaming

F.G. Speck

1913

L. $12 \mathrm{~cm}$, W.n/a,

H. $10 \mathrm{~cm}$

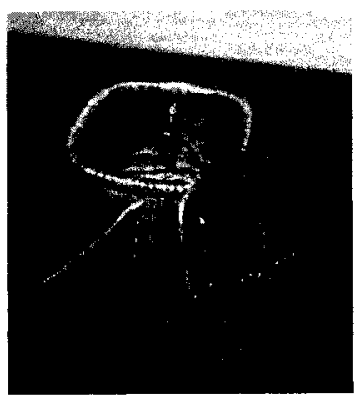

CMC III L 112

Algonquin

Lake Temiskaming

F.G. Speck

1913

L. $19 \mathrm{~cm}, W .13 \mathrm{~cm}, H .13 \mathrm{~cm}$

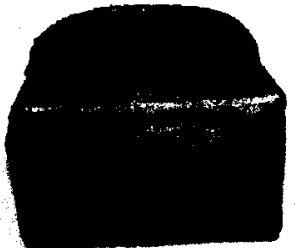

CMC III L 108, view 2

Algonquin

Lake Temiscaming

F.G. Speck

1912

$\mathrm{n} / \mathrm{a}$

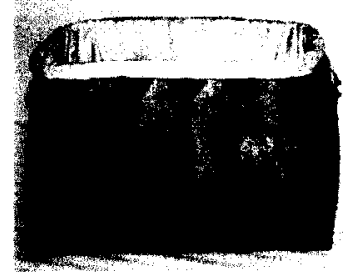

CMC III L 102, view 2

Algonquin

Lake Temiskaming

F.G. Speck

1913

L. $39 \mathrm{~cm}, W .37 \mathrm{~cm}$,

H. $26 \mathrm{~cm}$

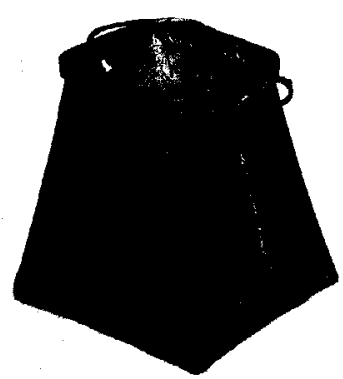

CMC III L 105

Algonquin

Lake Temiskaming

F.G. Speck

1913

L. $18 \mathrm{~cm}, W .15 \mathrm{~cm}$,

$\mathrm{H} .18 \mathrm{~cm}$. 


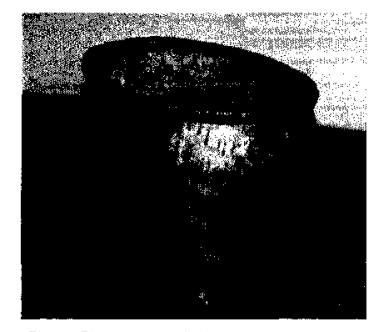

CMC III L 115

Algonquin

Lake Temiskaming

F.G. Speck

1913

L. $38 \mathrm{~cm}, W .23 \mathrm{~cm}$,

H. $20 . \mathrm{cm}$

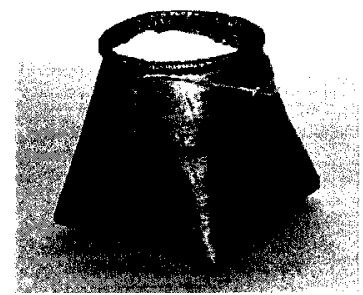

CMC III L 116

Algonquin

Lake Temiskaming

F.G. Speck

1913

L. $20 \mathrm{~cm}, \mathrm{~W} . \mathrm{n} / \mathrm{a}$

H. $18 \mathrm{~cm}$.

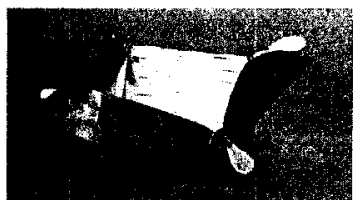

CMC III L 117

Algonquin

Lake Temiscaming F.G. Speck

1913

L. $15 \mathrm{~cm}, W .13 \mathrm{~cm}$,

$\mathrm{H} .5 \mathrm{~cm}$. 


\section{Montagnais Birch Bark Baskets}

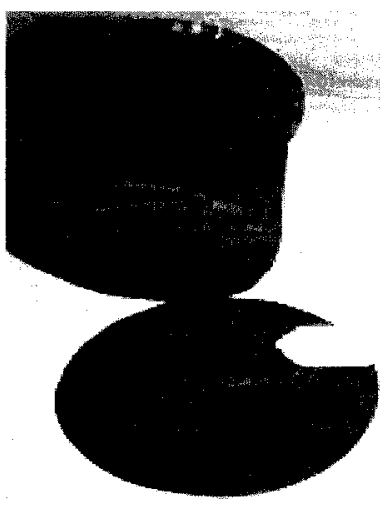

CMC III C 17

Montagnais

Pointe Bleue

Edward Sapir

1911

H. $20 \mathrm{~cm}$, Dia. $22 \mathrm{~cm}$.

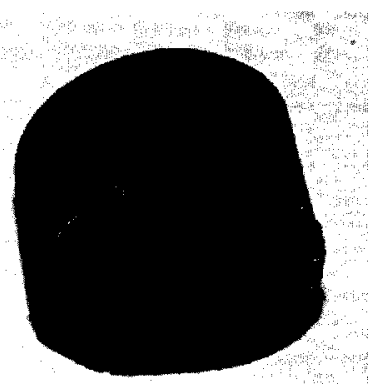

CMC III C 157

Montagnais

Lac St. Jean

Frank G. Speck

1912

H. $3 \mathrm{~cm}$, Dia. $5 \mathrm{~cm}$

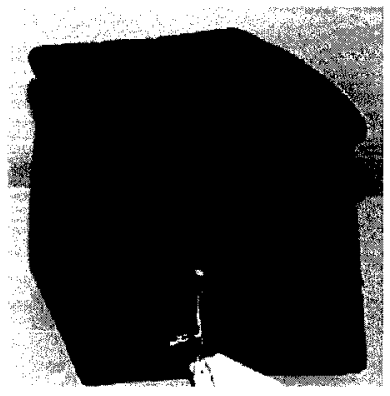

CMC III C 167

Montagnais

Lake St. John

Frank G. Speck

1907-08

L. $29 \mathrm{~cm}$, W. 20 ,

H. $20 . \mathrm{cm}$

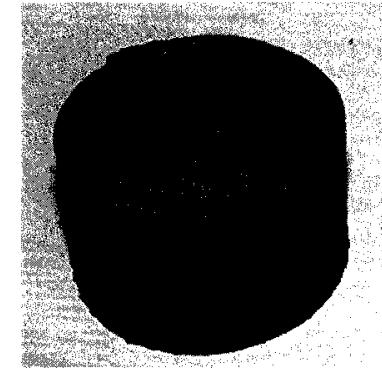

\section{CMC III C 155}

Montagnais

Lac St. Jean

Frank G. Speck

1912

H. $5 \mathrm{~cm}$, Dia. $8 \mathrm{~cm}$.

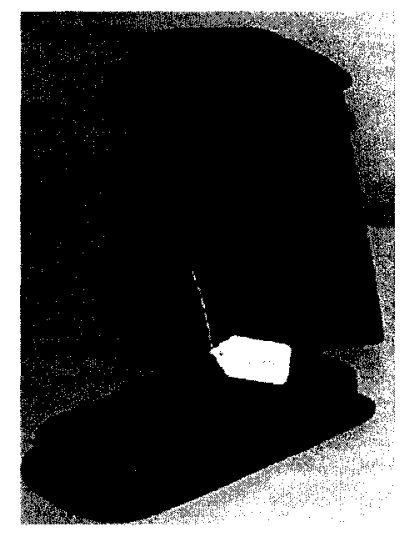

CMC III C 161

Montagnais

Lac St. Jean

Frank G. Speck

1912

$L .33 \mathrm{~cm}, W .22 \mathrm{~cm}$,

$\mathrm{H} .27 \mathrm{~cm}$.

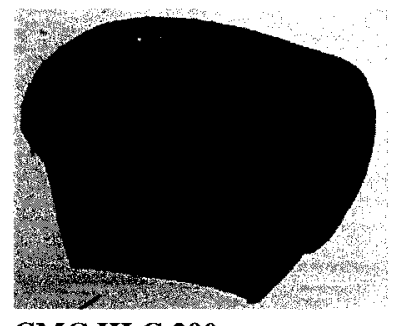

CMC III C 200

Montagnais

Lac St. Jean

Frank G. Speck

1912

L. $15 \mathrm{~cm}, W .14 \mathrm{~cm}$,

H. $6 \mathrm{~cm}$.

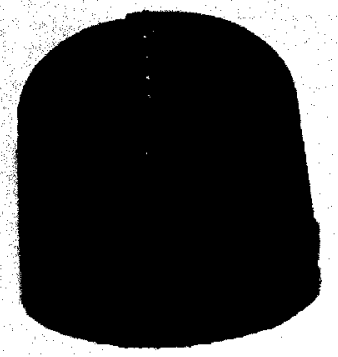

CMC III C 156

Montagnais

Lac St. Jean

Frank G. Speck

1912

H. $5 \mathrm{~cm}$, Dia. $7 \mathrm{~cm}$.

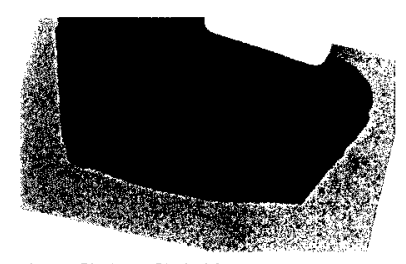

CMC III C 163

Montagnais

Lake St. John

Frank G. Speck

1912

L. 12.2, W.11.9cm,

H. $5 \mathrm{~cm}$.

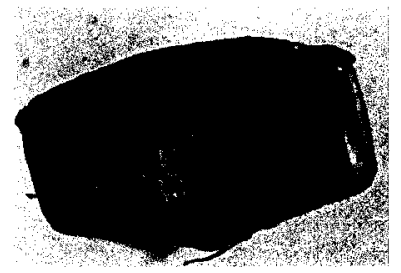

CMC III C 201

Montagnais

Lac St. Jean

Frank G. Speck

1912

L. $11 \mathrm{~cm}, W .7 \mathrm{~cm}$,

$\mathrm{H} .4 \mathrm{~cm}$. 


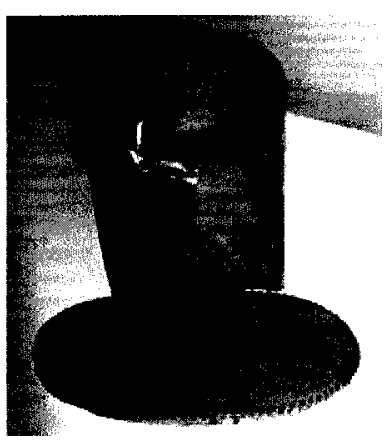

CMC III C 432

Montagnais

Lac St. John

Frank G. Speck

1913

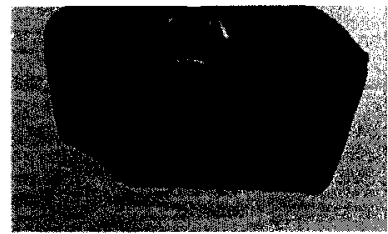

CMC III C 436

Montagnais

Lac St. Jean

F.G. Speck

April 1913

L. $12 \mathrm{~cm}, W .12 \mathrm{~cm}$.

$H .5 \mathrm{~cm}$.

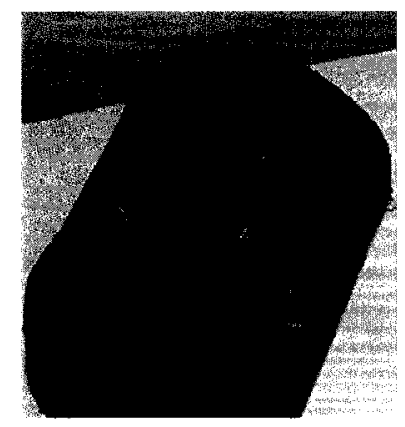

CMC III C 450

Montagnais

Lac St. Jean

Frank G. Speck

1913

H. $24 \mathrm{~cm}$, Dia. $16 \mathrm{~cm}$.

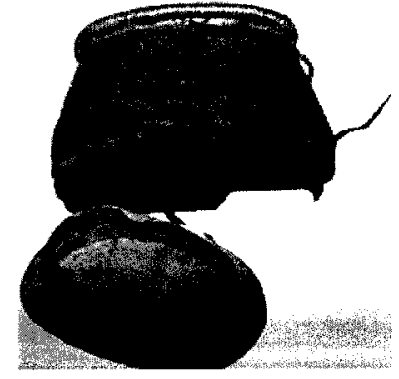

CMC III C 433

Montagnais

Lac St. Jean

Frank G. Speck

1913

L. $19 \mathrm{~cm}, W .11 \mathrm{~cm}$,

H. $13 \mathrm{~cm}$.

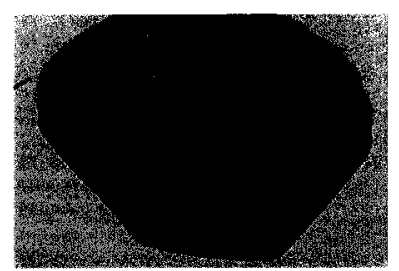

\section{CMC III C 440}

Montagnais

Lac St. Jean

Frank G. Speck

L. $14 \mathrm{~cm}, W .17 \mathrm{~cm}$,

$\mathrm{H} .7 \mathrm{~cm}$.

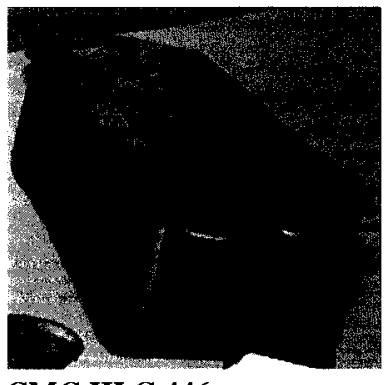

CMC III C 446

Montagnais

Lac St. Jean

Frank G. Speck

1913

L. $23 \mathrm{~cm}, W .13 \mathrm{~cm}$.

$H .8 \mathrm{~cm}$.

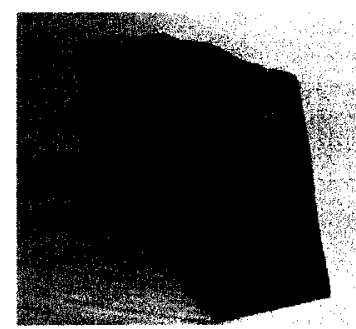

CMC III C 434

Montgnais

Lac St. Jean

Frank G. Speck

1913

L. $53 \mathrm{~cm}$, W.n/a.

H. $27 \mathrm{~cm}$

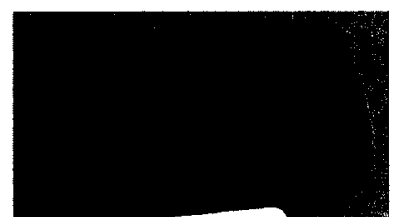

CMC III C 445

Montagnais

Lac St. Jean

Frank G. Speck

1913

L. $20 \mathrm{~cm}, W .15 \mathrm{~cm}$

H. $4 \mathrm{~cm}$.

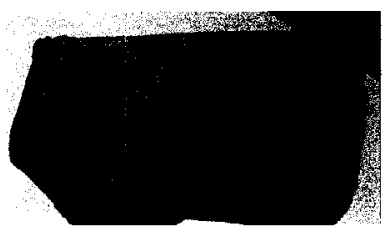

CMC III C 448

Montagnais

Lake St. John

F.G. Speck

1913

L. $25 \mathrm{~cm}, W .21 \mathrm{~cm}$

$\mathrm{H} .14 \mathrm{~cm}$. 


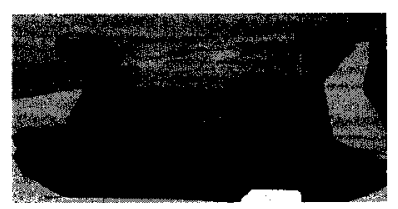

CMC III C 449

Montagnais

Lac St. Jean

F.G. Speck

1913

L. $39 \mathrm{~cm}, W .30 \mathrm{~cm}$,

$\mathrm{H} .10 \mathrm{~cm}$. 


\section{Appendix Four}

MASTER TABLE OF CARRIER AND ALGONQUIN/MONTAGNAIS BASKETRY 


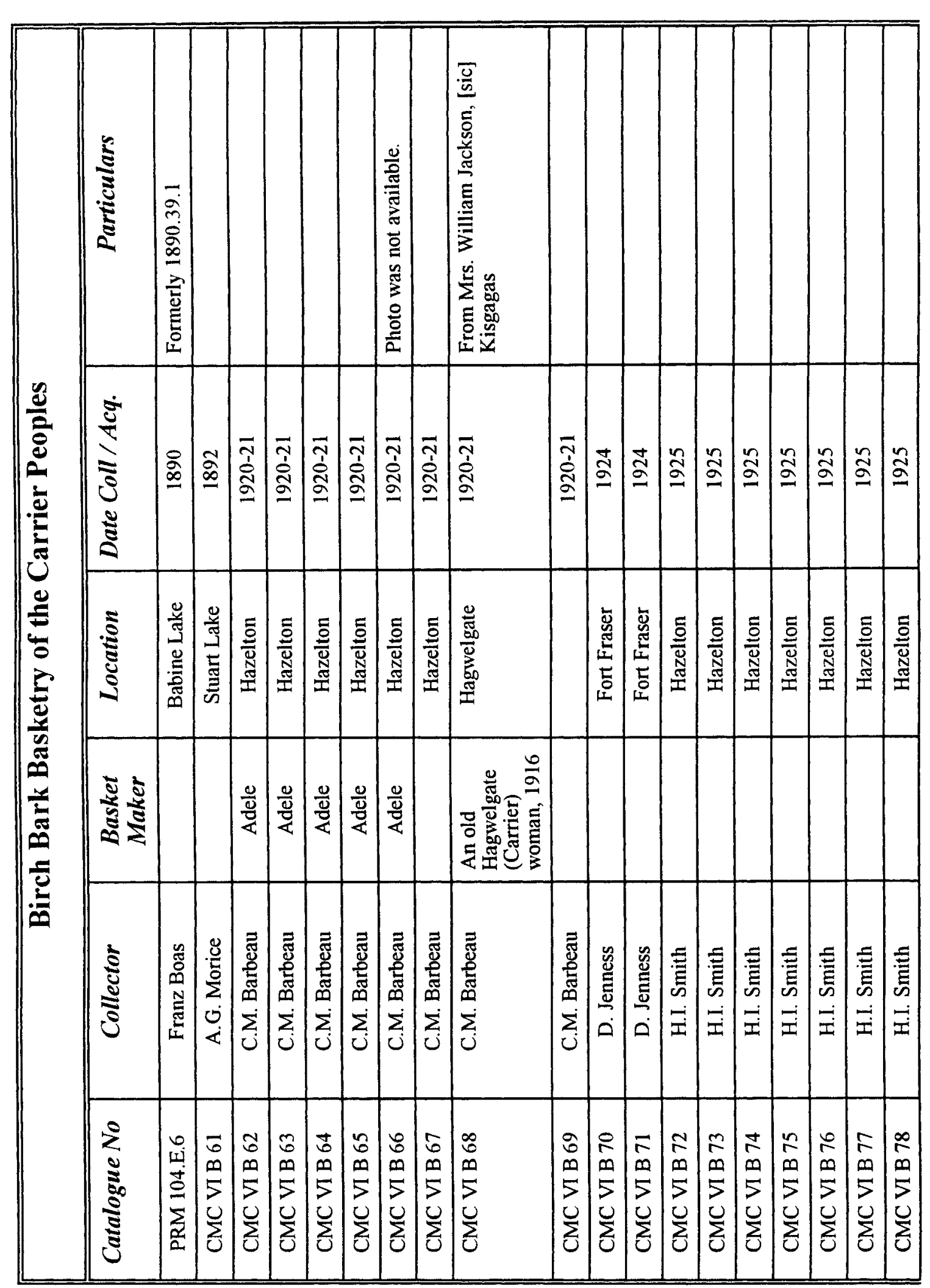




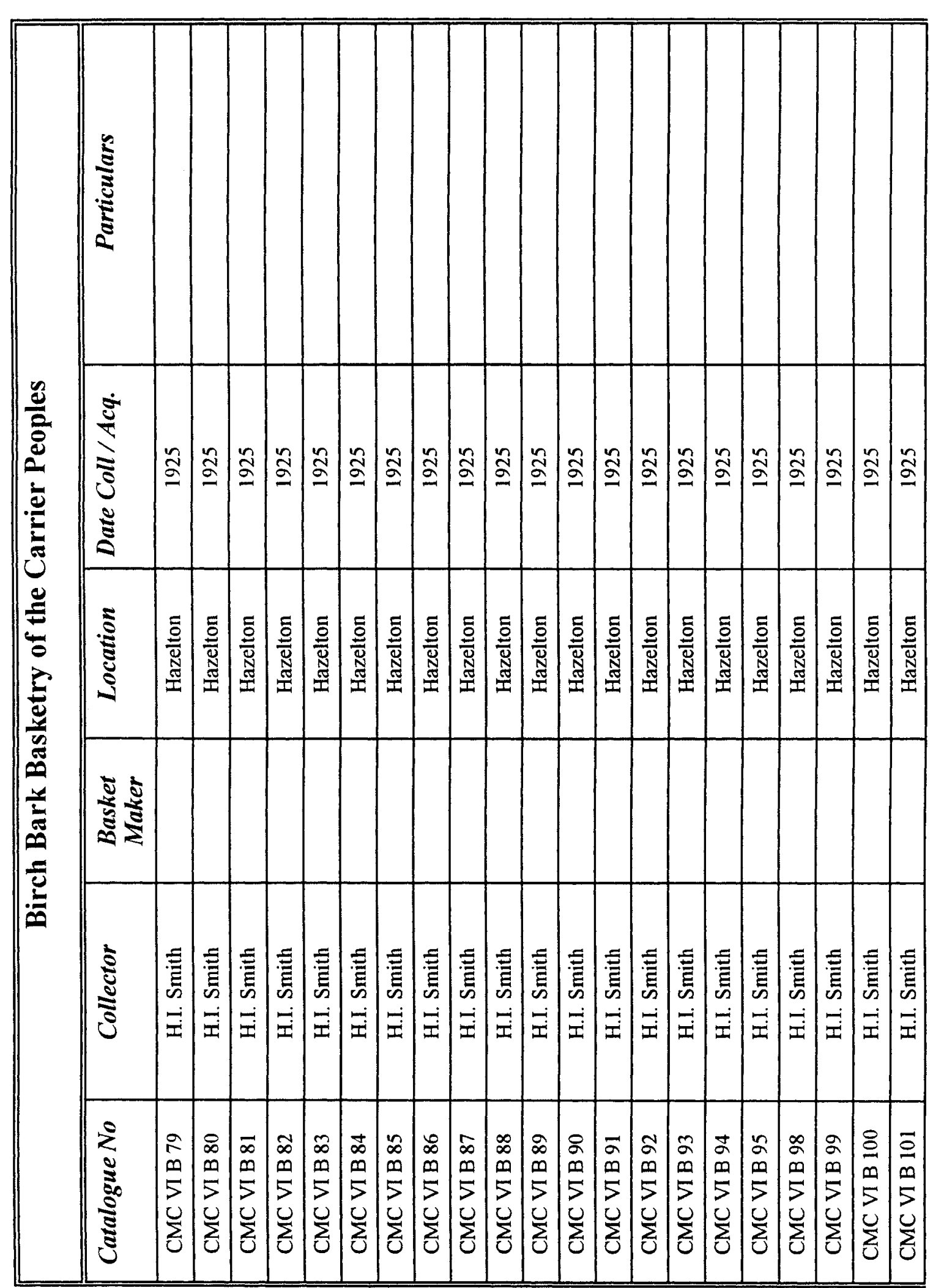

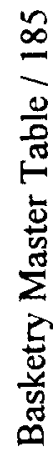




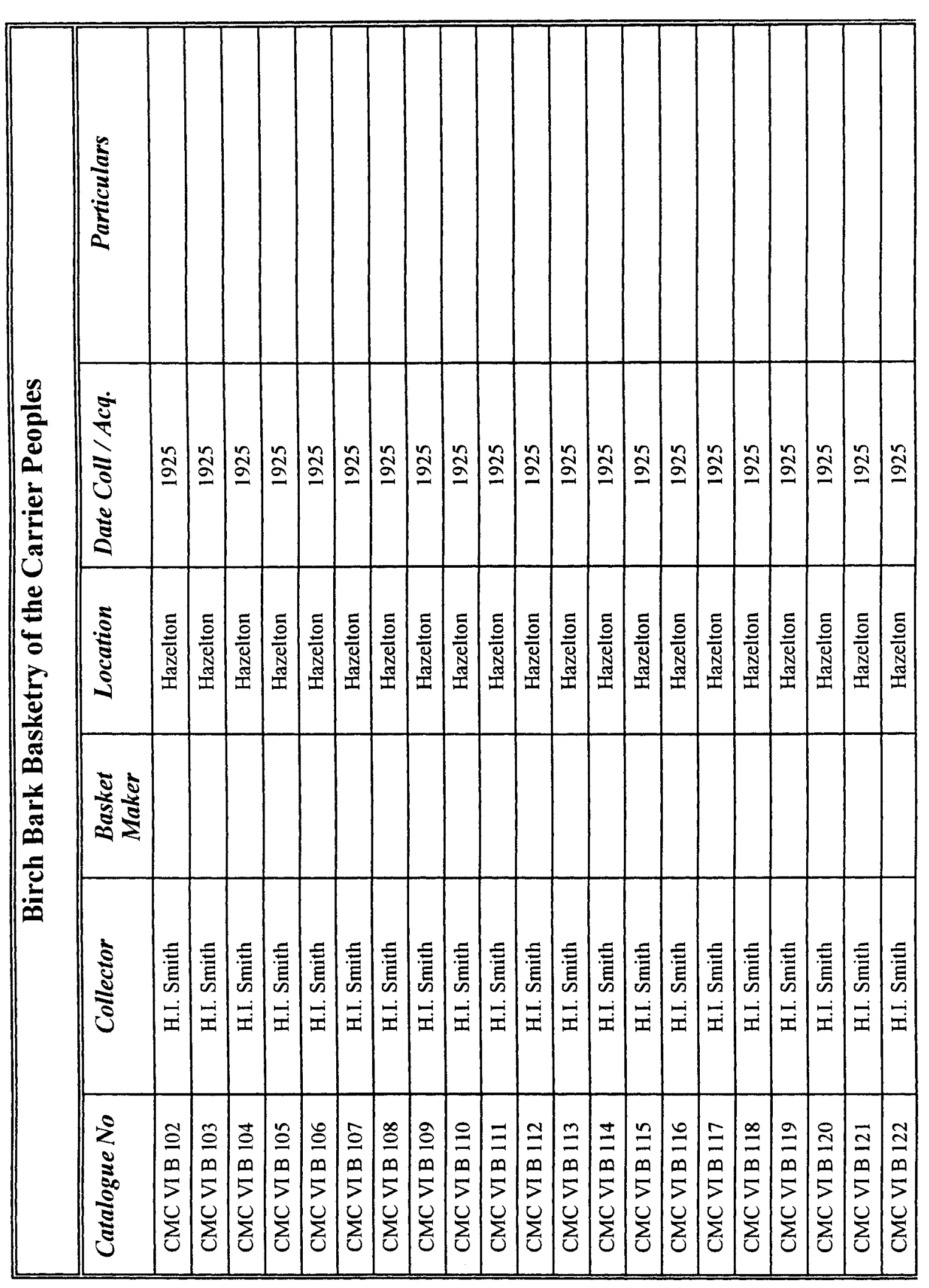




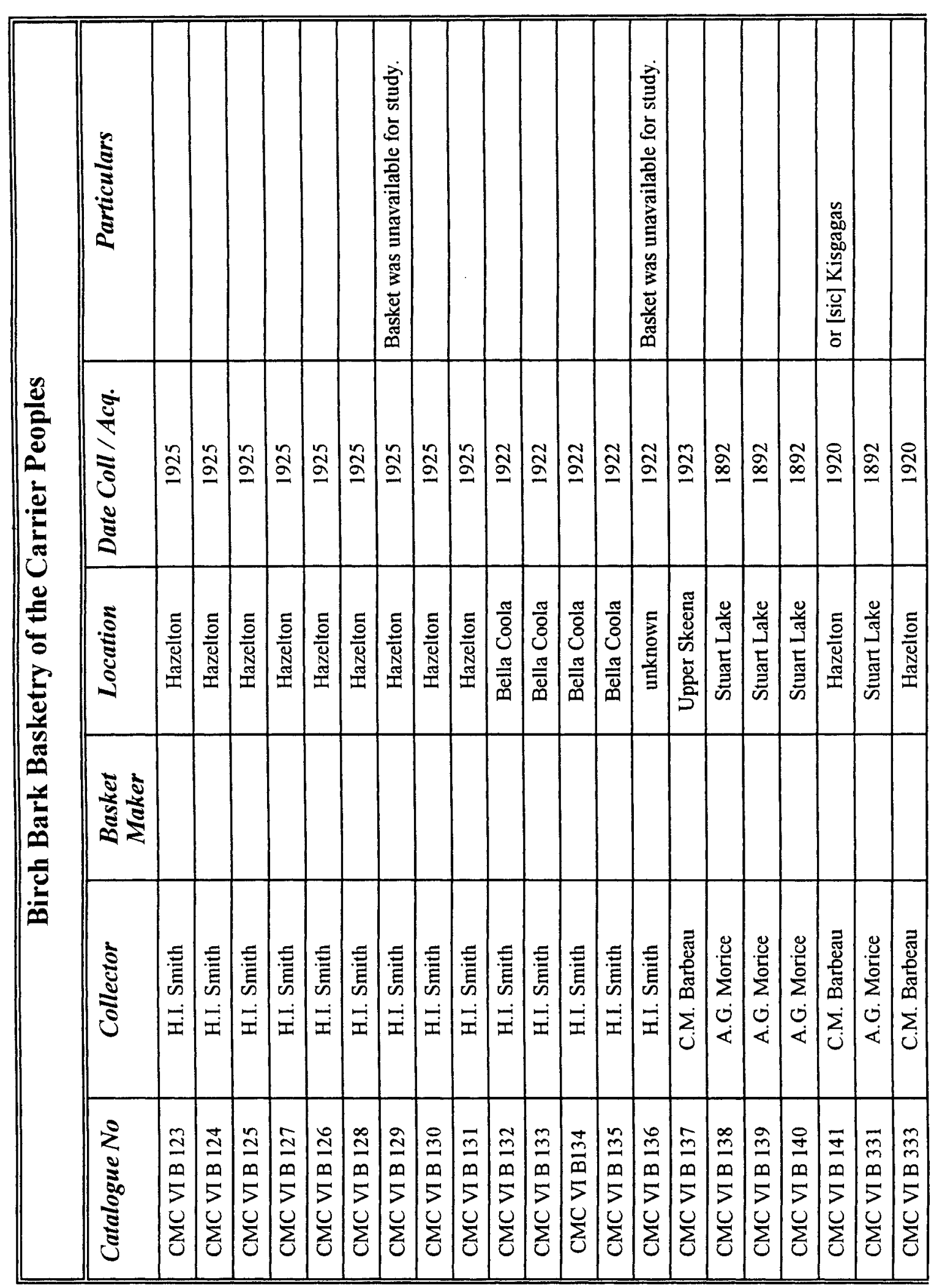




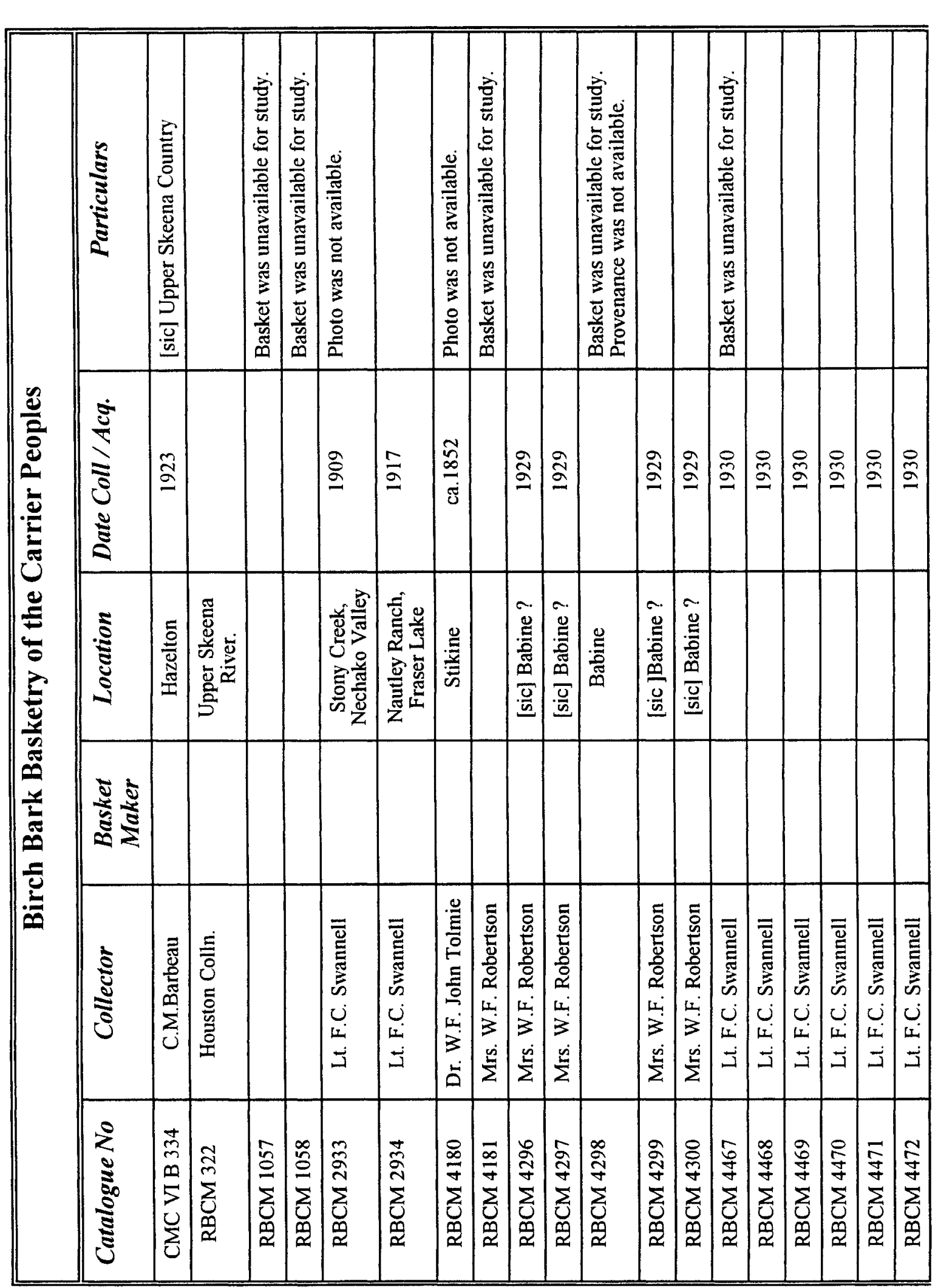

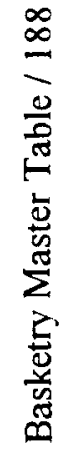




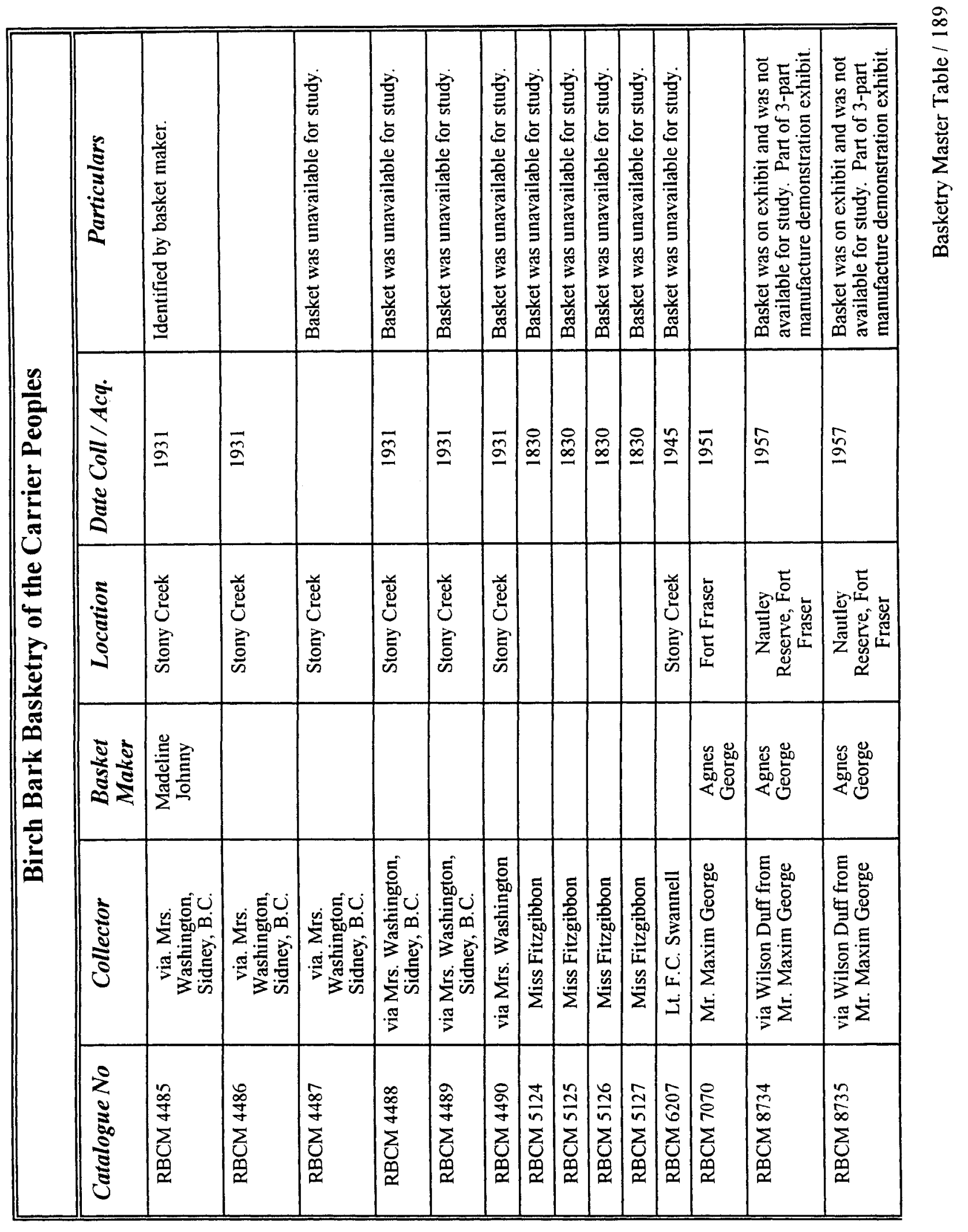




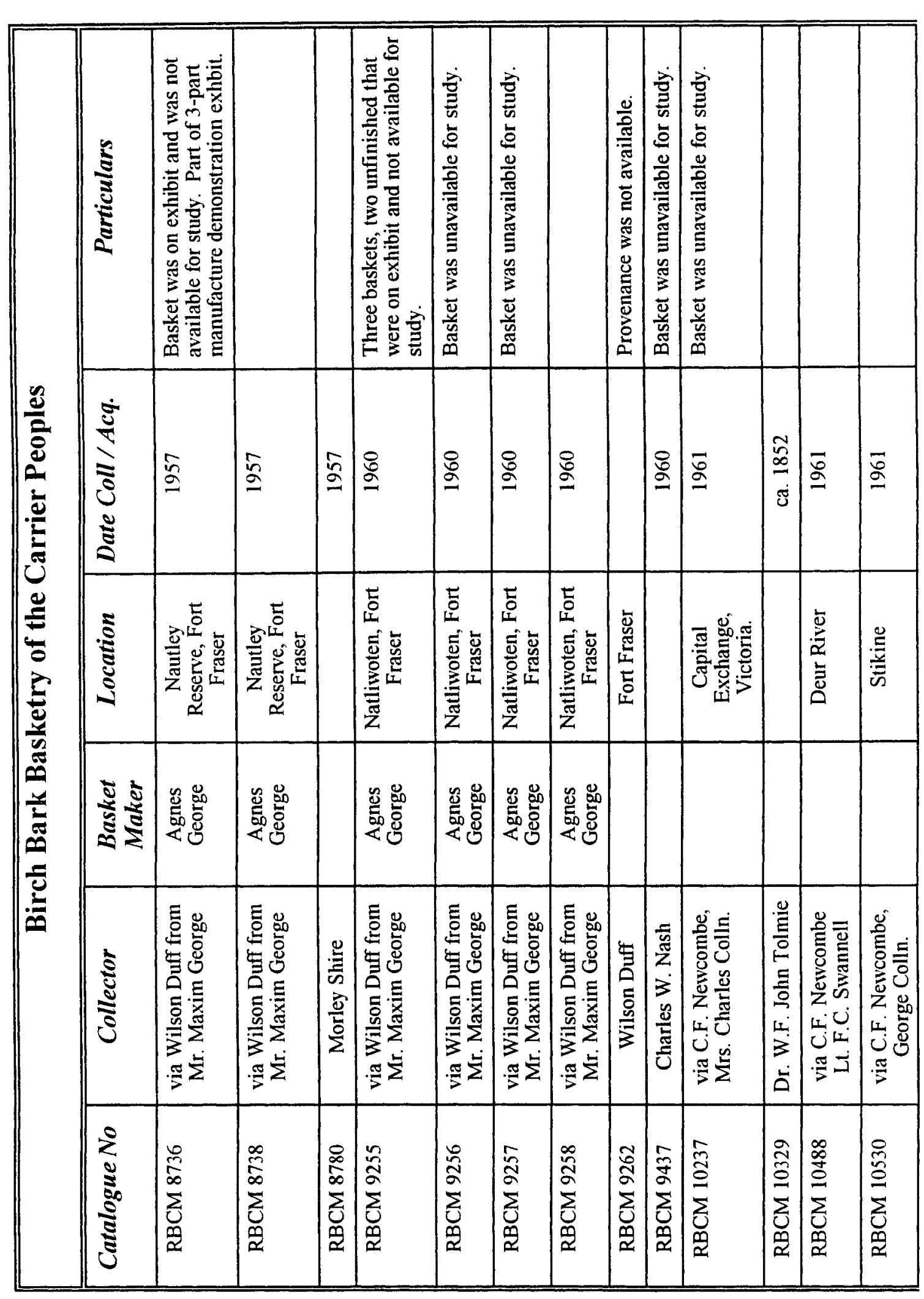

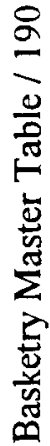




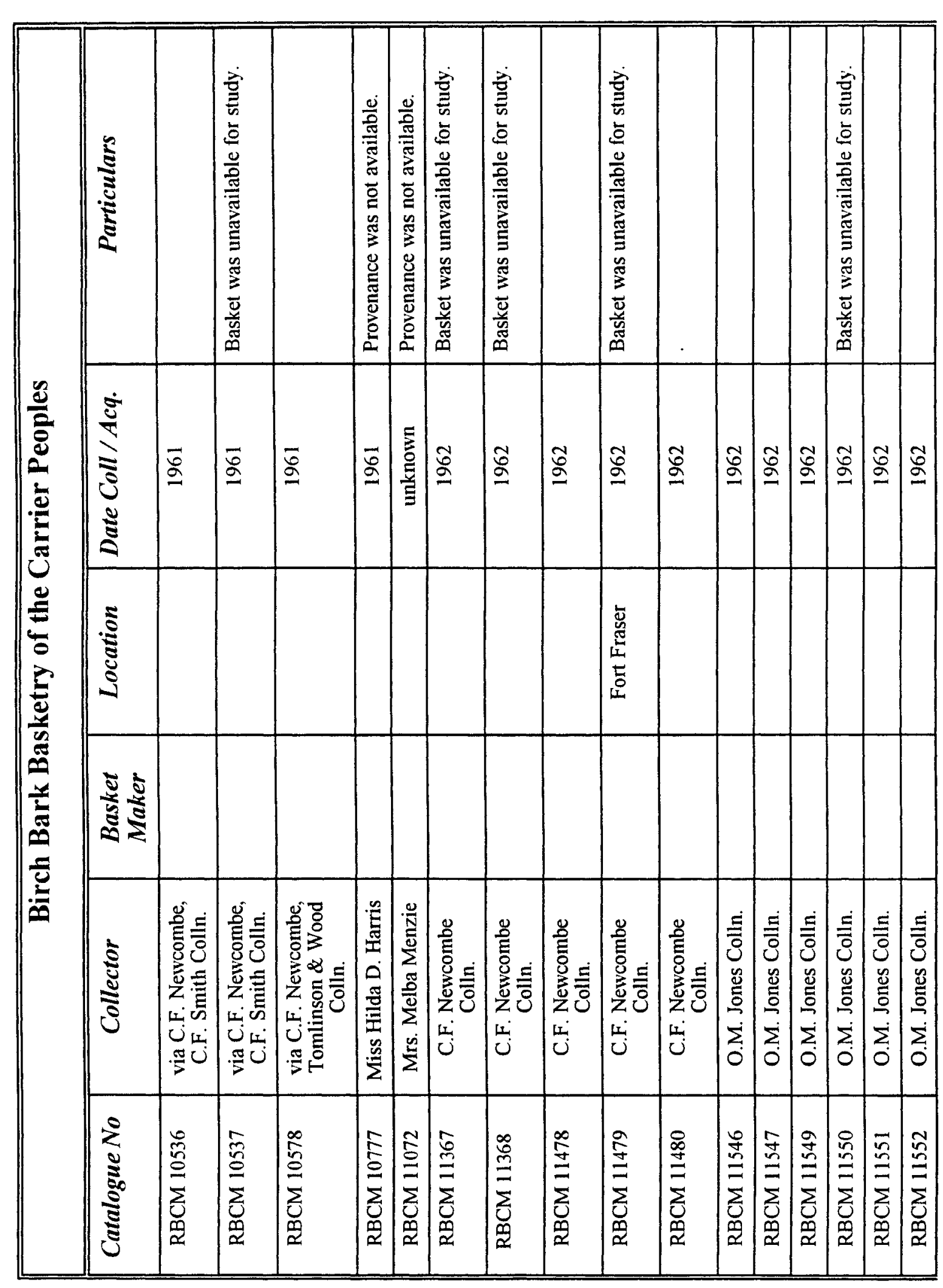

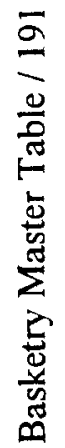




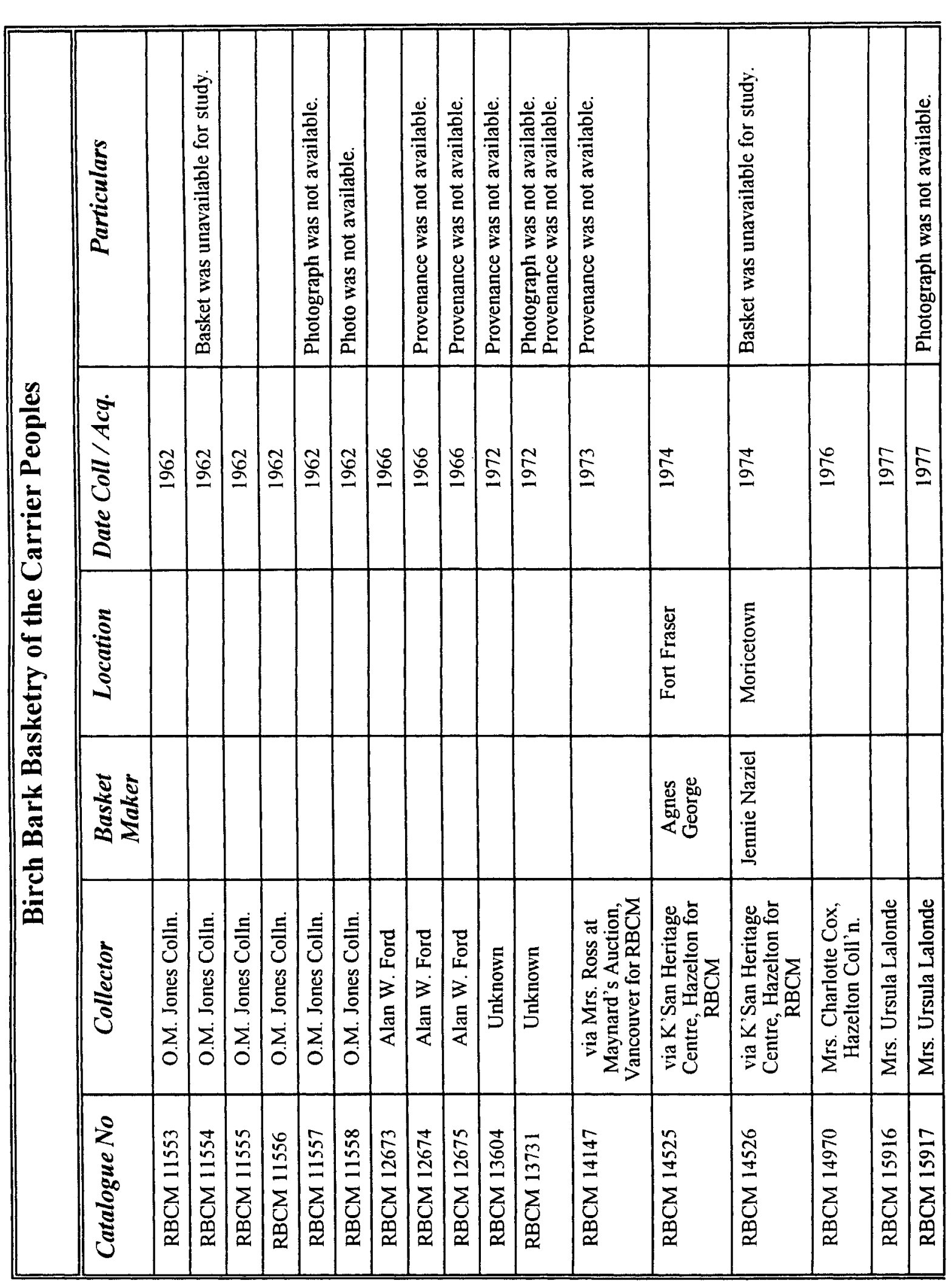




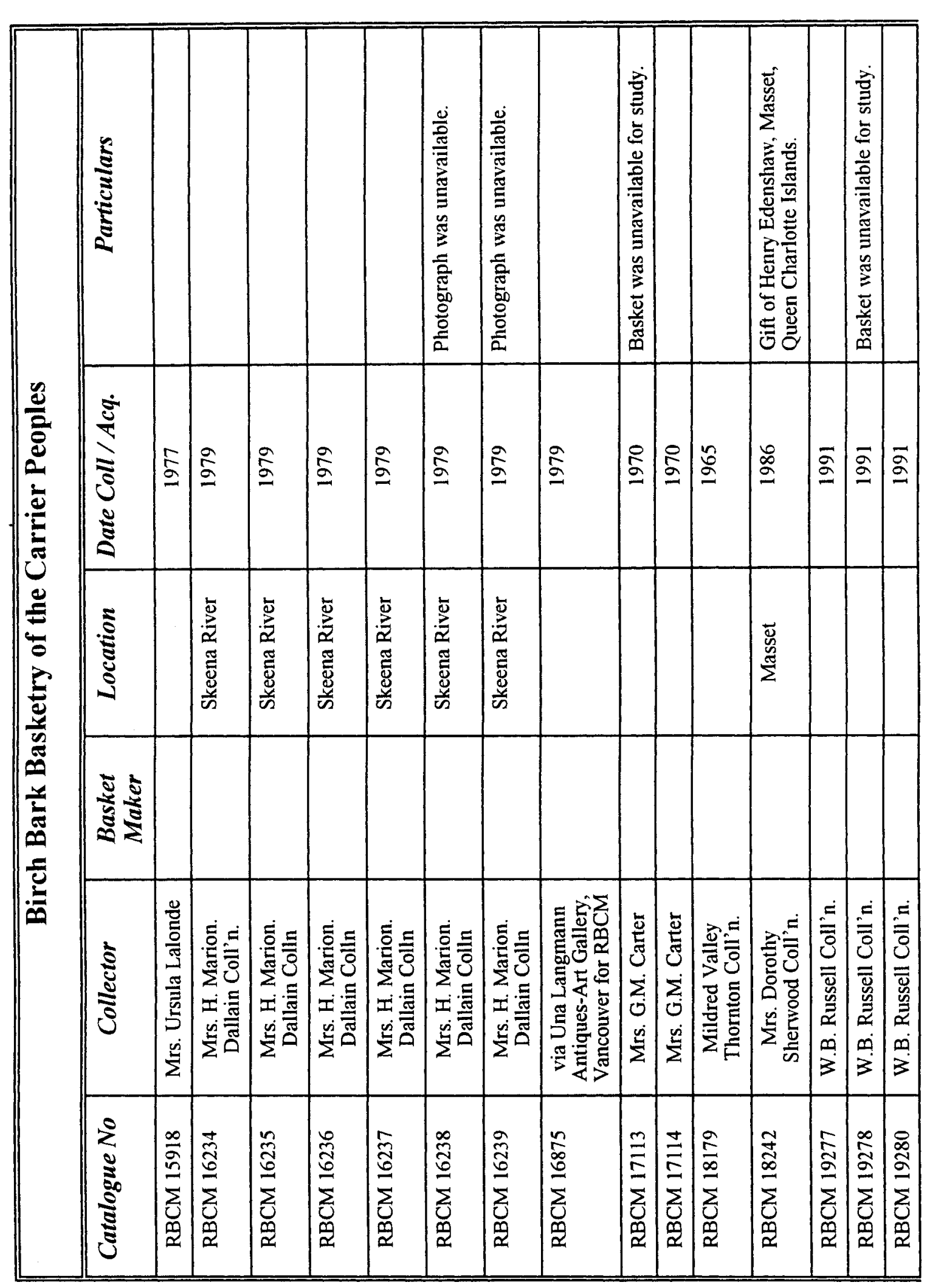



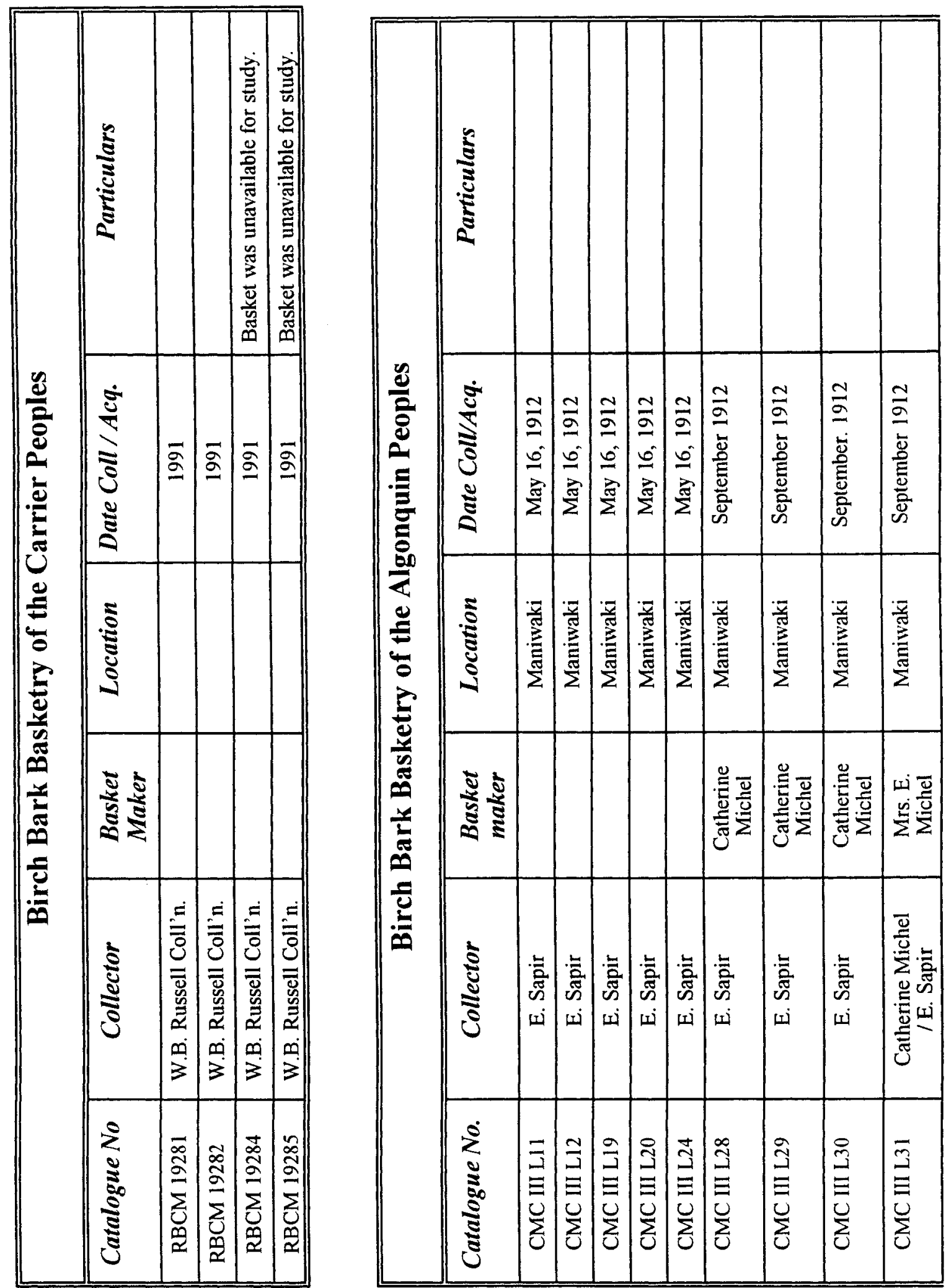

要 


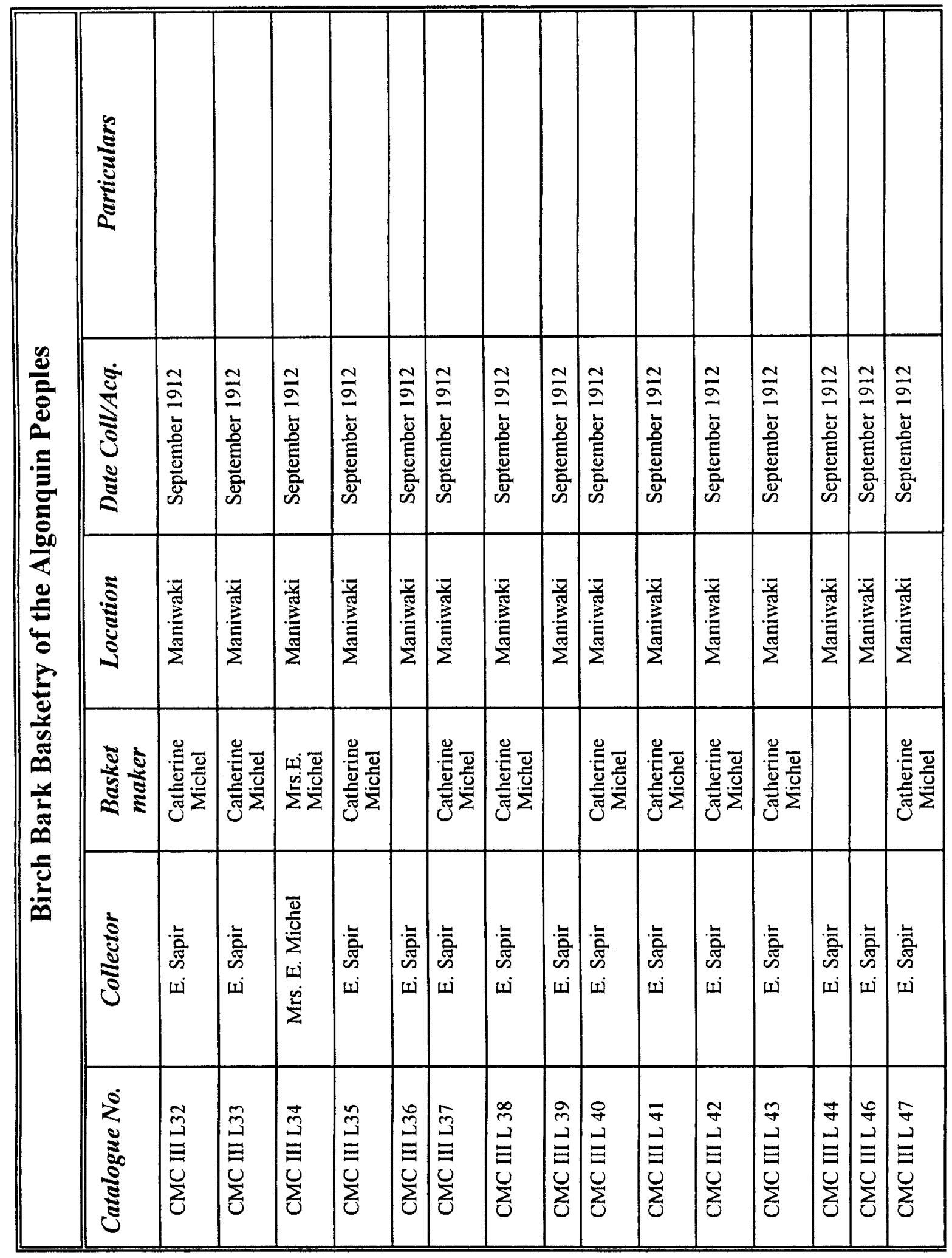

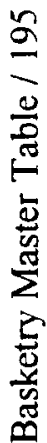




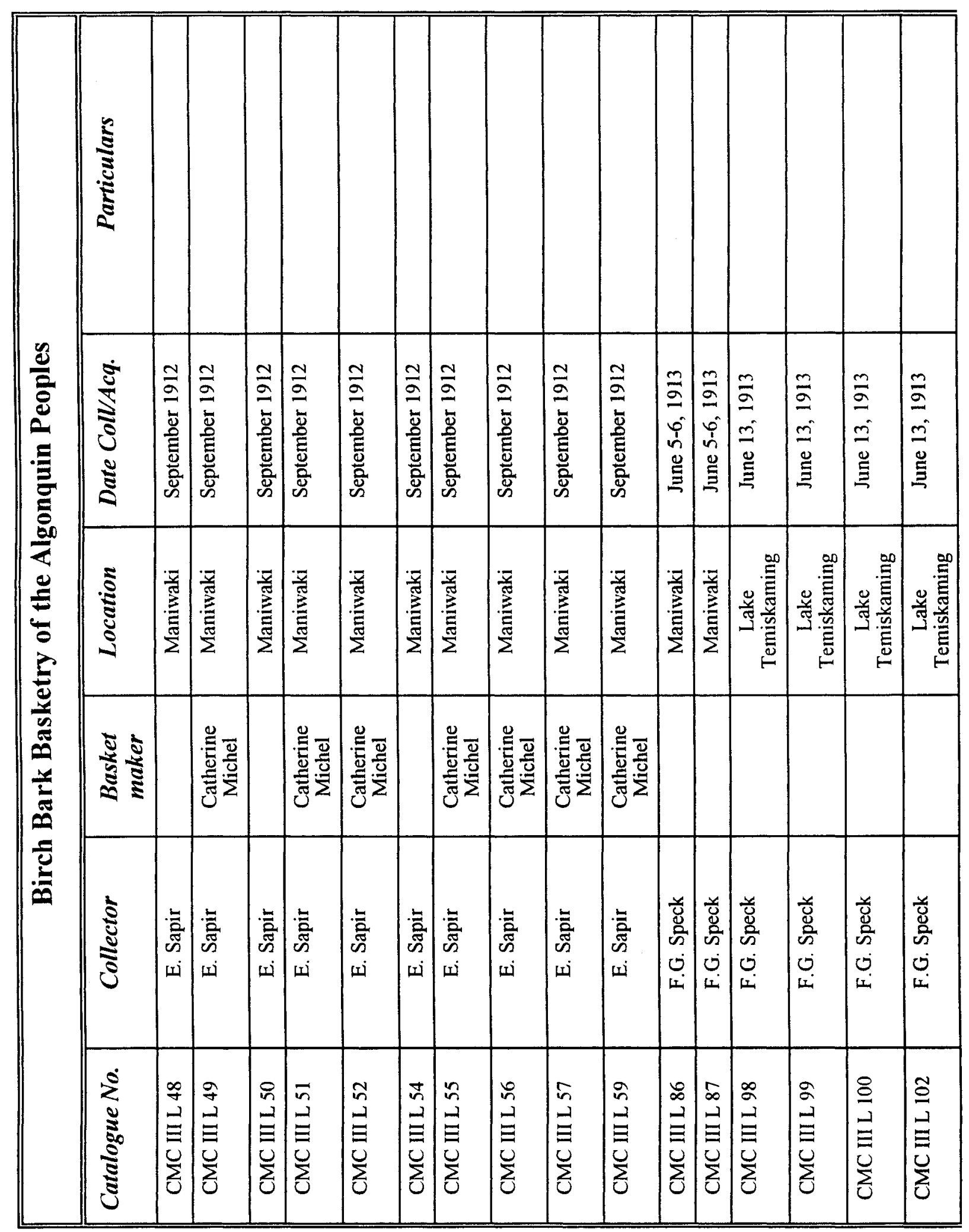

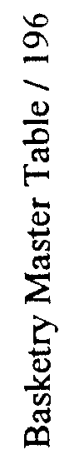




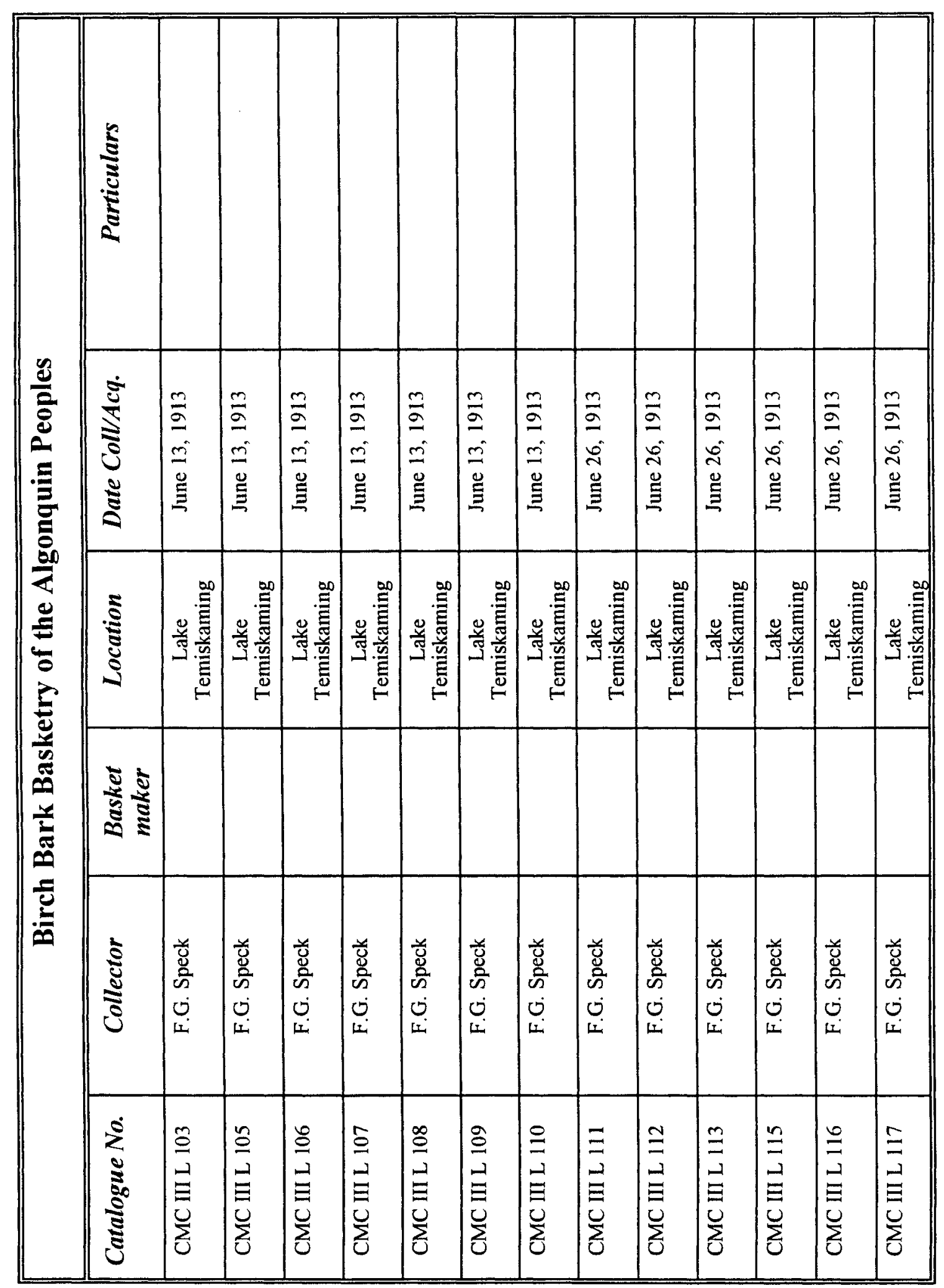

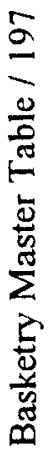




\begin{tabular}{|c|c|c|c|c|c|c|c|c|c|c|c|c|c|c|c|c|c|c|}
\hline \multirow{6}{*}{ 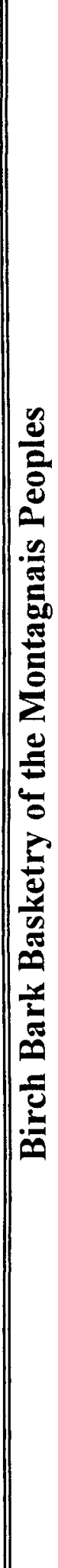 } & 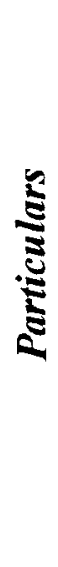 & 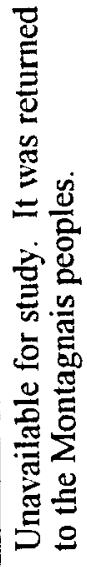 & & 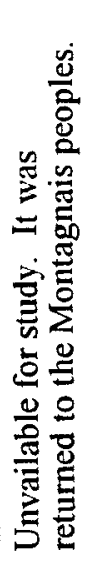 & 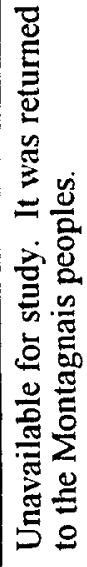 & & & & 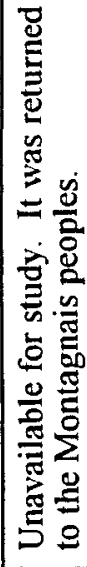 & 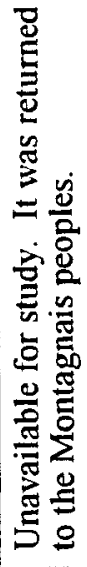 & & 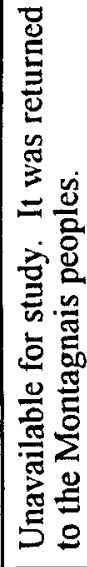 & & 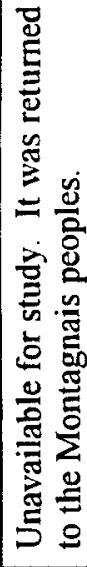 & 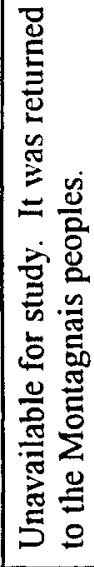 & 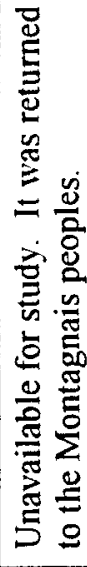 & & 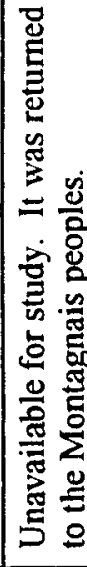 \\
\hline & 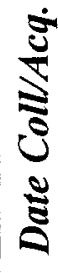 & $\bar{a}$ & $\bar{a}$ & $\bar{a}$ & $\bar{a}$ & $\frac{\mathfrak{a}}{\bar{a}}$ & $\frac{\sqrt{2}}{\frac{2}{2}}$ & $\frac{a}{2}$ & $\frac{\frac{N}{2}}{\frac{2}{2}}$ & $\frac{\frac{N}{2}}{\frac{\bar{E}}{\alpha}}$ & $\frac{\frac{a}{2}}{\frac{2}{2}}$ & $\frac{\frac{2}{a}}{\frac{2}{2}}$ & $\frac{a}{a}$ & $\frac{a}{\frac{a}{2}}$ & $\frac{a}{\frac{a}{2}}$ & $\frac{\frac{2}{2}}{\frac{\bar{E}}{2}}$ & $\begin{array}{l}\infty \\
0 \\
1 \\
\vdots \\
\vdots\end{array}$ & $\frac{\frac{\pi}{2}}{\frac{a}{2}}$ \\
\hline & 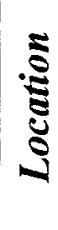 & 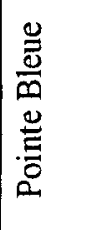 & 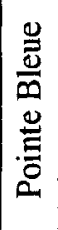 & 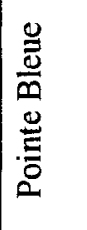 & 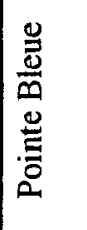 & 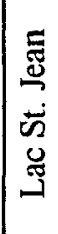 & 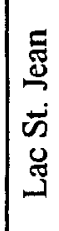 & 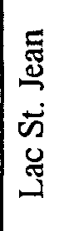 & 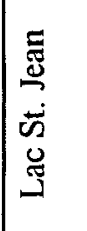 & 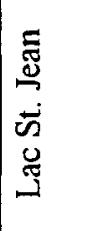 & 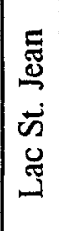 & 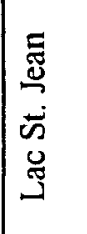 & 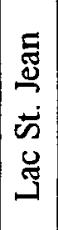 & 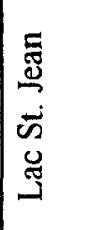 & 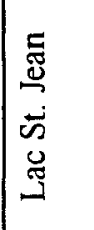 & 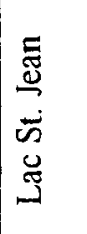 & 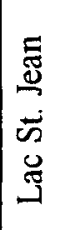 & 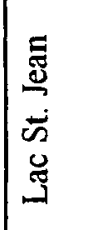 \\
\hline & 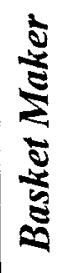 & & & & & & & & & & & & & & & & & \\
\hline & $\frac{\sqrt{5}}{\mathrm{~s}}$ & 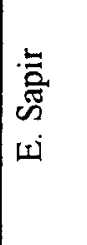 & 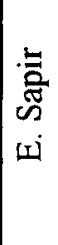 & 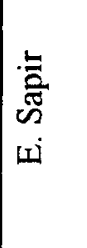 & 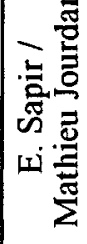 & 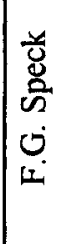 & 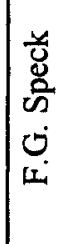 & 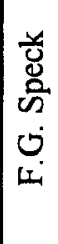 & 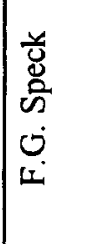 & 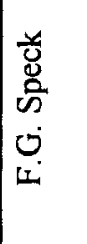 & 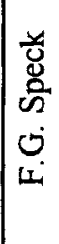 & 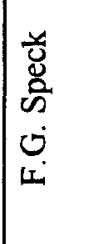 & 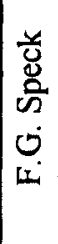 & 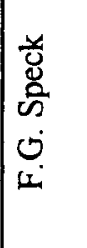 & 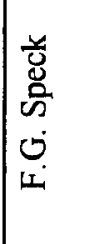 & 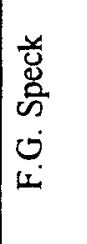 & 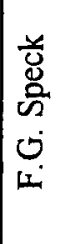 & 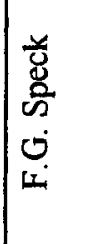 \\
\hline & 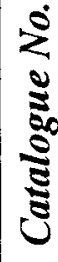 & $\begin{array}{l}n \\
u \\
\Xi \\
U \\
u\end{array}$ & $\begin{array}{l}\Xi \\
U \\
\Xi \\
\Xi \\
\dot{Z}\end{array}$ & $\begin{array}{l}\frac{\infty}{U} \\
\Xi \\
\underline{U}\end{array}$ & $\mid \begin{array}{l}\tilde{Z} \\
U \\
\Xi \\
\mathcal{Z}\end{array}$ & 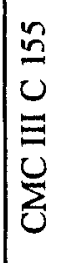 & 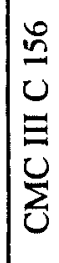 & $\begin{array}{l}n \\
0 \\
\vdots \\
\vdots \\
\vdots \\
z\end{array}$ & 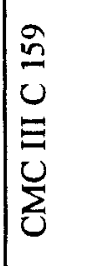 & 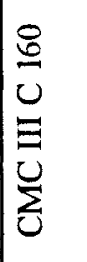 & $\begin{array}{l}\overline{0} \\
u \\
\Xi \\
U \\
己\end{array}$ & 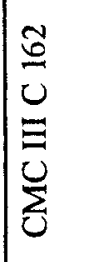 & 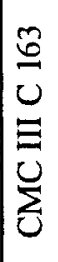 & 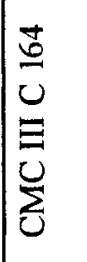 & 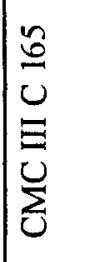 & $\begin{array}{l}0 \\
0 \\
U \\
\Xi \\
己 \\
己\end{array}$ & 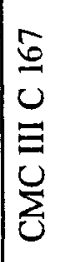 & 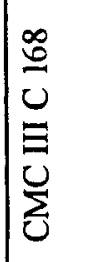 \\
\hline
\end{tabular}




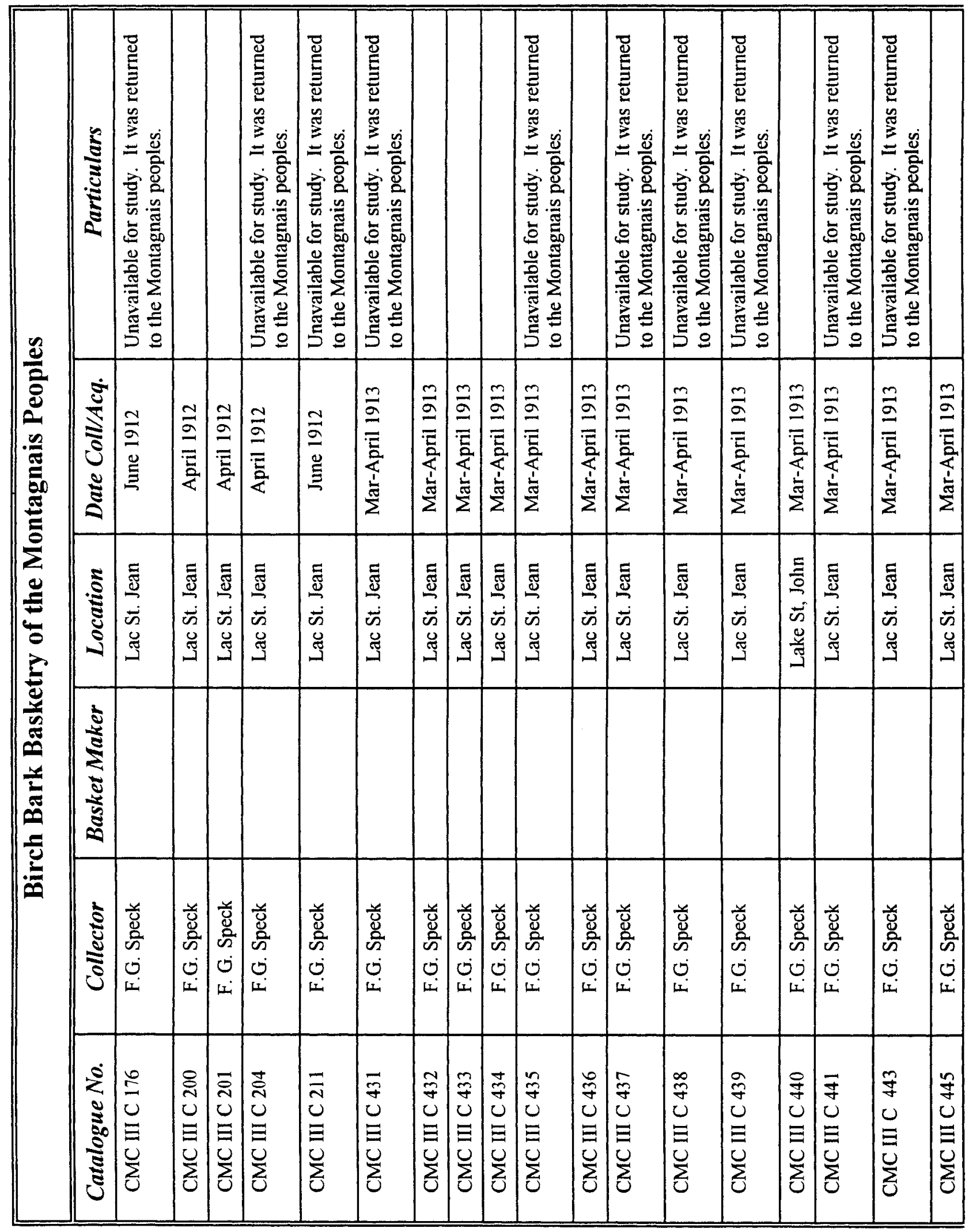




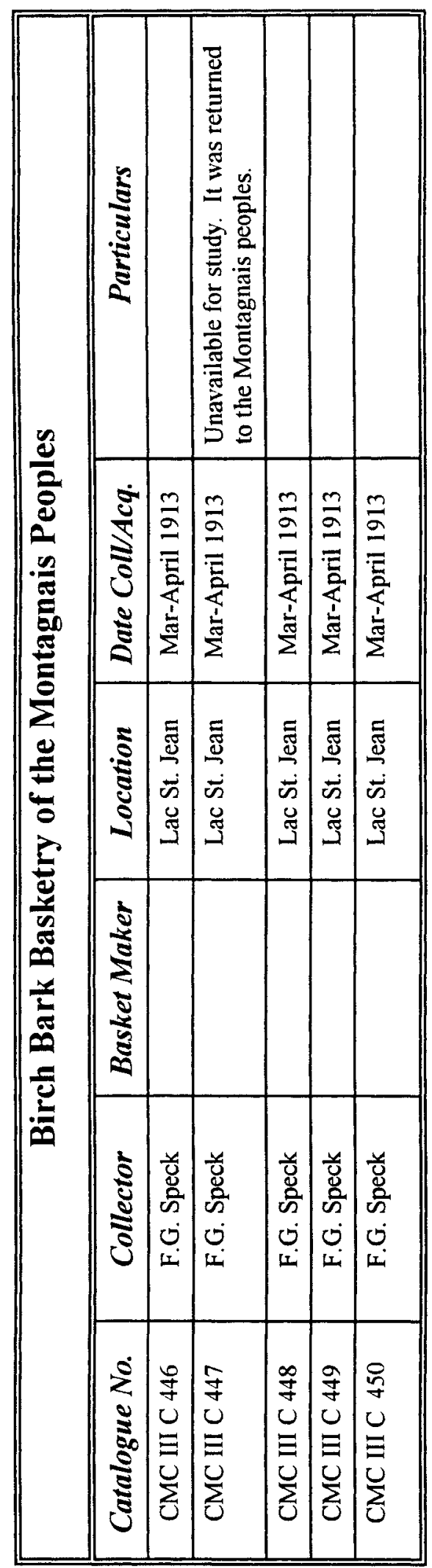

文 
Appendix Five

\section{ETHNOGRAPHIC NOTES}




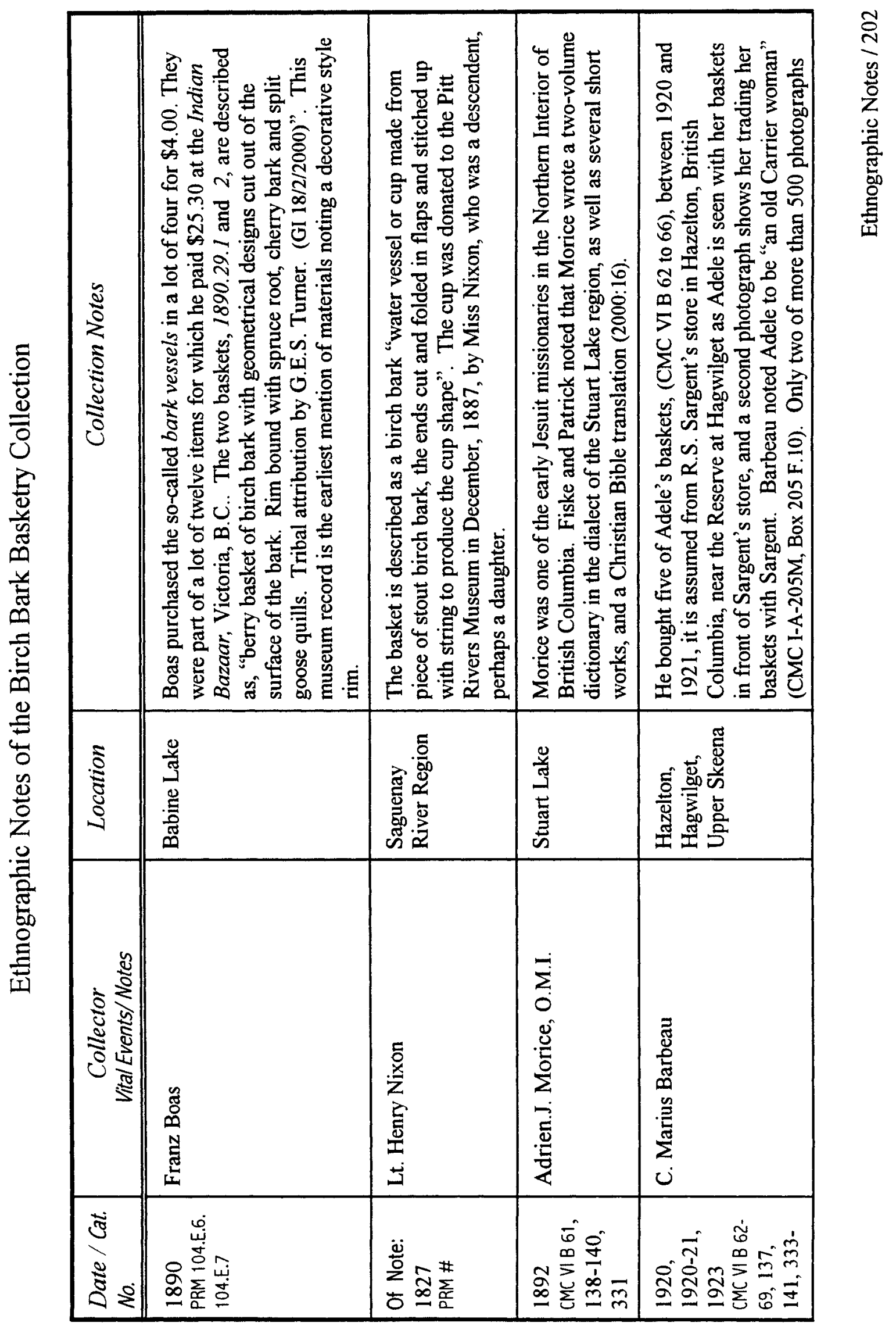




\begin{tabular}{|c|c|c|c|c|c|}
\hline 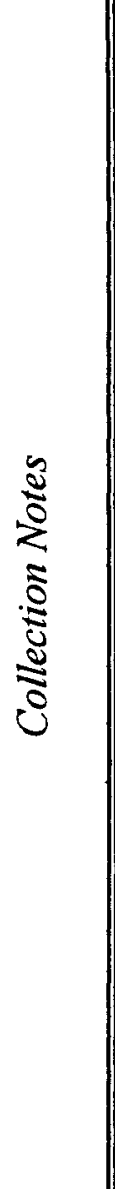 & 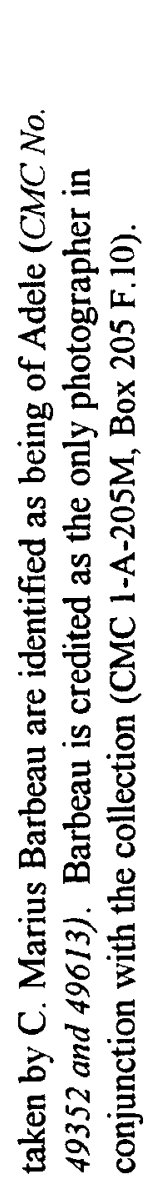 & 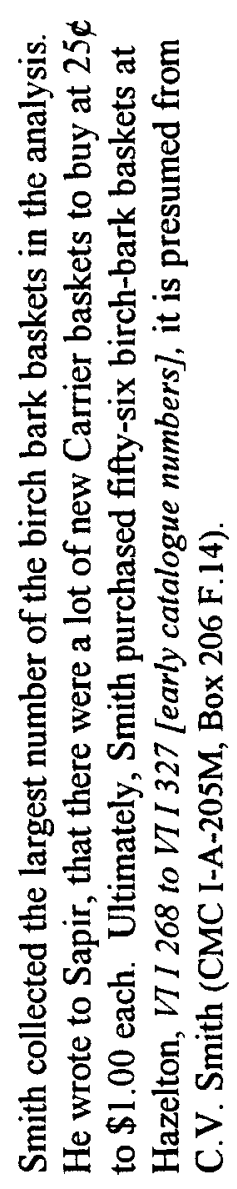 & & 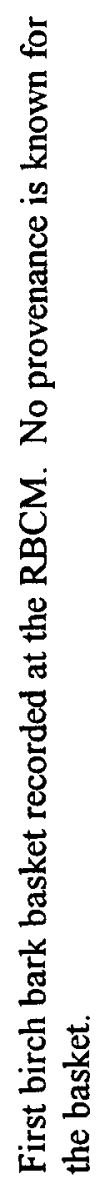 & 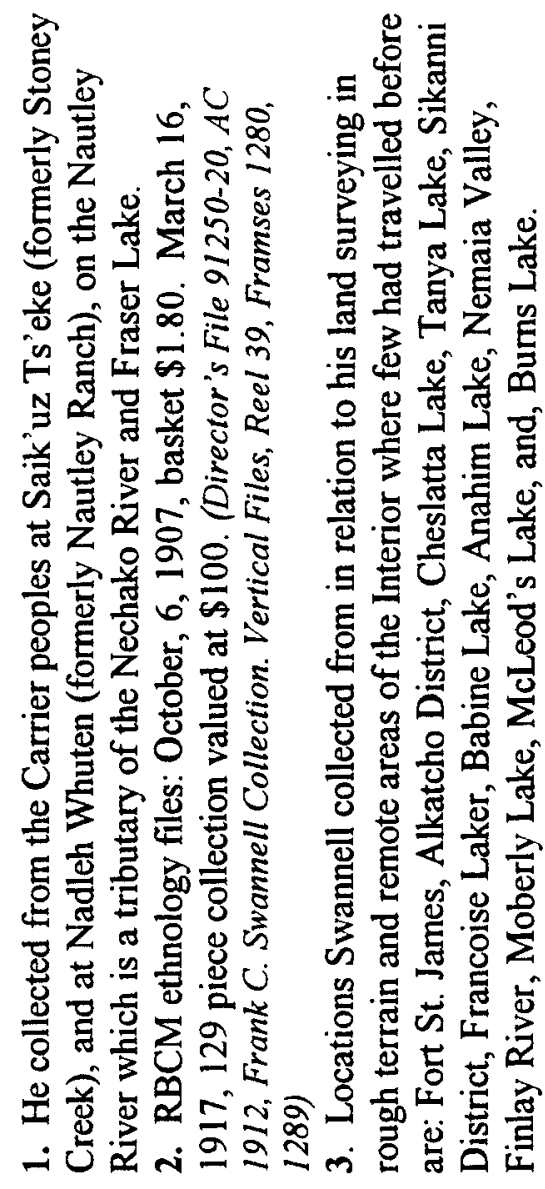 \\
\hline 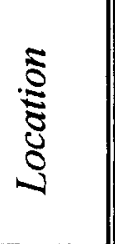 & & 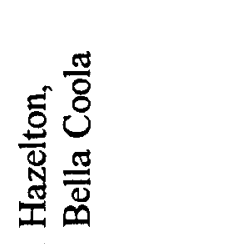 & 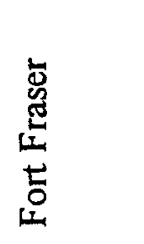 & 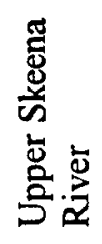 & 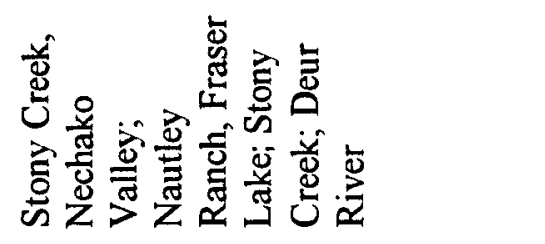 \\
\hline 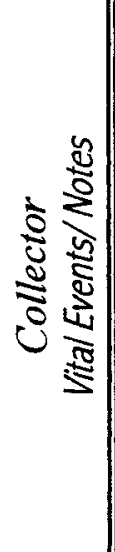 & . & 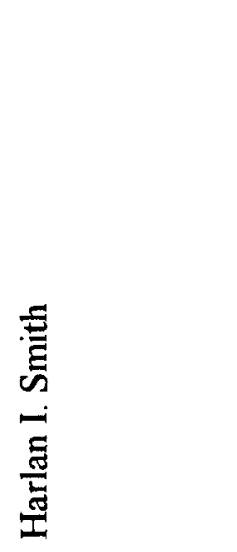 & 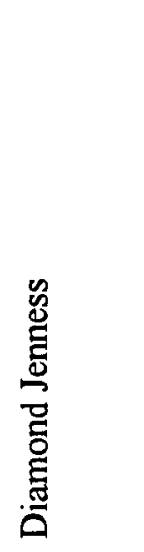 & 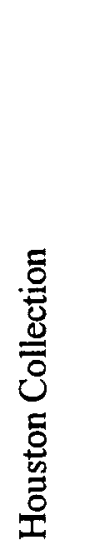 & 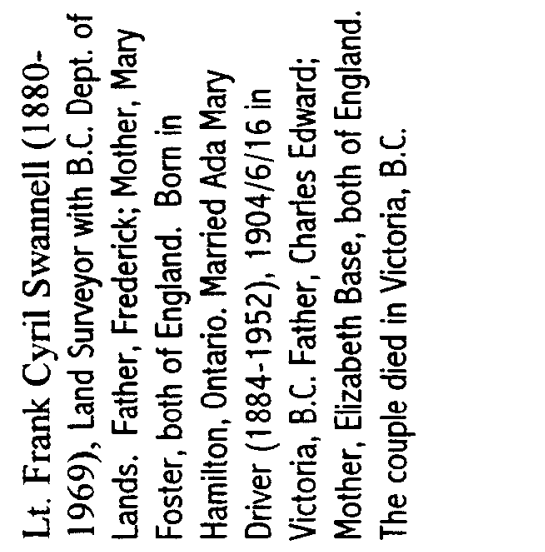 \\
\hline 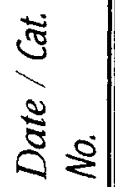 & $m$ & 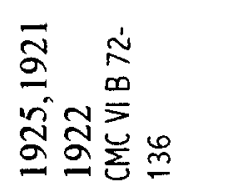 & 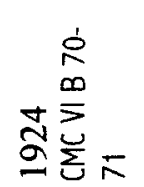 & 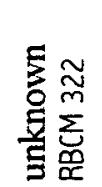 & 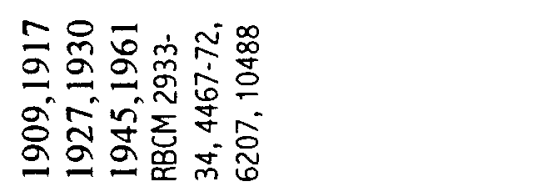 \\
\hline
\end{tabular}




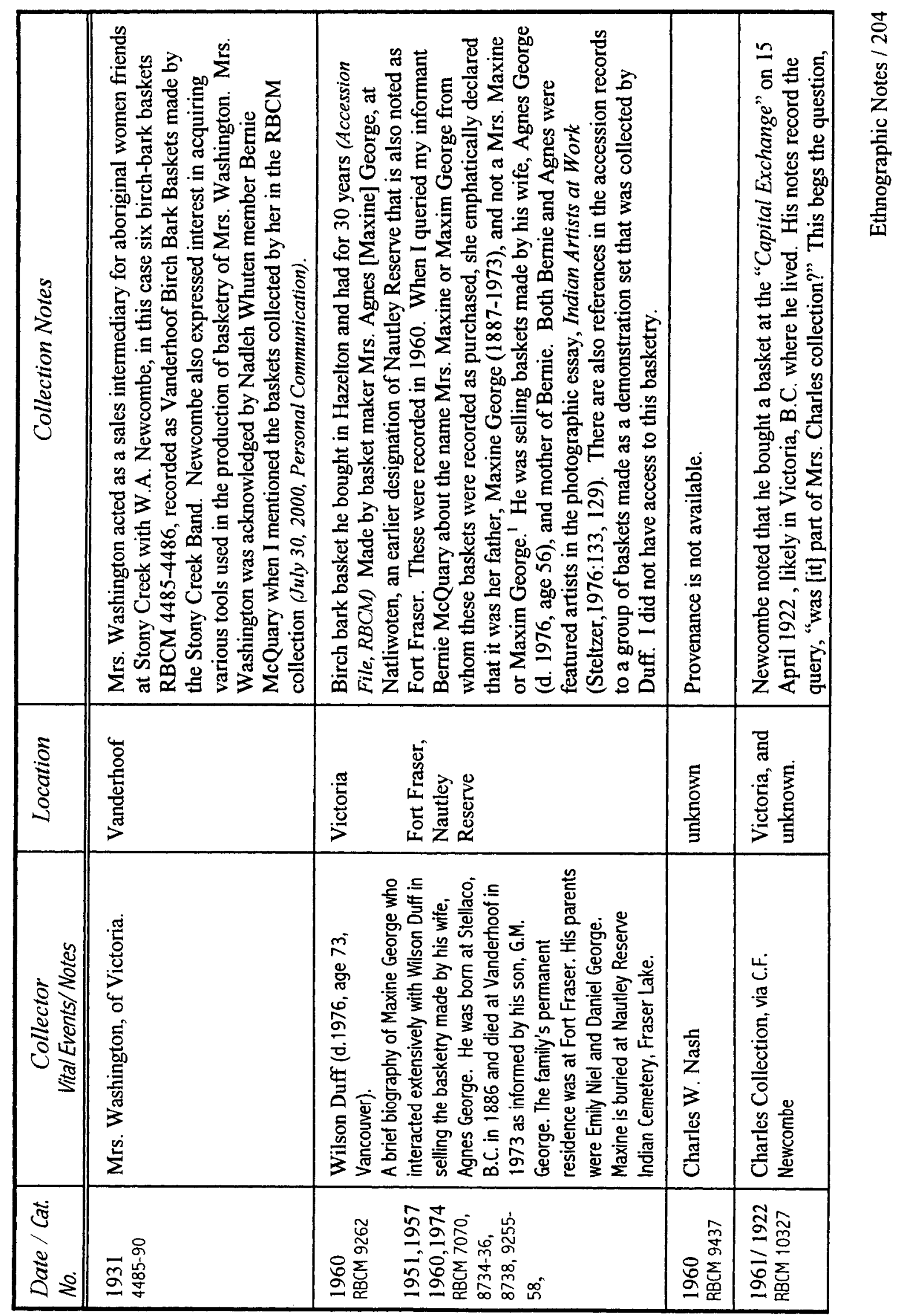




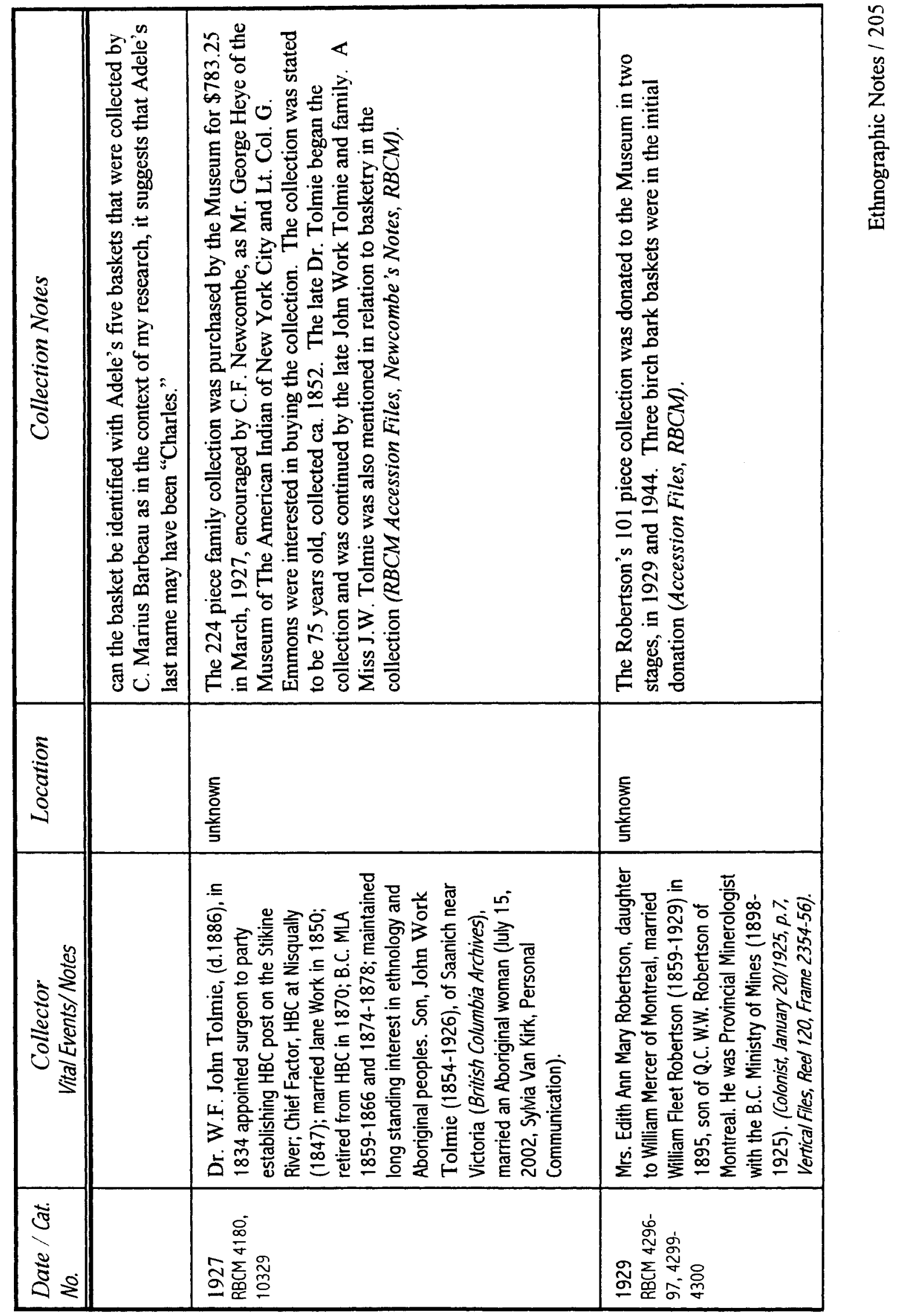




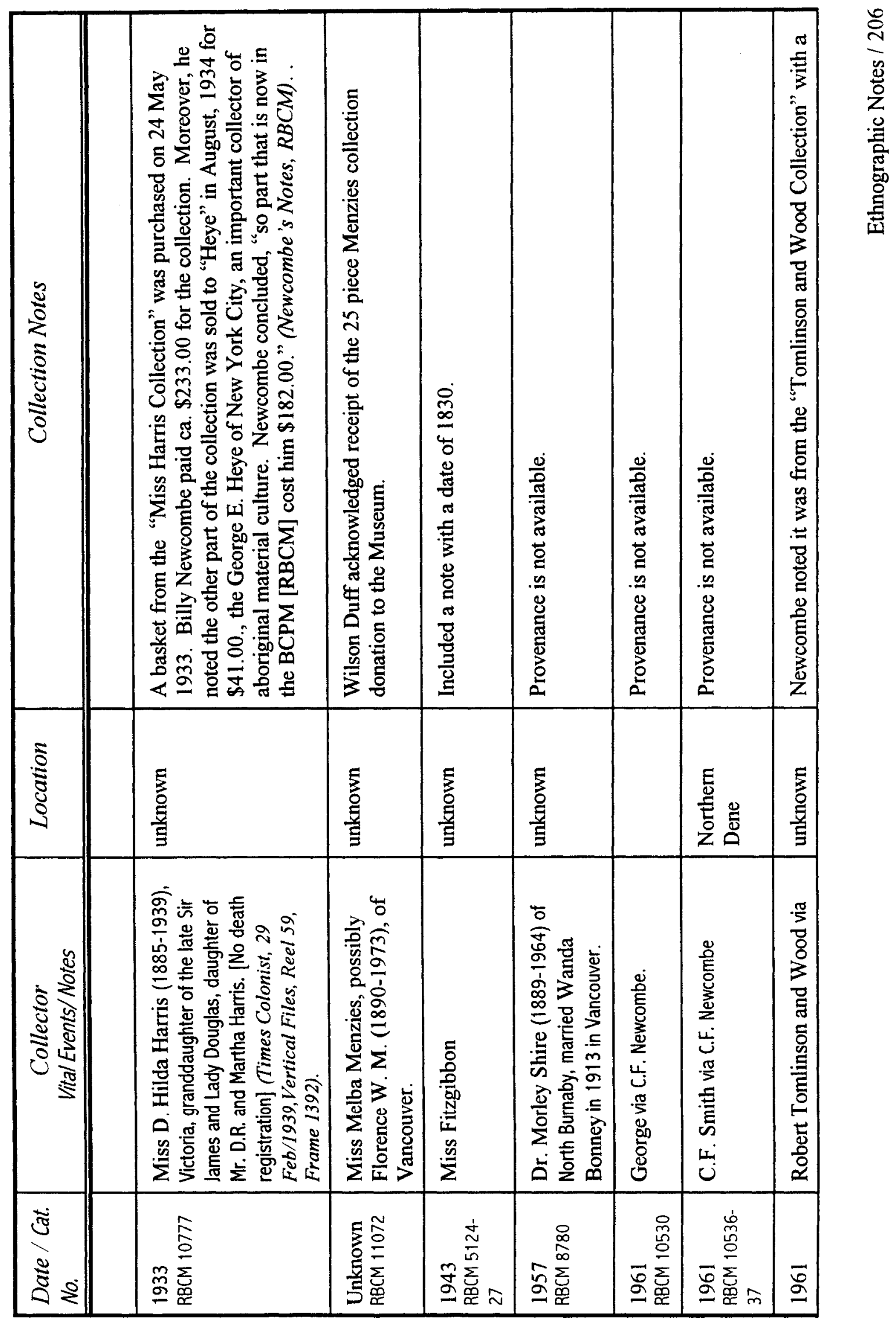




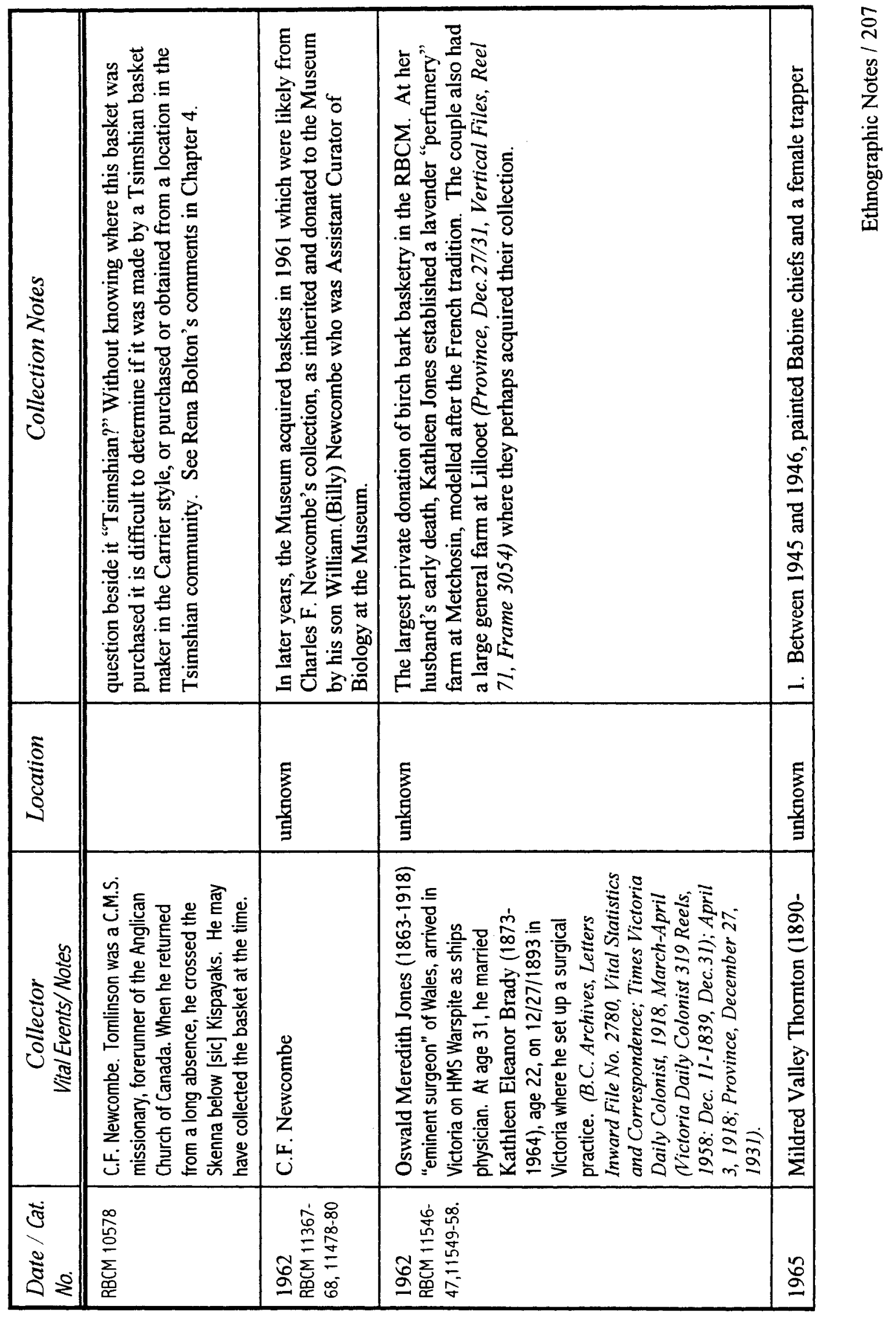




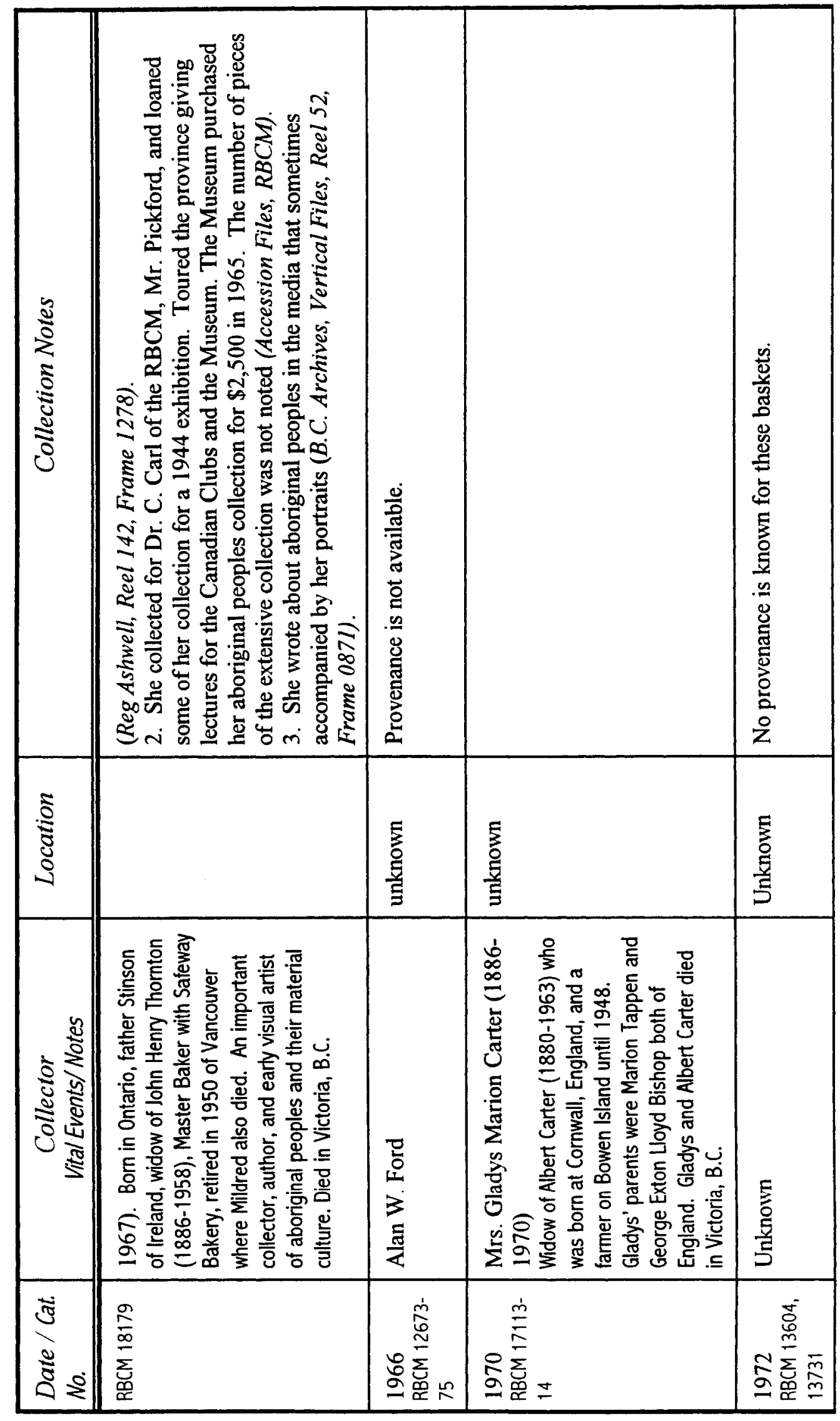

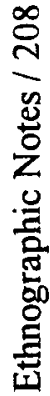




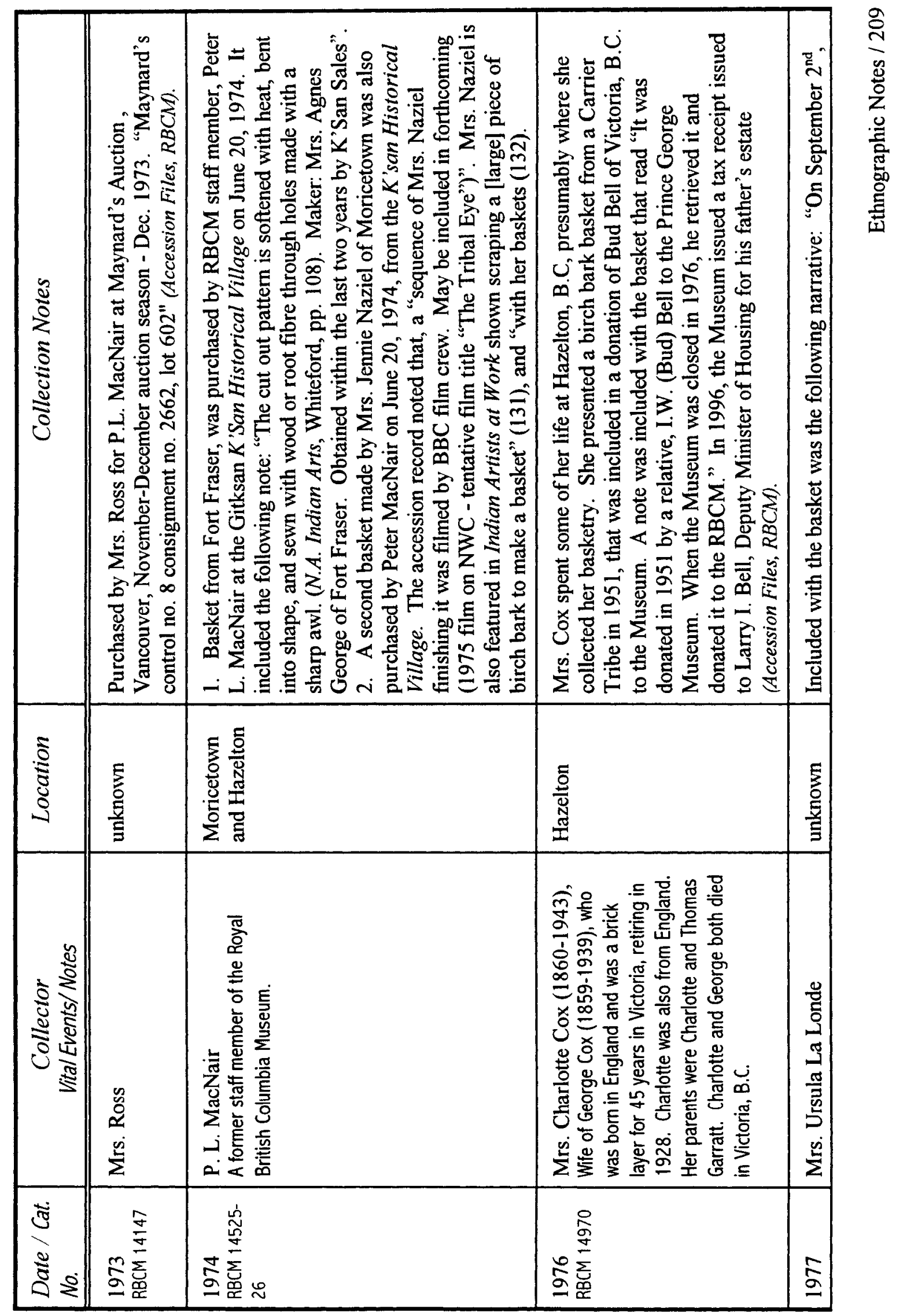




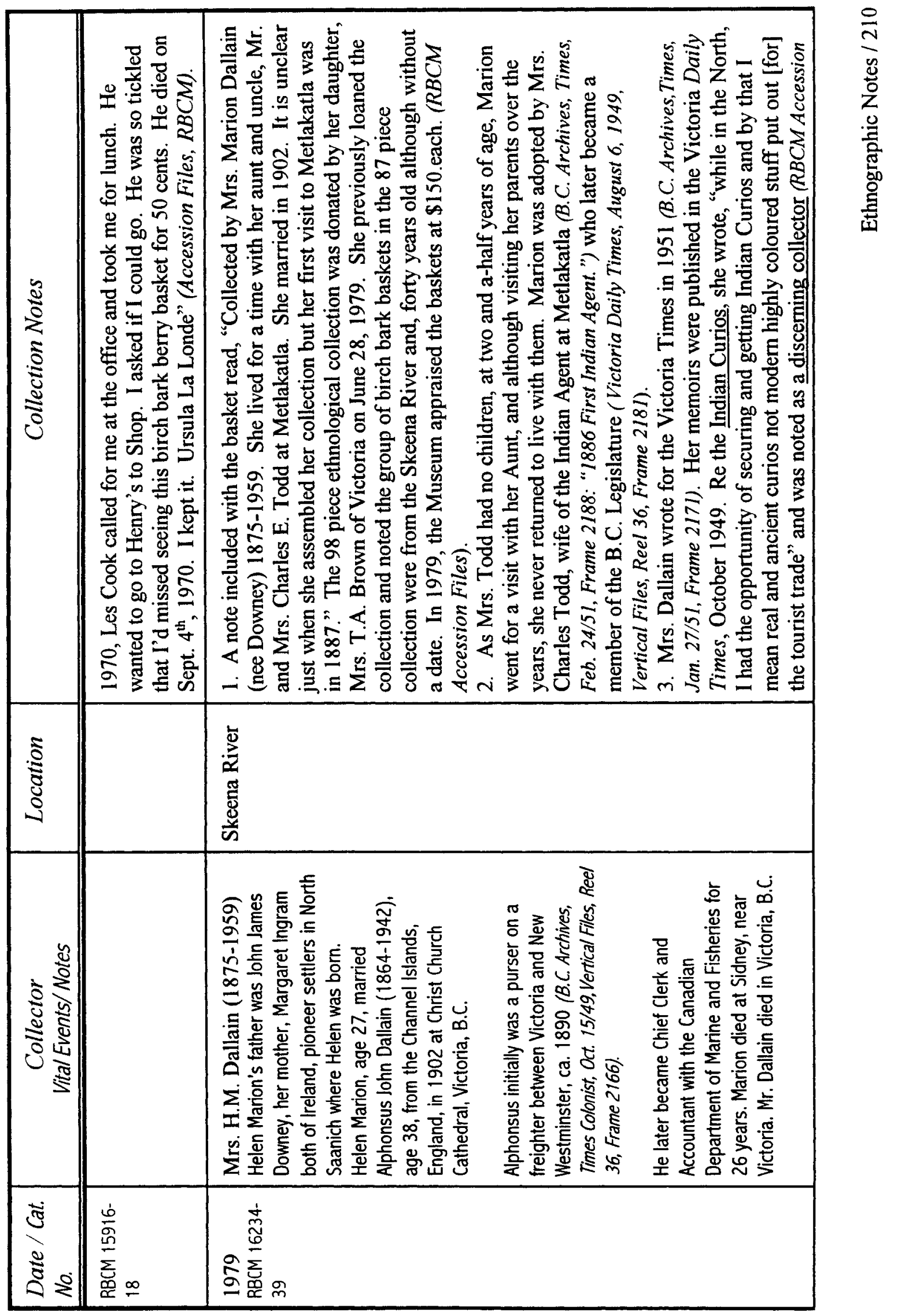




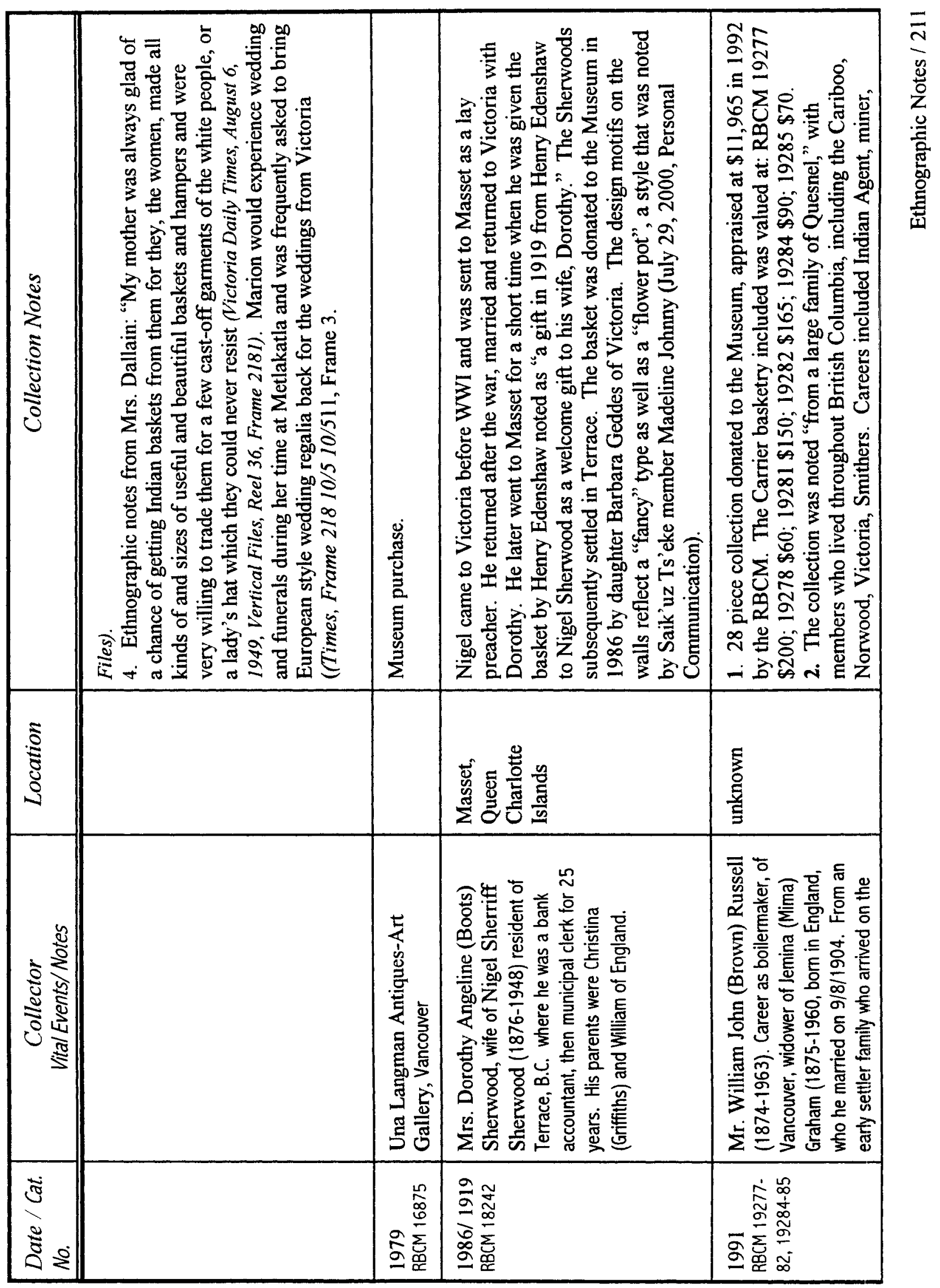




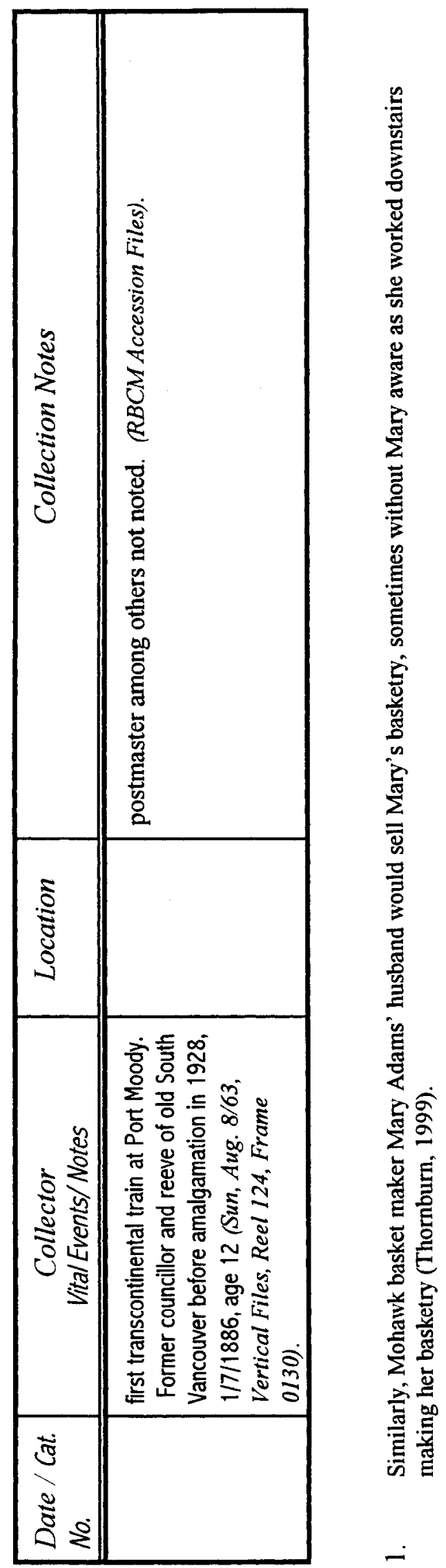

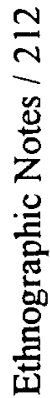




\section{Endnotes}

1. An early Carrier basket (ca.1890), is located in the Pitt Rivers Museum (hereafter PRM) at Oxford, England, its acquisition attributed to Franz Boas. The basket (1890.39.1) is described as a "berry basket of birch bark with geometrical designs cut out of the surface of the bark. Rim bound with spruce root, cherry bark and split goose quills. Tribal attribution by G.E.S. Turner (GI 18/2/2000)."

Boas purchased four baskets in Victoria, British Columbia from the "Indian Bazaar" in March, 1890 . He paid $\$ 4.00$ for a basket photographed in the PRM catalogue (PRM 104.E.6 formerly PRM 1890.39.1). Of the four baskets he collected, at least two are birch bark baskets, recorded to be from the British Columbia Babine Lake (Carrier) region. Boas paid $\$ 25.30$ for the four baskets that were part of a lot of twelve other items. It is noted that the Pitt Rivers Museum record is the earliest mention of materials used in rim decoration.

The basket was formerly recorded at the Pitt Rivers Museum, Oxford, England as 1890.39.1. This was confirmed by e-mail with Museum Collections Assistant Claire Freeman (claire. freemanaprm.ox.ac.uk).

2. At the time, Teit was working in the surrounding area of the Tsilhqot'in people. While Teit's research pertained to the neighbouring Secwepemc people, his well documented descriptions and illustrations provide a contrast to the limited information on the Carrier birch bark basketry which is utilized in the thesis. Teit collected baskets and interviewed weavers, recording names of designs and their meanings. Since 1908, responding to the collector Homer E. Sargent's commission, and guided by Franz Boas' and his theories, Teit set out to discern the attitude of the basket makers toward their work in three ways: technique, form, and the selection of decorative techniques (Jacknis 1992: 144, 149.)

3. Noted by Diana Fane in New Questions for "Old Things": The Brooklyn Museum's Zuni Collection (ca.1992: 63).]

4. A.G. Morice wrote an ethnography of the Carrier people. Morice was working among the central Carrier people when he wrote (1978), The History of the Northern Interior of British Columbia (Formerly New Caledonia) 1660-1880. Wilson Duff referred to the Carrier people (1997) in The Indian History of British Columbia: The Impact of the White Man. Jenness, Diamond wrote (1943) Carrier Indians of the Bulkley River : Their Social and Religious Life / by Diamond Jenness.

Early ethnographies of the Algonquin and Montagnais people and their art were primarily written by Speck. He wrote extensively of their arts in (1937), 
Montagnais Art in Birch-Bark: A Circumpolar Trait. An ethnography by Speck was (1915), Family Hunting Territories and Social Life of Various Algonkian Bands of the Ottawa Valley.

Aspects of the lives of the Algonquin and Montagnais people have been written by several writers. Daniel Clement (1951-) wrote an annotated bibliography in The Algonquins (ca.1996). Meredith Jean Black (1937-) wrote Algonquin Ethnobotany: An Interpretation of Aboriginal Adaptation in Southwestern Quebec (1980) which provided an insight into the terrain the Algonquin people lived in. Eleanor Burke Leacock (1922- ) wrote Relations of Production in Band Society (1982). Leacock also wrote numerous works on the Algonquin people and their traditional organization, including a new theory contrasting with Speck's (1915).

In The Handbook of North American Indians, ethnographic accounts of the Carrier people were in, "Subarctic," by June Helm (vol. ed.) (1981, Volume 6); "Environment and Culture in the Cordillera," by Catherine McClelland and Glenda Denniston, (372-386); "Intercultural Relations and Cultural Change in the Cordillera," by Catherine McClellan (387-401); and, "Carrier," by Margaret L. Tobey (413-432). In other volumes of this extensive work, articles on ethnographical research of the Algonquin and Montagnais people include "Northeast," Bruce E. Trigger (vol. ed.) (1978a, Volume 15), "Algonquin," by Gordon M. Day and Bruce G. Trigger (792-797); and, "Cultural Unity and Diversity," by Bruce G. Trigger (798-804) completing the ethnographic survey

Tsimshian Ethnographies: An ethnography written by Franz Boas was published in the Thirty-first Annual Report of the American Bureau of Ethnology (1909-10) (see Map 5-6). Referring to the traditional Tsimshian domestic economy in "Tsimshian Mythology," Boas described the life, social organization, religious ideas and practices of Tsimshian mythology.

Viola E. Garfield (1899-1983) wrote "Tsimshian Clan and Society" (1939: 167340). The study was based on her field work in the summer of 1932,1935 , formal structure of the Tsimshian people's social organization by Boas.

Anthropologist Ruth Benedict (170-171) assisted in the completion of the study. Barbeau (1953) wrote "Totem Poles" in Totem Poles According to Location. He also considered the Tsimshian domestic economy. Barbeau gathered his information during field work among the Tsimshian from 1915 to 1947 for the [Canadian] National Museum of Man. Anthropologists John Cove and George F. MacDonald (1987) edited Barbeau and Benyon's work in Trade and Warfare: Tsimshian Narratives 2 and included was a two page essay on the early historical contact by European people (xviii-ix); another on warfare ( $x x-x x v)$.

5. Canadian Museum of Civilization, Harlan I. Smith Collection (VI-B-32M), The Material Culture of the Carrier Indians of British Columbia (pt. 5 (184 to end), 
Box 88 f.5:103 (2).

6. Paper titled "Materia Medica of the Bella Coola and Neighbouring Tribes of British Columbia" by Harlan I. Smith. Department of Mines, National Museum of Canada, Bulletin No. 56, Annual Report for 1927.

7. Canadian Museum of Civilization, Archives Division, Harlan I. Smith Collection (VI-B-32M), The Material Culture of the Carrier Indians of British Columbia (pt. 5 (184 to end), Box 88 f.5:103 (2).

8. See Swannell's Subject Files for extensive details of the Trade Routes and Grease Trails by Sir Alexander MacKenzie in 1793 who traveled the routes on his way to the Pacific. His Subject Files also include his extensive observations and information gleaned of the Grease Trails during his survey work in the area ca.1913, and "New Trail" a Report he wrote in 1952 a new Trail was added in 1930. MS-0392. Swannell, Frank Cyril (1880-1969) Vol. 76, Box 12. "Subject Files containing notes and Correspondence." British Columbia Archives.

9. It was interesting to find a Carrier birch bark basket donated to the RBCM by Miss Hilda D. Harris. Miss Harris is a great-grand daughter of Sir James Douglas. September 24, 2002, The British Columbia History Internet/Web Site, New Caledonia Metis Association, Hudson's Bay Co. Employees in New Caledonia http://www.Victoria.tc.ca/resources/bchistory.orgs.html.

10. Was their economy based on a traditional system of trapping territories belonging to families, or, was it a system altered and thus dependent on their commitment to the European fur trade through the trading company? Interpretations of this question are discussed by the following contemporary ethnographers (see Bibliography for the complete reference). June Helm (1961); June Helm and Eleanor B. Leacock (1971); Eleanor B. Leacock (1982); Frank G. Speck (1926), (1935), (1915); Edward S. Rogers (1972); Siomonn Pulla (2000); Diamond Jenness (1997); Julian Steward (1977), (1955), (1960), and Brian J. Given (1994)

11. The Fort is now a Canadian historical site with exhibits providing information on the fur trade at that location through re-enacted activities presented by staff in period costumes. In several rooms were exhibits that included Carrier birch bark baskets. Some basketry similar to those considered here, were stocked in the store for trade.

12. National Archives of Canada, RG 10 Files, Agency Records 1812-1927, Volume 1585, Letterbook, 1889-1898.

13. The Northwest Coast Agency was established in 1883 but was not active until 1887 to 1910 . The Lillooet agency and the Williams Lake agencies were also created at this time. In 1884, the Kamloops and Okanagan agencies amalgamated 
and in 1886, the Kootenay Agency was created.

14. Developed by OMI Pierre P. Durieu (1830-1899), in 1860, among the Sechelt people of British Columbia. It was intended to enforce Christian teachings, beliefs and values on the Sechelt people because, as Durieu stated,

"The Indian is weak in heart and mind ... and must be ruled by religious motives .... He must be protected against himself and against evil-doers .... He must be paternally guided (for) ... Indians are only big children ... and hence [have] need for other than regular white law and control .... (Bunoz 1942: 193209)."

The System was applied in some areas of British Columbia, including at the Fort Fraser Mission at Stuart Lake, by A.G. Morice O.M.I.. Discussion of the system and it's repercussions can be found in (full references in the Bibliography): Gaston Carriere, O.M.I. (1978); Wilson Duff (1964 [1977]); June Helm and Eleanor Leacock (1971); Edwin M. Lemert (1954); Adrien G. Morice (1978); David Mulhall (1986); Derek G. Smith (2001); Margaret L. Tobey (1981); and, Margaret Whitehead (1988).

15. Indian Residential School Study: 1992-1994." Indian Residential Schools: The Nuu-chah-nulth Experience. Report of the Nuu-chah-nulth Tribal Council. 1996.

16. MS-0392. Swannell, Frank Cyril (1880-1969) Vol. 51, Box 12. "Subject Files containing notes and Correspondence." British Columbia Archives.

17. www.geonames2.nrc.gc.ca.

18. The Ursuline Order was founded in France on November 25, 1535 by St. Angela Merici. The fourth vow for the instruction of girls was added to the existing Augustinian vows. By late sixteenth-century, the Ursuline Order was extended to Germany. In 1639, the first convent was established in North America at Quebec City by Patron Madame de la Peltrie (Volume 1, The Jesuit Relations, 1927: 483, n1).

19. During my visit of 1999 to the Ursuline Museum in Quebec City, Quebec, exhibit cases portrayed past works of the Sisters. Included were examples of teaching handwork to aboriginal women, accompanied by birch bark baskets. Along with the tapestries hung around the room, a second display case contained paper cutouts of floral designs. They suggested patterns used in creating the tapestry and other church liturgical fabrics. 
20. The remarkable earliest history of aboriginal people in Canada ca. 1611-1764, from the records of over three hundred Jesuit missionaries of the Society of Jesus.

21. Was their economy based on a traditional system of trapping territories belonging to families, or, was it a system altered and thus dependent on their commitment to the European fur trade through the trading company? Interpretations of this question are discussed by the following contemporary ethnographers (see Bibliography for the complete reference). June Helm (1961); June Helm and Eleanor B. Leacock (1971); Eleanor B. Leacock (1982); Frank G. Speck (1926), (1935), (1915); Edward S. Rogers (1972); Siomonn Pulla (2000); Diamond Jenness (1997); Julian Steward (1977), (1955), (1960), and Brian J. Given (1994).

22. Personal Communication, Siomonn. Pulla, January 23, 2003.

23. Bill No 66: the Historic Objects Preservation Act, was tabled by the provincial government of British Columbia. On October 5, 1926, the Royal Society of Canada followed suit by unanimously adopting a resolution concerning the trafficking of Canadian native cultural material. This all came to a head in 1927 when The [Ottowa] Citizen ran an article concerning the purchase, and removal to the United States, of a collection of very old Carrier Indian birch-bark trays and baskets from Hazleton, British Columbia by Frank G. Speck, chair of the anthropological department of the University of Pennsylvania. The Winnipeg Evening Tribute ran an article in 1928 on the same theme lamenting the export of "historical antiquities" from Canada (NAC RG45 Vol. 43 File 1759B) [Courtesy of Siomonn Pulla, 2000].

24. Canadian Museum of Civilization, Archives Division, Edward Sapir's Correspondence (I-A-236M), Folder Smith H.I. (1911-1920), Box 633 f.40.

25. April 25, 2001, at the home of Mary Thomas, Personal Communication.

26. July 29, 2000, at the home of Madeline Johnny, Personal Communication.

27. April 25, 2001, at the home of Mary Thomas, Personal Communication.

28. This example was provided by Dr. Andrea Laforet from the unpublished manuscript, Basketry in British Columbia: 1778-1930.

29. Canadian Museum of Civilization, Archives Division, Harlan I. Smith Collection (VI-B-32M), The Material Culture of the Carrier Indians of British Columbia (pt. 3 (59-87), Box 88 f.3: 170. 
30. Canadian Museum of Civilization, Archives Division, Harlan I. Smith Collection (VI-B-32M), The Material Culture of the Carrier Indians of British Columbia (pt. 3 (59-87), Box 88 f.3:170.

31. July 29, 2000, at the home of Madeline Johnny, Personal Communication.

32. June $21^{\text {st }}, 2000$, Louise Joseph, Personal Communication. Hagwilget, British Columbia.

33. July 29 and 30, 2000 respectively in the homes of Madeline Johnny, and Bernie McQuary, Personal Communication.

34. September 1, 2001, Mary Aski-Piyesiwiskwew Longman, Personal Communication, Victoria, British Columbia and, The Ring, University of Victoria Community Newspaper. Vol. 27, No. 9.

35. April 25, 2001 at the home of Mary Thomas, Personal Communication.

36. August 4, 2001, at the home of Rena Bolton, and in a subsequent telephone conversation.

37. “An Ethnographic Enterprise: A Cultural Exploration of Ojibway Traditional Crafts and Contemporary Non-Figurative Art." Undergraduate course 54.410, Department of Sociology and Anthropology, Carleton University, Ottawa, Ontario. 1996-7.

38. November 23, 2001, Stella Johnny, Personal Communication

39. April 25, 2001, Mary Thomas, Personal Communication.

40. Canadian Museum of Civilization, Archives Division, Collector's Files, Coll: (I-A205M), Folder Barbeau, C. Marius (1915-1921), Box 205 f. 10.

41. Canadian Museum of Civilization, Archives Division, Collector's Files, Coll: (I-A205M), Folder Barbeau, C. Marius (1915-1921), Box 205 f.10.

42. I found the history to be similar to that of Mohawk basket maker Mary Adams. In the early years, ca. 1930s, Mary sold her basketry by the dozen to a local merchant named Archie (Archibald) McKinnon. In later years she sold them directly from her home (Thornburn, 2001, 1999). Independent researcher of Mohawk basketry, Frank Bergevin with whom I have been in communication during the past two years, and who lives close to the former McKinnon U.S. store explained, the McKinnon store was a family operated business located at Hogansburg on what was then called the St. Regis Reservation (now Akwesasne). Bergevin has 
reproduced McKinnon's wholesale Mohawk basketry catalogue (sold by the dozen), ca.1915. He explained that the McKinnon Store operated like the traditional trading post, trading provisions (never paying money) for baskets. McKinnon would also select "standards" or types which he would have the Natives produce; mostly in the fancy basket categories, since traditionally most of the baskets were utilitarian. I believe this interplay may have resulted in some hybrid creations that are now respected forms. He explained to me that he has been putting together a collection of objects from the catalogue, all with the tags and one in the original box (September 18, 2002, Frank Bergevin, Personal Communication).

43. Canadian Museum of Civilization, Archives Division, Collector's Files, Coll: (I-A205M), Folder Barbeau, C. Marius (1915-1921), Box 205 f. 10.

44. Sapir had asked Barbeau to gather aboriginal material culture among other tasks while Barbeau was engaged in ethnological work with the Tsimshian people. March 23, 2002, Dr. Andrea Laforet, Personal Communication.

45. Canadian Museum of Civilization, Archives Division, Collector's Files, Coll: (I-A205M), Folder Barbeau. C. Marius (1915-1921), Box 205 f 10.

46. August 1, 2000, at the home of Ward McKenzie, Hazelton, B.C. Personal Communication.

47. August 1, 2000, Hazelton Pioneer Museum Archives, Hazelton, B.C..

48. Reel T6554, British Columbia 1901 Census: 1901 - Indian Reserves - British Columbia, Book 2, Babine Indian Agency. National Archives of Canada, Ottawa, Ontario: 38 pps.

49. Reel T6554, British Columbia 1901 Census: Indian Reserves - British Columbia, Book 2, Babine Indian Agency. National Archives of Canada, Ottawa, Ontario: 38 pps.

50. National Archives of Canada, RGI0 Files, Agency Records 1812-1927, Vol.1589.

51. National Archives of Canada, RG 10 Files, Agency Records 1812-1927, Vol. 1022.

52. National Archives of Canada, RG 10 Files, Agency Records 1812-1927, Vol.1583.

53. National Archives of Canada, RG10 Files, Agency Records 1812-1927, Vol.1022.

54. Canadian Museum of Civilization, Archives Division, Collector's Files, Coll: (I-A205M), Folder Barbeau, C. Marius (1915-1921), Box 205 f. 10. 
55. Canadian Museum of Civilization, Archives Division, Collector's Files, Coll: (I-A205M), Folder Barbeau, C. Marius (1915-1921), Box 205 f. 11

56. The Royal British Columbia Museum anthropologist Wilson Duff (1951-1974) collected three Carrier baskets from his contacts in the Carrier community at Fort Fraser (Nautley Reserve). Duff developed a relationship with Maxine George, who was Bernie McQuary's father and became Duff's informant. There was confusion with reference to Chief George's given name. His first name has been spelled either Maxine, or, Maxime. It is further confusing as Bernie McQuary stated her father's name was Maximillian. He may have been addressed with all three names. Said in different dialects, it may explain the inconsistent spelling of his given name as well.

At the start of a visit in 1957, Duff noted he "made a note to himself, get copy of new Indian Act and send to Chief Maxime George, Fort Fraser, B.C." On October $21^{\text {st }}$, Duff stated he "stopped for a couple of hours at Fort Fraser and saw Maxine George and his family. He ordered 1 lge birch bark basket, 3-stages in making a small basket and 3-stages in making a moccasin, to be picked up on the way."

On October $31^{\text {st }}$, returning from Hazelton to Victoria, he stopped at Fort Fraser and "picked up birch bark and moccasins he had ordered. $\$ 20.00$ for the baskets and $\$ 10.00$ for the moccasins, [noting] Mrs. [Agnes] George can make several things." (Reel B6045. W. Duff Field Notes. Notebook 16. CAR-W-002 or TSI-W003. British Columbia Archives.)

57. August 1, 2000, Laurel Mould, Executive Director, K'san Historical Village, Personal Communication, Hazelton, British Columbia.

58. April 25, 2001, Mary Thomas, Personal Communication.

59. August 3, 2000, Rena Bolton, Personal Communication. Terrace, British Columbia.

60. October 20, 2001, Pauline Joe, Personal Communication. B.C. Women's History Conference. Duncan, British Columbia.

61. November 23, 2001, Kathy Edgar, Duncan, British Columbia, Personal Communication.

62. With vendor Delores Montour, a local Mohawk basket maker/teacher that I had taken lessons in Mohawk basketry from. 
63. October 20, 2001, Pauline Joe, Personal Communication. B.C. Women's History Conference. Duncan, British Columbia. November 23, 2001, Kathy Edgar, Personal Communication, Duncan, British Columbia. 


\section{Bibliography}

\section{ARCHIVAL SOURCES}

British Columbia Archives

W. Duff's Field Notes, Reel B6403 Carrier File 1. CAR-W-001. Notebook Number 15; Reel B6045 CAR-W-002 or TSI-W-003, Notebook Number 16. British Columbia Archives.

Lieutenant Frank Cyril Swannell (1880-1969) MS-0392. Vol. 51, Box 12; Vol. 52. Box 8, Vol. 76, Box 12. "Subject. "Subject Files containing notes and Correspondence;" Vol. 2, Diaries 1908; Box 12. File 76/2. "Notes re Finlay River and Finlay Family. British Columbia Archives.

Smithers Interior News. November 14, 1970: 3. Reel 55. Frame 2708. Vertical Files. British Columbia Archives.

Canadian Museum of Civilization, Archives Division, Ethnological Records, Hull, Quebec Barbeau, C. Marius (1915-1921), Collector's Files, Coll: (I-A-205M), Folder, Box 205 f. 10; Box 205 f.11; Box 206 f14;

Barbeau, C. Marius (1920), Edward Sapir's Correspondence, (I-A-236M), Box 633 f.41; Box 620 f.23.

Sapir, Edward (1911), Harlan I. Smith Correspondence, (I-A-242M), Box 217 f.22.

Sapir, Edward (1921-1925), Marius Barbeau's Correspondence, Box B237 f.7.

Smith, Harlan I. (1911-1920), Edward Sapir's Correspondence (I-A236M), Box 633 f.40.

Smith, Harlan I. "The Material Culture of the Carrier Indians of British Columbia," (pt. 3 (59-87), Box 88 f.3: 170 ; Part V, 184 Art to End. (VIB-32M), Box 88 f.5:103 (2).

Government of Canada

19831881 Census of Canada. Vol. 1, 2. Ottawa, Ontario: Queen's Printer.

1911 Annual Report of the Department of Indian Affairs, for the Year Ended March 31 1911. Hull, Quebec. 
Hazelton Pioneer Municipal Archives

2000

P.O. Box 323, 4255 Government Street, Hazelton, British Columbia, V0J $1 Y 0$.

National Archives of Canada

1901

Census of Canada, British Columbia: Indian Reserves - British Columbia; Book 2, Babine Indian Agency. Reel T-6554, 38 pps. RG 10 Files.

1812-1927 Babine Agency Records, 1888-1920, Reels C-14855 to C-14857, Volume 1022; Volume 1583; Volume 1585, Letterbook, 1889-1898; Volume 1589; RG 10 Files.

\section{MONOGRAPHS AND JOURNALS}

Anonymous

1869 Catalogue of Antiquities and Curiosities Collected in the Territory of Alaska by Edward G. Fast. Boston: Leavitt, Strebeigh \& Co.

An Ursuline of Quebec, 1639

1939 Mary of the Incarnation: Founder of the Ursuline Monastery. Quebec City, Quebec: The Ursuline Monastery, Parlor Street.

Adovasio, J.M.

Basketry Technology: a Guide to Identification and Analysis. Chicago: Aldine Publishing Company.

Arnold, Grant

1996

Topographies: Recent Aspects of B.C. Art, Doreen Jensen, Monika Ken Gagnon and Grant Arnold. Vancouver: Vancouver Art Gallery.

Barman, Jean

1996

The West Beyond the West: A History of British Columbia. Toronto: University of Toronto Press Incorporated.

Barrett, Samuel A.

$1908 \quad$ "Pomo Indian Basketry." American Archaeology and Ethnology 7.

California: University of California Publications: 133-276.

Berlo, Janet. C. ed.

1992 "Introduction: The Formative Years of Native American Art History." The 
Early Years of Native American Art History. Seattle: University of Washington Press: 1-21.

Berlo, Janet C. and Ruth B. Phillips

1998 Native North American Art. New York: Oxford University Press.

Bernstein, Bruce

1998 Native Paths: American Indian Art from the Collection of Charles and Valerie Diker. New York: The Metropolitan Museum of Art.

Black, Meredith Jean 1980 Algonquin Ethnobotany: An Interpretation of Aboriginal Adaptation in Southwestern Quebec. Mercury Series. Ottawa: National Museums of Canada.

Boas, Franz 1955

Primitive Art. New York: Dover Publications, Inc.

$1928 \quad$ Coiled Basketry in British Columbia and Surrounding Region, by H.K Haeberlin, James A. Teit, and Helen H. Roberts under the direction of Franz Boas. Washington : Govt. Printing Office.

1892

"Notes on the Chemakum Language." American Anthropologist, January, Vol. 5: 37-44.

Bunzel, Ruth 1929

The Pueblo Potter: A Study in Creative Imagination in Primitive Art. New York: Columbia University Press.

Carriere, Gaston

1978 in Morice, A.G., OMI, The History of the Northern Interior of British Columbia (Formerly New Caledonia) 1660-1880. Frontispiece (1). Toronto: William Briggs.

Cassidy, Maureen

1987 The Gathering Place: A History of the Wet 'suwet'en Village of Tse-kya. Hagwilget, B.C.: Hagwilget Band Council.

Cassidy, Maureen and Frank Cassidy 1980

Proud Past: A History of the Wet 'suwet'en of Moricetown, B.C. Moricetown, B.C.: Moricetown Band. 
Clément, Daniel

1996

The Algonquins. Hull, Quebec: Canadian Museum of Civilization.

Colonial and Indian Exhibition

1886

Official Catalogue of the Canadian Section, The Colonial and Indian

Exhibition, England. Published under the authority of the Executive

Commissioner, The Honorable Sir Charles Tupper. England.

Coull, Cheryl

1996

A Traveller's Guide of Aboriginal B.C. Vancouver: British Columbia:

Whitecap Books.

Dickason, Olive Patricia

2002 Canada's First Nations: A History of Founding Peoples from Earliest

Times. $3^{\text {rd }}$ Edition. Don Mills, Ontario: Oxford University Press.

1992 Canada's First Nations : A History of Founding Peoples from Earliest

Times. Toronto : McClelland \& Stewart.

Day, Gordon M., and Bruce G. Trigger

1978 "Algonquin: Great Lakes - Riverine Region." Northeast. Vol. 15. Bruce

G. Trigger, Vol. Ed. Handbook of North American Indians. Washington,

D.C.: Smithsonian Institution: 792-97.

Devine, Sue

1982

"Spruce Root Hats of the Tlingit, Haida and Tsimshian." American Indian Basketry. No. 1, Vol. 4: 20-5.

1981 "Kwakiutl Spruce Root Hats." American Indian Basketry. No. 1, Vol. 4: 24-7.

Duff, Wilson 1997

The Indian History of British Columbia: The Impact of the White Man. Previously published under title: The Indian History of British Columbia, Vol. 1, The Impact of the White Man, 1992. Victoria, B.C.: The Royal British Columbia Museum.

1951 "Notes on Carrier Social Organization." Anthropology in British Columbia. Vol. 2: 28-34. Victoria. 
Elsey, $\mathrm{Al}$

1964

Grease: Oolican Oil Production on the Bella Coola River. A Story of the

Nuxalk Nation, starring Dr. Margaret Siwallace. Videocassette (27 min.) : sd., col. ; 1/2 in. Producer: Al Elsey.

Fane, Diana 1992

"New Questions for “Old Things": The Brooklyn Museum's Zuni Collection" in The Early Years of Native American Art History. Seattle: University of Washington Press: 62-87.

Fiske, Joanne 1996 "Gender and the Paradox of Residential Education in Carrier Society" in Women of the First Nations: Power, Wisdom and Strength. Christine Miller and Patricia Chuchryk, eds., with Marie Smallface Marule, Brenda Manyfingers, and Cheryl Deering. Winnipeg: University of Manitoba Press: $167-182$.

Fiske, Jo-Anne and Betty Patrick

2000 Cis dideen kat $=$ When the Plumes Rise: The Way of the Lake Babine Nation. Vancouver: University of British Columbia.

Francis, Daniel and Toby Morantz 1982 Partners in Furs: A History of the Fur Trade in Eastern James Bay, 16001870. Kingston, Ontario: McGill-Queen's University Press, 1982.

Furniss, Elizabeth Mary

1993 Dakelh Keyoh: The Southern Carrier in Earlier Times. Quesnel, B.C.: Kluskus, Nazko, Red Bluff, and, Ulkatcho Bands.

Gagnon, Monika Ken

1996 Topographies: Recent Aspects of B.C. Art, Doreen Jensen, Monika Ken Gagnon and Grant Arnold. Vancouver: Vancouver Art Gallery.

Garfield, Viola E.

n.d. The Tsimshian Indians and Their Arts: The Tsimshian and Their Neighbours. Originally "The Tsimshian: Their Arts and Music, publication XVIII of the American Ethnological Society, Marion W. Smith ed. Seattle, Washington:University of Washington Press.

Gibson, James R.

$1991 \quad$ Otter, Skins, Boston Ships, and China Goods: The Maritime Fur Trade of the Northwest Coast, 1785-1841. Montréal: McGill-Queen's University Press. 
Gillespie, Beryl C.

1981 "Major Fauna in the Traditional Economy." Subarctic. Vol. 6. June Helm, Vol. Ed. Handbook of North American Indians. Washington, D.C.: Smithsonian Institution: 15-8.

Golden Gate International Exposition 1939

Pacific cultures, Department of Fine Arts, Division of Pacific Cultures.

California: San Francisco

Haeberlin, H.K., James A. Teit, Helen H. Roberts, Franz Boas (ed.)

1928 "Coiled Basketry in British Columbia and Surrounding Region, Forty-First Annual Report of the Bureau of American Ethnology to the Secretary of the Smithsonian Institution, 1919-1924. Washington: United States Government Printing Office.

Harris, Cole 1997

"Strategies of Power in the Cordilleran Fur Trade" in, The Resettlement of British Columbia: Essays on Colonialism and Geographical Change. Vancouver: UBC Press: 31-67.

Harris, Cole and Robert Galois

1997 "A Population Geography of British Columbia in 1881" in The Resettlement of British Columbia: Essays on Colonialism and Geographical Change. Vancouver: UBC Press: 137-160.

Helm, June 1961

The Lynx Point People: The Dynamics of a Northern Athapaskan Band. Bulletin 176. Ottawa: National Museum of Canada.

Helm, June, Edward S. Rogers, and, James G.E. Smith 1981 "Intercultural Relations and Cultural Change in the Shield and Mackenzie Borderlands." Subarctic. Vol. 6. June Helm, Vol. Ed. Handbook of North American Indians: 146-57.

Helm, June and Eleanor Burke Leacock

1971 "The Hunting Tribes of Subarctic Canada." Eleanor Burke Leacock and Nancy Oestreich Lurie, eds. North American Indians in Historical Perspective. New York: Random House: 343-74.

Hewett, Edgar

$1922 \quad$ Art and Archaeology. Vol.13: 103-11. 
Holm, Bill and Bill Reid

ca.1975 Form and Freedom: A Dialogue on Craftsmanship and Aesthetics.

Seattle: University of Washington Press.

Jacknis, Ira

1992

"'The Artist Himself": The Salish Basketry Monograph and the Beginnings of a Boasian Paradigm." Janet C. Berlo, ed. The Early Years of Native American Art History. Seattle: University of Washington Press:134-61.

James, George Wharton

1909 Indian Basketry. New York: Dover Publications, Inc.

Jenness, Diamond

1943 "The Carrier Indians of the Bulkley River: Their Social and Religious Life." Anthropological Papers 25, Bureau of American Ethnology Bulletin 133: 577-580. Washington, D.C.

1934 "Myths of the Carrier Indians of British Columbia." The Journal of American Folk Lore 47:184-5. April-September.

Jensen, Doreen, et al.

1996 Topographies: Recent Aspects of B.C. Art. Doreen Jensen, Monika Ken Gagnon and Grant Arnold. Vancouver: Vancouver Art Gallery.

Jonaitis, Aldona

1981 "Creations of Mystics and Philosophers: The White Man's Perceptions of Northwest Coast Indian Art from the 1930s to the Present." American Indian Culture and Research Journal 5 (1): 1-45.

Kenton, Edna

1896 [1927] "The Indians of North America," Volume One, from The Jesuit Relations and Allied Documents: Travels and Explorations of the Jesuit Missionaries in New France, 1610-1791." Reuben Gold Thwaites, ed. New York: Harcourt, Brace and Company.

Kew, Michael 1993-94 "Anthropology and First Nations in British Columbia." Special Issue, B.C. Studies 100: 78-105.

Knight, Rolf 1996

Indians at Work: An Informal History of Native Labour in British Columbia, 1858-1930. Vancouver: New Star Books. 
Laforet, Andrea

1990

"Regional and Personal Style in Northwest Coast Basketry." Editor F.W.

Porter III. The Art of Native American Basketry: A Living Legacy.

Contributions to the Study of Anthropology, Number 5. New York:

Greenwood Press.: 281-98.

1984

"Tsimshian Basketry." The Tsimshian - Images of the Past: Vision for the Present. Margaret Seguin, ed. Vancouver: University of British Columbia Press: 215-80.

1982

Hats of the Northern Northwest Coast. Presented at the Ninth Annual Conference of the Canadian Ethnology Service.

n.d. (b) Basketry in British Columbia : 1778-1930. Unpublished MS.

Laforet, Andrea and Annie York

1998 Spuzzum: Fraser Canyon Histories, 1808-1939. Vancouver: UBC Press.

Lane, Kenneth S.

1952 "The Montagnais Indians, 1600-1640." Kroeber Anthropological Society Publications. Vol 7: 3.

Leacock, Eleanor Burke

1982

"Relations of Production in Band Society". Eleanor Burke Leacock and Richard Lee, eds. Politics and History in Band Societies. New York:

Cambridge University Press:159-70.

Lemert, Edwin M.

1954 "The Life and Death of an Indian State" in Human Organization. Vol.13, No.3, Fall: 23-7.

Mahoney, Irene OSU

1989 Marie of the Incarnation: Selected Writings. New York: Paulist Press.

Mason, Otis Tufton

1988 American Indian Basketry [Aboriginal Indian Basketry, 1904]. Toronto: General Publishing Co. Ltd.

1885 "Basket-Work of the North American Aborigines." Annual Report of the Smithsonian Institution for 1883-84. Washington, D.C.: Smithsonian 
Institution: 291-306.

McClellan, Catherine

1981 'Intercultural Relations and Cultural Change in the Cordillera' in Subarctic.

Vol. 6. June Helm, Vol. Ed. Handbook of North American Indians:

Washington, D.C.: Smithsonian Institution: 387-401.

McClellan, Catherine, and Glenda Denniston

1981 "Environment and Culture in the Cordillera." Subarctic. Vol. 6. June

Helm, Vol. Ed. Handbook of North American Indians, Washington, D.C.:

Smithsonian Institution: 130-45.

McLendon, Sally

1981

"Preparing Museum Collections for Use as Primary Data in Ethnographic

Research." In The Research Potential of Anthropological Museum

Collections. Anne-Marie Cantwell, James B. Griffin, and Nan A.

Rothschild, (eds.). Annals of the New York Academy of Science, 376: 20127.

McDonald, James A.

1984 "Images of the Nineteenth-Century Economy of the Tsimshian. Margaret

Seguin, Ed. In The Tsimshian - Images of the Past: Views for the Present.

Vancouver: University of British Columbia Press: 40-54.

Mead, Margaret

1959 An Anthropologist at Work; Writings of Ruth Benedict. Boston, Houghton Mifflin.

Morice, A.G., O.M.I.

$1978 \quad$ The History of the Northern Interior of British Columbia (Formerly New

Caledonia) 1660-1880. Toronto: William Briggs.

1895 "Notes Archaeological, Industrial, and Sociological on the Western Dénés with an Ethnographical Sketch of the Same." Transaction of the Canadian Institute. Vol. 4. Toronto: 1-222.

1892

"Are the Carrier Sociology and Mythology Indigenous or Exotic?". Proceedings and Transactions of the Royal Society of Canada for the Year 1892. Ser. 1, Sect. 2, Vol. 10, Ottawa:109-26.

Mulhall, David

Will to Power: The Missionary Career of Father Morice. Vancouver, 
B.C.:University of British Columbia Press.

Naylor, Maria, ed.

1975

Authentic Indian Designs: 2500 Illustrations from Reports of the Bureau of American Ethnology. New York: Dover Publications Inc., 1975.

O'Neale, Lila M.

1932 Yurok-Karok Basket Weavers. University of California Publications in American Archaeology and Ethnology 32(1):1-184.

Pulla, Siomonn 2000

From Advocacy to Ethnology: Frank Speck and the Development of Early Anthropological Projects in Canada, 1911-1920. M.A. Thesis. Ottawa, Ontario: Carleton University.

Ray, Arthur J.

1996

I Have Lived Here Since the World Began: An Illustrated History of Canada's Native People. Toronto: Lester Publishing Ltd. and Key Porter Books.

Rogers, Edward S.

1972 "The Mistassini Cree" in Hunters and Gatherers Today. M.G. Bicchieri (ed.). New York: Holt, Rinehart and Winston.

Rushing, W. Jackson 1992

"Marketing the Affinity of the Primitive and the Modern: Rene d'Harnoncourt and "Indian Art of the United States." Janet C. Berlo, ed. In The Early Years of Native American Art History: The Politics of Scholarship and Collecting. Janet C. Berlo (ed.). Seattle: University of Washington Press: 191-236.

Schevill, Margot Blum

1992 "Lila Morris O'Neale: Ethnoaesthetics and the Yurok-Karok Basket Weavers of Northwestern California.." Janet C. Berlo, ed. In The Early Years of Native American Art History: The Politics of Scholarship and Collecting. Janet C. Berlo (ed.). Seattle: University of Washington Press: $162-90$.

Smith, Derek G.

2001 "The "Policy of Aggressive Civilization" and Projects of Governance in Roman Catholic Industrial Schools for Native Peoples in Canada, 187095." Anthropologica XLIII: 253-271. 
Speck, Frank G.

ca.1941 "Art Processes in Birchbark of the River Desert Algonquin: A

Circumboreal Trait." Bureau of American Ethnology, Bulletin 128, Anthropological Papers, No. 17. Washington: Smithsonian Institution: 231-74, Plates 30-42.

1937 "Montagnais Art in Birch-Bark, a Cirumpolar Trait." Indian Notes and Monographs, Vol. XI, No.2. New York: Museum of the American Indian, Heye Foundation: 45-119, Plates I-XXI.

1935 Naspkapi: The Savage Hunters of the Labrador Peninsula. Norman: University of Oklahoma Press.

1926 "Culture Problems in Northeastern North America." Proceedings, American Philosophical Society: 272-311.

1915 "Family Hunting Territories and Social Life of Various Algonkian Bands of the Ottawa Valley." Canadian Department of Mines, Geological Survey, Memoir No. 70, Anthropological Series 8: 1-10.

Steward, Julian 1977

"Tappers and Trappers: Parallel Processes in Acculturation" in Evolution and Ecology: Essays on Social Transformation. Chicago, Illinois: University of Illinois Press: 151-79.

1960 "Carrier Acculturation: The Direct Historical Approach". Culture in History: Essays in Honour of Paul Rodin. Stanley Diamond, ed. New York: Columbia University Press: 732-44.

Steltzer, Ulli 1976

Indian Artists at Work. Vancouver: Douglas \& McIntyre.

Teit, James. A. 1906

The Lillooet Indians. New York : AMS Press.

1930

Salishan Tribes of the Western Plateaus. Franz Boas (ed.).Washington, D.C.: U.S. Government Printing Office. 
1909 The Shuswap". Franz Boas (ed.). Memoirs of the American Museum of Natural History $I V, V$, Jesup North Pacific Pacific Expedition I, IV, New York: G.E. Stechert

1900 "The Thompson Indians of British Columbia". Franz Boas (ed.). Memoirs of the American Museum of Natural History II, and Anthropology I, IV, a Jesup North Pacific Expedition, I, IV. New York: AMS Press.

The Ring

2001

Community Newspaper. Victoria, British Columbia: University of Victoria Vol. 27, No. 9.

Thornburn, Olivia

2001 “Appreciation: Mary Kawennatakie Adams, Mohawk Basket Maker and Artist," American Art. Smithsonian American Art Museum. Washington, D.C.: Smithsonian Institution. Summer, 2001: 90-5.

1999 The Pope Basket: Narrative of Subsistence to Acclamation; Mary Adams, Mohawk Basket-Maker Artist. Honours Research Paper in Anthropology, Department of Sociology and Anthropology. Ottawa: Carleton University.

1996-7 “An Ethnographic Enterprise: A Cultural Exploration of Ojibway Traditional Crafts and Contemporary Non-Figurative Art." Undergraduate Course 54.410 in Anthropology, Department of Sociology and Anthropology. Ottawa: Carleton University.

Tobey, Margaret L.

1981 "Carrier." Subarctic. Vol. 6. June Helm, Vol. Ed. Handbook of North American Indians, Washington, D.C.: Smithsonian Institution: 413-32.

Tolmie, W.F., and, G.M. Dawson

1884 Comparative Vocabularies of the Indian Tribes of British Columbia, with a Map Illustrating Distribution. Montreal: Dawson Brothers.

Trigger, Bruce $\mathrm{G}$.

1978a "Introduction." Northeast. Vol. 15. Bruce G. Trigger, Vol. Ed. Handbook of North American Indians, Washington, D.C.: Smithsonian Institution:13. 
$\overline{1978 b}$ "Cultural Unity and Diversity." Northeast. Vol. 15. Bruce G. Trigger, Vol. Ed. Handbook of North American Indians, Washington, D.C.:

Smithsonian Institution: 798-804.

Tuck, James

1978

"Regional Cultural Development, 3,000 to 300 B.C." Northeast. Vol. 15. Bruce G. Trigger, Vol. Ed. Handbook of North American Indians.

Washington, D.C.: Smithsonian Institution: 44-57.

Turner, Nancy J.

1996 "Dans une Hotte". L'importance de la vannerie das l'économie des peuples chasseurs-pêcheurs-cueilleurs du Nord-Ouest de l'Amérique du Nord; ("'Into a Basket Carried on the Back': Importance of Basketry in Foraging/Hunting/Fishing Economies in Northwestern North America.") Anthropologie et Sociétiés. Special Issue on Contemporary Ecological Anthropology. Theories, Methods and Research Fields. Montréal, Québec, 20 (3): 55-84. Personal Copy from N.J. Turner.

1992 "Just When the Wild Roses Bloom: The Legacy of a Lillooet Basket Weaver." TEKTALK: A Newsletter of Traditional Ecological Knowledge. UNESCO, World Congress for Education and Communication on Environment and Development. Vol. 1(2):5-7.

VanKirk, Sylvia

1980 "Many Tender Ties": Women in Fur-Trade Society, 1670-1870.

Winnipeg, Manitoba: Watson and Dwyer.

Whitehead, Margaret, ed.

1988 They Call Me Father: Memoirs of Father Nicholas Coccola, Margaret Whitehead. Vancouver: University of British Columbia Press.

1981 The Cariboo Mission: A History of the Oblates. Victoria, B.C.:Sono Nis Press.

Vues D"Ici

1999

Case Postale 235, Sait-Lambert, Québec, Canada, J4P 3N8. 


\section{PERSONAL COMMUNICATION}

Bergevin, Frank

2002 September 18, 2002, Frank Bergevin, Personal Communication, Hogansburg, New York. E-mail: fberge@gisco.net.

Bolton, Rena

2000 August 3, 2000, Sto:Lo Coast Salish Rena Bolton, Personal

Communication, Terrace, British Columbia.

Edgar, Kathy

2001

November 23, 2002, Ditidaht Nuu Chah Nulth Kathy Edgar, Personal

Communication. North West Native Basket Weavers Conference,

Duncan, British Columbia.

Joe, Pauline

2001

October 20, 2001, Washington State Coast Salish Pauline Joe, Personal

Communication; and, presentation at B.C. Women's History

Conference, Duncan, British Columbia.

Johnny, Alex

2000

July 29, 2000, Ts'eke Saik'uz Carrier Alex Johnny, Personal

Communication. Stony Creek Reserve, British Columbia.

Johnny, Madeline

2000 July 29, 2000, Saik'uz Ts'eke Carrier Madeline Johnny, Personal

Communication. Stony Creek Reserve, British Columbia.

Johnny, Stella

2001

November 23, 2001, Cowichan Coast Salish Stella Johnny, Personal

Communication. Northwest Native Basket Weavers Conference, Duncan, British Columbia.

Laforet, Andrea

1998 November 12, 1998, Dr. Andrea Laforet, Personal Communication,

Director, Canadian Ethnology Service, Canadian Museum of Civilization, Hull, Quebec.

Longman, Mary

$2001 \quad$ November 1, 2001, Gordon Saulteaux Mary Aski-Piyesiwiskwew

Longman, Personal Communication. Victoria, British Columbia. 
McKenzie, Ward

2000

August 1, 2000, Ward McKenzie, Personal Communication. Hazelton, British Columbia.

McQuary, Bernie

2000

July 30, 2000, Nadleh Whuten Carrier Bernie McQuary, Personal

Communication. Nautley Reserve, British Columbia.

Mould, Laurel

2000

August 1, 2000, Laurel Mould, Executive Director, Personal

Communication. K'san Historical Village, Hazelton, British Columbia.

Thomas, Mary

2001

April 25, 2001, Neskonlith Secwepemec Interior Salish Mary Thomas, Personal Communication. Salmon Arm, British Columbia.

www.http://rbcm 1/rbcm.gov.bc.ca

2000

"Website Map", Royal British Columbia Museum, Victoria, British

Columbia. Februa 